\title{
A social, literary and musical study of Julie Pinel's \\ Nouveau recueil d'airs sérieux et à boire (Paris, 1737)
}

by

\section{Corisha Brain}

\section{VOLUME ONE}

A thesis

submitted in fulfilment of the requirements for the degree of Master of Music in Musicology

New Zealand School of Music

May 2008 


\section{A social, literary and musical study of Julie Pinel's \\ Nouveau recueil d'airs sérieux et à boire (Paris, 1737)}

by

\section{Corisha Brain}

\section{VOLUME TWO}

A thesis

submitted in fulfilment of the requirements for the degree of Master of Music in Musicology

New Zealand School of Music

May 2008 


\begin{abstract}
This thesis discusses the life and work of the eighteenth-century French composer, Julie Pinel. Pinel's extant music comprises one collection of music, Nouveau recueil d'airs sérieux et à boire à une et deux voix, de Brunettes à 2 dessus, scène pastorale, et cantatille avec accompagnement, published in 1737, of which a critical edition has been produced in volume II of this thesis. There is little information regarding Pinel's life and work, however, the preface and privilège included in her Nouveau recueil provide some clues as to Pinel's biography. Her life and music are examined, with reference to the social, literary and musical environment she was working in. An added dimension is that Pinel was working as a professional musicienne at a time when women were beginning to find their voice and place in professional society. Pinel claims authorship of the majority of the poems in her collection, and the rest come from anonymous sources. Pinel's literary and musical output illustrates her obvious knowledge of the current trends in eighteenth-century France, with most of her poetry written for a female poetic voice, displaying many of the fashionable themes of the day. Her music displays a variety of styles, ranging from simple airs in binary form, traditionally found in most French airs sérieux et à boire, to the operatic, and the fashionable rococo styles.
\end{abstract}




\section{Acknowledgements}

Firstly, I wish to thank my supervisor, Dr Greer Garden, who introduced me to Julie Pinel, providing me with a unique and interesting research topic, helped with some of the translations, and whose guidance, advice, and counsel have been invaluable during the course of this research.

There are many other people who have been very important, and in particular I would like to thank a fellow Master's student, Felicity Smith, who helped me tackle Sibelius and whose support, advice and company motivated me throughout. Many thanks go to the Student Services staff at 14 Kelburn Parade where I have worked part-time, who have been incredibly supportive, allowing me flexible work hours especially during the final stages of my study. I would also like to thank Douglas Mews and all the proof-readers who generously gave their time to look over excerpts of my work and provide feedback.

Most importantly, with love I thank my parents for their constant encouragement and support, and especially for their financial help, without which, this study would not have come to fruition. 


\section{VOLUME 1}

\section{Contents}

CHAPTER 1 The life of Julie Pinel …............................................................. 1

CHAPTER 2 Pinel's patron: Charles de Rohan, Prince de Soubise....................... 8

CHAPTER 3 Eighteenth-century Parisian Society: Salon culture, the French air, and the burgeoning Italian influence................................................................. 15

CHAPTER 4 Women musiciennes in eighteenth-century France .......................... 26

CHAPTER 5 The Poetry in Pinel's Nouveau recueil ............................................. 34

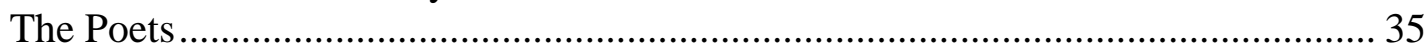

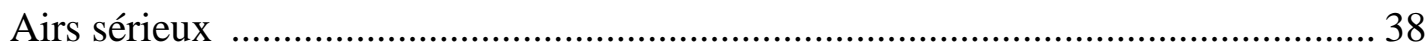

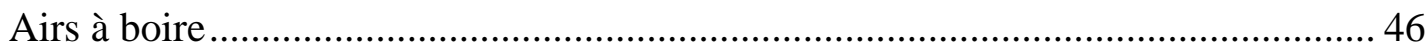

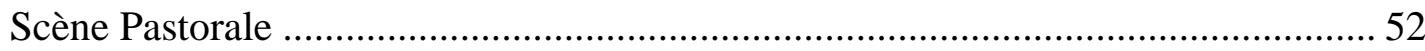

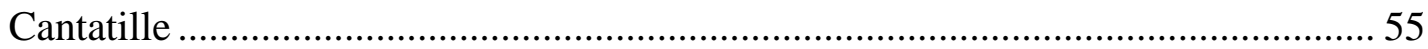

CHAPTER 6 The Music in Pinel's Nouveau recueil ............................................ 59

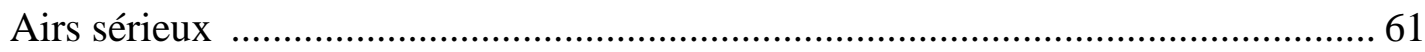

The work of Pinel and René Drouard de Bousset compared ................................. 72

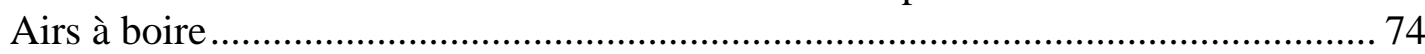

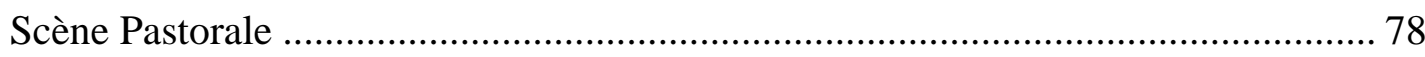

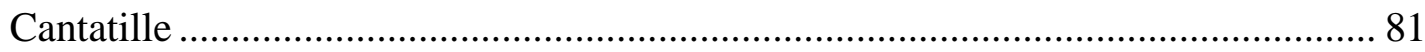

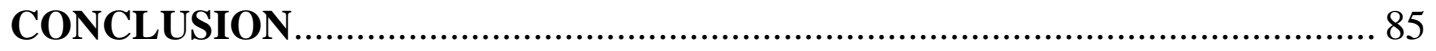

APPENDIX 1 Catalogue of Julie Pinel's Nouveau recueil d'airs sérieux et à boire à une et deux voix, de Brunettes à 2 dessus, scène pastorale, et cantatille avec accompagnement (1737)......

APPENDIX 2 Chart of Voltaire's correspondence listing each reference to Charles de Rohan, Prince de Soubise.....

APPENDIX 3 René Drouard de Bousset's air, 'Lors que l’on boit à mes amours (1731) 


\section{VOLUME 2}

\section{Contents}

Julie Pinel, Nouveau recueil d'airs sérieux et à boire à une et deux voix, de Brunettes à 2 dessus, scène pastorale, et cantatille avec accompagnement (1737).

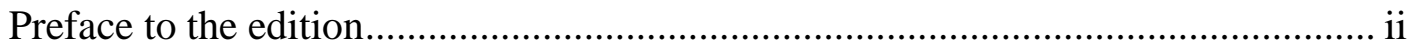

Facsimile of the title page from the 1737 edition ................................................... iii

Facsimile of the first page of the cantatille in the 1737 edition............................... iv

Partial translation of Pinel's 1736 Privilège Général ............................................... v

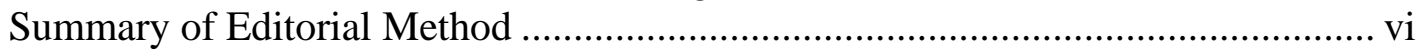

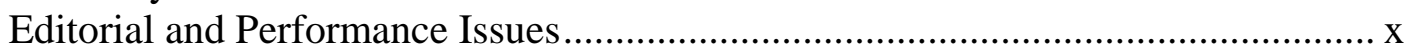

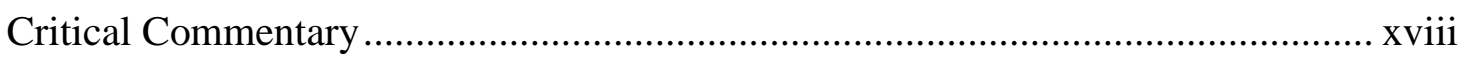

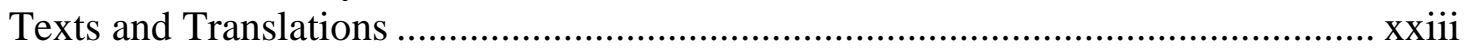

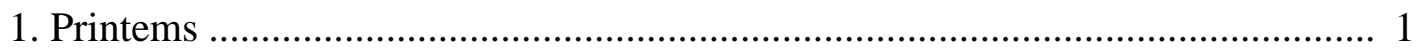

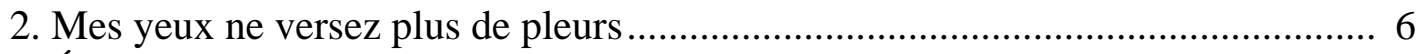

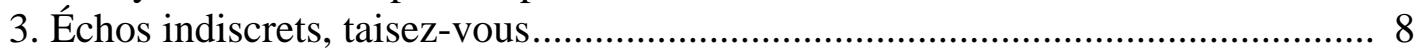

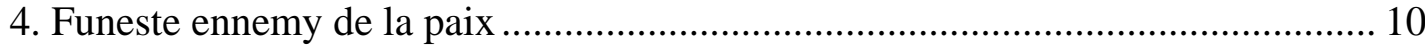

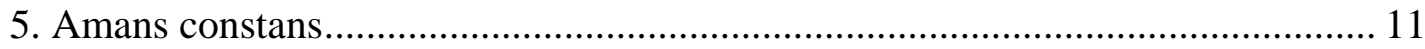

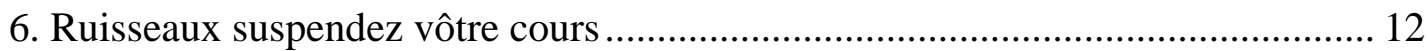

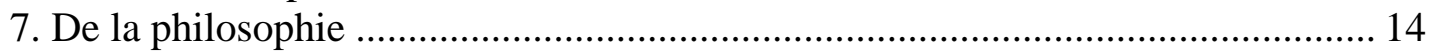

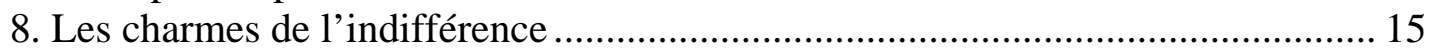

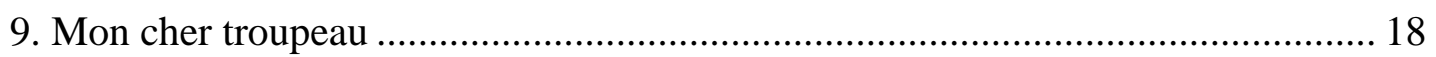

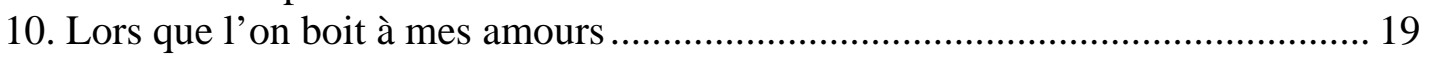

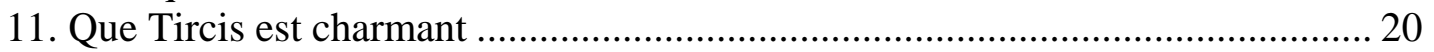

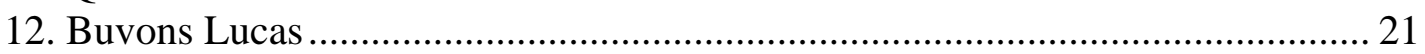

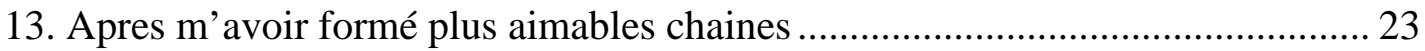

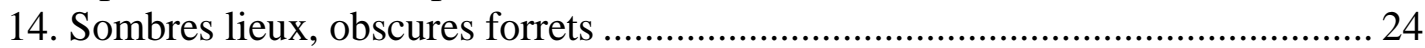

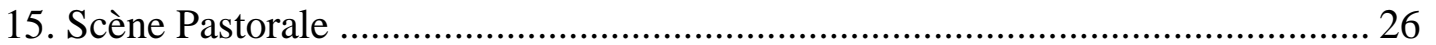

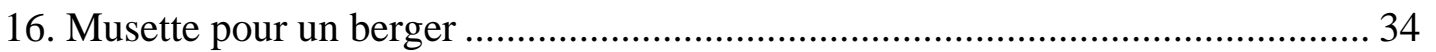

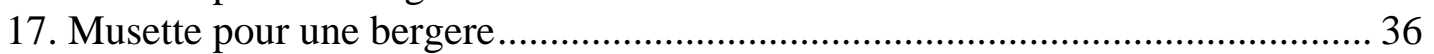

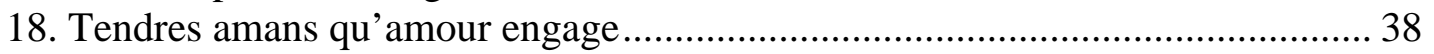

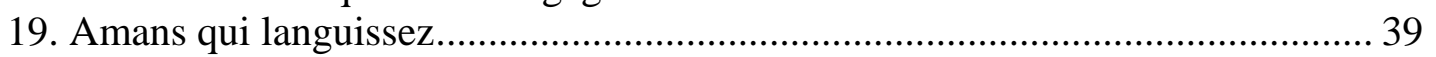

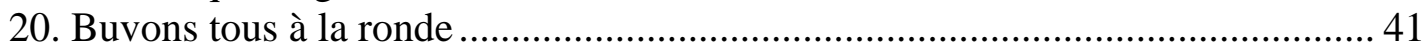

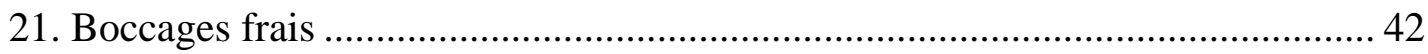

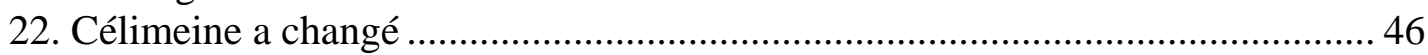

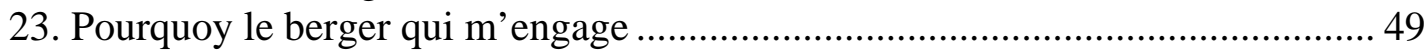

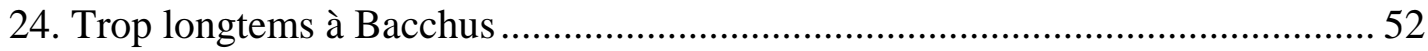

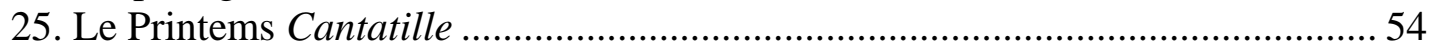

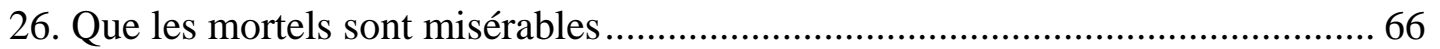

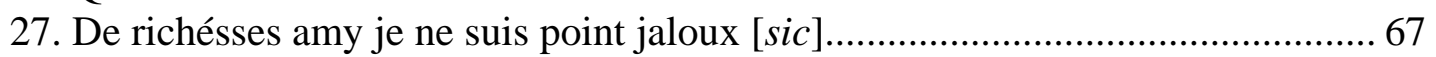

28. Pour guérir sans retour la plus vive bléssure [sic] .............................................. 69

29. Dieu du vin quelle est donc ta fatalle puissance ............................................ 70

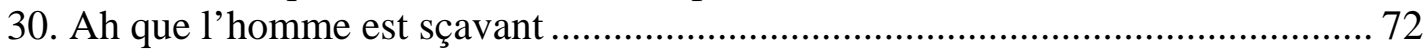

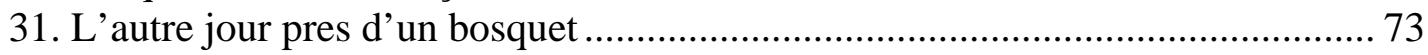




\section{List of Tables and Examples}

\section{Image}

Image 1 Charles de Rohan, Prince de Soubise

\section{Tables}

Figure 1 Distribution of women's roles in music, 1715-1789 ...............................32

Figure 2 Chart of air type and author of each piece in Pinel's Nouveau recueil .......36

Figure 3 Airs with a male poetic voice ................................................................37

Figure 4 Chart of line lengths found in Pinel's airs sérieux ...................................38

Figure 5 Chart of line lengths found in Pinel's airs à boire ....................................46

Figure 6 Chart of line lengths found in Pinel's Scène pastorale ...............................53

Figure 7 Chart of line lengths found in Pinel's cantatille .........................................56

Figure 8 Julie Pinel's Nouveau recueil d'airs sérieux et à boire (1737) ...................59

Figure 9 Overview of Pinel's Nouveau recueil.........................................................60

Figure 10 Comparison of harmony in two epigrammatic airs ...............................63

\section{Musical examples}

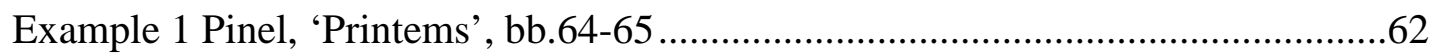

Example 2 Pinel, 'Echos indiscrets, taisez vous’, bb. 7-8 ..................................67

Example 3 Pinel, 'Echos indiscrets, taisez vous’, bb. 16-17 .................................67

Example 4 Pinel, 'Funeste ennemy de la paix’, bb.10-11 .....................................67

Example 5 Pinel, ‘Apres m’avoir formé', bb.3-4 …............................................67

Example 6 Pinel, 'Les charmes de l'indifférence', bb.14-15 .................................68

Example 7 Pinel, 'Printems', bb.32-33 ......................................................................68

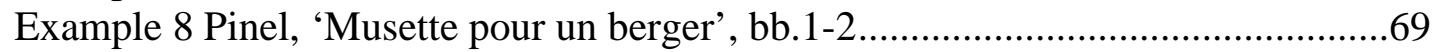

Example 9 Pinel, 'Parodie du premier couplet', b.6 ...................................................69

Example 10 Pinel, 'Musette pour une bergere', bb.5-9 ...........................................70

Example 11 Pinel, ‘Pourquoy le berger qui m’engage', strophe 1, bb. 14-15...........71

Example 12 Pinel, 'Pourquoy le berger qui m’engage', strophe 2, bb. 11-13...........71

Example 13 Pinel, 'Pourquoy le berger qui m’engage’, strophe 3, bb. 12-15...........72

Example 14 Bousset, 'Lors que l'on boit à mes amours', bb.11-15 ..........................73

Example 15 Pinel, 'Lors que l'on boit à mes amours', bb.9-14 ...............................73

Example 16 Pinel, ‘Lors que l’on boit à mes amours', bb. 1-3 .................................73

Example 17 Pinel, 'Ah que l'homme est sçavant', bb. 35-36.....................................75

Example 18 Pinel, ‘Ah que l'homme est sçavant', bb. 47-48..................................75

Example 19 Pinel, ‘Buvons tous à la ronde’, bb.1-3 ...............................................77

Example 20 Pinel, 'Scène Pastorale', bb. 43-44 ............................................................79

Example 21 Pinel, 'Scène Pastorale', bb. 76-77 .......................................................79

Example 22 Pinel, 'Scène Pastorale', bb.119-122 ......................................................80

Example 23 Pinel, ‘Scène Pastorale’, duo, bb.23-26 .................................................81

Example 24 Pinel, 'Le Printems', recitative 1, bb.1-5.............................................82

Example 25 Pinel, ‘Le Printems’, recitative 2, bb.9-13............................................82

Example 26 Pinel, ‘Le Printems’, air, bb. 9-16 ....................................................83

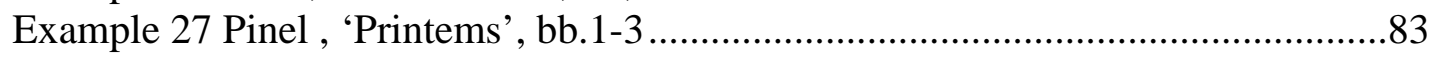

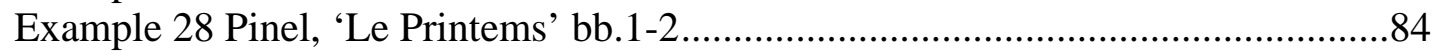




\section{Chapter 1}

\section{The life of Julie Pinel}

On the whole, the life of eighteenth-century composer Julie Pinel remains a mystery. We have no dates for Julie Pinel, and very little information pertaining to her biography. The fragments of information we do have, have enabled some assumptions to be made but have also raised numerous questions. Julie Anne Sadie's entry on Julie Pinel in Grove estimates her date of birth as $1710 .^{1}$ As we examine subsequently this information, we will return to this date and ascertain its possibility.

At the end of 1736, Pinel obtained an eight-year privilege allowing her to publish 'collections of airs, cantatas and other pieces of vocal and instrumental music of her composition'. ${ }^{2}$ Almost immediately, she published a collection of songs in the form of a book of airs, Nouveau recueil d'airs sérieux et à boire à une et deux voix, de Brunettes à 2 dessus, scène pastorale, et cantatille avec accompagnement (1737). Pinel's verified extant music consists only of this 1737 collection, which she dedicates to the Prince de Soubise, explaining that the Pinel family had served the Soubise house since the 1680s: 'C'est le sort de ma famille, depuis plus de cinquante cinq ans, d'être attachée à votre Illustre Maison. ${ }^{3}$ While we have some information regarding both Pinel and the Prince de Soubise, there is nothing, save this preface, that links the two figures to substantiate Pinel's statement. In spite of this, the preface, alongside our existing knowledge on patronage in eighteenth-century France, provides enough evidence for us to fill in some gaps and theorise as to Pinel's biography and family circumstances.

\footnotetext{
${ }^{1}$ Julie Anne Sadie, 'Pinel, Julie’, Grove Music Online ed. L. Macy (Accessed 25 January 2008), http:www.grovemusic.com.

${ }^{2}$ For the complete privilege, see page v, Volume 2.

3 'It has been the destiny of my family, for more than 55 years, to have been attached to your illustrious house.' Julie Pinel, Nouveau recueil d'airs sérieux et à boire (Paris: Veuve Boivin, Le Clerc, 1737). The preface is given in full later in this chapter.
} 
Fortunately, the name 'Pinel' appears in other sources in the seventeenth and eighteenth centuries. There were several musicians of this name, however, until the late twentieth century they were often confused as being one person. ${ }^{4}$ This stems from the differing spellings of the name: Pinel and Pinet. One case in point appears in a letter of nomination which was written on January $7^{\text {th }} 1656$ :

Le Roy...considérant la perfection que Germain Pinet s'est acquise à toucher du luth, et qui avait donné sujet à S. M. de la choisir pour lui en montrer la méthode, le plaisir de l'entendre et l'estime qu'elle a pour lui, ayant depuis lors considéré qu'il lui était nécessaire pour le divertir en particulier et pour remplir les concerts de la musique de la chambre, S. M. a retenu et retient le dit sieur Pinet, pour son joueur de luth et de théorbe, et pour le server désormais avec l'un et l'autre de ces instruments, tant dans les concerts de la musique de sa chamber, que dans ses récréations particulières... 5

Germain Pinel (b early 1600s; d Paris October 1661) was a master lutenist, theorbist and composer appointed as the lute teacher to the young Louis XIV before entering la musique de la chambre in 1656 as a lutenist and theorbist. We do not know why Germain's name does not appear in the list of chamber musicians from 1664 onwards but one explanation for this was the succession of his son, Séraphin Pinel, to the position of ordinaire de la musique de la chambre, which Germain had previously held. ${ }^{6}$ Herein lies the source of some confusion because L'Etat de la France ${ }^{7}$ never actually named Séraphin, and continued to name Germain until $1679 .{ }^{8}$ To compound the already confusing situation, there appears a third musician with the Pinel name: François Pinel, who is listed in L'Etat de la France as 'haute-taille ordinaire \& Joueur de Théorbe/Chambre;

\footnotetext{
${ }^{4}$ Echorcheville equates 'Pinet' and 'Pinel'. Jules Ecorcheville, Vingt suites d'orchestre du XVIIe siècle français (New York: Broude, 1970), 2:13. Ecorcheville (1872-1914) was a musicologist and pupil of César Franck and H. Riemann who worked on the Catalogue de la musique ancienne de la Bibliothèque nationale which contained collections of music prior to 1750 . François Lesure; Frayda B. Lindemann, 'The Music Department of the Bibliothèque Nationale, Paris', Notes, $2^{\text {nd }}$ Ser., 35/2 (Dec., 1978), p.254.

${ }^{5}$ The King...considering the perfection that Germain Pinet achieved playing the lute, and which caused [Sa Majesté] to choose him as a teacher, the pleasure of hearing him and the esteem which he has for him, having since considered that it was necessary that he was needed for his private entertainment in particular and to fill the concerts of the music of the chamber, [Sa Majesté] reserved and retains said Mr Pinet, for his lute and theorbo playing, and to serve from then on with one or the other of these instruments, in the concerts of the music of his chamber, in his private entertainment... Arch. nat. O ${ }^{1}$ 7. fo 155 as cited in Ecorcheville, 1970, 2:13-4.

${ }^{6}$ Ecorcheville, 1970, 2:14.

7 L'Etat de la France is a publication providing information on the hundreds of singers, instrumentalists, composers and dancers who served the royal court. Albert Cohen, 'L'Etat de la France: One Hundred Years of Music at the French Court', Notes 48/3, March, 1992, p.775 \& 801.

${ }^{8}$ Germain Pinel died in 1661, which indicates conclusively that the Pinel being named was someone else, and Cohen believes it to be Séraphin Pinel.
} 
1692, 1694, 1697, 1698, 1699, 1702, 1708.9 He was best known as an instrumentalist. His name appears in L'Etat for many years despite him having passed his post as ordinaire de la musique du roi to Laurent Dupré in 1671. ${ }^{10}$ François Pinel was the younger brother of Germain by approximately twenty years, ${ }^{11}$ and he apparently had a daughter by the name of Françoise: 'Il possède déjà une telle notoriété qu'il a pu choisir Lully comme parrain de sa fille Françoise'. ${ }^{12}$

Lully's 1656 Ballet de Psyché is another source of information on the Pinel musicians establishing that they were in fact one family: '...trois musiciens venus en ces lieux charmer le sens de l'ouïe, les Srs Pinelle père, fils et frère. ${ }^{13}$ Clearly these are Germain, Séraphin and François. Germain is also named in Lully's 1657 Ballet de l'Amour malade and in his 1659 Ballet de la Raillerie, ${ }^{14}$ which, along with his own output of music cements his status as the most famous Pinel musician. ${ }^{15}$ This of course brings us to the musician who lies at the centre of the current study: Julie Pinel.

\footnotetext{
${ }^{9}$ François Pinel replaced a father and son duo by the name 'Tissu' who were 'taille' singers in the chamber and the chapel, as well as performers and teachers of the lute. François fits a similar description, being described as a 'chanteur' and 'théorbe ordinaire de la chambre'. Ecorcheville, 1970, 2:14.

${ }^{10}$ Ecorcheville suggests that Dupré died in 1680 which is why the Pinel name persists for so long. It is unclear who succeeded François after this, however, both Ecorcheville and Vendrix (Grove) suggest that it was Robert de Visée. Philippe Vendrix, 'Dupré', Grove Music Online ed. L. Macy (Accessed 3 April 2008), http://www.grovemusic.com.

${ }^{11}$ Monique Rollin \& Jean-Michel Vaccaro, Oeuvres de Pinel: Edition et transcription (Paris: CNRS, 1982), p.xiv.

12 'He already has such notability that he could choose Lully as the godfather of his daughter Françoise.' B.N., Fichier, Thoinan, document cited without call mark in Rollin and Vaccaro, 1982, p.xiv. Within the scope of this study, it was unfortunately not possible to examine this document which may provide information as to whether François Pinel had other children.

13 '...three musicians come to this place to charm the sense of hearing, Srs Pinelle father, son and brother.' Ballard, 1656, in- $4^{\circ}$ as cited in Ecorcheville, 1970, 2: 14-15. There is no indication of where exactly this information is written in the Ballet de Psyché, and once again it was not possible to examine this document during this study.

${ }^{14}$ Ballet de l'Amour malade, dansé par Sa Majesté le 17 janvier 1657 dans la grande salle du Louvre. Livret de F. Buti. Vers de Benserade, Musique de Lully, Pinel participe au ballet, entre autres à la première entrée. (Ballet de l'Amour malade danced by his majesty on 17 January 1657 in the great Louvre. Libretto by F. Buti. Verse by Benserade, music by Lully. Pinel participated in the ballet's premiere performance). Bibl. De l'Opéra, Ms. Thoinan, p.397 cited in Rollin \& Vaccaro, p.xii. Ballet de la Raillerie, dansé par Sa Majesté le 19 février 1659. Vers de Benserade, Musique de Lully, J.-B. Boësset. Pinel et Pinel le jeune participent au ballet...à la 1re entrée. (Ballet de la Raillerie danced by his majesty on 19 February 1659. Vers by Benserade, music by Lully, J-B. Boësset. Pinel and the younger Pinel participated in the ballet's first performance). Bibl. De l'Opéra, Ms. Thoinan, p.409 cited in Rollin \& Vaccaro,1982, p.xii.

${ }^{15}$ Germain composed 78 dances, 8 préludes non mesurés for lute, and one prélude non mesuré for theorbo (ed. M. Rollin and J.-M. Vaccaro, Paris, 1982). David Ledbetter, 'Pinel, Germain',
} 
A clue as to Julie Pinel's circumstances may be found in the dedicatory preface of her book of airs. The preface is addressed to 'Monseigneur le Prince de Soubize, Captaine Lieutenant des Gensdarmes de la garde Du Roy. ${ }^{, 16}$ Pinel is referring to Charles de Rohan, Prince de Soubise (b. Versailles July 16, 1715-d. July 4, 1787) who will be discussed in detail in Chapter two:

C'est le sort de ma famille, depuis plus de cinquante cinq ans, d'être attachée a votre Illustre Maison, dans laquelle, j'ay pour ainsy dire, reçeu la lumiere, c'est ce qui semble autoriser la liberté que je prends, de vous offrir le premier ouvrage, que je mets au jour, votre auguste nom, à la teste de ce livre, suffit, pour le render recommandable, quell Bonheur pour moy Monseigneur si quelques unes des arriettes dont il est remply, peut se trouver digne de vous amuser quelques instans, j'ose esperer que mon zêle et l'ardeur de vous plaire, me tiendront lieu de merite aupres de vous, daignez Monseigneur, vous rendre le protecteur de ma muse et des productions qu'elle fait gloire de vous consacrer un livre de Cantates sera dans peu de tems le second homage quelle s'appreste a vous rendre, faites moy la grace de les recevoir l'un et l'autre, comme une preuve de l'attachement inviolable, et du profond respect avec lesquels j'ay l'honneur d'être, Monseigneur! Votre tres humble et tres obeissante servante, Julie Pinel. ${ }^{17}$

She is certainly grateful for Rohan's patronage. Her flowery dedication implies that Rohan must have played a vital role in her establishment as a musician, and her intention to publish a book of cantatas also makes it clear that Rohan's approval was worth striving for.

Julie Anne Sadie identifies her as a 'member of the Pinel dynasty of court lutenists', ${ }^{18}$ which is extremely likely, yet not definite. Julie Pinel probably followed the path of her family members in having a musical career, as happened in the case of Séraphin Pinel. Musical careers were established through family succession, for it was expected that children would succeed their parents in

Grove Music Online ed. L. Macy (Accessed 3 April 2008), http://www.grovemusic.com Ecorcheville also tentatively attributes a Courante to Germain Pinel from a manuscript in Cassel and lists the sources containing the œuvres of Pinel: Ecorcheville,1970, 2: 15.

${ }_{16}$ Monseigneur the Prince of Soubize, Captain Lieutenant of the Police and the Royal guard.

${ }^{17}$ It has been the destiny of my family, for more than 55 years, to have been attached to your illustrious house, in which I have, so to speak, received the light of day [education], and it is this that seems to authorise the liberty that I am taking to offer you the first work that I am publishing. Your noble name, at the start of this book, suffices to render it recommendable. What happiness it will give me Monseigneur if some of these arriettes of which it [the book] is full can amuse you for a few instants. I dare to hope that my diligence, zealousness and ardent desire of pleasing you will take the place of merit in your high esteem. Deign, Monseigneur to render yourself the protector of the productions that my muse glories in presenting to you. A book of Cantates, in a short while, will be the second tribute which is about to be rendered to you. Do me the gracious honour of receiving both of them, as proof of the inviolable attachment and profound respect with which I have the honour of being,

Monseigneur

Your very humble and very obedient servant, Julie Pinel.

${ }^{18}$ Julie Anne Sadie, 'Pinel, Julie', Grove Music Online ed. L. Macy (Accessed 25 January 2008), http:www.grovemusic.com. 
employment. Simply by looking through the list of musicians in L'Etat de la France, one can see how many families of musicians existed. ${ }^{19}$ This is likely to be the case with Julie Pinel, even though there is no mention of her name in any sources on the Pinel family and we are not sure where exactly she fits in. She may have been related to François Pinel who died in $1709 .^{20}$

Julie Pinel is listed in several sources as the composer of a tragédie-opéra in five acts with the title 'Appollonius'. ${ }^{21}$ One of these references is found in a catalogue entry by Boisgelou (1734-1806): ${ }^{22}$

Je l'ay vû dans ma jeunesse, Elle étoit alors fort vieille (ce il y a longtemps) elle montroit à jouer du Claveçin, je lui ay ouï dire qu'elle avoit composé un Opéra, il n’a été ny joué, ny imprimé, et vraisemblablement il ne méritoit pas de l'être. NB On trouve dans un Vieux Recueil Manuscrit de Pièces. Tombeau du Roy d'Angleterre, composée par le Sr Pinel. ${ }^{23}$

Paul-Louis Roualle de Boisgelou was a music cataloguer in the music department at la Bibliothèque nationale, Paris; ${ }^{24}$ his note dates from 1800. Whether this was a proper meeting or not cannot be substantiated, however, it is interesting that Boisgelou claims that Pinel's opera was never played or published, and it did not deserve to be. Pinel's composition of an opera is a less remarkable achievement than it may seem at first sight. A number of other French women also succeeded in writing operas in the late seventeenth and early eighteenth centuries, and had them performed as well. Pinel's predecessors

\footnotetext{
${ }^{19}$ Cohen, 1992, p.775.

${ }^{20}$ Julie Anne Sadie suggests this connection in a footnote in her chapter on women musicians. Sadie, 1986, p.221.

${ }^{21}$ The first mention of this opera is by Guillaume Debure \& Joseph Basile Bernard van Praet, Catalogue des Livres de sa Bibliothéque de feu M. le duc de la Vallière (Paris, CL. J. Bap. Bauche, 1760, p.471; The second is in a catalogue entry by Boisgelou [Paul-Louis Roualle de] in Table biographique des auteurs et compositeurs de musique dont les ouvrages sont à la Bibl[iothèque] nationale. Ms. Autogr., ca. 1800 [no page number]; and it is listed in Charles-M. de la Roncière, Département des manuscrits, Bibliothèque nationale, Catalogue général des manuscrits français (France: E. Leroux, 1902), p.326. I am grateful to Associate Professor Robert Hoskins who pursued this question further and addressed the issue with Mme Catherine Massip, conservateur and director of the department of music at the Bibliothèque nationale. Mme Massip found no mention of the opera in the current Bibliothèque nationale and Conservatoire files, Aresnal, Opera, or Versailles catalogue.

${ }^{22}$ Boisgelou's dates are found in an article cited by Denise Launay, 'Lebeau, Élisabeth - Un Collaborateur bénévole de la Bibliothèque nationale à la fin du XVIII siècle, Paul-Louis Roualle de Boisgelou, 1734-1806', Bulletin d'Information de l A. B. F., 27 Nov. 1958.

${ }^{23}$ 'I saw her when I was young, She was then very old (this was a long time ago); She taught the harpsichord; I have heard tell of her that she had composed an opera, it has neither been performed nor published, and in all likelihood it does not deserve to be. NB. We find a piece entitled Le Tombeau du Roy d'Angleterre in 'Vieux Recueil Manuscrit de Pièces', composed by Sr Pinel.' Boisgelou, 1800.

${ }^{24}$ Lesure \& Lindemann, 1978, p.252.
} 
included Elisabeth-Claude Jacquet de La Guerre ${ }^{25}$ whose tragédie en musique, Céphale et Procris, was published and performed by the Académie Royale de Musique in $1694 .^{26}$ Hers was the first by a woman to be performed at the Paris Opéra. ${ }^{27}$ Mademoiselle Duval (1718-1775) followed Jacquet de La Guerre’s lead, with her ballet-opera Les Génies, ou Les caractères de l'Amour performed at the Paris Opéra in $1736 .^{28}$

If Pinel's contemporaries seemed not to judge her adept in the composition of opera, then she was surely more recognised for her talent as a performer if we go by Boisgelou's account of her teaching the harpischord, a favoured instrument and common pursuit for young French women during the ancien régime. ${ }^{29}$ Teachers were generally performers also, and Pinel was clearly sought after and known as a teacher. Furthermore, Pinel enjoyed the prestige of having her own dedicated collection of airs published by La Veuve Boivin and Le Clerc in Paris, ${ }^{30}$ which confirms her talents as a composer. Pinel was obviously aware of the latest vogues and styles in French music. The inclusion of a scène pastorale and a cantatille in her Nouveau recueil are indicative of this. As a recognised

\footnotetext{
25 Jacquet de La Guerre will be discussed further in Chapter 4 on women musiciennes in eighteenth-century France.

${ }^{26}$ Mary Cyr (ed.), Elisabeth-Claude Jacquet de La Guerre: The Collected Works Vol. 4 (New York: The Broude Trust, 2005), p.xiii.

${ }^{27}$ Catherine Cessac, Elisabeth Jacquet de La Guerre : une femme compositeur sous le regne de Louis XIV (Arles : Actes sud, 1995), p.80.

${ }^{28}$ James R. Anthony, 'Duval, Mlle', Grove Music Online ed. L. Macy (Accessed 2 February 2008), http:www.grovemusic.com; it was not until 1784 that the next opera composed by a female was performed: 'acte de ballet Tibulle et Délie, ou Les Saturnales' by Henriette de Beaumesnil (1748-1813). Elisabeth Cook, 'Henriette Adélaïde Villard de Beaumesnil', Grove Music Online ed. L. Macy (Accessed 2 February 2008), http:www.grovemusic.com.

${ }^{29}$ Sadie, 1986, p.202.

30 Elizabeth Catherine Ballard, the daughter of Jean-Baptiste-Christophe Ballard (1663-1750), married French music seller and publisher, François Boivin (1693-1733) in 1724 and began assisting him. Boivin bought the shop La Règle d'Or, previously owned since 1715 by Henry Foucault. With his uncle, Michel Pignolet de Montéclair, Boivin went into business to sell and print music. On his death in 1733, Elizabeth took over the management of their shop under the name La Veuve Boivin, during which time the business experienced immense success and a growth in sales. Sylvette Milliot, 'Boivin, François', Grove Music Online ed. L. Macy (Accessed 2 February 2008), http:www.grovemusic.com; Sylvette Milliot, 'The Boivins: a pair of $18^{\text {th }}$ century music dealers', Revue de musicologie, Vol. 54, no. 1, 1968, p.106. Jean-Pantaléon Le Clerc (before 1697-after 1759) was a French publisher and violinist who lived at the Croix d'Or, rue de Roule in Paris. At the time of Pinel's publication in 1737, Le Clerc was associated with Boivin on the title pages of works, an example of which can be seen on the front page of Pinel's recueil. Anik Devriès, 'Le Clerc, Jean- Pantaléon', Grove Music Online ed. L. Macy (Accessed 3 April 2008), http:www.grovemusic.com.
} 
performer, composer and teacher, Pinel would have been a well-respected member of the bourgeoisie.

Pinel may have composed most of the airs in this collection at an earlier time than 1737 for several reasons. The immediacy with which she produced a collection of music after obtaining a privilege is notable, and coupled with what is an interesting title for her collection, gives us reason to doubt that she composed all of her work in or near 1737. As Laury Gutiérrez states, the title of Pinel's collection is unusual, given the publication date. ${ }^{31}$ The terms 'Nouveau' and 'Recueil d'airs sérieux et à boire' were by now outdated, with Ballard preferring the title chansons choisies for his collections. ${ }^{32}$ On the other hand, the inclusion of a cantatille in Pinel's collection would suggest otherwise. It was when the popularity of the cantate française began to diminish that a shorter version of the cantata was born in the cantatille. Julien Tiersot places the beginning of decline of the cantata in the late 1720s at the same time that the cantatille appeared. ${ }^{33}$ Unless Pinel was at the forefront of the developing style and forms in French music at the time, it is unlikely that she would have composed Le Printems before 1728, at the earliest.

Like the other Pinel musicians, it is likely that Julie Pinel's name was spelt mistakenly on occasion, and that she was referred to in different manners. There is an air attributed to 'Pinet la fille' in a 1710 publication of Recueil d'airs sérieux et à boire as well as an air in the 1720 publication by 'Melle. P.' 34 If these works are in fact products of Julie Pinel, her date of birth may have been earlier than that given by Sadie. Maybe Pinel was a musically gifted child which could explain the 1710 air by 'Pinet la fille'. As Boisgelou lived from 17341806, his description of Pinel as 'étoit alors fort vieille’ when he was in his youth is further evidence that she was born in the late seventeenth century.

\footnotetext{
${ }^{31}$ Laury Gutiérrez, The Pleasures of Love and Libation: Airs by Julie Pinel and other Parisian women (La Donna Musicale - LA 07103: Boston, 2007), p.14.

${ }^{32}$ Gutiérrez, 2007, p.14.

33 Julien Tiersot, 'Cantates de XVIIIe Siècle', Le Ménestrel, LXIX (1893), p.142 as cited in Vollen, Gene E., A French cantata: A Survey and Thematic Catalog (Ann Arbor, Mich.: UMI Research Press, 1982), p.16.

${ }^{34}$ Gutiérrez, 2007, p.14.
} 


\section{Chapter 2}

\section{Pinel's patron: Charles de Rohan, Prince de Soubise}

Over the course of the eighteenth century, the dependence of artists on patronage began to decrease and it became more possible to earn a living independently. ${ }^{1}$ In the past, patronage had provided artists with an essential income to supplement the payments received from publishers. Louis XIV was one such important patron and many of the wealthy bourgeois also patronised writers and musicians as part of their attempt to mix with the elite. ${ }^{2}$

As was highlighted in the previous chapter, Julie Pinel dedicated her collection to Charles de Rohan, Prince de Soubise. The Rohan family can be classified as princes $d u$ sang (princes of the blood) having secured the rank of prince in the sixteenth century as a result of their claim to be descendants from the sovereign dukes of Brittany. ${ }^{3}$ Furthermore, Charles de Rohan, Prince de Soubise is identified as such in a brief mention in Colin Jones' book, The Great Nation. ${ }^{4}$

\footnotetext{
${ }^{1}$ John Lough, An Introduction to Eighteenth Century France (London: Longmans, 1960), p.231.

2 John Lough, An Introduction to Seventeenth-Century France (London: Longmans, 1957), p.181.

3 François R. Velde, 'The Rank/Title of Prince in France', Heraldica, available from http://www.heraldica.org/topics/france/frprince.htm, accessed 18 August, 2007. There are references to Jean Rohan, vicomte de, as being a noble of the duchy and a Breton who served Charles de Blois (duke of Brittany from 1341). Michael Jones, Ducal Brittany 1364-1399 (London: Oxford U.P., 1970), pp.32 \& 57-8. The princes of the blood played an important role as literary patrons. Lough, 1960, p.257. In ancien régime France, the term prince referred to one's rank or title. Prince derives from the Classical Latin term princeps meaning 'first in order'. Jonathon D. Boulton \& William Kibler (eds.), Medieval France: An Encyclopedia (New York: Garland Pub., 1995), p.759. In fifteenth century France, the term was used in two groupings: princes du sang (princes of the blood) and princes étrangers (foreign princes): 'Princes du sang et légitimés sont membres de la famille royale, et les princes étrangers voisinent avec les ducs.' (Princes of the blood and those declared legitimate are members of the royal family, and foreign princes are close to dukes). Jean-François Solnon, 'Princes', François Bluche (ed.), Dictionnaire du grand siécle (Paris: Fayard, 1990), p.1255. Princes du sang were those who were in line for the royal throne, whereas princes étrangers indicated foreigners who had been admitted to the court by the French king. It was during the sixteenth century when the term prince became understood as it is today, 'member of the lineage of a sovereign lord.' Boulton \& Kibler, 1995, p.759.

4 M. Bordes, La Réforme municipale du contrôleur-général Laverdy et son application (Toulouse, 1967), p.142, cited by Colin Jones, The Great Nation (London: Penguin Books, 2003), p.276.
} 
The title of 'Prince de Soubise' is also mentioned in passing in a number of books. Often it is in reference to the Hôtel de Soubise, a famous building in Paris which was supposedly purchased by Charles de Rohan's great-grandfather, François de Rohan, on March 27, 1700. ${ }^{5}$ The interior of the hôtel was later decorated for the wedding of Hércule-Meriadec (Charles de Rohan's grandfather) to Marie de Courcillon, and was overseen by the famous French architect Germain Boffrand. ${ }^{6}$ The building today houses the Musée de l’Histoire de France and part of the Archives Nationales.

The following information about Charles de Rohan comes from two sources, Le gouvernement et l'administration sous Louis $X V$ : dictionnaire biographique by Michel Antoine (Paris: Éditions du Centre national de la recherche scientifique, 1978), and Histoire et Généalogie de la Maison de Rohan by Georges Martin (Lyon: G. Martin, 1998). The second of these books provides a detailed description and overview of the many branches of the Rohan family tree, with information on each individual person along with accompanying pictures. Unfortunately, Martin has not provided references for the information included. Perhaps this was because it was not deemed important for a genealogical study. In the present study, the information provided in his book has been used only to fill in the gaps on the life of Charles de Rohan where it is otherwise unclear, and thus it must be regarded as tentative, given that we have no other source to substantiate some of the information he provides.

Charles de Rohan (b Versailles 16 July 1715; d Paris 2 July 1787) was the son of Louis François Jules de Rohan, Duke of Rohan-Rohan, Prince de Soubise, and Captain Lieutenant of the Police and the Royal guard (b. 1697; d. May 6, 1724) and Anne Julie Adélaïde de Melun, princesse d'Epinoy (d. May 18, 1724). ${ }^{7}$

\footnotetext{
${ }^{5}$ Centre historique des Archives nationales, 'Les hôtels de Soubise et de Rohan au cœur du Marais. Un site d'exception chargé d'histoire...', available from www.archivesnationales.culture.gouv.fr/chan/chan/musee/action_culturelle/docs/Historique_Hot els.pdf accessed 7 April 2008. Renovations began on the Hôtel de Soubise in 1704 by the architect Pierre Alexis Delamair. Fiske Kimball, The Creation of the Rococo (Philadelphia Museum of Art, 1943), p.93.

${ }^{6}$ Germain Boffrand \& Caroline van Eck (ed.), Book of Architecture (England: Ashgate, 2002), p.xiii.

${ }^{7}$ Michel Antoine, Le gouvernement et l'administration sous Louis XV: dictionnaire biographique (Paris, Éditions du Centre national de la recherche scientifique, 1978), p.219.
} 
Charles was thus orphaned at the age of nine and from then on was raised at court where he became a close companion to Louis XV (b 1710; d 1774) who was almost the same age as the young prince. ${ }^{8}$

\section{Image 1, Charles de Rohan, Prince de Soubise. ${ }^{9}$}

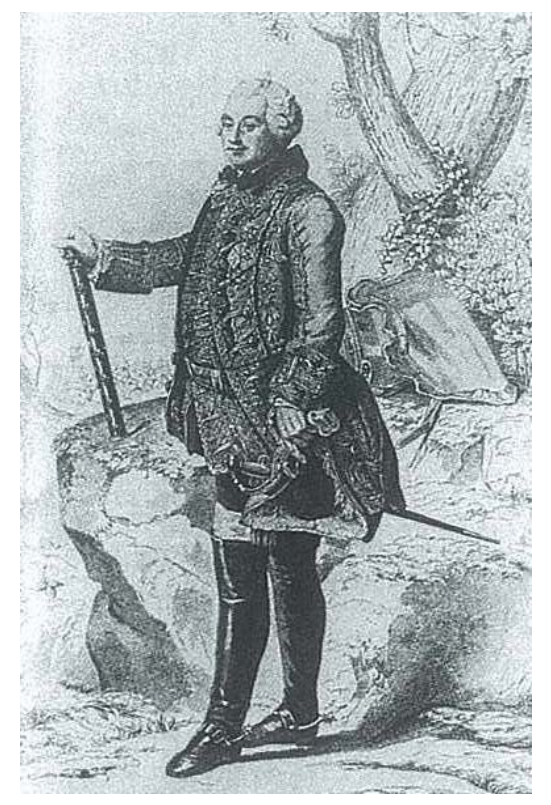

Charles de Rohan commenced his career in the military in May 1732, when he acquired the charge of the Police and the Royal guard; ${ }^{10}$ two years afterwards, on July 16th, 1734, he became captain of this company. ${ }^{11}$ According to Martin, in the following years Rohan accompanied Louis XV in his military campaigns until 1748. ${ }^{12}$ The friendship between the young king and Charles de Rohan was a loyal and steadfast one. In the siege of Fribourg in 1745, during which time Rohan was accompanying Louis XV in his military operation, Rohan supposedly broke his arm. Voltaire remarked that 'dès que le roi le sut, il alla le voir, il y retourna plusieurs fois. ${ }^{13}$ In the years following 1748 , Rohan went on to attain

\footnotetext{
${ }^{8}$ Georges Martin, Histoire et Genealogie de la Maison de Rohan (Lyon: G. Martin, 1998), p.117.

${ }^{9}$ Martin, 1998, p.219.

${ }^{10}$ Antoine, 1978, p.219.

${ }^{11}$ Ibid. See Antoine, 1978, p.219 for a succint summary of Rohan's military career.

12 Martin, 1998, p.117. Antoine states that on January 1, 1748, Rohan became the 'lieutenant général des armées du Roi’, 1978, p.219.

13 'As soon as the king knew, says Voltaire, he went to see him, and he went back to him several times.' Voltaire, Euvres complètes de Voltaire (Paris, Hachette, 1860), p.367 cited in Martin, 1998, p.117.
} 
high military rank and was named a Marshal of France in $1758 .{ }^{14}$ However, it would appear that this acquisition was less to do with his military ability and more to do with his favour with the king, Louis XV. ${ }^{15}$

Charles de Rohan's questionable military ability is most obvious in his contribution to the Seven Years War which was declared in June 1756 as a result of the hostility between Britain and France. The outbreak of the Seven Years War was tough on France which by mid 1757 was at war with Britain and Prussia. ${ }^{16}$ The French sustained many defeats, and the nation's confidence as a major power in Europe was knocked with the loss of territories and prestige. ${ }^{17}$ Whatever the truth may be about Charles de Rohan's military abilities, it was through the influence of Louis XV's mistress Madame Pompadour (1721-1764), that Charles de Rohan was given the command of an army of 24,000 troops. ${ }^{18}$ Although operations began positively, they were crushed by the Prussians at Rossbach in $1757 .{ }^{19}$ Charles de Rohan continued his military career for only a few more years, but his interest in the military remained for many more, which is clear in a letter he wrote to Voltaire on 15 November 1768:

\begin{abstract}
J'ai lu, monsieur, avec la plus grande attention et le plus grand plaisir les quatre volumes du siècle de Louis XIIII et de Louis XV, dont vous avez bien voulu me faire present...Vous avez traité avec une précaution favorable, pour moi, les trois articles dont vous me parlez dans votre lettre; j'en suis sensiblement touché. Vous avez appuyé sur les inconvénients des armées combinées et sur la difficulté de réunir et concilier les esprits des officiers du second ordre...Vous avez bien raison, je me suis trouvé dans le cas d'éprouver plus que personne de pareils embarras et les suites malheureuses ou désagréables qu'ils entraînent après eux...Pendant le séjour que les officiers de mon régiment ont fait dans votre voisinage, ils ne m’ont pas laissé ignorer les politesses dont vous les avez comblés et les amusements que vous leur avez procurés... ${ }^{20}$
\end{abstract}

\footnotetext{
${ }^{14}$ Antoine, 1978, p.219. By the end of the Middle Ages, the title of Marshal was of the highestranking military officers in France. Lucien Bély, Dictionnaire de l'Ancien Regime : royaume de France : XVIe-XVIIIe siecle (Paris: Presses universitaires de France, 1996), p.593.

${ }^{15}$ Martin, 1998, p.117.

${ }^{16}$ James C. Riley, The Seven Years War and the Old Regime in France (Princeton, N.J. : Princeton University Press, 1986), pp.74-5.

${ }^{17}$ Jones, 2002, p.170.

${ }^{18}$ Martin, 1998, p.118.

${ }^{19}$ Jones, 2002, pp.235-236.

20 'I have read, Monsieur, with the greatest attention and the greatest pleasure the four volumes about the century of Louis XIIII and Louis XV, which you were kind enough to present to me...Y You treated with favourable caution, for me, the three articles about which you are speaking to me in your letter; I am appreciative. You dwelt on the inconveniences of the combined armies and on the difficulty of uniting and reconciling the minds of the officers of the second rank... You are right; I found myself having to endure the difficulties and unhappiness that follow in their wake... During the stay which the officers of my regiment made in your neighbourhood, they did not let me ignore the courtesy which you bestowed on them and the entertainments which you found for them...' Charles de Rohan, prince de Soubise, to Voltaire c. 15 November
} 
Charles de Rohan had three wives, his first being Anne Marie Louise de La Tour d'Auvergne who he married on December 28, 1734, and they had a daughter, Charlotte de Rohan, who was born in Paris in $1737 .{ }^{21}$ Rohan's first marriage ended when Anne Marie Louise died in 1739 at the age of seventeen. ${ }^{22}$ His second marriage took place on November 6th, 1741 to Anne Thérèse de SavoieCarnignan. She also died at a young age in 1745, during the birth of Rohan's second daughter, Victoire de Rohan-Soubise. ${ }^{23}$ In the same year, Charles de Rohan wed his third wife, Anne Victoire Marie Christine, Princesse de HesseRhinfel-Rottenbourg. ${ }^{24}$ Rohan's luck did not improve with this marriage either, with his third wife being arrested at Tournai for running off with 90,000 livres worth of diamonds and jewellery to join her lover. ${ }^{25}$ The infidelity was mutual. One of Rohan's lovers was Mademoiselle Guimard (1743-1816), ${ }^{26}$ a well known French dancer in the corps de ballet at the Comédie Française, the Opéra, and King's Theatre in London. She became the première danseuse noble at the Opéra in 1763 and was one of the favourite dancers of the time. ${ }^{27}$ Another of Charles de Rohan's lovers was rumoured to be the young dancer of fifteen years, Mademoiselle Zacharie, who was a pupil of Mademoiselle Guimard. Perhaps his behaviour was inherited from his father who was notorious for his sexual exploits. $^{28}$

Charles de Rohan's adulterous exploits provide some confirmation that he was involved in the music and arts scene in eighteenth-century France, considering Mademoiselle Guimard was a well known artist. His other associates serve to reinforce this also. It has already been mentioned that he was a close friend of the king, Louis XV, and also his mistress, Madame Pompadour, a fabulous patron of the arts who actively encouraged many artists. She showed goodwill towards the

1768, Theodore Besterman (ed), Voltaire's Correspondence LXX Aug-Dec 1786 (Geneva : Institut et Musee Voltaire, 1953-1965), p.167-168.

${ }^{21}$ Martin, 1998, pp.123-124.

${ }^{22}$ Antoine, 1978, p.219.

${ }^{23}$ Martin, 1998, pp.123-124.

${ }^{24}$ Antoine, 1978, p.219.

${ }^{25}$ Martin,1998, p.121.

${ }^{26}$ Author not named, 'Guimard, Marie-Madeleine', Grove Music Online ed. L. Macy (Accessed 4 April 2008), http://www.grovemusic.com.

${ }^{27}$ Author not named, 'Guimard, Marie-Madeleine', Grove Music Online ed. L. Macy (Accessed 4 April 2008), http://www.grovemusic.com.

${ }^{28}$ See Francine du Plessix Gray, At Home with the Marquis de Sade (New York: Simon \& Schuster, 1998), pp.30 \& 67. 
philosophe movement in Parisian salons, ${ }^{29}$ supported individuals such as the future cardinal de Bernis who became a well-known writer, and helped to secure Voltaire’s place in the Académie française in 1746. Rohan's interest in literature is also confirmed by his correspondence with Voltaire: 'J'envoie une Tolérance à m. le prince de Soubise, le ministre d'état, qui la communiquera à m. le coadjuteur. J'en ai très peu d'exemplaires..., ${ }^{30}$ Obviously Rohan was on good terms with the famous philosophe if Voltaire sent him his work, and Voltaire seems to have respected him deeply, judging by the following letter:

Je vous tiens très heureux, Monsieur, de pouvoir passer vôtre hiver auprès d'un homme aussi généralement aimé et estimé qu $\mathrm{M}$ le Prince de $\mathrm{S}$...Il me semble que le public rend justice à la noblesse de son âme, à sa générosité, à sa bonté, à sa valeur, et à la douceur de ses moeurs. Il m'a fait l'honneur de m'écrire une Lettre à laquelle j'ai été extrêmement sensible... Je mourrai en le respectant. Je vous en dis autant, et du fond de mon coeur. ${ }^{31}$

Another contributing factor that confirms Charles de Rohan's involvement in cultural pursuits was the establishment of the popular subscription series in 1769 known as the Concert des Amateurs, in which weekly concerts were given at the Hôtel de Soubise, conducted by François-Joseph Gossec. ${ }^{32}$ The orchestra for the Concert des Amateurs included over sixty string instruments, a number larger than that of the opera, and also boasted some of the most skilful artists in Paris. ${ }^{33}$ It remains true, however, that all of these activities occurred in the years after Julie Pinel's 1737 publication, Nouveau recueil d'airs sérieux et à boire. We can assume that Charles de Rohan must have had an interest in the years preceding as

\footnotetext{
${ }^{29}$ C. Jones, Madame de Pompapdour. Images of a Mistress (London, 2002), p.120 cited in Jones, 2003, pp.130-131.

30 'I sent a 'Tolérance' to the Prince de Soubise, the minister of state, who will announce it to m. . le coadjuteur. I have very few copies of it ...' Voltaire to Gabriel Cramer, letter 10068, c. 4 Janvier 1763, Besterman, Vol. LI Jan-March 1763, 1953-1965, p.16.

${ }^{31}$ 'I am very happy, Monsieur, for you to be able to pass your winter near a man so in general loved and esteemed, Monsieur le Prince de S... It seems to me that the public acknowledges the nobility of his soul, his generosity, his goodness, his valour, and the gentility of his manners. It honoured me to be sent a letter in which I was extremely sensitive...I shall die respecting it. I say so much about it to you, and from the bottom of my heart.' Voltaire to François Gabriel Le Fournier, chevalier de Wargemont, letter 14472, c. 16 Janvier 1769, Besterman, Vol.LXXI JanApril 1769, 1953-1965, p.44.

${ }^{32}$ Elizabeth Cook, 'Paris>1723-89>Concert Life', Grove Music Online ed. L. Macy (Accessed 4 April 2008), http://www.grovemusic.com Gossec was a composer from the Netherlands who enjoyed a successful musical career in Paris for over fifty years. Barry S. Brook, David Campbell, Monicah. Cohn/Michael Fend, 'Gossec, François-Joseph', Grove Music Online ed. L. Macy (Accessed 7 April 2008), http://www.grovemusic.com.

33 One of the members of the orchestra was the French violinist Saint-Georges (1745-1799). Gabriel Banat, 'Saint-Georges [Saint-George], Joseph Bologne, Chevalier de', Grove Music Online ed. L. Macy (Accessed 4 April 2008), http://www.grovemusic.com.
} 
well, due to the number of artists he associated with, and because he had his own musical establishment, which included Julie Pinel.

One of Rohan's daughters was the dedicatee of a cantata in 1748 entitled L'oroscope (Paris, Bibliothèque nationale, Rès. R. 436), by an unfamiliar female composer, Hélène-Louise Demars (b. 1736). The piece was performed for Mademoiselle de Soubise on 21 November 1748, and the text was printed in the Mercure de France the following March. ${ }^{34}$ This is further testimony to the assumption that the Rohan family were well known in the musical life of eighteenth-century France, and that they patronised other artists, in addition to Julie Pinel.

\footnotetext{
${ }^{34}$ Julie-Anne Sadie, 'Hélène-Louise Demars', Grove Music Online ed. L. Macy (Accessed 4 April 2008), http://www.grovemusic.com Mlle Demars also published two cantatilles, Hercule et Omphale and Les Avantages du buveur. Sadie, 1986, p.209.
} 


\section{Chapter 3}

\section{Eighteenth-century Parisian Society: Salon culture, the French air, and the burgeoning Italian influence}

On the king's death in 1715, young Louis XV found himself facing a period in which opposition to the absolute power of the monarchy was increasing and where philosophers and writers mixed with nobility freely, discussing the political issues facing France. Philippe, Duc d’Orléans, took over as Regent in the same year because Louis XV was still a minor. The Duc d'Orléans pursued a life of debauchery and scandal, and as a result, the regency years were unproductive in fixing the problems left behind from Louis XIV's reign, when there was a quickly changing society to which the monarchy needed to adapt. Initially, Philippe set out to give the people the liberal reform they so desired, however, this soon reverted to the absolutism that defined Louis XIV's reign. France's finances were left in ruins, and corruption was rife. ${ }^{1}$ When the regency ended in 1723, Cardinal Fleury took on a dominant role in the ruling of France as ministre d'état, a member of a small group called the Conseil d'en haut. His time at the head of government was relatively successful, particularly when contrasted with the latter part of the reign of Louis XV. ${ }^{2}$

On Fleury's death in 1743, Louis made himself absolute monarch and discarded the idea of finding another minister to replace Fleury. Louis XV is described as a weak and shy monarch who had an addiction to hunting and drinking excessive amounts of alcohol. The initial infatuation that the public had for the young king following the affliction of deaths in the royal household early in the century had faded quickly by the time Louis XV reached adolescence. When he took on more responsibility as monarch in 1743 , he did not invest much concern in the matters of ruling France, or the responsibilities of his position. Not only did this not curb

\footnotetext{
${ }^{1}$ Robert Niklaus, The Eighteenth Century, 1715-1789 (London: Benn; New York: Barnes \& Noble, 1970), p.4.

${ }^{2}$ For a detailed overview of the eras of the Regent and of Fleury in the years 1715-1743, refer to Lough, 1960, pp.133-58.
} 
the growing discontent that the French felt towards the power and prestige of the monarchy, but the increasing displeasure against Louis XV was not helped by the weakening position that France found herself in during these years, particularly the Seven Years War in which France, Austria and Russia were pitted against Prussia and England. ${ }^{3}$ During this period, Prussia and Russia were gaining strength and Britain was undergoing its quest for colonial supremacy. ${ }^{4}$

Despite this, France maintained the upper hand when it came to cultural hegemony. Paris and Versailles were the scenes of a vibrant social life and there were many outstanding artists, poets, playwrights, composers and thinkers who enhanced France's reputation as the leading nation in the arts. ${ }^{5}$ Such a reputation had been refined during the reign of Louis XIV which was characterised by ceremony, etiquette and refined behaviour, otherwise known as goût. ${ }^{6}$ Goût embodied the philosophy and culture of honnêté, a doctrine which placed emphasis on the possession of certain moral virtues, based on the values of goût. ${ }^{7}$

Nowhere were these values more apparent than in seventeenth-century salons where they were cultivated. An understanding of seventeenth-century salon society is necessary for one to be able to follow the social and ideological changes that took place and which continued into the eighteenth century. Steven Kale writes that:

...salons emerged at a time when the justification of noble privilege in terms of a traditional military function was under attack, when circumstances promoted a more modern view of nobility based on a combination of birth, education, manners and sociability, and when an increasingly wealthy bourgeoisie was gaining entry into an expanding service nobility and aspired to 'live nobly. ${ }^{8}$

Salons were breeding-grounds for the necessary skills needed for life amongst the nobility, and Kale sums up salon sociability as:

sociability of leisure, a form of communication, an arena for social encounters, providing opportunities for conviviality, intellectual exchange, and unconventional social relationships...[all with] luxurious space, feminine governance, select company,

\footnotetext{
${ }^{3}$ Lough, 1960, p.165.

${ }^{4}$ Lough, 1960, pp.3-4.

${ }^{5}$ Lough, 1960, p.4.

${ }^{6}$ Michael Moriarty, Taste and Ideology in Seventeenth century France (Cambridge: Cambridge University Press, 1988), 88-89.

${ }^{7}$ Lough, 1957, p.228.

${ }^{8}$ Steven Kale, French salons : high society and political sociability from the Old Regime to the Revolution of 1848 (Baltimore : The Johns Hopkins University Press, 2004), p.9.
} 


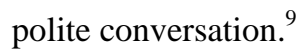

Seventeenth-century salons reinforced the aristocratic ideals of French society, but also challenged society by mixing members of the nobility and the bourgeoisie: ${ }^{10}$ 'Salons were indispensable socio-cultural adaptive mechanisms by which the integration of the newly ennobled into the structure of orders was completed. ${ }^{11}$

In particular, Kale's earlier quotation which mentions feminine governance is significant. With the proliferation of salons, women enjoyed an equal role to men and an important role in French social life generally. ${ }^{12}$ The distinguishing aspect of salons, compared to any other cultural institution of the time, was precisely their 'feminine governance, ${ }^{, 13}$ which aroused conflicting opinions. Intellectual activity among women had flourished since the emergence of the literary public sphere in the seventeenth century, ${ }^{14}$ encouraged by avant-garde thinkers such as Poulain de la Barre who suggested that sexual differences were purely physical and therefore had no bearing on one's intellect, concluding that women were just as able as men to hold public posts. ${ }^{15}$ However, other theorists such as Fleury and Fénelon argued that the education of women should be purely for the benefit of

\footnotetext{
${ }^{9}$ Kale, 2004, p.3.

${ }^{10}$ Kale, 2004, p.25. There were differentiations between the various types of noblesse in the seventeenth century. The nobles d'épée gained their recognition and nobility through militaristic achievement, while the noblesse de robe did so through their administrative service to the King. Lough, 1960, p.110. This division began to merge during the eighteenth century as a result of the continued influence of salons which were more and more accessible. Carolyn C. Lougee in Le Paradis des Femmes (Princeton, N.J.: Princeton University Press, 1976) asserts that there were some who attempted to retain professional differences between the subgroups of nobility even though they were socially combined and she puts forth the argument that salons preserved the aristocratic structure of French society rather than destroyed it (Lougee, 1976, p.212). 'Salons served to bring together nobles and intellectuals in an atmosphere of civility and fair play in order to educate one, refine the other, and create a common medium of cultural exchange based on a shared notion of honnêté that combined learning, good manners and conversational skill'. Lougee, 1976, pp.211-13 as cited in Kale, 2004, p.24.

${ }^{11}$ Lougee, 1976, p.212.

${ }^{12}$ Lough, 1957, p.225.

${ }^{13}$ Lougee, 1976, p.5.

14 Elizabeth C. Goldsmith, Going Public: Women and Publishing in Early Modern France (Ithica: Cornell University Press, 1995), p.5.

${ }^{15}$ Eva Jacobs (ed.), Woman and society in eighteenth-century France : essays in honour of John Stephenson Spink (London: The Athlone Press, 1979), p.3. Madame Geoffrin is one example of an eighteenth-century salônniere who hosted many important guests and artists including philosophes, artists, and nobles as well as men of letters, of lowlier origins. Salons such as Geoffrin's were particularly important to philosophes' success because they served as a forum to promote their careers and ideas. Other notable salônnieres from the eighteenth century include the Marquise de Lambert, Madame de Tencin and Madame Necker. Lough, 1960, pp.257 \& 271.
} 
family, posterity and society as a whole. Similarly, when it came to the salons, on one side, the leadership and governance of women was supported and celebrated as proof of their ability to hold major public roles, and on the other hand, there was opposition to women having any major public roles because of the enduring belief that women were inferior to men and thus unable to maintain such posts. ${ }^{16}$ In general, salons took on a more serious character and salônnieres were more educated. ${ }^{17}$ However, we must remember that while the salônnieres were remarkable, they only represented a small group of very intelligent, wealthy women whose very existence many considered to be a contradiction of the rules and structure of society. ${ }^{18}$

Nevertheless, the Parisian salon was adopting an increasingly hybrid character and it is analysed in detail by Lougee who describes eighteenth-century salons as melting pots which blurred the distinctions of birth, profession and sex. ${ }^{19}$ It was now easier to gain access to le monde (polite society) despite one's class or rank, as long as one had the correct manners, ${ }^{20}$ and this was most clearly seen in the increasing presence of wealthy bourgeois and men of letters in salons, as opposed to mere nobility.

The position of men of letters improved considerably during the course of the eighteenth century. In the seventeenth century, the occupation of writers was ridiculed and frowned upon. ${ }^{21}$ However, by the mid-eighteenth century, this attitude was beginning to change and writers were admitted into polite society as

\footnotetext{
${ }^{16}$ Lougee, 1979, p.6.

${ }^{17}$ Kale, 2004, p.18.

${ }^{18}$ Madelyn Gutwirth, Madame de Stael, Novelist (Urbana: University of Illinois Press, 1978), p.3. One of the early examples of opposition to the salon culture was the establishment of the Maison royale de Saint Louis at Saint-Cyr in 1686, founded by Madame de Maintenon. The school was designed to house about 250 daughters of impoverished army officers and noblemen, and to educate them in simple virtues that would produce a hard-working, domestic woman in a noble family. Maintenon aimed to educate young noble girls so that they would steer clear of polite society and the salon environment. Her avoidance of the salon practice is illustrated in the kind of music left behind at Saint-Cyr, which was composed for the 'usage de l'église et communauté des dames et demoiselles ... à Saint-Cyr'. Maintenon was in charge of the music, believing much of it to be too ornamental and florid. Lougee, 1976, p.173; James R. Anthony, 'Paris: Saint-Cyr', Grove Music Online ed. L. Macy (Accessed 2 February 2008), http:www.grovemusic.com.

${ }^{19}$ Lougee, 1976, p.170.

${ }^{20}$ Lough, 1960, p.264.

${ }^{21}$ Lough, 1957, p.198.
} 
equals to those from the aristocracy. ${ }^{22}$ In fact, French writers came to be revered for the power they wielded over public opinion. Lough describes this change in attitude towards men of letters with an example of one of the most notable figures from this period, Voltaire (b Paris, 1694; d Paris, 1778). ${ }^{23}$

The philosophes' views usually contrasted with the established authority (the monarchy) and this marked the difference between our period, and the seventeenth century, where writers had remained on good terms with the king. They had done so because patronage had provided an essential income in addition to that which they received from publishers. Louis XIV had expected that his patronage would, in turn, maintain his position of power and glory. Yet, the absolute monarch faced financial pressure near the end of his reign due to constant warring and extravagant spending, and this restricted his patronage. Fortunately, the combination of the growth in the size of the reading public, and the wider dissemination of literature during the eighteenth century, enabled some authors to earn a living independent of patronage. Yet, the publication of philosophical works such as those by Voltaire, coupled with popular uprisings against the monarchy, contributed to the growing spirit of unrest in France. The king's ministers attempted to curb this by banning the dissemination of certain philosophic pamphlets, including Voltaire's Lettres philosophiques which was publicly burned. ${ }^{24}$

Even though the monarchy continued its literary patronage in the eighteenth century, albeit on a smaller scale, the influence that Versailles previously had on literature and art had clearly shifted to Paris where polite society flourished. Conversation, wit, and the written word continued to remain important, with its

\footnotetext{
${ }^{22}$ Lough, 1960, pp.263-65.

${ }^{23}$ Voltaire is the most renowned of the philosophes, writers from this age who displayed their individual thoughts and beliefs concerning religion, politics and philosophy in their work, whilst also taking on the task of enlightening society in general. Initially, Voltaire's writings and wit often led him into trouble. He was first imprisoned in the Bastille prison for eleven months in 1717 after defaming the government in his poetry. Later in 1726, he was exiled to England after he offended the Chevalier de Rohan-Chabot, not returning until 1729. Then in 1734 he was forced to flee Paris once again, following the dissemination of his Lettres Philosophiques to which the French took offense, claiming that Voltaire implied that English institutions were superior to those in France. However, in complete contrast to such treatment, in 1778 he was celebrated and treated as a celebrity on his return to Paris. A.J. Ayer, 'Life and Character', Voltaire (New York: Random, 1986), pp.1-38.

${ }^{24}$ Ayer, 1986, pp.15-16.
} 
significance being reflected in the perpetuation of salons and the abundance of literature, art and music in this period.

This ideal is summed up by Catherine Gordon-Seifert with regard to the genre of the air, which makes up the majority of Pinel's Nouveau recueil:

An air's value was not necessarily based upon the quality of the song-texts nor even the musical settings, but rather that an air's worth was derived from its link to the most influential 'literary' model in France: 'la conversation à la française. ${ }^{25}$

Airs sérieux and airs à boire represent the final phase in the evolution of the air de cour in vocal chamber music.

Known for their simplicity, airs de cour were short, strophic songs first published in Le Roy and Ballard's 1571 publication, Livre d'airs de cour miz sur le luth, in which no distinction was made between the serious air and more fashionable forms such as the chanson à danser. ${ }^{26}$ By the late seventeenth century, the term air de cour was replaced by the separate terms air sérieux and air à boire. The eighteenth-century air à boire was typically a strophic, syllabic song with texts of a light, frivolous nature, whereas the air sérieux had texts about love, pastoral scenes or political satire. ${ }^{27}$ Catherine E. Gordon-Seifert describes the air sérieux in relation to the intimate nature of salon culture through its 'ability to express artfully that which could not be expressed directly', such as improper love, sexual arousal and seduction. ${ }^{28}$ Generally, the melodies of serious and drinking songs were simple and memorable. It was in the mid 1690s that the publication of serious songs and drinking songs became extremely popular, because it allowed composers to write music on a smaller scale than cantatas, operas and large-scale church works, and provided music for amateurs to enjoy and perform.

Ballard's monthly Recueils d'airs sérieux et à boire contained all the different

${ }^{25}$ Catherine Gordon-Seifert, 'La réplique galante: Sébastien de Brossard's airs as conversation', Sébastien de Brossard: musician, edited by Jean Duron (Paris: Centre de Musique Baroque de Versailles/ Editions Klincksieck, 1998), p.181.

${ }^{26}$ James R. Anthony, French Baroque Music (London: B.T. Batsford, 1978), p346. Airs de cour were polite courtly songs formerly known as the voix de ville and usually in simple binary form. Vollen, 1982, p.8.

27 John H. Baron, 'Air à boire’, Grove Music Online ed. L. Macy (Accessed 2 February 2008), http:www.grovemusic.com.

${ }^{28}$ Gordon-Seifert, La Donna Musicale, 2007, p.10. 
types of chamber air being written at the time, by a wide range of composers. ${ }^{29}$ The demand for Christophe Ballard's late seventeenth-century collection, Livres d'airs de différent autheurs, and especially for his monthly publication, Recueil d'airs sérieux et à boire which followed, demonstrates the significance of the air genre. ${ }^{30}$ The interest in Ballard's publications saw a number of people attempt to pirate his work, and up until the establishment of a new method of printing with engraved plates, the Ballard family maintained their monopoly over the distribution of airs. Prominent composers such as Bousset, ${ }^{31}$ Brossard, Campra, Couperin and Montéclair composed airs for Ballard's publication, and from the end of the seventeenth century women also began to contribute to this collection, most notably Jacquet de la Guerre. Other such women included Mesdemoiselles Bataille and Herville, while others chose to remain anonymous using asterisks in place of their name. ${ }^{32}$ One composer well represented in Ballard's collections was the French composer and singer Michel Lambert (1610-1696) who was the leading composer of the air sérieux in the second half of the seventeenth century. ${ }^{33}$ Lambert published hundreds of charming and simple airs and his influence persisted for some time after his death; his style being described as

\footnotetext{
${ }^{29}$ Greer Garden, 'Variations d'un reçu: Les airs de Desmarest publiés dans le Recueil d'airs sérieux et à boire de Ballard', Henry Desmarest (1661-1741) Exils d'un musicien dans l'Europe du Grand Siècle. Mardaga: 2005, p.356.

${ }^{30}$ Catherine E. Gordon-Seifert, Musical Voices of Early Modern Women (Aldershot Hants, England; Burlington, VT : Ashgate, 2005), p.135. Christophe Ballard (b. Paris, 12 April 1641; d. Paris, before 28 May 1715) followed in his father's role as sole music printer to the king from 1673 onward. Almost all music of the time was printed by the Ballard family including the works of Lully, Couperin, Campra, Brossard and many more well-known composers of the period. Jonathon Le Cocq: 'Ballard', Grove Music Online ed. L. Macy (Accessed 2 February 2008), http:www.grovemusic.com.

31 Jean-Baptiste de Bousset (1662-1725) is often described as the leading composer of airs sérieux et à boire. His large output is represented in fifty-eight song collections that he produced and Ballard issued more collections of airs by de Bousset than any other songwriter: Greer Garden, 'Bousset, Jean-Baptiste de’, Grove Music Online ed. L. Macy (Accessed 29 April 2008), http:www.grovemusic.com.

${ }^{32}$ Gordon-Seifert, 2005, p.14.

${ }^{33}$ Lambert's son-in-law was none other than Jean-Baptiste Lully, and the two composers worked closely with Lambert composing several pieces for Lully's ballets: Ballet des arts (1663); Ballet des amours déguisés (1664); and Ballet de la naissance de Vénus (1665). During the second half of the seventeenth century, Lully (1632-1687) was appointed to the privileged position of surintendant de la musique de la chambre du roi under Louis XIV and he played a significant role in the development of a distinctive French musical language. It has already been discussed that during Louis XIV's reign, Italian opera was not permitted due to the Académie Royale de Musique holding the monopoly; instead a number of French stage genres were cultivated including the pastoral, tragédie-en-musique, and opéra-ballet. So it was that Lully's style of composition and the role assigned to him as the leading French musician established his lasting influence for many years. Jérôme de la Gorce, 'Lully', Grove Music Online ed. L. Macy (Accessed 29 April 2008), http:www.grovemusic.com.
} 
exemplary. For the most part, the Ballards' song collections between 1694 and 1730 continued to maintain the pure, 'classic' French style of Lambert.

The musical public were no doubt won over by the notions of those like JeanLaurent Lecerf de La Vieville who was pro-French:

Think of an overdressed, middle-aged coquette, made up to the nines with powder, rouge and beauty spots, applied with all the care and skill she can muster, hiding the wrinkles on her faces and the blemishes in her figure with apparel chose with the same care; smiling and grimacing in the most carefully chosen and rehearsed manner; always trying to shine and be animated whether it is appropriate or not, having acquired above all the art of amusing small talk, and upsetting people, all without any heart, soul, or sincerity, seeking only change. There's Italian music for you.

Now imagine a young person of noble demeanour, modest, always dressed with an eye to appropriate fashion, but preferring to seem under rather than overdressed, appearing in all her finery only upon occasion. Lively, in excellent health, with an impeccable figure, and a natural complexion - distancing herself from all that is false or borrowed wearing a beauty spot or two from time to time to cover the occasional blemish, smiling and gracious, but not acting the coquette; a gentle soul, without airs and graces, natural, but capable of seriousness, speaking well without making anything of it, able even to refrain from speaking. Sincere, sensitive, always even-tempered and always attractive. There you have French music. ${ }^{34}$

Other aspects contributed to the persistence of la musique ancienne in France. As has already been stated, at the close of the seventeenth century, the royal family stepped back from their role in musical patronage meaning that new stage works were not commissioned as often as they previously had been and old works were thus resorted to. ${ }^{35}$ As Weber claims, many French people had grown accustomed to music from the past and simply preferred it over new forms of music. ${ }^{36}$

However, even before the regency, the stranglehold that Louis XIV had held over French music began to weaken. Attention turned away from Versailles and towards Paris where society and culture was becoming increasingly cosmopolitan, and where the Italian influence, already felt throughout the rest of Europe, was filtering in. ${ }^{37}$ Italianism gradually seized Paris during the early eighteenth century for a number of reasons. Late seventeenth-century France had seen political, economic, religious and social disharmony and discord with Louis XIV having been at war. The Wars of the League of Augsburg (1688-97) and of

\footnotetext{
${ }^{34}$ Jean-Laurent Lecerf de la Viéville, seigneur de Fréneuse, Comparison de la musique italienne et de la musique française (Genève: Minkoff Reprint, 1972).

${ }^{35}$ The Académie Royale de Musique had control over the initiation of new works and the concentration of music in Paris prevented provincial theatres from creating new operas. W. Weber, 'La musique ancienne in the waning of the ancien régime', Journal of Modern History, Vol. 56, no. 1, 1984, pp.61-63.

${ }^{36}$ Weber, 1984 p.65.

37 Jones, 2003, p.19.
} 
Spanish Succession (1701-13) greatly damaged France's economic state of affairs, and while things began to settle down in the eighteenth century, France was still in debt. These events signalled the decline and end of Louis XIV's reputation as the 'Sun King' and 'Louis the Great', and similarly, this time began to see the decline of la musique ancienne in France, as well as the growth of the Italian style in eighteenth-century French music. Italian music and performers enjoyed increasing popularity in Paris with Italian singers performing at the Concert Spirituel and at private concerts. ${ }^{38}$

Examples of Italian influence are outlined by James R. Anthony in his article 'Air and Aria added to French Opera from the death of Lully to 1720 '. 39 Anthony's research shows that Italian arias were starting to be included in French stage genres before the close of the seventeenth century. For example, André Campra's L'Europe galante (1697) was the first opéra-ballet to include an Italian aria in da capo form; 'Ad un curore' displays the Italianate characteristics of ritornelli, melismas, repetition of text and compound meter. ${ }^{40}$ Also, the works of Italian composers including Rossi, Scarlatti and Carissimi were promulgated in Christophe Ballard's Recueils des meilleurs airs italiens between 1699 and 1708. ${ }^{41}$ These Italian collections brought Frenchmen into close contact with the da capo aria; a few Frenchmen writing in Italian style are also represented.

Another fashionable genre which flourished in the final years of Louis XIV's reign, in response to the burgeoning enthusiasm for Italian music, was the cantate française. The cantate française differed from the courtly, classical style that had dominated French music during Lully’s career. ${ }^{42}$ The cantata originated

\footnotetext{
${ }^{38}$ Mary Cyr, 'Eighteenth-Century French and Italian singing: Rameau’s writing for the voice', Music and Letters, Vol. 61, no. 3/4, Jul-Oct 1980, p.318.

39 James R. Anthony, 'Air and Aria added to French Opera', Revue de Musicologie, Vol. 77, no. 2, 1991, pp.201-219.

40 Anthony, 1991, p.209. One example of the Italian influence in French airs was the inclusion of basse continue parts. These were sporadically included in some early seventeenth-century airs, however, it was not until Ballard's 1652 publication of Du Mont's Cantica sacra that basse continue overtook lute tablature. Titon du Tillet, Parnasse francois (Paris: Gallimard, 1991), p.54.

${ }^{41}$ Anthony, 1991, p.211-213. A list of French composers whose Italian arias were published in Ballard's series Recueil des meilleurs airs italiens between 1699-1708 is given by Catherine Massip, 'Airs français et italiens dans l'édition française 1643-1710', Revue de musicology, Vol. 77, no. 2, 1991, p.183.

${ }^{42}$ David Tunley, The Eighteenth Century French Cantata (London: Dennis Dobson, 1974), p.15-
} 
as a literary form before becoming a musical genre. Jean-Jacques Rousseau wrote of its creator, Jean-Baptiste Rousseau: 'The illustrious Rousseau is the creator of this genre among us. He made the first French cantatas; and in almost all, one sees the poetic fire with which this rare genius was animated. ${ }^{43}$ The musical cantata comprised a series of alternating airs and recitatives, were usually based on the topic of love, and concluded with a final moral or maxim of some kind. J.-J. Rousseau defines it in his Dictionnaire de musique as 'a type of short lyric poem, which is sung with accompaniment and which, although written for the chamber, should receive from the musician the warmth and the gracefulness of imitative and theatrical music. ${ }^{44}$ In turn, another genre developed out of the cantata, an example of which can be found in Pinel's collection. The structure of a cantatille is similar to that of a cantata in which the recitatives establish a time and setting, and develop a plot, and the airs framing them represent a reaction to the recitative. Typically a cantatille consisted of two recitative-air pairs - it was a smaller form in imitation of the cantata, however, some believed that the smaller structure of the cantatille reflected the lesser quality of the genre, as is made clear in the following extract from Rousseau's Encyclopédie:

[the cantatille is] only a very short cantata, whose subject is linked by a few verses of recitative and two or three "airs en rondeau" usually with instrumental accompaniment. The cantatille style is worth even less than that of the cantata, for which it has been substituted among us. But, as one can develop in it neither passions nor "tableaux," and it is capable only of prettiness, it is a resource for little versifiers and for musicians without genius. ${ }^{45}$

Described as rococo, these works were often adorned with ornamental flourishes and bravura, displaying the influence of Italianate characteristics in French music.

At the same time, there was a shift in the perception about who could best pass

16. 'The French cantata was characteristically a six-movement form of alternating recitatives and airs for solo voice, accompanied either by continuo alone or with continuo and obbligato instrument.'; Malcolm Boyd: 'Cantata' Grove Music Online ed. L. Macy (Accessed 5 September 2007), http://www.grovemusic.com.

${ }^{43}$ Jean-Jacques Rousseau, “Cantata”, Encyclopédie, ed. Denis Diderot II, (Paris, 1751-1772), pp. 261-62 cited in Vollen, 1982, p.57.

${ }^{44}$ George J. Buelow, A History of Baroque Music (USA: Indiana University Press, 2004), pp.185-186.

${ }_{45}$ Jean-Jacques Rousseau, “Cantata”, Encyclopédie, ed. Denis Diderot II, (Paris, 1751-1772), p.621, translated in Vollen, 1982, p.16. 
aesthetic judgement in France. Until then, it had been widely accepted that polite society were those who assumed the right to judge cultural matters in France, in which music was included: ${ }^{46}$

In matters of music one can distinguish two kinds of people: those who may be called the low people, the servants, shop assistants, artisans, porters, etc., who listen to songs of the Pont Neuf and do not go at all to the Opéra; the other kind, the honnêtes persons, a distinguished multitude who frequent the spectacles... ${ }^{47}$

Polite society's authority on matters of taste was to be challenged in the later eighteenth century in what is known as the Querelle des Bouffons (1752-1754). Opera lay at the heart of the Querelle, with Grimm declaring that 'it [was] up to the philosophes and [that this was] the time to fix this taste and to restore it corrected to the nation. ${ }^{48}$ The quarrel, in which French music (by then represented by Rameau) was now thought too complex and Italian music (represented by the simple style of Pergolesi's La Serva padrona) was considered superior, became a point of contention between salonnières and philosophes who had thus far consulted each other when it came to taste and supported each other within the setting of salons. ${ }^{49}$ Parisian women had previously been viewed as valuable judges on taste due to their adherence to the values of goût and honnete. However, the philosophes rejected their role as arbiters of taste and instead proclaimed that French women actually displayed a lack of taste in their allegiance to all things French.

\footnotetext{
${ }^{46}$ J. T. Pekacz, 'The Salonniere and the Philosophes in Old Regime France: The Authority of Aesthetic Judgement', Journal of the History of Ideas, Vol. 60, no. 2, April 1999, p.277.

${ }^{47}$ Nicolas Racot de Grandval, Essai sur le bon goust en musique (Paris, 1732), 52 quoted in Pekacz, p.285.

${ }^{48}$ Frederick Melchior Grimm, “Lettre sur Omphale,” Correspondance littéraire, philosophique et critique, ed. Maurice Tourneux (16 vols.; Paris, 1877-82), XVI, 301-2 quoted in Pekacz, p.287

${ }^{49}$ Pekacz, 1999, p.278 \& 289.
} 


\section{Chapter 4}

\section{Women musiciennes in eighteenth-century France}

In general, public and professional life was closed to women, and for a woman to undertake paid activity as a professional musician, and especially to compose and publish, ran counter to the prevailing construction of femininity which placed women firmly in the familial and domestic domain. The nature and proper role of woman was the subject of impassioned and protracted debate which lasted throughout the seventeenth and eighteenth centuries, and touched on every sphere of life - family, education, culture and politics. ${ }^{1}$

Women who became professional composers were the exception in the eighteenth century because they challenged the traditional and accepted roles attributed to them. As a rule, even though women had been encouraged to pursue music, it was assumed that they would do so only as a form of private entertainment. Consequently, women who pursued music as a profession were 'surrounded by an aura of moral ambiguity.'2 Thus, it was not uncommon for female composers to remain anonymous. In fact, one of the earliest female composers that we know of, Hildegard of Bingen (1098-1179), remained hidden for many years and there are numerous works from our period also attributed to anonymous women. ${ }^{3}$ The questions surrounding women and their role in professional life also persisted beyond the eighteenth century, as is shown from Felix Mendelssohn's comments on the limits of his sister's ability to publish music:

I consider publishing something serious [...] and believe that one should do it only if one wants to appear as an author one's entire life and stick to it [...] Fanny, as I know her, possesses neither the inclination nor calling for authorship. She is too much a woman for that, as is proper, and looks after her house and thinks neither about the public nor the musical world [...] Publishing would only disturb her in these duties, and I cannot reconcile myself to it. ${ }^{4}$

Women have long been aware of the dichotomy facing them:

\footnotetext{
${ }^{1}$ R. Leppert, Music and image (Cambridge, 1998) as cited in Margaret Yelloly, 'The ingenious Miss Turner', Early Music Vol.33, no.1 (2005), p.76.

2 Jolanta T. Pekacz, The Formative Effect of Honnêtté on Parisian Salons (New York: Peter Lang, 1999), p.119.

${ }^{3}$ Marcia J. Citron, Gender and the Musical Canon (Cambridge: Cambridge University Press, 1993), p.98.

${ }^{4}$ Letter to Lea Mendelssohn, 24 June 1837, in the New York Public Library, Briefe aus den Jahren 1830-1847, ed. Paul Mendelssohn Bartholdy and Carl Mendelssohn, $3^{\text {rd }}$ ed. (Leipzig, 1875), vol. II, pp.88-9, cited and translated by Citron, 1993, p.110.
} 
I cannot help feeling a keen schism at times between the composer, who is a more generalized and abstract part of myself, and the woman, who is daily aware of, and made aware of, what it means to be a composer and a woman. I do believe that, for all the ambiguity and complexity which impacts this double identity, it is possible and necessary to separate the two. ${ }^{5}$

The previous chapter highlighted the role of women as salônnieres in eighteenthcentury France, and the criticism faced by some. The 'woman' discussion and debate has been ongoing with various twentieth-century scholars today contributing to the research on what has since been termed 'feminist musicology'. Musicology has opened its doors to more and more ideologies and in doing so the canon has transformed itself, now allowing female composers such as Fanny Mendelssohn to be included. Suzanne Cusick’s essay 'Gender, Musicology, and Feminism' argues that 'musicology can benefit from the new vision that can be revealed by the simple act of changing point of view [and that] feminist musicologies lead us to new ways of thinking about the relationship of the canonic tradition to heretofore obscure musical practices, and to new ways of thinking... ${ }^{6}$ Feminist musicology challenges areas of traditional philosophy on the grounds that they fail to take women's interests, identities and issues seriously; and that they fail to recognise women's ways of being, thinking and doing as valuable to men. Part of this is because western culture has associated rationality with masculinity and emotionality with femininity, an idea illustrated in Mendelssohn’s quote regarding his sister.

Marcia J. Citron's book Gender and the Musical Canon offers an insightful approach to feminist musicology. Citron differentiates between 'woman' and 'women' to dispel the dangers of generalising and essentialising women as a large group which she argues can 'diminish the importance of social context and individual difference. ${ }^{7}$ Cusick also clarifies the term 'canon' explaining that women have been largely excluded from musical canons. She claims that only professional composers are viewed as 'worthy composers' and are thus part of the canon.

\footnotetext{
${ }^{5}$ Diane Thome, in the responses by women composers in Perspectives of New Music, as gathered by Elaine Barkin: volume 20-21 (1981-2), pp.288-329, cited by Citron, 1993, p.84.

${ }^{6}$ Suzanne G. Cusick, 'Gender, Musicology, and Feminism', Nicholas Cook and Mark Everist (eds.), Rethinking Music (Oxford: Oxford University Press, 1999), p.497.

${ }^{7}$ Citron, 1993, p.7.
} 
However, women composers have been devalued because they have not traditionally been considered professionals. ${ }^{8}$ The ideology of the 'canon' has a lot of authority over most aspects of music. The canon is an accepted principle, rule or criterion and an authoritative list of works. Ellen Koskoff believes that 'creating and perpetuating canons and their values is a way of defining ourselves musically and socially. ${ }^{9}$ Females have been repressed due to social construction (socialised largely in male terms) and psychological predispositions, and one of the effects of this in the eighteenth century, was the tendency for female composers to remain anonymous.

Despite these issues, and despite their class, many young women were provided with the opportunity to have musical tuition. Women from the aristocracy or from princely families studied music with Europe's best professional musicians, but even had they wished to, they were not able to become professional musicians themselves, due to their social status. Perhaps in compensation, aristocratic and upper-class women in Paris hosted artistic and intellectual gatherings in their homes known as salons, which were elaborated upon in the previous chapter.

Those women who were able to become professional performers and composers came from a subset of the middle class and crucial to their success was the encouragement and support from family and/or other musicians. Without such support, women were not able to pursue this path professionally. The absence in the profession of women lacking family connections provides evidence that a middleclass woman had no means of entering the profession with simply talent alone. ${ }^{10}$ Women were hired by institutions like the Académie Royale de Musique, for roles as dancers and singers. Female sopranos were admitted from the time of Lully, and fully accepted as solo artists in concert life and in opera in Paris. ${ }^{11}$ Women as instrumentalists made their way into the ranks of court musicians more slowly, and

\footnotetext{
${ }^{8}$ Citron, 1993, p.10.

9 Ellen Koskoff, 'What Do We Want to Teach When We Teach Music?', Nicholas Cook and Mark Everist (eds) Rethinking Music (Oxford: Oxford University Press, 1999), p.548.

${ }^{10}$ Sadie, 1986, p.200.

${ }^{11}$ Sadie, 1986, p.192.
} 
those who succeeded were usually daughters of court musicians. ${ }^{12}$

Examples of this are the Couperin sisters and daughters of François Couperin who both inherited their father's performing skills on the harpsichord. ${ }^{13}$ The better known of the two was Marguerite-Antoinette Couperin (1705-1778), whose playing was described by Titon du Tillet as 'de la manière sçavante et admirable... ${ }^{14}$ She was active in court, and named in L'Etat de la France in 1749 with the post, Clavecin et Basse d'accompagnement/Chambre, Maître de Clavecin/Mesdames de la Cour. ${ }^{15}$

Mademoiselle de Menetou ${ }^{16}$ provides another example of a French female musician whose parents and grandparents were patrons of the foremost musicians of the period. Menetou was a talented harpsichordist, singer and composer from a young age, having a collection of fifteen airs of her composition published in 1691 when she was eleven years old. This was at a time when Christophe Ballard was not publishing many collections by individual composers, let alone those by females, and young females at that. ${ }^{17}$ The only other collection of airs published by a female composer in the Baroque period was by none other than Julie Pinel in 1737: Nouveau recueil d'airs sérieux et à boire, the collection at the centre of this study. The long gap between these publications makes clear how unique their situations were in having their work published in an individual collection. Other female composers only had individual airs published within general collections, such as

\footnotetext{
${ }^{12}$ In the past, women had only been encouraged to sing or play a keyboard instrument due to the decorum surrounding which instrument could be played by which sex. For example, it was believed that brass and percussion were not visually flattering, as opposed to the harp or harpsichord which have been associated with women since the Renaissance. Sadie, 1986, p.195.

${ }^{13}$ Marie-Madeleine (1690-1742) entered a convent and may have been the organist at the royal abbey of Maubuisson: David Fuller, 'Couperin’, Grove Music Online ed. L. Macy (Accessed 2 February 2008), http:www.grovemusic.com.

${ }^{14}$ Evrard Titon du Tillet, Vies des Musiciens et autres Joueurs d'Instruments du règne de Louis le Grand (Paris: Gallimard, 1991), p.38.

${ }^{15}$ Cohen, 1992, p.785.

${ }^{16}$ Her name was Françoise-Charlotte de La Ferté, born into a prosperous family who were close to the king. Greer Garden, 'Songs by a child prodigy: the Airs srieux à deux (1691) by Mademoiselle de Menetou' (Conference paper from Tenth International Biennial Conference on Baroque Music, University of La Rioja, 17-21 July 2002), pp.3-4.

${ }^{17}$ Garden, 2002, p.7.
} 
Mademoiselle Sicard ${ }^{18}$, the daughter of Jean Sicard, ${ }^{19}$ whose airs were included in her father's books between 1678 and 1682. ${ }^{20}$

The French were enamoured of young girls who displayed exceptional talent ${ }^{21}$ as is clear from the following statement from Titon du Tillet about another young girl, the best-known French female musician from this period, Elisabeth-Claude Jacquet de La Guerre (1665-1729):

Mademoiselle Jacquet dès sa plus tendre jeunesse fit connoître des talents et des dispositions extraordinaires pour la Musique et pour l'art de toucher le clavecin. À peine avoit-elle quinze ans, qu'elle parut à la Cour. Le Roi eut beaucoup de plaisir à l'entendre jouer du Clavecin...22

Jacquet de La Guerre was a child prodigy, renowned for her performing abilities, improvisatory skill and impressive compositional output. ${ }^{23}$

Madame de la Guerre avoit un très beau genie pour la composition, et a excellé dans la Musique vocale, de meme que dans l'instrumentale, comme elle l'a fait connoître par plusieurs ouvrages dans tous les genres de Musique qu'on a de sa composition...On peut dire que jamais personne de son sexe n'a eu d'aussi grands talents qu'elle pour la composition de la musique, et pour la manière admirable don’t elle l'exécutoit sur le Clavecin et sur l'Orgue. ${ }^{24}$

Jacquet de La Guerre descended from a long history of musicians and instrumentmakers on her father's side; her father, Claude Jacquet was the organist and maître de clavecin of the church of Saint-Louis. From a young age, Jacquet de la Guerre

${ }^{18}$ First name is unknown. James R. Anthony, 'Sicard, Jean', Grove Music Online ed. L. Macy (Accessed 28 January 2008), http:www.grovemusic.com.

${ }^{19}$ Jean Sicard was a prominent French singer and composer who produced 17 books of airs during his career. James R. Anthony, 'Sicard, Jean', Grove Music Online ed. L. Macy (Accessed 3 September 2007), http://www.grovemusic.com.

${ }^{20}$ Books 13-16. Cf. Ondine Godtschalk, Love's Desires and the Pleasures of Bacchus: The Airs of Jean Sicard (fl. 1660-1683), MMus diss. (Victoria University of Wellington, 1999), 1: 181 cited in Garden, 2002, p.1.

${ }^{21}$ Garden, 2002, pp. 2 \& 7.

22 'Mademoiselle Jacquet, from her most tender youth enjoyed an extraordinary talent and disposition to music and harpsichord playing. At barely fifteen years old, she appeared at the Court. The King was very pleased by her Harpsichord playing...' Titon du Tillet, Vies des Musiciens et autres Joueurs d'Instruments du règne de Louis le Grand, 1991), p.30.

${ }^{23}$ For an overview of Jacquet de la Guerre's life and a full list of her works, see Cessac, 1995.

24 'Madame de la Guerre had a very great genius for composition, and excelled in vocal music the same as in instrumental; as she has made known by several works in all kinds of music that one has of her compositions... One can say that never had a person of her sex had such talents as she for the composition of music, and for the admirable way she performed it at the harpsichord and on the organ.' Evrard Titon du Tillet, Le Parnasse Française, 1732, quoted and trans. Sylvia Glickman and Martha Furmen Schleifer, From convent to concert hall: a guide to Women Composers (London: Greenwood Press, 2003), p.74. 
was educated at court as a singer, organist and harpsichordist under the guide of arts patron Madame de Montespan. ${ }^{25}$

Jacquet de La Guerre's output consists of a wide variety of compositions, including vocal, instrumental and dramatic works. She was the first French woman to compose and publish collections of cantatas which display her ability to compose diversely. Not only were her first two books of cantatas, published in 1708 and 1711 respectively, particularly unique because the texts are based on stories from the Old Testament, but they also display an amalgamation of French and Italian characteristics. ${ }^{26}$ Furthermore, her sonatas were among the first of those composed in France. ${ }^{27}$ Her extant vocal music includes nine airs, some of which were printed in Réné Trépagne de Menerville's Les amusemens de Moneigneur le duc de Bretagne (1712), and others were printed between 1710 and 1724 in Christophe Ballard and Jean-Baptiste-Christophe Ballard's popular series Recueils d'airs sérieux et à boire. ${ }^{28}$

Jacquet de La Guerre also represents the small group of women who ventured into composing for large genres, with her tragédie en musique, 'Céphale et Procris' being both published and performed by the Académie Royale de Musique in $1694 .{ }^{29}$ Often women did not have the opportunity or means to achieve success in such genres. Consequently, most music composed by women in the eighteenth century tended to be on a small scale, such as the simple airs found in Pinel's 1737 collection. Also, musical composition by women was often only possible with the assistance of a patron and a lot of the music composed by women was done so at a young age before marriage or family responsibilities.

\footnotetext{
${ }^{25}$ Mary Cyr, Elisabeth-Claude Jacquet de La Guerre: The Collected Works Vol.3 (New York: The Broude Trust, 2005), p.xiii.

${ }^{26}$ Mary Cyr, 'Representing Jacquet de La Guerre on disc: scoring and basse continue practices, and a new painting of the composer', Early Music, Vol. 32, no. 4, Nov 2004, pp.549-550.

${ }^{27}$ Susan Erickson, James R. Briscoe (ed.), 'Elisabeth-Claude Jacquet de la Guerre', New Historical Anthology of Music by Women (USA: Indiana University Press, 2004), pp.80-81.

${ }^{28}$ Mary Cyr, 2005, p.xiii.

${ }^{29}$ Mary Cyr, 2005, p.xiii.
} 
Several women found success in other professions in eighteenth-century France, such as Elizabeth Catherine Ballard who was an active publisher. ${ }^{30}$ In a similar way to female musicians, this usually occurred through family connections. Women led the field in the engraving profession, Madame Leclair and Mademoiselle Vendôme being two examples. ${ }^{31}$ Notable female poets from this period include Mademoiselle Chéron, Madame La Hay and Madame Deshoulières. Ursula M. Rempel's article 'Women and Music' includes a chart which shows the distribution of women's roles in music between 1715 and 1789 which is included below: ${ }^{32}$

Figure 1 Distribution of women's roles in music, 1715-1789.

\begin{tabular}{|l|c|}
\hline Singers & 75 \\
\hline Dancers & 117 \\
\hline Keyboard Players & 24 \\
\hline Court musicians & 7 \\
\hline Harpists & 20 \\
\hline Violinists & 2 \\
\hline Teachers & 6 \\
\hline Composers & 57 \\
\hline Publishers & 34 \\
\hline
\end{tabular}

It is apparent from looking at this chart that most women succeeded as performers, however, women appear in more than one category in many cases. Julie Pinel is a perfect case in point, providing an example of a female musicienne who fits more than one category as a professional woman in eighteenth-century France. Her 1737

\footnotetext{
${ }^{30}$ She is discussed in Chapter 1 with regard to Pinel's collection which was published by La Veuve Boivin, the name Ballard used.

${ }^{31}$ Donald W. Krummel, 'Printing and Publishing of Music', Grove Music Online ed. L. Macy (Accessed 21 April 2008), http://www.grovemusic.com.

${ }^{32}$ Ursula M. Rempel, 'Women and Music: Ornament of the Profession?', Samia I. Spencer (ed.), French Women and the Age of Enlightenment (Bloomington: Indiana University Press, 1984), p.174, put together from a variety of sources. Aaron I. Cohen, International Encyclopedia of Women Composers (New York: Bowker, 1981); Don L. Hixon and Don Hennssee, Women in Music: A Bibliography (Metuchen, NJ: Scarecrow, 1975); Emile Campardon, L'Académie royale de musique au XVIIIe siècle (1884; New York: Da Capo, 1971); Constant Pierre, Histoire du concert spiritual (Paris: Société française de musicology, 1975); Jeannie G. Pool, Women in Music History: A Research Guide (New York: Pool, 1977).
} 
collection of music proves that she was a published composer and poet and music cataloguer Boisgelou attested to her having been a teacher of the harpsichord. ${ }^{33}$ It is very likely that Pinel would have performed on occasion, given her apparent harpsichord abilities and because her patron, Charles de Rohan, was not only a favourite of the king, Louis $\mathrm{XV}$, but he associated with various eighteenth-century artists, regularly attended the opera and most likely participated in Parisian salon culture. $^{34}$

${ }^{33}$ See Chapter 1 of this study.

${ }^{34}$ See Chapters 2 and 3 for more information on Charles de Rohan, Prince de Soubise. 


\title{
Chapter 5
}

\section{The Poetry in Pinel's Nouveau recueil}

\begin{abstract}
[Poetry was] closely interconnected [with] the world of letters [...and] with the historical and artistic development of the period. It is characteristically ancien régime, and is open to the same phases of rococo and neo-classicism that we have found in the other arts [...] But the picture is more blurred, and the interweaving more complex. There is a lavish use of mythology, increasing representation of idylls in Arcady; which coupled with a growing discontent and need of innovation, fomented by new influences from overseas, brought fresh impetus to a flagging inspiration... ${ }^{1}$
\end{abstract}

Eminent poets from the eighteenth century include Voltaire and André Chénier. However, the writers of verse for airs were, in the main, literary amateurs with no claim to greatness as poets. In addition to this high-style poetry, there existed a whole repertoire of far less ambitious verse, written for the entertainment of society, notably seen in the salons.

Eighteenth-century poetry for the air retained close ties to seventeenth-century poetry which emerged as verse for society consumption, being lighter and less serious and which is described by Louis Auld thus:

We find a profusion of light, courtly, precious verses of all descriptions. Everywhere, the play on words echoes the witty turn of thought; hyperbolic praises of the momentary <object> of adoration elicit a complementary outpouring of poems of misogyny and brutal, hateful sentiment; myriad drinking songs [...] revealing a curious development in the sensibility of the writers [...] the change is characterised by fascination with distortion, travesty, the misshapen, the parodistic reflection of beauty, the negative side of elevated moral principles. ${ }^{2}$

On the surface, those at court and in the salons displayed strict religiosity and honnêté, however, underlying it all was a penchant for an almost libertine behaviour. Thus, in literature from this period, a moral duplicity was evident.

One change that occurred in the transition from the seventeenth to the eighteenthcentury is that airs displayed a transformation in gender representation which coincided with the diminishing influence of men over women and the

\footnotetext{
${ }^{1}$ Niklaus, 1970, p.57.

${ }^{2}$ Louis E. Auld, The lyric art of Pierre Perrin, founder of French Opera (Henryville, Pa., USA: Institute of Mediaeval Music, 1986), vol.1, p.19.
} 
masculinised public sphere. ${ }^{3}$ Catherine E. Gordon-Seifert describes the airs of the mid to late-seventeenth century as symbols for gender representation. For example, in many airs, men are attempting to manipulate their beloved, and women are typically represented by either silence or boldness in character. ${ }^{4} \mathrm{By}$ the late seventeenth century, airs were lighter in disposition and were more concerned with the enjoyment of nature. Importantly, airs became more genderneutral and many had a female poetic voice, which is prevalent throughout Pinel's collection. This provides a sign that she was aware of the developments occurring in music and literature at the time and participated in them.

\section{THE POETS}

Probably the most unusual aspect of Mademoiselle Pinel's collection is that she claimed the authorship of many of the poems which she set to music: 'Toutes les paroles de ce Recueil, excepté celles qui sont aux noms de M.rs sont du meme auteur que la musique'. ${ }^{5}$ In the collection, twelve airs contain texts by an anonymous poet or poets, indicated by handwritten inscriptions in the edition. It is unclear whether Pinel herself wrote these indications on the music, or if it was an owner of the music. We do know, however, that they are written in an eighteenth-century hand. The other uncertainty is whether Pinel used texts by more than one author. Some of the inscriptions differ slightly which suggests that they might come from more than one author or source. Nine airs have a variation of the inscription, 'Les paroles sont de Mr...', however, the air 'Que Tircis est charmant' has the indication 'Paroles anciennes', and 'Buvons Lucas' is labelled 'Paroles de Mr C...'

René Drouard de Bousset (1703-1760) also set one of the same texts as Pinel in an air which was published in his first Recueil d'airs nouveaux sérieux et à boire in 1729. The air is 'Lors que l'on boit à mes amours', and Bousset provides no more evidence as to the identity of the text's author, than Julie Pinel does. The

\footnotetext{
${ }^{3}$ Catherine E. Gordon-Seifert, Musical Voices of Early Modern Women (Aldershot Hants, England: Burlington, VT: Ashgate, 2005), p.148.

${ }^{4}$ Gordon-Seifert, 2005, pp.147-148.

5 'All the words in the collection, except for those which are in the names of M.rs, are by the same author as the music.' Pinel, 1737.
} 
fact that he set the same verse eight years earlier than Pinel indicates that not all of her texts were recently written.

Looking at the poems Pinel set to music, it is clear that she could equally write airs sérieux and airs à boire, there being sixteen examples of the first and thirteen examples of the latter. Her literary ability is further showcased in the cantatille and scène pastorale, the verse of which was also written by her.

Figure 2 Chart of air type and author of each piece in Pinel's Nouveau recueil.

\begin{tabular}{|c|c|c|c|}
\hline$\#$ & Title & Air type & Author \\
\hline 1 & Printems & Air sérieux & Pinel, Julie \\
\hline 2 & Mes yeux, ne versez plus de pleurs & Air sérieux & Pinel, Julie \\
\hline 3 & Echos indiscrets, taisez vous & Air sérieux & Pinel, Julie \\
\hline 4 & Funeste ennemy de la paix & Air sérieux & Paroles de Mr... \\
\hline 5 & Amans constans & Air à boire & Pinel, Julie \\
\hline 6 & Ruisseaux suspendez vôtre cours & Air sérieux & Pinel, Julie \\
\hline 7 & De la philosophie & $\begin{array}{l}\text { Air à boire>récit de Basse } \\
\text { Taille }\end{array}$ & Les paroles sont de Mr... \\
\hline 8 & Les charmes de l'indifférence & Air sérieux & Pinel, Julie \\
\hline 9 & Mon cher troupeau & Air sérieux>brunette & Pinel, Julie \\
\hline 10 & Lors que l'on boit à mes amours & Air à boire & Paroles de M... \\
\hline 11 & Que Tircis est charmant & Air sérieux & Paroles anciennes \\
\hline 12 & Buvons Lucas & Air à boire duo & Paroles de Mr C... \\
\hline 13 & $\begin{array}{l}\text { Apres m'avoir formé plus } \\
\text { aimables chaines }\end{array}$ & Air sérieux & Paroles de Mr... \\
\hline 14 & Sombres lieux obscures forrets & Air sérieux & Pinel, Julie \\
\hline 15 & Scène Pastorale & Scène Pastorale & Pinel, Julie \\
\hline 16 & Musette pour un berger & Air sérieux & Pinel, Julie \\
\hline 17 & Musette pour une bergere & Air sérieux & Les paroles sont de Mr... \\
\hline 18 & Tendres amans qu'amour engage & Air sérieux & Les paroles sont de Mr... \\
\hline 19 & Amans qui languissez & Air à boire>récit de Basse & Pinel, Julie \\
\hline 20 & Buvons tous à la ronde & Air à boire $>$ fanfare & Pinel, Julie \\
\hline 21 & Boccages frais & Air sérieux>brunette & Les paroles sont de Mr.*** \\
\hline 22 & Célimeine à changé & Air à boire à deux Voix Egales & Pinel, Julie \\
\hline 23 & Pourquoy le berger qui m'engage & Air sérieux duo>brunette & Pinel, Julie \\
\hline 24 & Trop longtems à Bacchus & Air à boire duo & Les paroles sont de Mr... \\
\hline 25 & Le Printems & Cantatille & Pinel, Julie \\
\hline 26 & Que les Mortels sont misérables & Air à boire>récit de Basse & Pinel, Julie \\
\hline 27 & $\begin{array}{l}\text { De richésses amy je ne suis point } \\
\text { jaloux }\end{array}$ & Air sérieux & Les paroles sont de Mr... \\
\hline 28 & $\begin{array}{l}\text { Pour guérir sans retour la vive } \\
\text { bléssure }\end{array}$ & Air à boire>récit de Basse & Paroles da même \\
\hline 29 & $\begin{array}{l}\text { Dieu du vin quelle est donc ta } \\
\text { fatalle puissance }\end{array}$ & Air à boire & Pinel, Julie \\
\hline 30 & Ah que l'homme est sçavant & Air à boire>récit de Basse & Pinel, Julie \\
\hline 31 & L'autre jour pres d'un bosquet & Air à boire>vaudeville & Pinel, Julie \\
\hline
\end{tabular}


The themes of the poems in this collection mostly adhere to those typically found in eighteenth-century airs, with the serious airs idealising nature and lamenting the troubles of love. Most of the drinking airs characteristically celebrate wine and love, or mourn the troubles of love with wine. Airs such as these have very short formal structures, in which authors had to portray setting, characters and context, usually with some sort of climax and resolution as well. To do so, many poets used allusion and symbolism, assuming that the audience had some knowledge of classical mythology. ${ }^{6}$

The majority of the airs in Pinel's collection are written in first-person narrative; however, there are some which are written in third-person narrative. ${ }^{7}$ The airs written in third-person narrative are chorus-like, each providing some advice about love, whether in celebration or in warning. Pinel's collection is also a perfect example of Gordon-Seifert's description of the change in gender representation in airs. Only one third of the airs have a male poetic voice:

Figure 3 Airs with a male poetic voice.

\begin{tabular}{|l|l|l|}
\hline Air & Air type & Reason for male poetic voice \\
\hline De la philosophie & Air à boire & Récit de Basse Taille \\
\hline $\begin{array}{l}\text { Lors que l'on boit à } \\
\text { mes amours }\end{array}$ & Air à boire & $\begin{array}{l}\text { Text refers to Silvie suggesting a male } \\
\text { poetic voice }\end{array}$ \\
\hline Buvons Lucas & Air à boire & Duo for Dessus and Basse \\
\hline Musette pour un berger & Air sérieux & Title indicates this: for a shepherd \\
\hline Amans qui languissez & Air à boire & Récit de Basse \\
\hline Buvons tous a la ronde & Air à boire & $\begin{array}{l}\text { Text refers to Iris suggesting a male poetic } \\
\text { voice }\end{array}$ \\
\hline Célimeine à changé & Air à boire & à deux Voix égales \\
\hline $\begin{array}{l}\text { Trop longtems a } \\
\text { Bacchus }\end{array}$ & Air à boire & Duo for Dessus and Basse \\
\hline $\begin{array}{l}\text { Que les mortels sont } \\
\text { misérables }\end{array}$ & Air à boire & Récit de Basse \\
\hline $\begin{array}{l}\text { Pour guérir sans retour } \\
\text { la vive bléssure }\end{array}$ & Air à boire & Récit de Basse \\
\hline $\begin{array}{l}\text { Ah que l'homme est } \\
\text { sçavant }\end{array}$ & Air à boire & Récit de Basse \\
\hline
\end{tabular}

\footnotetext{
${ }_{7}^{6}$ Niklaus, 1970, p.72.

7 These include the airs à boire 'Amans constans' (Catalogue no. 5. Volume II, p.11) and 'Amans qui languissez' (Catalogue no. 19. Volume II, p.40), and the air sérieux, 'Tendres amans qu'amour engage' (Catalogue no. 18. Volume II, p.39).
} 
The table above shows that the airs with a male poetic voice are either récits de basse, or duos, or the text indicates that the protagonist is a male regardless of vocal register. Otherwise, a female poetic voice dominates this collection, and they are not just those written by Pinel. Two of the texts by anonymous authors are clearly written for a female singer, 'Que Tircis est charmant ${ }^{8}$ and 'Boccages frais'. ${ }^{9}$ For those texts which could be sung by either a male or a female, Pinel has set every air (except for the récits de basse) for a soprano voice, making it clear that overall, the female character governs this collection.

\section{AIRS SERIEUX}

The table below provides an overview of the variety of line lengths found in Pinel's airs sérieux:

Figure 4 Chart of line lengths found in Pinel's airs sérieux.

I: length of the verse

II: number of syllables in the line

\begin{tabular}{|c|c|c|}
\hline Airs sérieux & $\mathbf{I}$ & II \\
\hline Printems & 12 & 1288810881281088 \\
\hline $\begin{array}{l}\text { Mes yeux, ne versez plus de } \\
\text { pleurs }\end{array}$ & 12 & 888108881288810 \\
\hline Echos indiscrets, taisez vous & 11 & 81281212121010888 \\
\hline Funeste ennemy de la paix & 8 & 812106810128 \\
\hline $\begin{array}{l}\text { Ruisseaux, suspendez vôtre } \\
\text { cours }\end{array}$ & 10 & 888681212101012 \\
\hline Les charmes de l'indifférence & 31 & $\begin{array}{l}10888810888810881212108888108 \\
1071388108108\end{array}$ \\
\hline Mon cher troupeau & 4 & 108812 \\
\hline Que Tircis est charmant & 5 & 12126812 \\
\hline $\begin{array}{l}\text { Apres m'avoir formé plus } \\
\text { aimables chaines }\end{array}$ & 4 & 12121212 \\
\hline Sombres lieux obscures forrets & 10 & 8121212121012121210 \\
\hline Musette pour un berger & 23 & 887886861277888887888777 \\
\hline Musette pour une bergere & 20 & 45454545566555555555 \\
\hline $\begin{array}{l}\text { Tendres amans qu'amour } \\
\text { engage }\end{array}$ & 8 & 812810810108 \\
\hline Boccages frais & 16 & 8121212121210121012121212121012 \\
\hline $\begin{array}{l}\text { Pourquoy le berger qui } \\
\text { m'engage }\end{array}$ & 12 & 888888888888 \\
\hline $\begin{array}{l}\text { De richésses amy je ne suis } \\
\text { point jaloux }\end{array}$ & 10 & 66668661266 \\
\hline
\end{tabular}

${ }^{8}$ Catalogue no. 11. Volume II, p.20.

${ }^{9}$ Catalogue no. 21. Volume II, p.43. 
Generally speaking, the shorter the line, the faster it is, and found in Pinel's collection are some lines made up of four syllables which are rare and are suitable for fleeting pieces of a light nature. ${ }^{10}$ This line type can be used on its own or be joined with others and Pinel combines it with lines of five syllables in 'Musette pour une bergere'. ${ }^{11}$ These short lines complement the light-heartedness of the musette genre, however, these particularly short lines which make up 'Musette pour une bergere' are rarely encountered in airs, providing an unusual aspect of Pinel's writing.

Also encountered is the six-syllable line, which seldom goes alone, uniting with line types of a different measure which is usually the longer, more preferred alexandrine, as is observed in the air sérieux, 'De richésses amy je ne suis point jaloux'. ${ }^{12}$ Further examples of this line type will be discussed later in this chapter under airs à boire. Lines made up of seven syllables often act as substitutes for lines with eight syllables, but they are less regulated. They have a lively and offhand pace, which gives the text boldness without removing any of its charm. ${ }^{13}$

One of the most common line types in this collection is the octosyllable, or line of eight syllables. ${ }^{14}$ It is clear from the table above that many of Pinel's airs include lines of this length, always combined with other types, except for 'Pourquoy le berger qui m'engage', ${ }^{15}$ which contains twelve lines with eight syllables in each. The airs exhibiting this line type are predominantly pastoral airs, appropriate for the simplicity propounded in their texts, which will be discussed further subsequently.

Before the advent of alexandrine, lines made up of ten syllables, the decasyllable, were the heroic verse-type. Over time it became associated with lighter poetry,

\footnotetext{
${ }^{10}$ Jean Suberville, Histoire et théorie de la versification française (Paris: L'École, 1946), p.138.

${ }^{11}$ Catalogue no. 17. Volume II, p.37.

${ }^{12}$ Catalogue no. 27. Volume II, p.68.

${ }^{13}$ Suberville, 1946, pp.134-5.

${ }^{14}$ 'Le vers de huit syllabes est, semble-t-il, le premier en date des vers français. Il est de très vieille noblesse...Il est bon pour tous les genres, comme l'alexandrin, dont il n'a pas toutefois l'ampleur.' (The line of eight syllables is, it seems, the earliest French line. It is from very old nobility [...] It is suitable for all genres, as is the alexandrine, but without its fullness). Suberville, 1946, p.133.

${ }^{15}$ Catalogue no. 23. Volume II, p.50.
} 
stories and songs. ${ }^{16}$ There are various examples of the decasyllable in Pinel's collection and it is always combined with other line types; namely the alexandrine and the octosyllable. For example, 'Printems ${ }^{\text {,17 }}$ and 'Echos indiscrets taisez vous ${ }^{18}$ display this arrangement. These airs also include the alexandrine, a line type pervading this collection: 'L'alexandrin s'appelle encore hexamètre ou vers de six pieds [...] On le nomme encore vers heroïque parce qu'il a d'abord servi à chanter les héros [...] En série, l'alexandrin a grande allure, il est propice au style soutenu et marie admirablement la plénitude du sens avec la plénitude du son' ${ }^{19}$ The use of the alexandrine throughout Julie Pinel's collection is imitative of high-style poetry, and those that do include this line type have more weighty sentiments, evident from their titles alone. For example, the term 'funeste' in the air sérieux 'Funeste ennemy de la paix ${ }^{20}$ is a poetic word usually found in highstyle poems.

Let us now turn to the subject matter of the airs sérieux in Pinel's Nouveau recueil. Of the seventeen airs sérieux, ten have a pastoral theme and within that are various sub-groups, all of which are discussed below.

\section{Involuntary love}

The first air in the collection, 'Printems', whose text is written by Pinel, employs a female poetic voice. This air sérieux displays a pastoral theme alongside that of involuntary love, being set in spring and inspired by love. A nightingale is personified in the poem, and this is reflected in the music which will be discussed in the following chapter. This text portrays a woman who is dependent on a man, with the middle verse of the air depicting the singer lamenting that her feelings are involuntary. 'Alas' indicates that in spite of herself, she is still in love:

Mon coeur hélas est aussy la victime

\footnotetext{
${ }^{16}$ Suberville, 1946, p.131.

${ }^{17}$ Catalogue no. 1. Volume II, p.1.

${ }^{18}$ Catalogue no. 3. Volume II, p.8.

19 The alexandrine is also called hexamètre [...] They still name it heroic verse because it first served for singing about heroes [...] In a series, the alexandrine has great allure, it is advantageous for the sustained style and it marries the fullness of sense to the fullness of sound. Suberville, 1946, pp.129-130.

${ }^{20}$ Catalogue no. 4. Volume II, p.10.
} 
Du Dieu que célébrant vos chans. ${ }^{21}$

Pinel's recueil continues with this theme, with her following two airs sérieux also presenting women who cannot help their adoration for a man. The singer of 'Mes yeux, ne versez plus de pleurs' is only consoled with the return of her loved one, Tircis: ${ }^{22}$ 'Mes yeux, ne versez plus de larmes./Tircis vient finir mes malheurs... ${ }^{23}$ Similarly, an inability to control one's feelings is highlighted in 'Echos indiscrets taisez vous':

Echos indiscrets, taisez vous,

N'allez pas répetter le nom de ce que j’aime.

Les Dieux mêmes seroient jaloux ${ }^{24}$

In this air, the singer is obviously outdoors, under the control of love and she is trying to tell herself not to keep repeating her vows of love. Throughout these airs, each woman is willing herself to feel and act differently, with little success as is once again highlighted in 'Pourquoy le berger qui m'engage', in which the poet expresses despair over a fickle lover and her inability to adopt the same fickle attitude as him:

Vole Amour, et me rends volage.

En vain je ressens cet outrage;

Mon coeur n'est pas moins amoureux:

L'ingrat peut bien romper ses noeuds,

Mais je ne puis être volage. ${ }^{25}$

\section{Love is scorned/sorrows of love}

Reliance on the love of a man does not pervade every air sérieux, however. In fact, in some, love is looked upon as the enemy. The best example of this is 'Les charmes de l'indifférence' in which peace, rest and indifference are alluded to in florid language, whereas love and Cupid are scorned.

Charmant repos, paisible indifférence,

Que votre empire a de douceur!

Vos plaisirs font tout mon bonheur.

Et jamais sous votre puissance

${ }^{21}$ My heart, alas, has also fallen victim/Of that God whom you celebrate in song. Pinel, 'Printems', (1737). Catalogue no. 1. Volume II, p.1.

22 The character found in this poem, Tircis, is found frequently in seventeenth century literature concerned with love, particularly in airs sérieux.

${ }^{23}$ My eyes, do not shed tears any more./Tircis comes to end my misfortunes. Pinel, 'Mes yeux ne versez plus de pleurs', (1737). Catalogue no. 2. Volume II, p.6.

${ }^{24}$ Be still, indiscreet echoes,/Do not repeat the name of my beloved./The Gods themselves would be jealous. Pinel, 'Echos indiscrets taisez vous', (1737). Catalogue no. 3. Volume II, p.8.

${ }^{25}$ Fly Love, come and make me fickle./In vain I feel this insult;/My heart is no less in love:/The ingrate may very well break his bonds,/But I cannot be fickle. Pinel, 'Pourquoy le berger qui m’engage', (1737). Catalogue no. 23. Volume II, p.50. 
L'on n'entend soupirer un coeur, ${ }^{26}$

The contrast of the beautiful language employed by Pinel to describe indifference compared with the description of love as the cause of tears and terrible pain indicates that the vocalist is bitter because of a bad experience with love.

Included in this collection are two epigrammatic airs sérieux which lament the sorrows of love, cautioning lovers to remain patient in the trials of love. The epigram was described by the poet Bauderon de Sénécé in 1717 as the ultimate of all the minor poetic forms:

Nous avons plusieurs especes d'Epigrammes, qui sous des noms differents, reviennent toutes à la même chose; car enfin nos chansons, soit galantes, soit bachiques, où du consentement même des étrangers la nation françoise excelle sur toutes les autres, \& nos Madrigaux, où les sentimens du coeur s'expriment si délicatement, qu'est-ce autre chose à votre avis, que des manieres d'Epigrammes....? ${ }^{27}$

An epigram is defined as 'a short poem ending in a witty or ingenious turn of thought, to which the rest of the composition is intended to lead. ${ }^{28}$ An epigram acts like a chorus giving advice. Both airs, 'Que Tircis est charmant' and 'Apres m'avoir formé plus aimables chaines', are short and have anonymous authors. The character Tirics appears again in the first epigram:

Que Tircis est charmant, et qu'il est amoureux;

Il me rend mille soins dont je suis allarmée.

Ah, qu'il est dangereux

Quand on est tendrement aimée,

De sentir qu'un amant est digne d'être heureux. ${ }^{29}$

The final lines warn against the dangers of love. The pain of love is equally revealed in the second epigram:

\footnotetext{
${ }^{26}$ Charming rest, peaceful indifference/How sweet is your empire!/Your pleasures are all my happiness./And never under your power/Does a heart sigh. Pinel, 'Les charmes de l'indifference', (1737). Catalogue no. 8. Volume II, p.15.

${ }^{27}$ We have several types of epigramme, which under different names, all come to the same thing; for when all is said and done, our songs, whether galant or drinking, about which even foreigners agree that the French nation excels above all others, and our madrigals, where the feelings of the heart are so nicely expressed, what are they in your view, but epigrammes...? Bauderon de Senecé, “Dissertation sur la composition de l'épigramme”, Épigrammes et autres pièces de M. de Senecé premier valet de chambre de la feue Reine, avec un traité sur la composition de l'épigramme, Paris, Giffart, 1717, p. l cited by Greer Garden, 'Variations d'un reçu: Les airs de Desmarest publiés dans le Recueil d'airs sérieux et à boire de Ballard'. Henry Desmarest (16611741) Exils d'un musicien dans l'Europe du Grand Siècle. Mardaga: 2005, 2005, p.357.

28 'Epigram.', Oxford English Dictionary Online, available from http://dictionary.oed.com.helicon.vuw.ac.nz/ accessed 20 March 2008.

${ }^{29}$ How charming Tircis is, and how loving;/He renders me a thousand services which have me worried./Ah, how dangerous it is/When one is tenderly loved,/To have the feeling that a lover is worthy of being happy. Pinel, 'Que Tircis est charmant', (1737). Catalogue no. 11. Volume II, p.20.
} 
Apres m'avoir formé les plus aimables chaines, L'amour livre mon coeur aux plus cruels soupirs: Ah si ses doux plaisirs sont oublier ses peines Ses tourmens ne font pas oublier ses plaisirs. ${ }^{30}$

The sorrows of love are also made known in 'Tendres amans qu'amour engage' whose text was written by an unidentified author. However, unlike the previous airs exhibiting this theme, 'Tendres amans qu'amour engage' is less bitter and instead presents a sophisticated view of love written in third-person narrative, which presents the maxim of the poem at the beginning, 'Tendres amans qu'amour engage,/Craignez de voir trop tôt courronner vos désirs; ${ }^{31}$ asserting that lovers should not yield to love too quickly, and to be careful.

\section{Pastoral themes}

Pastoral themes enjoyed a revival in the second half of the seventeenth century, particularly within polite society. Their prevalence can be observed in many French genres: novels, airs, part-songs, ballets and masquerades. ${ }^{32}$ Pastoral literature idealises the countryside by projecting back to the mythical age or by idealising it as a place of plenty, sensuality and happiness. There are also generic figures associated with the pastoral ideal, for example shepherds and shepherdesses, being representative of a golden age or utopia. ${ }^{33}$

The two musettes included in Pinel's collection exhibit this. The first, 'Musette pour un berger' is written by Pinel and immediately following this is a second musette, entitled 'Musette pour une bergere', and its text is written by an anonymous author. The subjects of the musette texts complement each other. In each, a penchant for simplicity can be observed. The musette, a rustic instrument, symbolised such thinking and the name of the instrument was transferred to airs that imitated the instrument's drone. Unusually for the genre, in the first and

\footnotetext{
${ }^{30}$ Having formed for me the most loving bonds,/Cupid delivers my heart to the cruellest sighs:/Ah if his sweet pleasures make one forget his sorrows/His torments do make one forget his pleasures. Pinel, ‘Apres m’avoir formé plus aimables chaines’, (1737). Catalogue no. 13. Volume II, p.23.

${ }^{31}$ Tender lovers that love binds,/Do not try to see your desires fulfilled too soon; Pinel, 'Tendres amans qu'amour engage', (1737). Catalogue no. 18. Volume II, p.39.

${ }^{32}$ L. Auld, 'The Pastoral Ploy in Nascent French Opera', French Musical Thought 1600-1800, edited by G. Cowart (London: U.M.I Research Press, 1989), pp.58-59.

${ }^{33}$ Auld, 1989, pp.58-59
} 
third musettes, a contrast is made between a pastoral lifestyle, and the pomp and grandeur of cities and royal courts: ${ }^{34}$

La paix qui regne en nos aziles

Nous assure un parfait bonheur;

Nous fuyons le bruit des villes,

La pompe des Rois nous fait peur: ${ }^{35}$

Douce innocence

régne sur nos coeurs

Chere ignorance

des biens séducteurs.

Ta jouissance

conserve nos moeurs,

Et l'espérance

des vaines grandeurs

N'a point de puissance, ${ }^{36}$

The pastoral ideals of simplicity are reflected in the musical setting of each text which will be discussed in the following chapter. Of course, the fashionable pastoral theme was idealisation rather than reality, and people did not really wish to abandon the splendour of court and salon life. Rather, it provided an opportunity for people to escape their everyday lives by pretending to be shepherds and shepherdesses in salons and private residences.

The pastoral air 'Boccages frais' employs vocabulary that is typical of this genre, such as 'oiseaux' (birds), 'fontaines' (springs) and 'musette'. The rhyme scheme is very simple, using rhyming couplets throughout:

Mais je l'entens chanter sur sa Musette,

Le moment fortunez qui luy rend sa Lisette,

J'apperçois son troupeau déja je vois son chien

Pour garder nos moutons se joindre avec le mien: ${ }^{37}$

This air is a brunette which was a very popular genre in late seventeenth and eighteenth-century France, characterised by tender sentiments. ${ }^{38}$ The text is very similar to 'Printems' in the way the delights of nature allows the vocalist to

\footnotetext{
${ }^{34}$ Auld, 1989, p.60.

${ }^{35}$ The peace which reigns in our retreat/Assures us a perfect happiness;/We escape the noise of cities,/The pomp of Kings frightens us: Pinel, 'Musette pour un berger,', (1737). Catalogue no. 16. Volume II, p.34.

${ }^{36}$ Sweet innocence/rules over our hearts/Dear ignorance/of seductive things./Taking pleasure in you/keeps our morals safe/And longing/for empty grandeur/Has no power. Pinel, 'Musette pour une bergere', (1737). Catalogue no. 17. Volume II, p.37.

${ }^{37}$ But I hear him singing with his musette,/Of the fortunate moment that brings back his Lisette,/I see his flock, I see his dog/To protect our sheep, now join with mine. Pinel, 'Boccages frais', (1737). Catalogue no. 21. Volume II, p.43.

${ }^{38}$ David Tunley, 'Brunette', Grove Music Online ed. L. Macy (Accessed 16 March 2008), http://www.grovemusic.com.
} 
express her love and happiness. Unfortunately, the man she loves is enamoured of another person, named Lisette, and it is the protagonist's hope that he will surrender to her desire through her mediation of the birds:

Amour hâte ses pas, que l'espoir le plus tendre

A mes ardens desirs, le presse de se rendre

Charmans oiseaux redoublez vos concerts,

Et que de nos plaisirs retentissent les airs. ${ }^{39}$

\section{Shocking imagery}

Pinel's collection includes the occasional use of very forceful, strong terms which warrant mention. The poems cited are here are imitating the language of high-spoken tragedy, which was usually seen on the French classical stage.

The first example is found in the first air, 'Printems', written by Pinel:

Mon coeur hélas est aussy la victime

Du Dieu que célébrent vos chans.

Mais pour moy ce seroit un crime

De laisser éclatter les feux que je ressens. ${ }^{40}$

The rhyming terms ‘crime’ and ‘victime’ are strong words, both of which appear in the middle verse which invokes violence. Similar shocking imagery is conjured in 'Funeste ennemy de la paix'. This is the first air in Pinel's collection attributed to an unidentified author:

Funeste ennemy de la paix,

Autheur de mes tristes allarmes,

Perfide Amour,

Tu ne te plais qu'à voir verser du sang,

A voir couler des larmes. ${ }^{41}$

The word 'sang' (blood) is shocking, particularly because no line provides a matching rhyme for it and thus it stands out on its own. The graphic imagery in these two airs heightens the bitter and resentful attitude towards love that is being expressed.

\footnotetext{
${ }^{39}$ Love hastens his steps, that the most tender hope may/Press him to surrender to my ardent desires./Charming birds, sing again your songs,/And let the sighs of our pleasures resound. Pinel, 'Boccages frais', (1737). Catalogue no. 21. Volume II, p.43.

${ }^{40}$ My heart, alas, has also fallen victim/Of that God whom you celebrate in song/But for me it would be a crime/To give expression to the fires of passion I am feeling. Pinel, 'Printems', (1737). Catalogue no. 1. Volume II, p.1.

${ }^{41}$ Fateful enemy of peace,/Author of my sad fears,/Treacherous Cupid,/You take delight only in seeing blood shed,/And in seeing tears flow. Pinel, 'Funeste ennemy de la paix', (1737). Catalogue no. 4. Volume II, p.10.
} 


\section{AIRS À BOIRE}

The following table gives an overview of verse forms and the variety of line lengths found in Pinel's airs à boire:

Figure 5 Chart of line lengths found in Pinel's airs à boire.

\begin{tabular}{|l|c|l|}
\hline Airs à boire & I & II \\
\hline Amans constans & 9 & 888668888 \\
\hline De la philosophie & 8 & 61212612121212 \\
\hline $\begin{array}{l}\text { Lors que l'on boit à mes } \\
\text { amours }\end{array}$ & 6 & 8128888 \\
\hline Buvons Lucas & 7 & 888121088 \\
\hline Amans qui languissez & 11 & 1281288888866 \\
\hline Buvons tous à la ronde & 12 & 666866686668 \\
\hline Célimeine à changé & 13 & 6688666666668 \\
\hline Trop longtems à Bacchus & 6 & 1288101212 \\
\hline $\begin{array}{l}\text { Que les mortels sont } \\
\text { misérables }\end{array}$ & 8 & 881012128812 \\
\hline $\begin{array}{l}\text { Pour guerir sans retour la } \\
\text { vive bléssure }\end{array}$ & 8 & 1212888886 \\
\hline $\begin{array}{l}\text { Dieu du vin qu'elle est donc } \\
\text { ta fatalle puissance }\end{array}$ & 10 & 1212128121210888 \\
\hline Ah que l'homme est sçavant & 9 & 12121212121012108 \\
\hline $\begin{array}{l}\text { L'autre jour pres d'un } \\
\text { bosquet }\end{array}$ & 30 & 7878787877787877 \\
\hline
\end{tabular}

\section{The pleasures of wine}

The texts of the thirteen airs à boire in this collection are fairly typical, as was mentioned at the beginning of this chapter. The early airs à boire in the collection celebrate love through drinking wine, and show that the pleasures of love and wine can exist in harmony.

Pinel's first air à boire, 'Amans constans', urges constant lovers to 'drink up' in celebration of their love. This theme continues through the second air à boire, 'De la philosophie', written by an anonymous author, in which Bacchus and Silvie are witness to the theories expressed by the author of the text:

Pour braver du destin les biseares decrets

Le vin sçait me donner un courage invincible;

Et je ne connois point de plaisir plus sensible

Que de suivre l'Amour quand il lance ses traits. ${ }^{42}$

\footnotetext{
${ }^{42}$ To defy the strange decrees of destiny/Wine can give me an invincible courage/And I know no keener pleasure/Than to follow Cupid when he throws his arrows. Pinel, 'De la Philosophie', (1737). Catalogue no. 7. Volume II, p.14.
} 
In the case of this récit de basse-taille, wine furnishes the poet with the courage to pursue Cupid and love. It is made up of lines that combine the alexandrine with the hexasyllable, thus providing an example of the way six-syllable lines can be used poetically.

Elisabeth Jacquet de la Guerre's airs à boire display similar themes. 'La Provençale', is one such air that celebrates the pleasures of wine and love equally and harmoniously:

Mon coeur en buvant

Devient constant,

Et cette liqueur

Fait mon honheur;

À Bacchus

Ainsi qu'à Venus,

Faisons tour à tour

À tous deux la cour, ${ }^{43}$

This air is immediately followed with another drinking song entitled 'Suite de La Provençale' which continues this theme:

Quel plaisir charmant

Dans ce moment,

Nous pouvons en liberté

Choisir à nôtre gré,

Vin délicieux

De beaux yeux,

Et sans embarras

Nous jouissons de tant d'appas. ${ }^{44}$

In Pinel's fanfare, 'Buvons tous à la ronde', a wish is made for love and wine to last to the end of the world: 'Puisse autant que le monde/Durer ce vin et nos amours! ${ }^{45}$ In the first stanza, celebrations of love and wine co-exist, however by the poem's close, it becomes apparent that the vocalist has to choose one or the other. Love's object in this air is once again the character Iris who is named in the third stanza. The vocalist reveals that he is unable to remain faithful to Bacchus in light of love's temptation, and thus, Cupid wins:

Iris à cette table

Determine mon choix:

\footnotetext{
${ }^{43}$ My heart while drinking/Becomes constant,/And this liquor/Makes me happy;/To Bacchus/As well as to Venus/Let's by turns/Pay court to them both. Elisabeth Jacquet de la Guerre, 'La provençale', cited in Mary Cyr (ed.), Elisabeth-Claude Jacquet de La Guerre The Collected Works, Volume 4 (New York: The Broude Trust, 2005), p.xlvi.

${ }^{44}$ We can freely/Choose as we wish,/Delicious wine,/Beautiful eyes,/And without hindrance/We enjoy so many charms. Elisabeth Jacquet de la Guerre, 'Suite de la provençale', cited in Cyr, 2005, p.xlvi.

${ }^{45}$ May as long as the world/This wine and our loves last! Pinel, 'Buvons tous à la ronde', (1737). Catalogue no. 20. Volume II, p.42.
} 
Que sa voix adorable

Amour-met de coeurs sous tes loix. ${ }^{46}$

The next air à boire in Pinel's collection, 'Buvons Lucas', written by 'Mr C.' is a much more straightforward and simple drinking song. It is just about drinking, providing us with a light, humorous air. There is no mention of love at all, but rather, an ambition to drink as much as possible on the parts of Lucas and Gregory, who are characters commonly portrayed as drunkards in drinking songs. $^{47}$

\section{Sorrows in Bacchic texts}

During the course of Pinel's collection, the mood of the airs à boire becomes more sorrowful. Love is being viewed and portrayed as an enemy and rival to the pleasures of wine and Bacchus. This is typically found in drinking songs from the eighteenth century. For example, Jacquet de la Guerre’s air à boire, 'Parodie, sur la bourée de Cephale et Procris’, paints an inconstant lover who would much prefer to ‘swig wine all day long' rather than submit to love's torments:

\footnotetext{
Mais si tu jase jamais

Ny d'amour, ny d'aucun de ses traits.

D'une pinte à l'instant bel et biau

Je jurons de te casser le Musiau. ${ }^{48}$
}

The language in this particular air is vulgar and peasantry, however, Pinel's airs à boire are not written with the same vulgar tone.

Pinel's 'Amans qui languissez' is the first example of an air à boire which presents love and wine as mutually exclusive. Unlike the epigram, in this air the maxim appears in lines three and four:

\footnotetext{
Amans qui languissez sous de pesantes chaînes

Redoublez vos soins, vos soupirs;

Essayez de fléchir des rigueurs inhumaines, Pour arriver aux vrais plaisirs: ${ }^{49}$
}

\footnotetext{
${ }^{46}$ Iris at this table/Determines my choice:/What a lot of hearts/Her lovely voice puts under your sway, Cupid. Pinel, 'Buvons tous a la ronde’, (1737). Catalogue no. 20. Volume II, p.42.

47 The drunkard 'Grégoire' was also commonly used in music by Desmarest, Sicard and Debuisson. Greer Garden, 'Variations d'un style reçu: Les airs de Desmarest publiés dans le Recueil d'airs sérieux et à boire de Ballard', Henry Desmarest (1661-1741) Exils d'un musicien dans l'Europe du Grand Siècle (Mardaga: 2005), pp.362-364.

${ }^{48}$ But if you ever chatter/Either about love or any of his darts,/With a pint immediately/I swear I will break your neck. Elisabeth Jacquet de la Guerre, 'Parodie, sur la bourée de Cephale et Procris', cited in Cyr, 2005, p.xlv.
} 
Her text urges lovers to maintain constancy and expressions of love in order to arrive at true happiness. Musically, this coincides with the end of the ' $A$ ' section and the text continues for another seven lines. However, the second half of the air consoles that one can turn to wine and to Bacchus should one's love and constancy be laughed at and rejected. The final two lines of this air provide an example of Pinel's unique authorship: 'Que sur un rouge bord/Ils fassent tous naufrage! ${ }^{50}$ The English translation, 'Red rim', is here referring to red wine and this realistic detail is very unusual in this kind of text. The poem's final line makes for a very desolate and miserable ending.

A bitter attitude towards love is propounded in 'Trop longtems à Bacchus', whose text is written by an anonymous poet. It describes an internal struggle over love and Bacchus in which the vocalist's references to love are scornful: 'Si ce Dieu, devenu vainqueur,/Sur le cruel amour remporte la victoire' ${ }^{51}$ The 'disastrous enemy' from the final line is another allusion to love which threatens peace and repose in life. By the end of the air, the initial struggle between love and wine has clearly been won by Bacchus to whom the poet swears allegiance.

'L'autre jour pres d'un bosquet', written by Pinel, is the final air in her collection. The titles given to this air are many: the contents page labels it a vaudeville, which were epigrammatic pieces that were popular in seventeenth and eighteenth-century France. ${ }^{52}$ These pieces were often set to well-known tunes; Pinel also included the title, 'Chansonette anacreontique' on the music. 'Chansonette' is a generic term that refers to a solo or ensemble vocal piece, in simple binary or da capo forms. 'Anacreontique' is the most unusual term applied to this air because it refers to a particular kind of poetry. Anacreontic

\footnotetext{
${ }^{49}$ Lovers who languish under heavy chains/Intensify your care, your sighs;/Try to bend inhuman rigour,/To arrive at true pleasures. Pinel, 'Amans qui languissez', (1737). Catalogue no. 19. Volume II, p.40.

${ }^{50}$ On a red rim/May they all be shipwrecked! Pinel, 'Amans qui languissez', (1737). Catalogue no. 19. Volume II, p.40.

${ }^{51}$ If this God, becomes victorious,/Wins a victory over cruel love. Pinel, 'Trop longtems à Bacchus', (1737). Catalogue no. 24. Volume II, p.53.

${ }^{52}$ Clifford Barnes, 'Vaudeville', Grove Music Online ed. L. Macy (Accessed 16 March 2008), http://www.grovemusic.com.
} 
poetry was about the simple pleasures of love and wine, described as frivolous texts which were in vogue throughout Europe for over three centuries. ${ }^{53}$

'L'autre jour pres d'un bosquet' adheres to the vaudeville type, being an epigrammatic air made up of five stanzas. The purpose of this poem is not clear until the final lines when it is discovered that the subject of the poem is Cupid, who tricks the vocalist:
Le traitre d'un ris moqueur
Décoche un trait et s'envole.
Le trait me perce le coeur
Mais toute plainte est frivole
Qui craint un semblable tour
Doit à jamais fuir l'amour. ${ }^{54}$

Cupid strikes the singer with love; however, this incident is not welcomed. Love is described as thieving and tricking: 'Il ravit ma liberté' ${ }^{55}$ No reason is given as to why the singer fears love, however, this completes the lineup of the other airs à boire in this collection that portray an aversion to love. The label 'Chansonette anacreontique' is thus unusual. This air does not celebrate the pleasures of love which is characteristic of anacreontic poetry. Rather, the opposite is true.

We move from viewing love as the enemy, to viewing wine as the enemy in Pinel's 'Dieu du vin'. It is clear from the first line of text that wine is not being celebrated as it is in the other airs à boire: 'Dieu du vin quelle est donc ta fatalle puissance, ${ }^{56}$ The protagonist is perturbed by the influence of wine on her love, Tircis. Pinel uses strong language to portray this, calling wine 'le funeste breuvage' and 'ce jus que j'abbhore'. ${ }^{57}$ The vocalist's misgivings are clear in the line 'Ne nous reste-t'il plus d'éspoir', which presents her complete loss of hope. ${ }^{58}$

\footnotetext{
${ }^{53}$ Marshall Brown, 'Passion and Love: Anacreontic Song and the Roots of Romantic Lyric', English Literary History, Vol. 66, no. 2, 1999, p.374.

54 The traitor with a mocking laugh/Fires an arrow and flies off./The arrow pierces my heart/But any complaint is frivolous/Whoever fears a similar trick/Must flee love for ever. Pinel, 'L'autre jour pres d'un bosquet', (1737). Catalogue no. 31. Volume II, p.74.

${ }^{55}$ He took away my freedom. Pinel, 'L'autre jour pres d'un bosquet', (1737). Catalogue no. 31. Volume II, p.74.

${ }^{56}$ God of wine what therefore is your fatal potency. Pinel, 'Dieu du vin quelle est donc ta falle puissance', (1737). Catalogue no. 29. Volume II, p.71.

57 'the disastrous beverage' and 'this juice which I loathe. Pinel, 'Dieu du vin quelle est donc ta falle puissance’, (1737). Catalogue no. 29. Volume II, p.71.

${ }^{58}$ Is there no more hope for us? Pinel, 'Dieu du vin quelle est donc ta falle puissance', (1737). Catalogue no. 29. Volume II, p.71.
} 


\section{Science}

Alongside the importance placed on the art of conversation in the eighteenth century, salon society took an amateur's interest in science and philosophy. Also prevalent in this period, was the continued significance of the pursuit of gold.

This was observed in literature also, and it became a common theme found in seventeenth- and eighteenth-century airs. The air à boire, 'Pour guérir sans retour la vive bléssure', whose text was written by an anonymous author, illustrates this. Medicine and doctors were popular subjects of parody, and the author calls upon wine as the remedy for the pain of love, which the poet refers to as the severest injury: 'mon coeur blessé des traits d'Aminte'. ${ }^{59}$ In this text, we also find a reference to a classical figure, Hippocrates, who was an ancient Greek physician, believed by many to be the founder and father of medicine. Hippocrates symbolises the remedial properties of wine, which is further reinforced by two other terms in this air: 'poison' (translated in English as 'antidote'), meaning a medicine which is given to counteract the influence of poison or disease; ${ }^{60}$ and 'élixir divin' which is an unusual choice of term, especially in the light of another air à boire text by Pinel which will be discussed next. 'Elixir' is a term which refers to an essence with the property of prolonging life indefinitely, and was a term used by alchemists. ${ }^{61}$

Alchemy is a form of chemistry from the Middle Ages and late Renaissance, a time in which attempts were made to transform base metals into gold. ${ }^{62}$ In literature, alchemy is used as a symbol of greed, corruption and deceit, and as a general metaphor for a materialistic, urban world. As well as the loose reference to alchemy in the air à boire discussed above, 'Ah que l'homme est sçavant' presents us with a particularly unusual air on this very topic. The text, by Pinel, clearly points to alchemy, through its basic description of the alchemic process:

L'on fixe le mercure on a beau me le dire, Dans un creuset je vois mettre de l'or,

\footnotetext{
59 my heart hurt by Aminta's shafts. Pinel, 'Pour guérir sans retour la vive bléssure', (1737). Catalogue no. 28. Volume II, p.70.

60 'Antidote', Oxford English Dictionary Online, available from http://dictionary.oed.com.helicon.vuw.ac.nz/ accessed 3 March 2008.

61 'Elixir, n.', Oxford English Dictionary Online, available from http://dictionary.oed.com.helicon.vuw.ac.nz/ accessed 3 March 2008.

62 'Alchemy', Oxford English Dictionary Online, available from http://dictionary.oed.com.helicon.vuw.ac.nz/ accessed 1 May 2008.
} 
Et de soufleur confus jamais ne l'en retire ${ }^{63}$

In particular, the materials 'le mercure' and 'l'or' reveal that we are dealing with an unusual topic in this poem, and the manner in which these materials are being 'worked on' is suggestive of transformation and alchemy.

In this air, we find the stock drunkard character, Gregory, who is dwelling on the futile endeavours of alchemy:

Ah que l'homme est sçavant, disoit un jour Grégoire,

Et que son sort me semble beau quand je le vois

Sur un fourneau travailler suivant un grimoire:

Apres mille travaux l'on ne voit rien encore. ${ }^{64}$

The subject of alchemy is also hinted at in the final line of the text, 'Mais je sçais soufler de bon vin'. ${ }^{65}$ The verb 'souffler' can refer to a number of things: glass blowing, and removing things in a mysterious manner. Here, 'souffler' takes on two meanings: Pinel is being humorous by mentioning the pleasures of drinking and by mocking the actions of alchemists. We may note a phrase found in Randle Cotgrave's Dictionarie of the French and English Toungues, 'Il souffle - he plays the Alchemist', ${ }^{66}$ further confirming the air's topic.

One might argue that Pinel ordered the airs in her collection specifically and coherently. For example, the airs à boire become progressively more sorrowful as the collection continues. This is with the exception of 'Buvon tous a la ronde' which celebrates love and wine being engaged in harmony, and which appears amongst the more sorrowful airs à boire.

\section{SCÈNE PASTORALE}

This work comprises dialogue and a concluding duo between the characters Daphné and Iphis as if it is to be staged. In it, they communicate their eternal and

\footnotetext{
63 Mercury is fixed in solid form, in vain do they tell me,/I see gold being placed in crucible,/Worked on reduced, but never bringing yield. Pinel, 'Ah que l'homme est sçavant', (1737). Catalogue no. 30. Volume II, p.73.

${ }^{64}$ Ah how learned is man, said Gregory one day,/And how his fate seems beautiful to me when I see him working at a stove/According to a book of magic/After a thousand endavours we still see nothing. Pinel, 'Ah que l'homme est sçavant', (1737). Catalogue no. 30. Volume II, p.73.

${ }^{65}$ But I can make good wine disappear. Pinel, 'Ah que l'homme est sçavant', (1737). Catalogue no. 30. Volume II, p.73.

${ }^{66}$ Randle Cotgrave, A Dictionarie of the French and English Toungues (London: Aadam Islip, 1611), www.pbm.com/ lindahl/cotgrave/.
} 
faithful love to each other. The style of writing is suitable for the dramatic genre, with numerous instances of the noblest versification, the alexandrine, which heightens the imitation of high-style poetry. The line types in Pinel's Scène Pastorale is outlined in the following table:

Figure 6 Chart of line lengths found in Pinel's Scène pastorale.

\begin{tabular}{|l|c|l|}
\hline Scène Pastorale & I & II \\
\hline Iphis & 13 & 10121081286688888 \\
\hline Daphné & 5 & 8881210 \\
\hline Iphis & 5 & 108121012 \\
\hline Daphné & 4 & 812812 \\
\hline Iphis & 4 & 89128 \\
\hline Daphné & 4 & 1212128 \\
\hline Iphis & 4 & 128108 \\
\hline Daphné & 4 & 10888 \\
\hline Iphis & 6 & 12121212128 \\
\hline Duo. Ensemble. & 4 & 8888 \\
\hline
\end{tabular}

The characters have no connection with a particular place in this piece. Rather, they are defined solely by their love for one another, adhering to pastoral poetry in which the characters are a shepherd and shepherdess, appealing to nature's beauty and simplicity.

This work displays a combination of drama and comedy. The drama stems from the exaggerated nature of Iphis’ lengthy, florid expression of adoration for his sweetheart Daphné, whereas the comedy arises from Daphné's teasing Iphis in which she makes reference to an imaginary lover, causing Iphis to despair at the thought that his love is not reciprocated:

\footnotetext{
Daphné: [...]

Hé, si quelqu'autre amant avoit reçeu ma foy

De quel succes votre flamme suivie?

Iphis:

Mon désespoir m'arracheroit la vie

Mais quel éffroy vient me saisir,

Quel est l'heureux rival qui prétend me ravir

L'unique objet qui receüs mon hommage, ${ }^{67}$
}

\footnotetext{
${ }^{67}$ Daphné : [...] Ah, if I had sworn my devotion to another lover/What success [would] your burning love [have had]?/Iphis: My despair would end my life/But what dread takes hold of me,/Who is this rival who claims to take from me/The unique object of my homage,/Ah let us quickly search for him without delay. Pinel, 'Scène pastorale', (1737). Catalogue no. 15. Volume II, p.26.
} 
Daphné clears up the misunderstanding and on Iphis' request, she declares 'une flâmme eternelle'. 68 'Flâmme' is a very elegant word meaning love, and is an elevated expression within the quasi-heroic language found in this work, in combination with Pinel's use of alexandrines.

Iphis' last solo verse is almost entirely made up of alexandrines, and this corresponds to the subject matter of the text at this point, which is the climax of the couples' florid exchange in which Iphis gives his oath of faithfulness to Daphné. In doing so, Iphis invokes Pâlés, an obscure deity of shepherds, flocks and livestock in Roman mythology. This reference to Pâlés and nature are symbolic of his oath to remain faithful, loyal and steadfast to Daphné:

J'en atteste ces lieux à Pâlés consacrez,
Ces bois de nos bergers en tous tems revérez,
Puissent ces arbres verds dépouillez de verdure
Ne reprendre jamais leur aimable parure
Puissent ces lieux charmans être d'affreux déserts
Si jamais je brise mes fers. ${ }^{69}$

The piece is full of charm and it alludes to the rusticity of shepherds by way of the exaggerated oaths, illustrated in the final two lines from Iphis' solo, cited above, 'May these charming fields be hideous deserts/If I ever break my vows'. The high-flowing language found here is usually reserved for serious French songs, and is not typical of pastoral poetry which uses simple verse.

The final duo of the Scène Pastorale adheres most strongly to the pastoral ideal where simplicity is favoured over grandeur:

Fuyons la grandeur souveraine,

Aimons, cédons à nos désirs,

Craignons l'éclat dans les plaisirs

Que nous prepare notre châine. ${ }^{70}$

The duo is written entirely in eight-syllable lines, which is one of the common line types and is thus representative of the simplicity that Daphné and Iphis are celebrating in their song.

\footnotetext{
${ }^{68}$ an eternal love. Pinel, 'Scène pastorale', (1737). Catalogue no. 15. Volume II, p.26.

${ }^{69}$ I swear to it by all that Pallas holds dear,/These woods [that] our shepherds forever revere,/May these green trees be stripped of their leaves/Never to bring back their lovely finery/May these charming fields be hideous deserts/If I ever break my vows. Pinel, 'Scène pastorale', (1737). Catalogue no. 15. Volume II, p.26.

${ }^{70}$ Let us flee all grandiose display,/Let us love each other and give in to our desires,/Let us fear the intensity that in [our] pleasures/Our chain prepares for us. Pinel, 'Scène pastorale', (1737). Catalogue no. 15. Volume II, p.26.
} 
Comparisons can be drawn between Pinel's Scène Pastorale and Jean-Baptiste de Bousset's Eglogue Bachique from 1695. These two works are very similar both poetically and musically. Like Pinel's pastoral work, Bousset's eglogue is a dialogue for two characters, Iris and Tircis, who express their adoration for one another in a dramatic and exaggerated manner, making reference to pastoral images and themes:

Avant que je cesse d'aimer la Beauté qui m’engage,

Les Poissons quitteront la Mer

Pour venir sur ce rivage: ${ }^{.1}$

The above oath can be compared to the final lines of Iphis' solo that are discussed earlier in which nature is referred to in order to convey one's passion and adoration. Furthermore, a moment of confusion ensues in Bousset's eglogue (like that which arises in Scène Pastorale when Daphné refers to an imaginary lover) when Iris declares herself unworthy of Tircis next to the beautiful Lisette. Once again, we find that the text becomes more exaggerated as the piece continues, particularly as Tircis makes every effort to convince Iris of his ardour.

It is possible that Pinel copied or imitated Bousset's work as a guide for her own pastorale given that not only is the text very similar, but the musical structure and style is comparable also.

\section{CANTATILLE}

Throughout the cantatille we find a mix of line types, including the alexandrine which appears in various lines in the final and air:

Figure 7 Chart of line lengths found in Pinel's cantatille.

\begin{tabular}{|l|c|l|}
\hline Cantatille & I & II \\
\hline Recitatif & 8 & 128888868 \\
\hline Air & 8 & 88888888 \\
\hline Recitatif & 12 & 8881212121066686 \\
\hline Air & 8 & 1012121210888 \\
\hline
\end{tabular}

The cantatille genre remained in vogue until mid-century, its texts described by Vollen as 'rococo ${ }^{72}$ presentations of light hearted texts'. ${ }^{73}$ Unlike Rousseau's

\footnotetext{
${ }^{71}$ Before I stop loving the Beauty who is committed to me,/Pisces will leave the Sea/To come ashore. Bousset, 'Eglogue Bachique’, (Paris: Ballard, 1731).
} 
description of the cantatille genre (quoted in chapter three), ${ }^{74}$ Pinel's cantatille, 'Le Printems', is an exciting mix of virtuosity and elegance, best summed up by the following quotation:

With the cultivation of the cantatille, the form moved decisively into its rococo phase, and by the middle of the century many works had been composed which, eschewing the dramatic, sought only to express the delicate. ${ }^{75}$

The personage named in this text is Iris, a serious character found in many drinking airs from this era, often as the object of love for men. The opening recitative and air of Pinel's cantatille celebrates the return of spring, responding to the beauty of nature through song and dance: 'Chantez, dansez jeunes bergères,/A l'ombre des ces frais ormeaux' ${ }^{76}$ The shepherds and shepherdesses are swept up by the season and inspired to celebrate their love which is blossoming alongside the season of spring. The pervading octosyllable in this recitative and air contributes to the pastoral theme and idea of simplicity in the text.

The second recitative reveals to us that there is a spirit of love in the air which has captured everything and everyone, apart from Iris, who is indifferent to the manifestation of love in this pastoral scene. Pinel presents a very passionate character in 'Le Printems' who is in love with Iris and interestingly, the alexandrine line type appears within the final recitative and air in combination with the intensifying passion of the text. The sweet song of the nightingales is summoned with the hope that it will inspire Iris to feel love as well.

Throughout 'Le Printems', Pinel invokes nature to describe love, and as in the Scène Pastorale, figures from classical mythology are referred to:

Le Zéphir va s’unir à Flore,

Bientost de leur tendres amours

Nous allons voir éclore

\footnotetext{
72 The term rococo is more commonly applied to a style of architecture from late seventeenth century France, however, it is also applied to eighteenth century French music. Many describe the concept of rococo in music as similar to the style 'galant'. Daniel Heartz \& Bruce Alan Brown, 'Rococo’, Grove Music Online ed. L. Macy (Accessed 28 February 2008), http://www.grovemusic.com.

${ }^{73}$ Vollen, 1982, p.16.

${ }^{74}$ See page 27 of this study.

${ }^{75}$ David Tunley, The Eighteenth Century French Cantata (London: Dennis Dobson, 1974), p.14.

${ }^{76}$ Sing and dance, young shepherdesses,/In the shade of these fresh young elm trees. Pinel, 'Le Printems’ (1737). Catalogue no. 25. Volume II, p.55.
} 
Mille fleurs avec les beaux jours... ${ }^{77}$

Firstly Pinel mentions 'le Dieu de jour', the God of daylight, and then introduces two other relatively minor figures: 'Zéphir', the Greek god of the west wind, and 'Flore', the Roman goddess of flowers, representing the season of spring. The season of spring and the mythological figures are symbolic of a relative state of happiness on the part of the protagonist. The connection between 'Zéphir' and 'Flore' is referred to as love which gives birth to the beauties of spring.

We find pastoral images once again in Pinel's cantatille, with the invocation of nature to describe love. The sweet nightingales and their song present an image commonly evoked in this type of text, however, Pinel uses an unusual word in relation to their song:

Que vos chants amoureux deviennent les présages

D'un plaisir qui me rend aussy content que vous. ${ }^{78}$

The term 'Présage' ('omen') means 'an event or phenomenon regarded as a portent of good or evil' and 'an indication of good or evil to come'. ${ }^{79}$ In the case of this air, 'omen' is a positive term because the vocalist wishes that the nightingales' song will persuade the character Iris to fall in love. The term 'présage' is still an ambiguous one and perhaps there is an underlying tone of illfortune due to Iris' continual indifference. Perhaps it was chosen for this very reason.

The selected cantatilles in the Garland Collection of Cantatas and Cantatilles by Louis Le Maire (c.1693-c.1750) ${ }^{80}$ would suggest that the subject in Le Printems is very typical. Many of Le Maire's cantatille texts contain pastoral themes such as birds whose songs and melodies are symbolic of love. Also seen in a number of the texts are shepherds and shepherdesses who are conquered by love, such as

\footnotetext{
${ }^{77}$ Zephyr will band together with Flora,/And soon from their tender love/We will see a thousand flowers/Blossom forth with the beautiful days... Pinel, 'Le Printems' (1737). Catalogue no. 25. Volume II, p.55.

${ }^{78}$ Let your amourous songs become omens/Of a pleasure that will make me just as happy as you are. Pinel, ‘Le Printems’ (1737). Catalogue no. 25. Volume II, p.55.

79 'Omen, n.', Oxford English Dictionary Online, available from http://dictionary.oed.com.helicon.vuw.ac.nz/ accessed 22 April, 2008.

${ }^{80}$ Louis Le Maire, Laurent Gervais, Nicolas Racot de Grandval and edited by David Tunley, Cantatas and cantatilles (New York: Garland, 1991).
} 
in Iris (1732), La Musette (1735), Themire (1738), and Les Plaisirs Champêtres (1743). 


\section{Chapter 6}

\section{The Music of Pinel's recueil}

Julie Pinel's Nouveau recueil d'airs sérieux et à boire contains sixteen airs sérieux and thirteen airs à boire for one or two voices. Most have a figured bass part, and one air sérieux includes an obbligato flute. Some of the airs are defined further with titles such as récit de basse, vaudeville, brunette and fanfare. Also included are a scène pastorale and a cantatille. A breakdown of her collection can be seen in the following chart:

Figure 8 Julie Pinel's Nouveau recueil d'airs sérieux et à boire (1737).

\begin{tabular}{|l|l|l|}
\hline 16 airs sérieux $\rightarrow$ & 3 brunettes $\rightarrow$ & 2 duos \\
\hline 13 airs à boire $\rightarrow$ & 2 musettes & \\
\hline & 5 récits & \\
\hline & 3 duos & \\
\hline & 1 vaudeville & \\
\hline 1 cantatille & 1 fanfare & \\
\hline 1 scène pastorale & & $=31$ pieces \\
\hline & & \\
\hline
\end{tabular}

This chapter will provide an overview of the remarkable variety that is found within her compositions, some of which is outlined in the chart below and which comprises most of the air types outlined by Tony Eastwood in his 1984 article 'The French Air in the Eighteenth Century: A Neglected Area'; namely, continuo accompanied solo songs; vocal duos; airs printed on one stave only; and récits de basse. ${ }^{1}$ These air types will be discussed in further detail throughout this chapter.

\footnotetext{
${ }^{1}$ Tony Eastwood, 'The French Air in the Eighteenth Century: A Neglected Area', Studies in Music, Vol. 18, 1984, pp.84-107.
} 
Figure 9 Overview of Pinel's Nouveau recueil.

\begin{tabular}{|c|c|c|c|c|c|c|}
\hline Air & $\mathbf{P}$ & First line of air & $\begin{array}{l}\text { Time } \\
\text { signa- } \\
\text { ture }\end{array}$ & Key & Scoring & Form \\
\hline \multirow[t]{16}{*}{$\begin{array}{l}\text { Airs } \\
\text { sérieux }\end{array}$} & 1 & $\begin{array}{l}\text { Rossignols vous chantez les douceurs du } \\
\text { printems, }\end{array}$ & 2 & $\mathrm{C}$ & $\begin{array}{l}\text { Treble, } \\
\text { flûte, } \\
\text { continuo }\end{array}$ & Da capo \\
\hline & 6 & Mes yeux ne versez plus de pleurs & 3 & $\mathrm{e}$ & Continuo & Ternary \\
\hline & 8 & Echos indiscrets, taisez vous, & $2 *$ & $\mathrm{~g}$ & Continuo & Binary \\
\hline & 10 & Funeste ennemy de la paix & 3 & $\mathrm{~A}$ & Continuo & Binary \\
\hline & 12 & Ruisseaux, suspendez vôtre cours & 2 & $\mathrm{a}$ & Continuo & Binary \\
\hline & 15 & Charmant repos paisible indifférence, & 3 & $\mathrm{D}$ & Continuo & Rondeau \\
\hline & 18 & $\begin{array}{l}\text { Mon cher troupeau sortons de ce } \\
\text { boccage, }\end{array}$ & 3 & $\mathrm{G}$ & Continuo & $\begin{array}{l}\text { Extended } \\
\text { Binary }\end{array}$ \\
\hline & 20 & $\begin{array}{l}\text { Que Tircis est charmant et qu'il est } \\
\text { amoureux }\end{array}$ & $3 *$ & $\mathrm{D}$ & Continuo & $\begin{array}{l}\text { Extended } \\
\text { Binary }\end{array}$ \\
\hline & 23 & $\begin{array}{l}\text { Apres m'avoir formé les plus aimables } \\
\text { chaînes, }\end{array}$ & 3 & $\mathrm{~d}$ & Continuo & Binary \\
\hline & 24 & Sombres lieux obscures forrets, & 3 & $\mathrm{a}$ & Continuo & Binary \\
\hline & 34 & La paix qui regne en nos aziles & 2 & $\mathrm{D}$ & Continuo & Binary \\
\hline & 36 & Douce innocence régne sur nos coeurs & 3 & $\mathrm{~d}$ & Continuo & Binary \\
\hline & 38 & Tendres amans qu'amour engage & 3 & $\mathrm{~A}$ & Continuo & Binary \\
\hline & 42 & Boccages frais aimable Solitude & 3 & A & $\begin{array}{l}\text { Treble } \\
\text { duo }\end{array}$ & Binary \\
\hline & 49 & Pourquoy le berger qui m'engage, & 3 & $\mathrm{a}$ & $\begin{array}{l}\text { Treble } \\
\text { duo }\end{array}$ & Binary \\
\hline & 67 & De richésses amy je ne suis point jaloux, & 3 & $\mathrm{C}$ & Continuo & Binary \\
\hline \multirow[t]{13}{*}{$\begin{array}{l}\text { Airs à } \\
\text { boire }\end{array}$} & 11 & Amans constans vous pouvez boire & 3 & $\mathrm{C}$ & Continuo & Binary \\
\hline & 14 & De la philosophie & $3 *$ & $\mathrm{G}$ & $\begin{array}{l}\text { Récit de } \\
\text { Basse } \\
\text { Taille }\end{array}$ & $\begin{array}{l}\text { Asymmetrical } \\
\text { Binary }\end{array}$ \\
\hline & 19 & Lors que l'on boit à mes amours & 3 & $\mathrm{G}$ & Continuo & Binary \\
\hline & 21 & $\begin{array}{l}\text { Buvons Lucas mais buvons tant luy } \\
\text { disoit Grégoire en pintant }\end{array}$ & 3 & $\mathrm{~F}$ & Vocal duo & $\begin{array}{l}\text { Asymmetrical } \\
\text { Binary }\end{array}$ \\
\hline & 39 & $\begin{array}{l}\text { Amans qui languissez sous de pesantes } \\
\text { chaînes }\end{array}$ & $3 *$ & $\mathrm{c}$ & $\begin{array}{l}\text { Récit de } \\
\text { Basse }\end{array}$ & $\begin{array}{l}\text { Asymmetrical } \\
\text { Binary }\end{array}$ \\
\hline & 41 & Buvons tous à la ronde & 98 & $\mathrm{C}$ & $\begin{array}{l}\text { Treble } \\
\text { monody }\end{array}$ & Binary \\
\hline & 46 & Célimeine à changé, & $\begin{array}{l}\text { Cut C } \\
*\end{array}$ & $\mathrm{~d}$ & Basse duo & $\begin{array}{l}\text { Asymmetrical } \\
\text { Binary }\end{array}$ \\
\hline & 52 & $\begin{array}{l}\text { Trop longtems à Bacchus j'ay disputé la } \\
\text { gloire }\end{array}$ & $3 *$ & $\mathrm{G}$ & Vocal duo & $\begin{array}{l}\text { Asymmetrical } \\
\text { Binary }\end{array}$ \\
\hline & 66 & Que les mortels sont misérables & $2 *$ & $\mathrm{C}$ & $\begin{array}{l}\text { Récit de } \\
\text { Basse }\end{array}$ & $\begin{array}{l}\text { Asymmetrical } \\
\text { Binary }\end{array}$ \\
\hline & 69 & $\begin{array}{l}\text { Pour guerir sans retour la plus vive } \\
\text { bléssure }\end{array}$ & $\mathrm{C} *$ & $\mathrm{C}$ & $\begin{array}{l}\text { Récit de } \\
\text { Basse }\end{array}$ & $\begin{array}{l}\text { Asymmetrical } \\
\text { Binary }\end{array}$ \\
\hline & 70 & $\begin{array}{l}\text { Dieu du vin quelle est donc ta fatalle } \\
\text { puissance, }\end{array}$ & $\mathrm{C} *$ & $\mathrm{e}$ & Continuo & $\begin{array}{l}\text { Asymmetrical } \\
\text { Binary }\end{array}$ \\
\hline & 72 & $\begin{array}{l}\text { Ah que l'homme est sçavant disoit un } \\
\text { jour Grégoire, }\end{array}$ & $2 *$ & $\mathrm{~d}$ & $\begin{array}{l}\text { Récit de } \\
\text { Basse }\end{array}$ & $\begin{array}{l}\text { Asymmetrical } \\
\text { Binary }\end{array}$ \\
\hline & 73 & L'autre jour pres d'un bosquet & 2 & $\mathrm{a}$ & Continuo & Binary \\
\hline
\end{tabular}

$*=$ these airs have multiple time signature changes. For an overview of the time signature changes in each air, see the catalogue of this collection which can be found in the appendix. 


\section{AIRS SERIEUX}

The majority of Pinel's airs sérieux are continuo-accompanied solo songs which were the best musical medium for their texts, that are serious and personal in character. ${ }^{2}$ This genre was beginning to decline by the time Pinel was writing, with the Ballard anthology series having come to an end in $1730 .^{3}$ Yet Pinel's airs in this form still make up the biggest group in her collection. Perhaps in compensation, the influence of the air à boire can be observed in some of these airs in which the solo voice is somewhat overshadowed by a more active bass line. ${ }^{4}$ However, it must be kept in mind that the air à boire was also in decline: a reaction to the favoured new genre, the cantatille.

The first air in Pinel's collection, 'Printems' ('Rossignols vous chantez') ${ }^{5}$, an air sérieux avec accompagnement de Flûtes, is one of only two airs written in da capo form, and includes a treble instrument in addition to the voice. ${ }^{6}$ The music specifies that the instrumental part is for a flute, however, it also indicates that more than one flute could play this part. The flute part, which precedes the voice, displays Italian influence. This is first seen in the use of a motto opening whereby the first phrase of the vocal part is interrupted by the accompaniment before being sung in its entirety. The voice partially imitates the instrumental opening and follows the same melodic contour. Throughout the air, the flute part displays characteristics exhibited in concertante airs of contemporary cantatas. ${ }^{7}$ In the sections where the voice and flute play together, the flute serves as a harmonising part to the voice and only displays virtuosity when it is on its own, with many runs and flourishes which include ornamentation in the form of trills

\footnotetext{
${ }^{2}$ Eastwood, 1984, p.91.

${ }^{3}$ Christophe Ballard issued his Recueils d'airs sérieux et à boire series until 1715, after which time his son Jean-Baptiste Ballard continued in this role until 1730. These monthly Recueils presented various air-types by a wide range of composers. Garden, 2005, pp.355-372.

${ }^{4}$ These airs include 'Funeste ennemy de la paix' (Catalogue no. 4. Volume II, p.10), 'Ruisseaux suspendez' (Catalogue no. 6. Volume II, p.12), 'Les charmes de l'indiférence' (Catalogue no. 8. Volume II, p.15), and 'De richésses amy' (Catalogue no. 27. Volume II, p.68).

5 The first words of this air are stated in brackets to avoid confusion with the cantatille, 'Le Printems' (Catalogue no. 25. Volume II, p.55), which draws comparisons to the current air sérieux, 'Printems' (Catalogue no. 1. Volume II, p.1).

${ }^{6}$ The other is the final air in the cantatille 'Le Printems' which is also in da capo form and has a part for a treble instrument. This work is discussed later and comparisons between the two airs are examined.

${ }^{7}$ Sadie cites this air in the chapter 'Musiciennes of the Ancien Régime'. Sadie, 1986, pp.209 \& 211.
} 
and grace notes. When viewed in relation to the text, the flute begins to take on qualities of the birds that the voice sings of:

Chantez, les douceurs du printems,

Heureux oiseaux, l'amour qui vous anime

Par vos aimables sons s'exprime,

Et les rend encor plus charmans. ${ }^{8}$

\section{Example 1, Pinel, 'Printems', bb.64-65.}

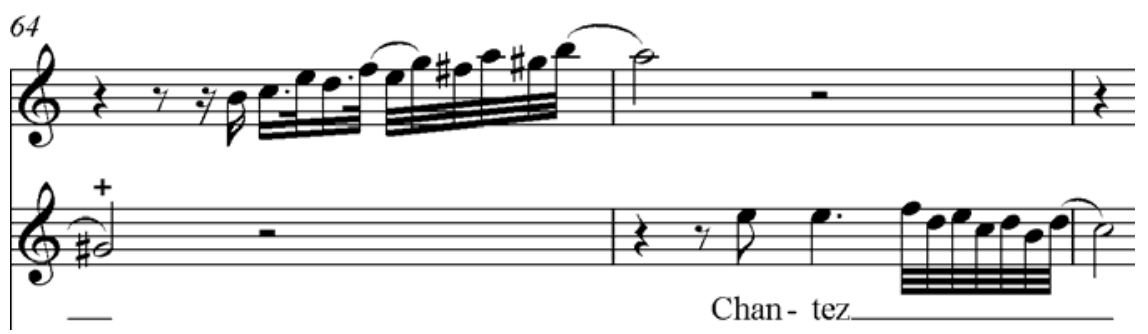

Certainly, in bars 63 to 78, the voice and flute have an exchange in which the flute is responding to the poet's instruction for the birds to 'sing again'. Moreover, the title's indication that the air is scored for flutes further suggests that the instrumental part is representative of the rossignols (nightingales).

The second air, 'Mes yeux, ne versez plus de pleurs', is in simple ternary form (ABA). ${ }^{9}$ The A section opens and closes in tonic key of E minor, supporting the lamenting quality of verses one and three: 'Mes yeux, ne versez plus de pleurs; /Tircis vient calmer mes allarmes' ${ }^{10}$ Furthermore, the basso continuo line is very much in a supporting role, allowing the vocal part to dominate with its lilting melody, until word painting occurs on three successive statements of 'brillez' (shine), which are set to quick melismas, each different to the statement preceding it. The modulation to $\mathrm{G}$ major in bars 22 to 23 corresponds to the poet's more positive outlook in the middle verse: 'Mais quand l'amour veut nous le rendre/Qu'il est doux de revoir ce qui nous a charmé'. ${ }^{11}$ This is also the only air in Pinel's collection in which the vocal part is written in a treble clef rather

\footnotetext{
${ }^{8}$ Sing again of the sweetness of spring./Happy birds, Love animates you/And is expressed in every lovely sound you make,/And makes each note more charming. Pinel, 'Printems', (1737). Catalogue no. 1. Volume II, p.1.

${ }^{9}$ The B section in ternary form airs clearly contrasts to the A section and is usually harmonically closed (as is the case with 'Mes yeux ne versez plus de pleurs'). This differs to the da capo air whose harmony is not closed between each section. W. Dean Sutcliffe, 'Ternary Form', Grove Music Online ed. L. Macy (Accessed 16 April 2008), http:www.grovemusic.com.

${ }^{10}$ My eyes, do not shed any more tears;/Tircis is coming to calm my fears. Pinel, 'Mes yeux ne versez plus de pleurs', (1737). Catalogue no. 2. Volume II, p.6.

${ }^{11}$ But when love wants to return it to us /How sweet it is to see again what has charmed us. Pinel, 'Mes yeux ne versez plus', (1737). Catalogue no. 2. Volume II, p.6.
} 
than the soprano clef. ${ }^{12}$ The rest of Pinel's airs are in binary form, with each half repeated.

The two epigrammatic airs sérieux composed by Pinel, 'Que Tircis est charmant' and 'Apres m'avoir formé les plus aimables chaines', are in extended binary form (ABB'), typical for texts which end with a moral or maxim, such as those found in Pinel's epigrammatic airs which are listed below: ${ }^{13}$
Ah, qu'il est dangereux
Quand on est tendrement aimée,
De sentir qu'un amant est digne d'être heureux. ${ }^{14}$
Ah si ses doux plaisirs font oublier ses peines,
Ses tourmens ne font pas oublier ses plaisirs. ${ }^{15}$

The two airs are very similar, both simple airs in triple time and marked 'Tendrement'. Although they are in different keys, they follow a similar modulation pattern, which can bee seen in the chart below:

Figure 10 Comparison of harmony in two epigrammatic airs.

\begin{tabular}{|l|l|l|l|l|}
\hline & A & B & B' & End \\
\hline & b.1 & bb.7-8 & bb.16-17 & \\
\hline 'Que Tircis est charmant' & D major & A major & B minor & D major \\
\hline $\begin{array}{l}\text { 'Apres m'avoir formé les } \\
\text { plus aimables chaines' }\end{array}$ & D minor & A minor & F major & D minor \\
\hline
\end{tabular}

The harmony in each air is relatively simple, not straying far from the dominant or relative key of the tonic, allowing the text to govern these airs.

\footnotetext{
${ }^{12}$ An overview of the clef-types and vocal forces in Pinel's recueil can be found under 'Editorial and Performance issues' on p.ix in volume II of this study.

${ }^{13}$ The text accompanying an extended binary air is usually a quatrain, and the final two lines are repeated to different music, thus creating section B'. This is a form with Italian origins, which Lully first used in his tragédies en musique, and which became common in Ballard's publications of airs. James R. Anthony's research into this form has shown that the extended binary air was not employed by other seventeenth-century composers of airs (such as Sicard, Ballard and La Barre), but that it was present in Ballard's Airs sérieux et à boire in the years following Lully's death. Jean-Baptiste de Bousset followed this Lullian tradition by composing in the form of the extended binary air, and he transformed the texture in his airs by juxtaposing counterpoint and rhythmic unison, and was also one of the early French composers to employ Italian characteristics such as motto openings and virtuoso passages. James R. Anthony, 'Lully's airs French or Italian?', Musical Times, Vol. 128, no. 1729, 1987, pp.126-129. Garden, 2005, pp.355372.

${ }^{14} \mathrm{Ah}$, how dangerous it is/When one is tenderly loved,/To have the feeling that a lover is worthy of being happy. Pinel, 'Que Tircis est charmant', (1737). Catalogue no. 11. Volume II, p.20.

${ }^{15} \mathrm{Ah}$ if his sweet pleasures make one forget his sorrows/His torments do make one forget his pleasures. Pinel, ‘Apres m'avoir formé les plus aimables chaines', (1737). Catalogue no. 13. Volume II, p.23.
} 
In the previous chapter, there was a brief discussion about the shocking imagery found in some of Pinel's texts. One of these was the air sérieux, 'Funeste ennemy de la paix', written by an unknown poet, and while it is the most highflown text included in her collection, the music Pinel set to it is the complete opposite. Opening in A major, the melody and harmony of this binary air is surprisingly cheerful in relation to the text: 'Perfide Amour, $\mathrm{Tu}$ ne te plais qu'à voir verser du sang, /A voir couler des larmes'. ${ }^{16}$ At section $\mathrm{B}$, there is a modulation to the dominant key, E major, and even though the music begins to hint at a minor key, which arrives in the form of B minor at bar 21, the extreme fury which pervades the text is not matched in Pinel's setting of the music. Perhaps this setting serves to counteract the text instead.

The music set to the middle verse of 'Printems', written by Pinel, is slightly more representative of the shocking imagery in it: 'Mon coeur hélas est aussy la victime/Du Dieu que célébrent vos chans./Mais pour moy ce seroit un crime... ${ }^{, 17}$ When this phrase begins at bar 45, the pace of the music becomes noticeably slower when the florid flute line slows to match the vocal line which is made up of predominantly minims and crotchets. A melodic descent on the first line mentioned above creates word painting, and on the final beat of bar 48 , the flute creates an augmented fifth with the voice, which is quickly resolved and followed by a cadence into A minor. A series of 7-6 suspensions correspond with the poet's attempt to refrain from 'giv[ing] expression to the fires of passion [he/she is] feeling, ${ }^{18}$

'Les charmes de l'indifférence' is a rondeau ${ }^{19}$ which draws on the musical language of composers such as Jean Baptiste de Bousset and exhibits the influence of Italian traits, most obvious in the harmonic language. Beginning in

\footnotetext{
${ }^{16}$ Treacherous Cupid,/You take delight only in seeing blood shed,/And in seeing tears flow. Pinel, 'Funeste ennemy de la paix', (1737). Catalogue no. 4. Volume II, p.10.

${ }^{17}$ My heart, alas, has also fallen victim/Of that God whom you celebrate in song/For me it would be a crime... Pinel, 'Printems', (1737). Catalogue no. 1. Volume II, p.1.

${ }^{18}$ De laisser éclatter les feux que je ressens. Pinel, 'Printems', (1737). Catalogue no. 1. Volume II, p.1.

${ }^{19}$ Rondeau (rondo) airs have a number of sections, the first of which returns between each new section (ABACA...). This form was popular in seventeenth- and eighteenth-century France. Malcom S. Cole, 'Rondo $>$ The rondeau in France in the 17th and early 18th centuries', Grove Music Online ed. L. Macy (Accessed 17 April 2008), http://www.grovemusic.com.
} 
D major, a chromatically ascending line reflects the adoration for nature which is expressed by the singer in the text, 'Vos plaisirs font tout mon bonheur'. ${ }^{20}$ At the same time, this melodic sequence unsettles the key in bars 8 to 10 and there is a shift towards the dominant minor key, A minor. The modulation into A minor in bars 15 to 16 is abruptly interrupted with a return to the opening music and text in bar 17 which picks up the tonic key of D major. The harmony mirrors this text, which highlights that when one has nature as the object of love, one can avoid getting hurt, just as an unsettling minor key can be evaded: 'Et jamais sous votre puissance,/L'on n'entend soupirer un coeur'. ${ }^{21}$ Section B begins in bar 25 and the harmony modulates to the dominant key, A major in bar 38 before moving towards a cadence into B minor in bars 48 to 49 , which fittingly coincides with the following text, 'D'un amant leger l'inconstance/Ne fera point couler mes pleurs'. ${ }^{22}$ Section A returns at bar 50, and there is a tierce de picardie cadence into D major in bars 65 to 66 . The harmony subsequently moves through $\mathrm{E}$ minor and $\mathrm{G}$ major before returning to the tonic key of $\mathrm{D}$ major. The amount of key change in comparison with most of the other airs in Pinel's collection is significant.

'Ruisseaux suspendez vôtre cours' is an air displaying well-defined Italian traits. Beginning in A minor, the walking bass line creates an unsettling harmonic structure with its chromatic and sequential movement. Coinciding with the second verse, the modulation to $\mathrm{E}$ minor in bars 12 to 13 does little to stabilise a key centre with an immediate move towards the unrelated key of D minor in bars 16 to 17 which is followed by another temporary modulation into $\mathrm{C}$ major in bars 21 to 22 , all of which reflects the very bitter and angry text, illustrated by the words in bold in the text below:

L'ingrat vient de trahir sa foy.

Je croy de ma douleur tout doit être l'image!

Qu'un silence effrayant regne dans ce boccage;

\footnotetext{
${ }^{20}$ Your pleasures are all my happiness. Pinel, 'Les charmes de l'indifférence', (1737). Catalogue no. 8. Volume II, p.15.

${ }^{21}$ And never under your power/Does a heart sigh. Pinel, 'Les charmes de l'indifférence', (1737). Catalogue no. 8. Volume II, p.15.

${ }^{22}$ The inconstancy of a light, fickle lover/Will not make me shed tears. Pinel, 'Les charmes de l'indifférence', (1737). Catalogue no. 8. Volume II, p.15.
} 
Que tout devienne aussy triste que moy! ${ }^{23}$

The fourth line of the extract above is set to a chromatically ascending continuo line beginning in bar 23, with a vocal line which moves upwards towards $d$ "' and is lingered on for three bars (bb.27 to 29), hinting at the key of D minor with a raised sixth. The earlier occurrence of $\mathrm{D}$ minor was also set to a self-referencing line in the poem, suggesting that the poet is linked to this key. The overall uncertainty of the key in this air simply contributes to the text which is lamenting a lost love, and perhaps alludes to the inconstancy of love which is a theme pervading the texts in this collection.

Contrastingly, we find harmonic language akin to the simplicity of Lambert in many of Pinel's airs sérieux, such as 'Mon cher troupeau sortons', in which there is no chromatic movement in the vocal line, and the modulations are definitive, governed by a tonic-dominant tension.

'Echos indiscrets, taisez vous' also adheres to the sweet, poignant tradition of Lambert by way of its melodic, song-like vocal line. Furthermore, the rhythm is generated from the language of the text, shown by the various time signature changes. However, there are examples of Italian influences in its harmony. Beginning in $\mathrm{G}$ minor, there is chromatic colouration with the raised third in the vocal line and figuring in bar 8 which resolves before modulating to the relative major key, B flat major. In the second half of the air, the vocal line begins its ascent upwards by an octave between bars 13 and 19, highlighting the poet's blissful state: 'Si Venus connoissoit l'objet de mon amour/Elle abandonneroit le céleste séjour'. ${ }^{24}$ Bars 16 to 17 are strikingly similar to bars 7 to 8 with their chromatic inflection which once again unsettles the harmonic structure. In both cases, these chromaticisms correspond to references to Gods in the text:

\footnotetext{
${ }^{23}$ The ingrate has betrayed his oath./To my mind everything must reflect my pain!/May a terrible silence reign in this grove;/May everything become as sad as me! Pinel, 'Ruisseaux suspendez vôtre cours', (1737). Catalogue no. 6. Volume II, p.12.

${ }^{24}$ If Venus knew the object of my love/She would abandon her celestial abode. Pinel, 'Echos indiscrets, taisez vous', (1737). Catalogue no. 3. Volume II, p.8.
} 
Example 2, Pinel, 'Echos indiscrets, taisez vous', bb. 7-8.

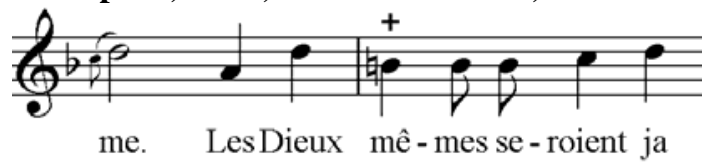

Example 3, Pinel, 'Echos indiscrets, taisez vous’, bb. 16-17.

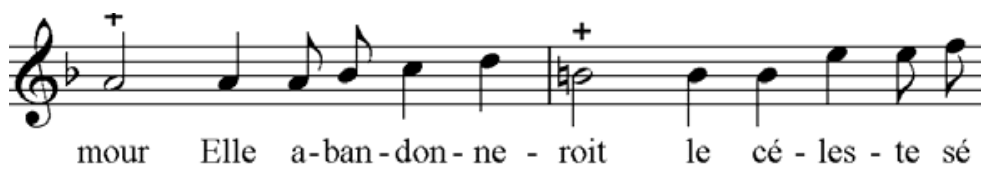

The modulation to $\mathrm{D}$ minor in bars 23 to 24 proves to be temporary due to an ascending chromatic bass line which follows, resting on a diminished seventh chord on 'feu' (flame) in bar 26.

The word painting employed by Pinel is standard for many eighteenth-century composers who set music to text. As a rule, she sets nouns and verbs of motion and action such as 'couler' (to flow) and 'chanter' (to sing) to long melismas or ornamental flourishes, an example of which can be observed below:

Example 4, Pinel, 'Funeste ennemy de la paix', bb.10-11.

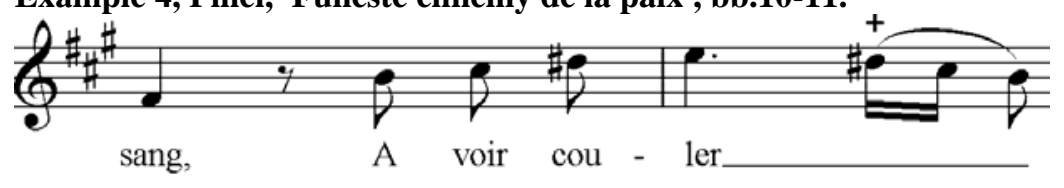

Words such as 'chaisne' [chaîne] (chain) were often to set a melisma, to symbolise unity and the binding nature of a chain:

Example 5, Pinel, ‘Apres m’avoir formé’, bb.3-4.

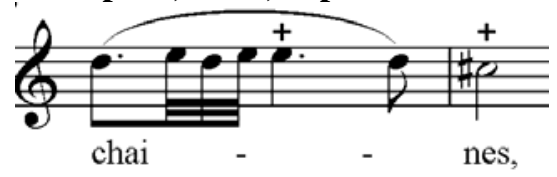

The term 'chaine' appears in many airs, and in most cases it is set to an ornamentation or melisma.

In phrases referring to happiness, melodies are often set to ascending melodic lines, whereas the opposite is found with descending melodic lines, which are set 
to unhappy phrases and terms. Furthermore, ornamental devices, such as trills and grace notes, are usually set to words like 'soupir' (sigh) and 'amour' (love):

\section{Example 6, Pinel, 'Les charmes de l'indifférence’, bb.14-15.}

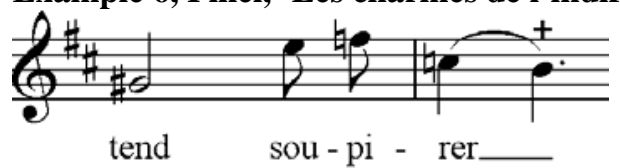

Example 7, Pinel, 'Printems', bb.32-33.

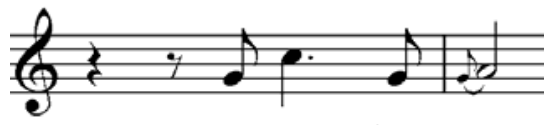

Le ten - dre a-mour

\section{Musettes}

Pinel's collection includes two musettes, a type of air defined by Meredith Ellis Little as a 'dance-like piece of pastoral character whose style is suggestive of the sound of the musette or bagpipe'. ${ }^{25}$ The theme pervading both airs is a desire and yearning for simplicity, which is reflected in the musical setting of the words. The melodic lines are placed above a figured drone which imitates the air's namesake, the musette, a small type of bagpipe that was popular in seventeenthand early eighteenth-century France. ${ }^{26}$ It was typical for the bass part in musettes to be a drone, usually on the tonic, and the upper voice or voices held the melody. ${ }^{27}$ Similar musical settings also appear in compositions by Pinel's contemporary, René Drouard de Bousset. ${ }^{28}$ What is unusual about Pinel's musettes is the syncopated setting of the drone:

\footnotetext{
${ }^{25}$ Meredith Ellis Little, 'Musette', Grove Music Online ed. L. Macy (Accessed 12 March 2008), http://www.grovemusic.com.

${ }^{26}$ Robert A. Green, 'Musette', Grove Music Online ed. L. Macy (Accessed 12 March 2008), http://www.grovemusic.com.

${ }^{27}$ Little, 'Musette', http://www.grovemusic.com.

${ }^{28}$ René Drouard de Bousset (1703-1760) was the son of Jean-Baptiste de Bousset, and was a composer and organist. David Tunley, Catherine Cessac, 'Bousset, René Drouard de', Grove Music Online ed. L. Macy (Accessed 2 February 2008), http:www.grovemusic.com. His airs of this nature can be found in two volumes of his Nouveau Airs nouveaux sérieux et à boire (1731), his cantata En form dialogue (1740) and in the instrumentation for his Concertos en trio (1736). Felicity Smith, 'René Drouard de Bousset', MMus thesis, Victoria University of Wellington, 2008.
} 
Example 8, Pinel, 'Musette pour un berger', bb.1-2.

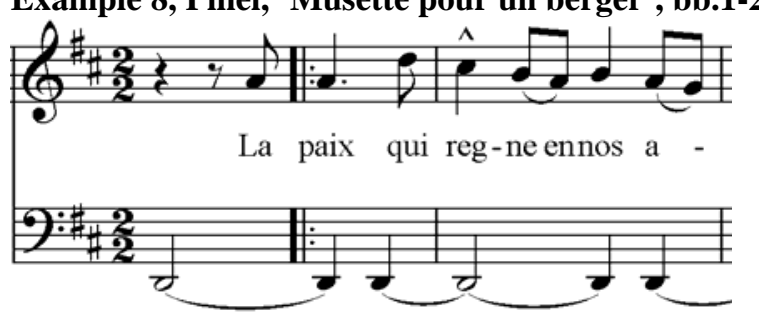

The first musette, in D major and duple metre, employs various instances of word painting which enhance the simple air. For example, 'La pompe des Rois' (the pomp of Kings) in bars 7 to 8 is accompanied by a sudden jump of a major sixth in the vocal line and by an octave in the figured bass line, symbolic of the grandeur and pomp referred to in the poem: 'Nous fuyons le bruit des villes, La pompe des Rois nous fait peur'. ${ }^{29}$ Contrastingly, the simple way of life is expressed in a harmonic example of word painting in bar 14 where the $\mathrm{C}$ sharp is suppressed on the word 'simplicité'.

The title 'Parodie' is given to the second verse of the first musette, and this is a technical term meaning new words are fitted to existing music. The only differences between the two verses can be observed in some of the flourishes in the vocal line, and in the figuring of the basse continue part which provides some different harmonic colouring. An instance of word painting appears in the sixth bar on the word 'parer' (to adorn) in verse one, in which the descending melodic line is adorned by a semi-quaver and dotted quaver combination:

\section{Example 9, Pinel, 'Parodie du premier', b.6.}

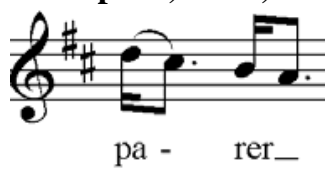

'Musette pour une bergere' differs from the first musette by being in triple meter, and it has the key signature of D minor. It may be that Pinel chose the opposite time signature and mode to reflect the change to a female poetic voice with the 'bergere' as opposed to the 'berger' of the first musette. The shepherds seem to be symbolised by major tonalities which is made clear in this air when the music

\footnotetext{
${ }^{29}$ We escape the noise of cities,/The pomp of Kings frightens us. Pinel, 'Musette pour un berger', (1737). Catalogue no. 16. Volume II, p.34.
} 
modulates to the key of F major in bars 28 to 29 when the shepherdess sings of 'Nos bergers' (our shepherds), thus connecting this air with the previous two musettes. Once again, we find that the music imitates the dichotomy of simplicity and grandeur that is the subject of these texts, by way of the figured bass line which begins with the same simple drone, albeit one octave higher. This is interrupted by a descending line which gathers momentum in bars 7 to 8 , and which coincides with the word 'seducteur'. The bass line reverts to the drone in bar 10. See figure 8 below.

Douce innocence

Régne sur nos coeurs

Chere ignorance

Des biens séducteurs.

Ta jouissance

Conserve nos moeurs,

Et l'espérance

Des vaines grandeurs

N'a point de puissance,

Où l'on s'en tes faveurs: ${ }^{30}$

Example 10, Pinel, ‘Musette pour une bergere', bb.5-9.

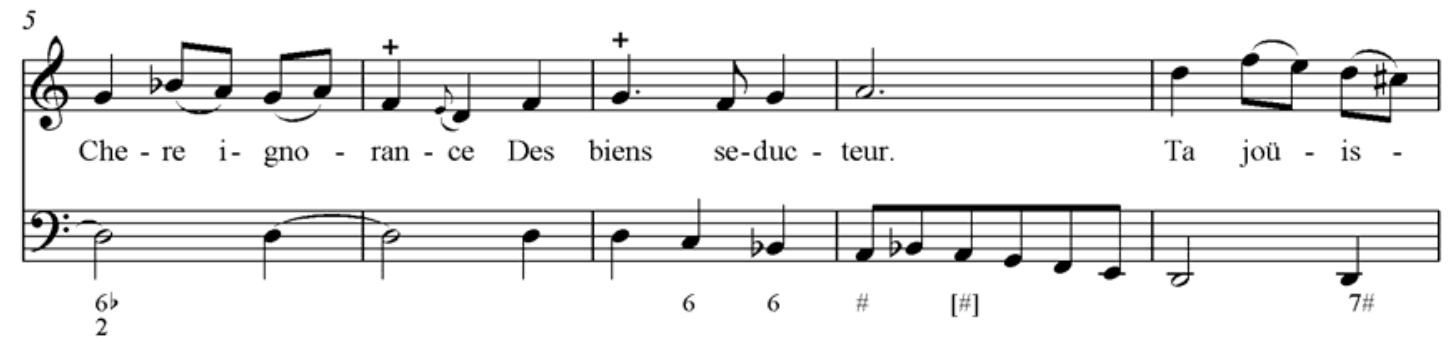

\section{Brunettes}

The brunette was another form of air, popular in the seventeenth and eighteenth centuries, described as inherently 'French' because of its simplicity and elegance. ${ }^{31}$ The first brunette in Pinel's collection, 'Mon cher troupeau sortons', is a very simple, short air comprising 21 bars. It is characteristically in binary form and modulates once to $\mathrm{C}$ major in section $\mathrm{B}$ before returning to the tonic key, G major. The simplicity of the music reflects the pastoral theme of the poem, and the same can the said for 'Boccages frais', a longer brunette made up of two strophes:

\footnotetext{
${ }^{30}$ Sweet innocence /Rules over our hearts/Dear ignorance/Of seductive things./Taking pleasure in you /Keeps our customs safe,/And longing /For empty grandeur /Has no power,/For one in your favour. Pinel, 'Musette pour une bergere', 1737. Catalogue no. 17. Volume II, p.37.

${ }^{31}$ David Tunley, 'Brunette', Grove Music Online ed. L. Macy (Accessed 24 March 2008), http://www.grovemusic.com.
} 
Boccages frais, aimable Solitude,

Qui d'un coeur amoureux charmez l'inquiétude,

Riches présens de Flore, ornemens de ces lieux

Que l'aurore embellit pour enchanter les yeux: ${ }^{32}$

The strophes are set to the same music with some small melodic and harmonic variations. This air is written in the relaxed, popular style of the seventeenth century. It is scored for two female voices, who sing in homophony throughout, mostly in thirds.

The third brunette, 'Pourquoy le berger qui m'engage' is composed in the poignant style of the seventeenth-century composer, Lambert. Like the previous brunette discussed, this air is also scored for two female voices who sing in homophony. Pinel wrote the text in three strophes, and each is set to the same music in binary form. The key is A minor, reflecting the sad, lamenting text: 'Pourquoy le berger qui m'engage,/Vient-il de ralentir ses feux' ${ }^{33}$ Each verse is more embellished than the first, which is suggestive of vocal doubles and can be observed in the musical examples below:

Example 11, Pinel, 'Pourquoy le berger qui m’engage’, strophe 1, bb. 14-15.

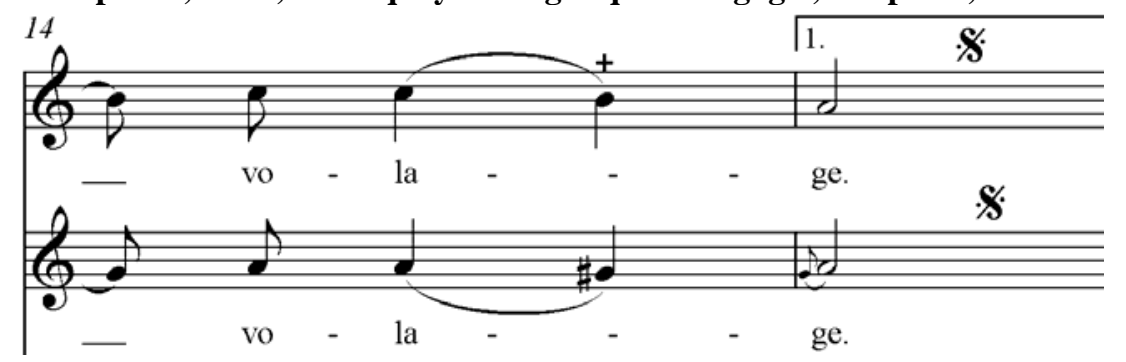

Example 12, Pinel, 'Pourquoy le berger qui m'engage', strophe 2, bb. 11-13.

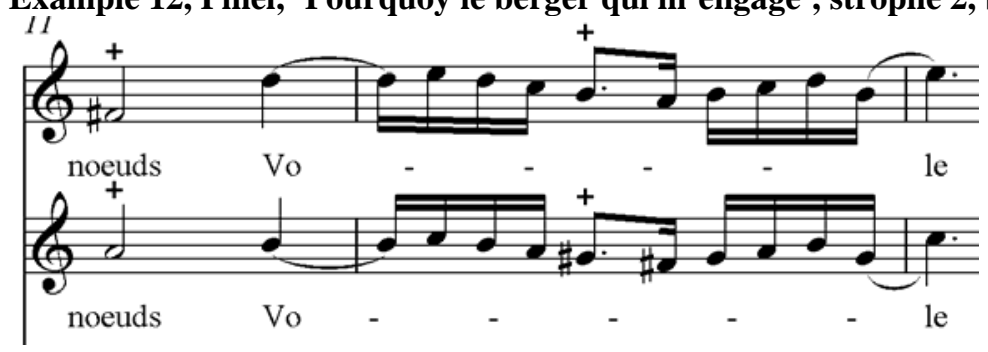

${ }^{32}$ Refreshing woods, sweet solitude,/Who charm my loving, anxious heart,/Rich abundance of flora, ornaments of these surroundings/That the dawn embellishes to enchant the eyes. Pinel, 'Boccages frais', (1737). Catalogue no. 21. Volume II, p.43.

${ }^{33}$ Why has the shepherd who is committed to me,/Just now let his passion wane. Pinel, 'Pourquoy le berger qui m'engage', (1737). Catalogue no. 23. Volume II, p.50. 
Example 13, Pinel, 'Pourquoy le berger qui m’engage', strophe 3, bb. 12-15.

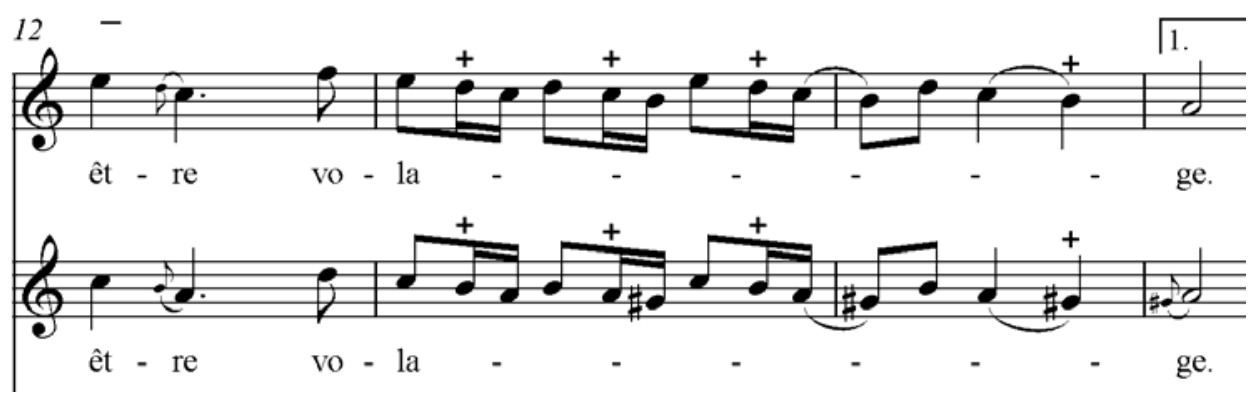

The French practice in the air de cour had been to add diminutions in the second and later verses, which served as variations on the initial melody. ${ }^{34}$ Later on, this practice was termed 'double' in airs sérieux and other airs. ${ }^{35}$

\section{THE WORK OF PINEL AND RENÉ DROUARD DE BOUSSET COMPARED}

The text 'Lors que 1'on boit à mes amours' was also set to music by René Drouard de Bousset eight years previously, ${ }^{36}$ and there are some similarities between the two airs à boire, the most obvious being that they are both binary form airs set in triple time. Pinel set this air in $\mathrm{G}$ major, reflecting the celebratory mood of the text. At the end of the first half, there is a modulation to the dominant minor key, D minor, with a tierce de picardie. In contrast, Bousset's air begins in $\mathrm{D}$ minor, portraying the text in a more sombre manner. Even though there is a modulation to the relative major key of $\mathrm{F}$ major at the end of the first half, the harmonic language of Bousset's figured bass line creates tension by moving away from F major quickly. In particular, the bass line in bars 11 to 14

\footnotetext{
${ }^{34}$ Greer Garden, 'Improvisation', Grove Music Online ed. L. Macy (Accessed 24 March 2008), http://www.grovemusic.com.

${ }^{35}$ Lambert was one of the first composers to transcribe ornamentation and he printed many doubles in his music. In fact, the question has been posed as to whether Lambert in fact composed the ornamentation for some of Lully's music because it is said that Lully disliked the practice of doubles in music: '[Lully's] instrumentalists did not take it upon themselves to ornament their parts. He would not have allowed them to do this any more than he allowed it with his singers. He did not think it was right when they imagined they knew more than he did and added graces to their parts. When this happened, he grew angry and quickly set them straight. More than once in his life he broke a violin across the back of a musician who was not playing it the way he wanted.' Mentioned by Sénecé, (H1688, p.299), Montéclair (H1736, pp.86-7) and Le Cerf de la Viéville (H1705, p.227), cited by Kah-Ming $\mathrm{Ng}$, 'Ornaments $>$ French Baroque $>$ Historical Overview', Grove Music Online ed. L. Macy (Accessed 16 April 2008), http://www.grovemusic.com.

${ }^{36}$ This piece can be found in Appendix 4. René Drouard de Bousset, Recueil d'airs nouveaus sérieux et à boire I (Paris: Boivin, Le Clerc, 1731), p.29.
} 
ascends a major fifth chromatically before descending again to rest on $\mathrm{C}$ sharp in bar 14: 'Que je passerois d'heureux jours/Si l'on buvoit à moy Silvie'. 37

Example 14, Bousset, 'Lors que l'on boit à mes amours', bb.11-15.

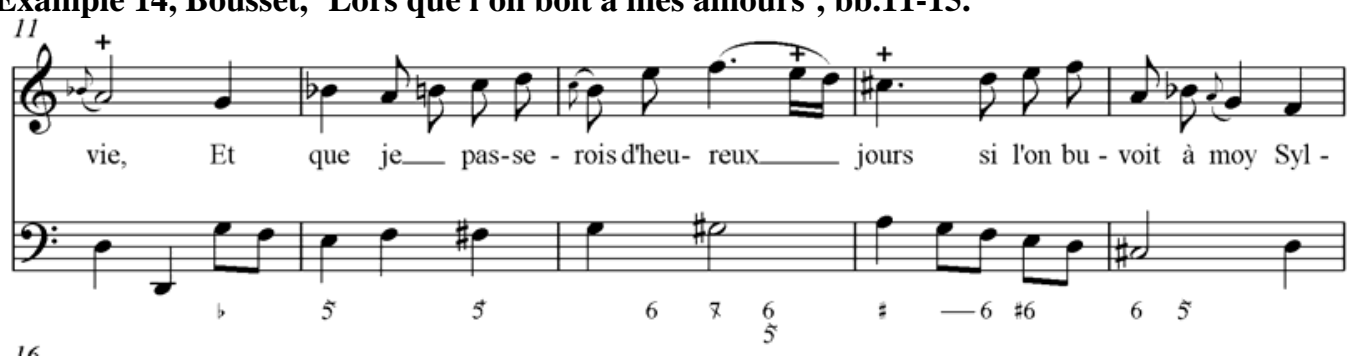

While Bousset's setting of this text is more colourful harmonically, which comes through in the figured bass part, Pinel's setting of the text has a greater focus on the vocal line:

Example 15, Pinel, 'Lors que l'on boit à mes amours', bb.9-14.

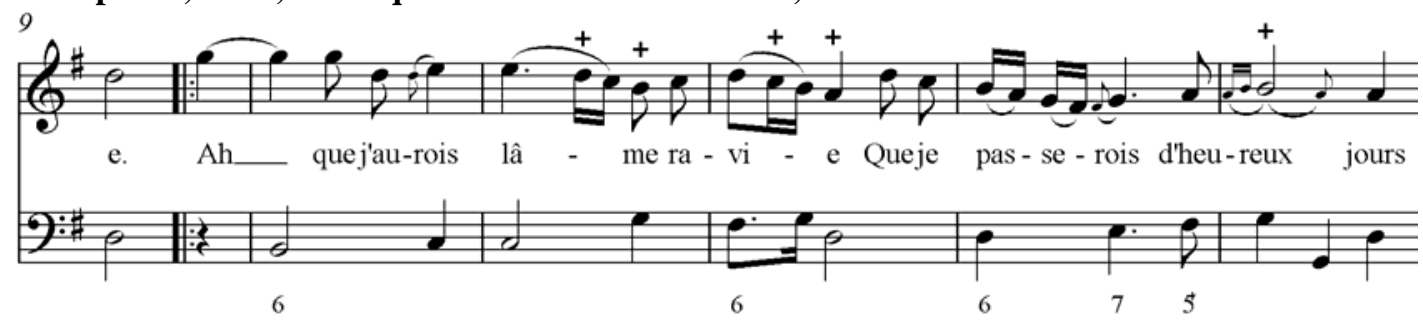

It is more ornamental with word painting. For example, every reference to the vocalist's object of love, Silvie, is adorned with some sort of flourish, chromaticism or grace:

Example 16, Pinel, 'Lors que l'on boit à mes amours', bb. 1-3.

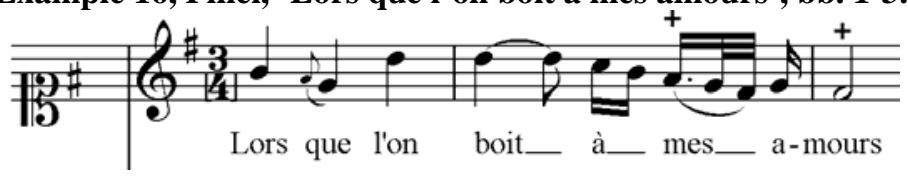

Pinel's figured bass line is more active in the second half of the air, and ascends in a stepwise fashion in bars 13 to 14 , which is the same section where Bousset's bass is ascending chromatically in his air. The text at this point reads 'Que je passerois d'heureux jours ${ }^{, 38}$ and the ascending bass lines may both be reflecting the idea of passing through life from day to day. Whether or not Pinel was aware

\footnotetext{
${ }^{37}$ How I would spend happy days/If they were raising a glass to me, Silvie. Bousset, 'Lors que l'on boit à mes amours', (1731). Catalogue no. 10. Volume II, p.19.

${ }^{38}$ How I would spend happy days. Pinel, 'Lors que l'on boit à mes amours', (1737). Catalogue no. 10. Volume II, p.19.
} 
of Bousset's setting of this text is uncertain, particularly because the similarities between the two airs are typical of many airs in this genre.

\section{AIRS À BOIRE}

\section{Récits}

According to Eastwood, récits de basse marked an important development away from the traditional French concentration on high vocal ranges. ${ }^{39}$ Five of the airs in Pinel's collection are récits de basse (four are for Basse and the fifth is for Basse Taille; for each only a vocal line is present) thus making up a small yet significant part of Pinel's recueil. All of the examples in this genre are characteristic drinking songs, and the vocal parts adhere to the style of French recitative, being very melodic, rather than to the Italianate speech-like style. The question is raised as to whether such pieces were performed as they were written, or whether a continuo or other vocal line was added for interest and to provide support. ${ }^{40}$ There is no basse continue part or figuring included in any of Pinel's récits, however, some composers did include basse continue parts in their récits ${ }^{41}$ which were usually a simplified version of the vocal line.

Pinel's récits all have regular time signature changes and expressive markings which help to generate the dramatic style of these airs. All five are made up of two sections; given that the second half in each is substantially longer than the first, their form can be classified as asymmetrical binary.

The first récit in Pinel's Nouveau recueil, 'De la philosophie', is treated motivically with a descending melodic phrase which expands on each occurrence, mirroring the way the poem gradually reveals its purpose over the course of each line: 'De la philosophie/J'ay formé je le pense un Sisthéme certain'. ${ }^{42}$ For lines one and two, the phrase spans a minor sixth (bars1 to 4 ), at lines three and four it spans a major sixth (bars 4 to 10), at line five it descends a

\footnotetext{
${ }^{39}$ Eastwood, 1984, p.89.

${ }^{40}$ Eastwood, 1984, p.89.

${ }^{41}$ In earlier Ballard volumes, these can be found: for example, 'Amis puis qu'un paix profonde', in Ballard's Recueil d'airs...pour l'année 1699, p.152 cited in Eastwood, 1984, p. 97.

42 About philosophy/I have formed thoughts, I think, a sure theory. Pinel, 'De la philosohpie', (1737). Catalogue no. 7. Volume II, p.14.
} 
major seventh (bars 11 to 15), and at line six, 'Le vin sçait me donner un courage invincible', ${ }^{43}$ it reaches down an octave (bars 16 to 22 ) just as the poet gathers the 'courage' to 'suivre l'amour' (follow Cupid). Lines seven and eight (bars 23 to 32) maintain this descending melody, however, it is not fully resolved and an imitative passage from bar 33 until the end repeats the final two lines with embellishments, including a long melisma on 'lance' (throw).

The practice of repeating the final lines of the texts numerous times, to bring out the point of the verse, occurs in each of Pinel's récits de basse. 'Pour guérir sans retour la plus vive bléssure' reiterates the final couplet for over half the air from bars 24 to 58 , each time being melodically different: 'Oh l'aimable contre poison,/Vidons encore cette pinte' ${ }^{44}$ On each repetition of this couplet, the action of emptying another pint is represented. Likewise, 'Ah que l'homme est sçavant' repeats the final line, 'je sçais soufler de bon vin', ${ }^{45}$ a total of six times from bars 35 to 48 . With each setting of the word 'soufler', ${ }^{46}$ the music changes, and bars 44 to 46 are the most elaborate of all, the words having been set to a long melisma. It seems to be that with each occurrence, the music is trying to become something different, symbolising the futile activities of alchemists, which is the rationale behind this poem. However, the final statement of this line ends just as it began, and like alchemy is projected in this text, the music is unable to transform itself:

Example 17, Pinel, ‘Ah que l'homme est sçavant', bb. 35-36.

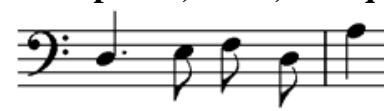

Mais jesçaissou-fler

Example 18, Pinel, 'Ah que l'homme est sçavant', bb. 47-48.

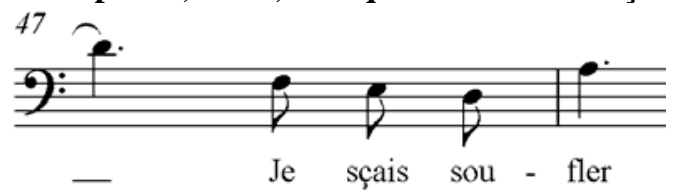

${ }^{43}$ Wine can give me an invincible courage. Pinel, 'De la philosohpie', (1737). Catalogue no. 7. Volume II, p.14.

${ }^{44}$ Oh, what a pleasant antidote it is,/Let us empty this pint once more. Pinel, 'Pour guérir sans retour', (1737). Catalogue no. 28. Volume II, p.70.

${ }^{45}$ I can make good wine disappear. Pinel, 'Ah que l'homme', (1737). Catalogue no. 30. Volume II, p.73.

${ }^{46}$ The meaning of this word is discussed in the chapter on Pinel's poetry. See Chapter 5, p. 55. 
As discussed in the previous chapter on Pinel's texts, 'Ah que l'homme est sçavant' has a unique topic, alchemy. The idea of beginning the alchemic process with base metals, or simple materials is reflected in the harmony of section A (bars 1 to 11) whose key is D natural minor, or Aeolian mode, given that there are no raised sixth or seventh notes. Word painting ensues in section $\mathrm{B}$, in which Pinel sets very static melodic phrases to the text 'Apres mille travaux l'on ne voit rien encor./L'on fixe le mercure on a beau me le dire, ${ }^{47}$ and the word 'l'or' (gold) is set to an $e^{\prime}$, the highest pitch in the air, as if the music is trying to reach something that it cannot reach, just as base metal cannot be turned into gold. The idea of something unattainable pervades this air: it is the least florid récit de basse in Pinel's collection, the quickest note value being a quaver. Furthermore, the harmonic language is simple, not straying far from the tonic key and there is an absence of chromatic movement.

\section{Duos à boire}

The duo created a style in which the music could match the text, allowing the two vocalists to converse in a style appropriate to the nature of most drinking songs, which celebrate the bottle in a humorous and light-mannered fashion. ${ }^{48}$

All of Pinel's drinking duos have similar structures: 'Buvons Lucas"49 and 'Trop longtems à Bacchus, ${ }^{50}$ are scored for soprano and bass voice, and 'Célimeine à changé ${ }^{51}$ is composed for two bass voices. As we find in Pinel's récits, they are all asymmetrical binary airs and Pinel repeats the final line or lines of text numerous times for emphasis. Unlike the duos by Jean Sicard, none of Pinel's duos include a part for basse continue or other instrument, and they are not figured. ${ }^{52}$ Pinel's duos can function autonomously due to their constantly changing time signatures ${ }^{53}$ which affect the tempo and provide interest and

\footnotetext{
${ }^{47}$ After a thousand endeavours we still see nothing/Mercury is fixed in solid form, in vain do they tell me. Pinel, 'Ah que l'homme est sçavant', (1737). Catalogue no. 30. Volume II, p.73.

${ }^{48}$ Eastwood, 1984, p.91.

${ }^{49}$ Catalogue no. 12. Volume II, p.21.

${ }^{50}$ Catalogue no. 25. Volume II, p.52.

${ }^{51}$ Catalogue no. 22. Volume II, p.46.

${ }^{52}$ Some of Sicard's duos require the extra instrumental parts because they are dialogues. For example, in 'La vigne est en amour', the voices don't join forces until bar 28 at which time there are some imitative passages.

${ }^{53}$ See the notes on time signatures in the editorial method for more information.
} 
change within the small structure of the air, because the words are dramatised so closely. They are mostly homophonic in texture, but all have imitative and sequential passages as well.

'Buvons Lucas' fits Eastwood's description of this air type, in which a bold affirmation of the pleasures of wine prevails throughout the air. The last part of the air is an extension of the final lines which are repeated numerous times in sequence and imitation. ${ }^{54}$ 'Célimeine à changé' also repeats the final lines of the text many times, making up thirty-five bars worth of music, which is over half of the air: 'Si je perds la raison/Que ce soit à force de boire'.

\section{Fanfare and Vaudeville}

Pinel's collection includes one short air called a fanfare, 'Buvons tous a la ronde', whose three-strophe text celebrates love and wine:

Buvons tous à la ronde Qu'on nous verse toujours:

Puisse autant que le monde

Durer ce vin et nos amours! ${ }^{56}$

\section{Example 19, Pinel, 'Buvons tous a la ronde', bb.1-3.}

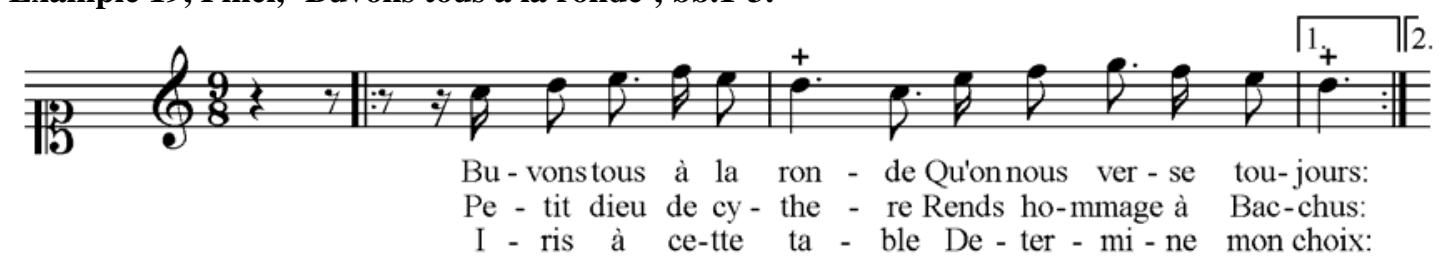

This is the only air set in a compound time signature $9 / 8$, and it is scored for soprano clef only. Many solo treble songs from this period were simply short, frivolous vaudeville melodies. ${ }^{57}$ The eighteenth-century French fanfare is not much different, usually short, quick, repetitive pieces of music with little musical value, and which perhaps resulted from the influence of the sound of hunting signals. ${ }^{58}$ As is the case with récits de basse, it is unclear whether these pieces

\footnotetext{
${ }^{54}$ Eastwood, 1984, p.91.

${ }^{55}$ If I lose my reason /May this come to pass through drinking. Pinel, 'Celimeine a changé', (1737). Catalogue no. 22. Volume II, p.47.

${ }^{56}$ Let us drink a round/That they always pour out for us/May this wine and our loves last/As long as the world! Pinel, 'Buvons tous a la ronde', (1737). Catalogue no. 20. Volume II, p.42.

${ }^{57}$ Eastwood, 1984, p.89.

58 Edward H. Tarr, 'Fanfare', Grove Music Online ed. L. Macy (Accessed 25 March 2008), http://www.grovemusic.com.
} 
were performed solo, as they are written, or whether performers added other parts.

The air closing Pinel's recueil is a vaudeville, 'L'autre jour pres d'un bosquet', conforms to some of the features typical of the genre, being short and folk-like. This is another short air, comprising fifteen bars. It is set in A minor which heightens the humorous, sly subject manner which is also expressed through the text: ${ }^{59}$ 'Le traitre d'un ris moqueur/Décoche un trait et s'envole' ${ }^{60}$ The vocal line and bass line move predominantly in contrary motion, however, the bass line is not figured and it is unclear whether this part is instrumental or vocal

\section{SCÈNE PASTORALE}

Pinel's foray into the operatic style is her dialogue, Scène Pastorale, in which a dramatic idiom has been embraced. The dialogue was by no means a new genre, having been composed for airs de cour from the early seventeenth century onwards.

The importance placed on conversation by society influenced music and the dialogue became the perfect medium for composers to create more exciting, dramatic pieces that expressed important sentiments with lively characters. Sicard was one such composer who experimented with theatrical word setting, using rests to break up phrases and using parody to enhance comic texts. ${ }^{61}$ Theatrical influence is evident for example in Sicard's dialogue for basse and two violins, 'Ne vous estone pas si mon creux est profound' which employs imitation, word-painting, and scale-like passages for the vocal part. ${ }^{62}$

Composed for dessus and haute-contre, Pinel's Scène Pastorale is constructed as a small dramatic scene made up of alternating recitatives and airs, with a concluding duo. The transitions between recitative and air in Pinel's Scène

\footnotetext{
${ }^{59}$ Clifford Barnes, 'Vaudeville', Grove Music Online ed. L. Macy (Accessed 25 March 2008), http://www.grovemusic.com.

${ }^{60}$ The traitor with a mocking laugh /Fires an arrow and flies off. Pinel, 'L'autre jour pres d'un bosquet', (1737). Catalogue no. 31. Volume II, p.74.

${ }^{61}$ Godtschalk, 1:65\&73.

${ }^{62}$ Godtschalk, 1:69.
} 
Pastorale flow smoothly, which was a hallmark of the French operatic style. The intensity of Iphis' expression of love for Daphne is reflected in the harmony of his opening recitative and air which begins in D minor and modulates four times within the space of thirty bars, creating drama from the outset and heightening his pledge of love. The first modulation to F major in bar 7 occurs when Iphis prepares to pledge his love to Daphné, 'Si c'est au plus constant que vous devez..., 63 and the move to $\mathrm{G}$ minor in bar 14 corresponds with his expression of love, 'Connoissez aujourd'huy/L'exces de mon amour' ${ }^{64}$ It is when Iphis sings about Daphné at bar 23, 'Non, vous qui sçavez tout charmer', ${ }^{65}$ that there is a further modulation to A minor, and it returns to D minor at bar 30 preceding Daphné's entrance.

Pinel employs word painting in bar 5 with a descent in the vocal and figured bass lines coinciding with 'ceder' (to surrender), and in bar 13 the voice is suspended on the verb 'attendre' (to wait). This technique continues throughout the Scène Pastorale with grace notes set to phrases whenever the lovers refer to one another, for example at the words 'mon homage' in bar 44, and 'enflammé' which is set at the top of an ascending melodic line in bar 77:

Example 20, Pinel, 'Scène Pastorale', bb. 43-44.

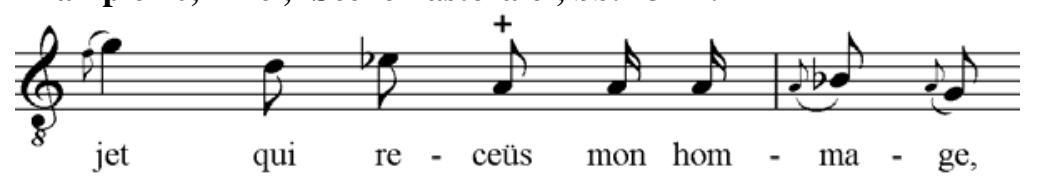

Example 21, Pinel, 'Scène Pastorale’, bb. 76-77.

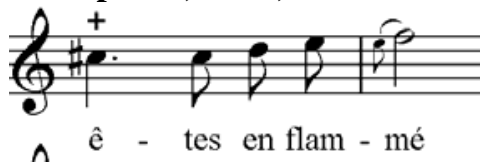

Iphis' final solo is much different in style. Until now, the metre has alternated between quadruple and triple time to match the prosody and to mark the changes in style and tempo, occurring in the following bars: b.7, b.37, b.42, b.46, and

${ }^{63}$ If it is to the most faithful that you would surrender... Pinel, Scène Pastorale, (1737). Catalogue no. 15. Volume II, p.26.

${ }^{64}$ Know today/The great extent of my love. Pinel, Scène Pastorale, (1737). Catalogue no. 15. Volume II, p.26.

${ }^{65}$ No, you who know how to charm everyone. Pinel, Scène Pastorale, (1737). Catalogue no. 15. Volume II, p.26. 
b.48. In bar 106 , the meter becomes $2 / 2$ for the first time and in conjunction with a modulation to $\mathrm{D}$ major, the style and character of this section changes completely.

J'en atteste ces lieux à Pâlés consacrez,

Ces bois de nos bergers en tous tems revérez, ${ }^{66}$

Adopting a dance-like quality, this section is akin to a gavotte, a popular French dance from the late sixteenth century which was often set to pastoral texts in the eighteenth century. ${ }^{67}$ As was typical in the gavotte, this section typically begins on the third beat of the bar and moves fairly quickly with a simple and regular rhythm: the music matches the text in which both characters have finally and conclusively expressed their love and fidelity to one another. In bar 114, the expressive marking 'Vivement' is given, and the pace of the music speeds up when Iphis' oath of love becomes increasingly ornate:

Puissent ces arbres verds dépouillez de verdure

Ne reprendre jamais leur aimable parure

Puissent ces lieux charmans être d'affreux déserts

Si jamais je brise mes fers. ${ }^{68}$

The bass line is more active between bars 114 and 117 whose melody compliments the haute-contre which moves a third above the bass line for most of these four bars. From bars 119 to 127, which mark the end of Iphis' solo, the figured bass is made up of mostly crotchet beats, providing finality and strength to the music and text.

\section{Example 22, Pinel, ‘Scène Pastorale’, bb.119-122.}

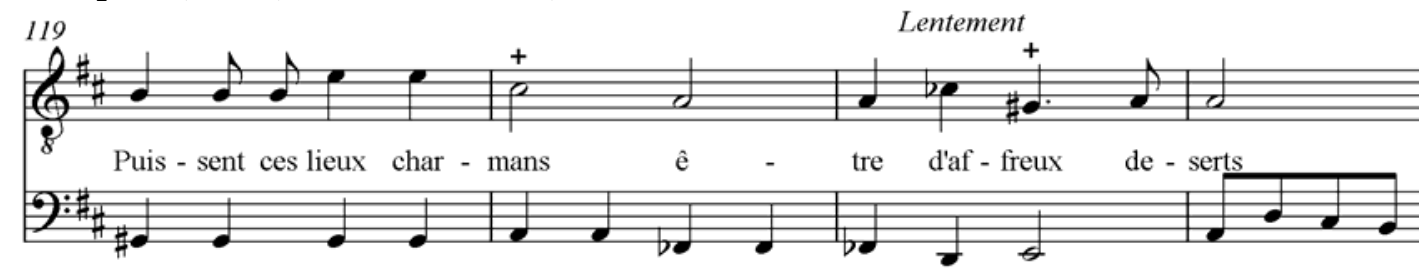

For the final duo, the music returns to triple meter and Iphis and Daphné sing in homophony for most of the air. The key of D major is retained, as if it is

\footnotetext{
${ }^{66}$ I swear to it by all that Pallas holds dear,/These woods [that] our shepherds forever revere. Pinel, Scène Pastorale, (1737). Catalogue no. 15. Volume II, p.26.

${ }^{67}$ Meredith Ellis Little, 'Gavotte', Grove Music Online ed. L. Macy (Accessed 16 April 2008), http://www.grovemusic.com .

${ }_{68}$ May these green trees be stripped of their leaves/Never to bring back their lovely finery/May these charming fields be hideous deserts/If I ever break my vows. Pinel, Scène Pastorale, (1737). Catalogue no. 15. Volume II, p.26.
} 
symbolic of their union, and the typical characteristics of word painting in love lyrics appear, with a long melisma on the word 'chaine'. There is a modulation to B minor, coinciding with the text's warning: 'Craignons l'éclat dans les plaisirs/Que nous prépare notre chaine'. ${ }^{69}$ In bar 37, the voice part and the hautecontre echoes the dessus until the end of the air which concludes on D major, the key symbolising their love and harmony. The concluding duo can be split into three sections: bars 1 to 16 , bars 17 to 32 , and bars 33 to 44 respectively. In the first section, the first two lines of text are repeated and on the repetition of these lines beginning at bar 8 , the music is very similar melodically and harmonically. Pinel creates some anticipation in bars 11 to 13 where quaver rests break up the text which lingers on the words 'Aimons, cédons' (let us love each other). The ensuing chromaticism and swift changes in key might be symbolic of the grandiose display that line one of the text warns the lovers against: 'Fuyons la grandeur souveraine' ${ }^{70}$ However, the melismatic vocal sections are clearly not adhering to that philosophy:

Example 23, Pinel, 'Scène Pastorale', duo, bb.23-26.

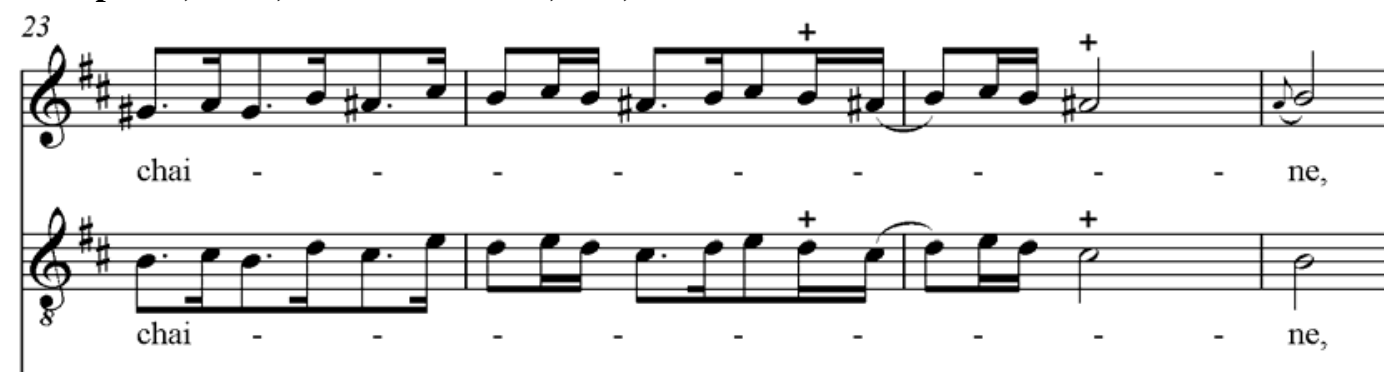

\section{CANTATILLE}

Pinel's cantatille, 'Le Printems', comprises two recitatives and two airs, and is a delightful mixture of light-heartedness and bravura. In particular, the final air in 'Le Printems' is technically demanding with a virtuoso flûte ou violon part, as well as a challenging part for the singer, while still exuding a graceful style.

\footnotetext{
${ }^{69}$ Let us fear the intensity that in [our] pleasures/Our chain prepares for us. Pinel, Scène Pastorale, (1737). Catalogue no. 15. Volume II, p.26.

${ }^{70}$ Let us flee all grandiose display. Pinel, Scène Pastorale, (1737). Catalogue no. 15. Volume II, p.26.
} 
The opening recitative is secco, in which Pinel uses time signature changes, rests and rhythm to achieve a style of music that is very close to speech. ${ }^{71}$ The figured bass is less active, and comprises a combination of long notes which provide the harmony and short melodic flourishes to emphasise parts of the text and create interest: ${ }^{72}$

Example 24, Pinel, 'Le Printems', recitative 1, bb.1-5.

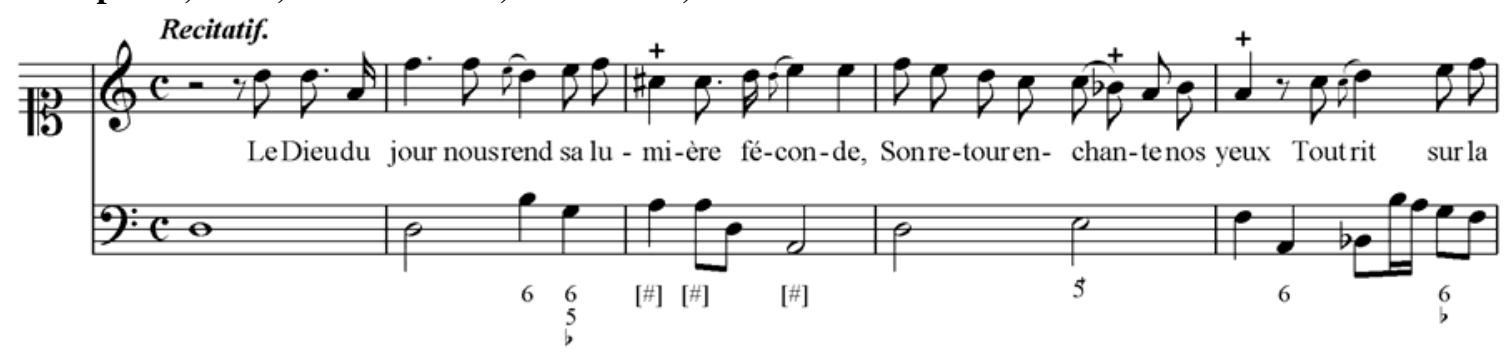

The second recitative begins in this manner also; however, in bar 11 it becomes mesuré which coincides with the text becoming more loving and reflective: 'Veux tu payer toujours les tendres feux/De mon coeur amoureux? ${ }^{, 73}$

Example 25, Pinel, 'Le Printems', recitative 2, bb.9-13.

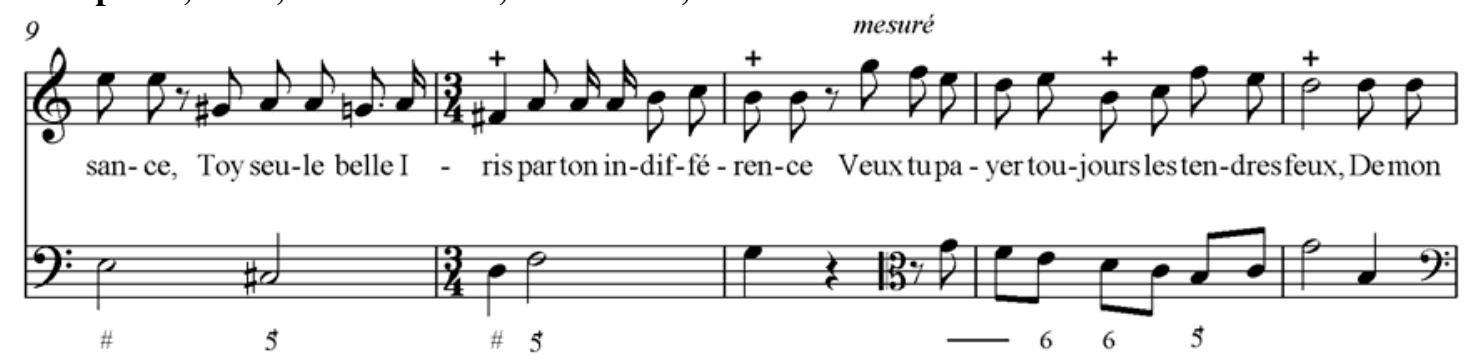

French cantatas and cantatilles, tended to exhibit more Italianate characteristics such as "long, flowing vocal lines, held notes in the voice, "echoes", mobile basses, either melodic or arpeggiated, and the use of more varied and more wilfully chromatic harmony. ${ }^{, 74}$ This certainly applies to 'Le Printems'. For example, in the airs, the bass line is very active and melodic. The music of the

\footnotetext{
${ }^{71}$ Secco recitative is an Italianate style, which is quick and freely performed in contrast to measured recitative, or mesuré, which is characteristically French and more strict tempo-wise, summed up in the following quotation: 'In order to capture the poetic effect of this sudden change of mood, the composer generally set that portion of the text in an aria-like style. These sections are analogous to little airs or ariettes because of the use of symmetrical rhythmic structure'. Vollen, 1982, pp.82 \& 87.

${ }^{72}$ Vollen, 1982, pp.83-84.

${ }^{73}$ Do you still wish to extinguish/The tender fires of my loving heart? Pinel, 'Le Printems', 1737. Catalogue no. 25. Volume II, p.55.

${ }^{74}$ Paul-Marie Masson, L'Opéra de Rameau (Paris, 1930), p.27 cited in Vollen, pp.53-54.
} 
first air corresponds to the poem's instruction for the shepherdesses to sing and dance:

Unissez vos danses légères

Au doux son de nos chalumeaux.

Que l'amour qui regne en nos âmes

Nous inspire de nouveaux sons. ${ }^{75}$

The bass line opens with a gay et gracieux melody which is echoed by the voice which enters on beat three of bar 9 . When the voice initially enters, the bass line remains silent, and enters again on beat three of bar 10 echoing the voice's leap of a perfect fourth. Throughout this air, the bass part creates varying textures, with alternating polyphony and homophony:

Example 26, Pinel, 'Le Printems', air, bb. 9-16.

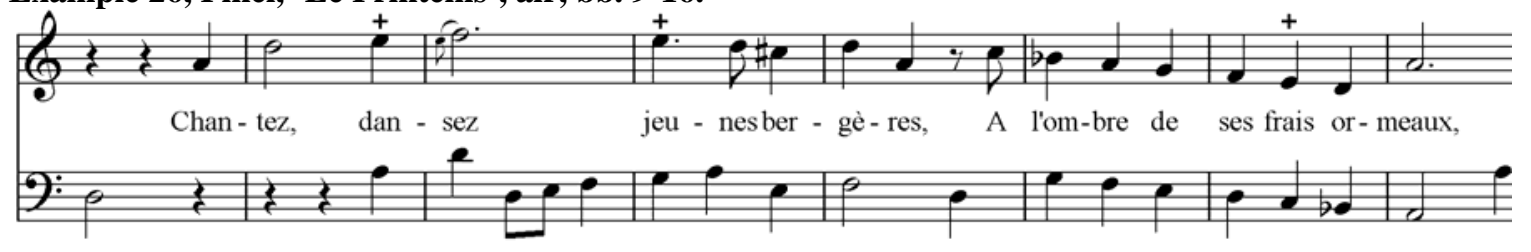

Harmonic sequence is another characteristic found in this air, an example of which can be heard in bars 9 to 19 and 20 to $27 .^{76}$

The final air is the second piece in Pinel's collection that is in da capo form, and which has a part for treble instrument, giving the designation, Flute ou Violon. Instrumental parts in French cantatas were usually written for flute or violin, and given that the cantatille was a miniature version of the cantata, it is characteristic of this genre also.

Interestingly, the final air in 'Le Printems' and Pinel's air sérieux 'Printems' not only share a name, but they also share similar characteristics and motivic development:

Example 27, Pinel , 'Printems', bb.1-3.

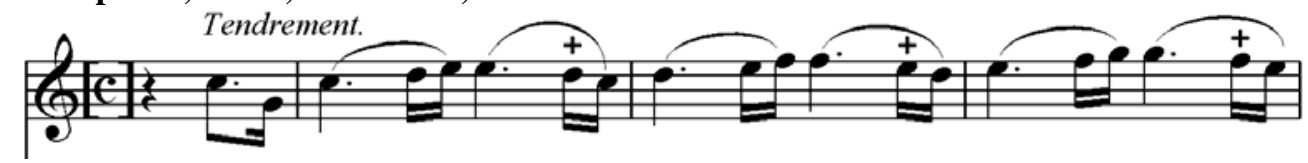

\footnotetext{
${ }^{75}$ Join your graceful dances/With the sweet sound of your pipes./Let love which reigns in our souls/Inspire us to new sounds. Pinel, 'Le Printems', 1737. Catalogue no. 25. Volume II, p.55. ${ }^{76}$ Vollen, 1982, p.52.
} 
Example 28, 'Le Printems' bb.1-2.

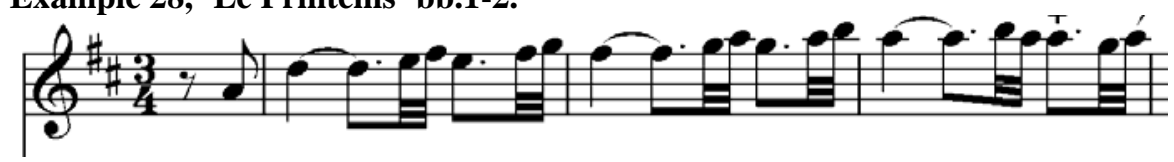

Their opening motifs are strikingly similar despite having a different time signature and key signature. They both ascend in a stepwise fashion, framed by quick flourishes with a turn-like quality. Like 'Printems', a motto opening is employed in the final air of the cantatille, and once again, the vocal part is anticipated by the instrumental introduction. What is more, in bars 2 to 5 , the bass part also imitates the treble opening before continuing independently. The idea that the treble instrument signifies the birds being spoken of in the text can be applied in this air also: 'Doux Rossignols chantez dans ces boccages, /Chantez votre bonheur, je n'en suis point jaloux'. ${ }^{77} \mathrm{~A}$ 'call and answer' passage for the voice and instrument, employed a similar manner to 'Printems' ('Rossignols vous chantez'), occurs in bars 26 to 37 on the word 'chantez' (sing). Appropriately, when the voice sings 'Redoublez vos divins accens', ${ }^{78}$ the instrumental part reverts to the motif that opened the air, further suggesting that the treble instrument plays the role of the nightingale.

\footnotetext{
${ }^{77}$ Sweet Nightingales, sing in these groves,/Sing of your happiness, of which I am not at all jealous. Pinel, 'Le Printems', 1737. Catalogue no. 25. Volume II, p.55.

${ }^{78}$ Redouble your heavenly notes. Pinel, 'Le Printems', 1737. Catalogue no. 25. Volume II, p.55.
} 


\section{Conclusion}

The eighteenth-century French air is a huge topic that extends far beyond the scope of this study and information on this genre remains a new field of research. Until recently, the air has, on the whole, been viewed and studied mainly on a broad scale, and individual airs have not been given thorough attention. One of the reasons that the eighteenth-century French air has been neglected for so long is because the focus has instead been on another fashionable genre which flourished in the final years of Louis XIV's reign: the cantate française. Furthermore, the vast quantity of airs from the seventeenth and eighteenth centuries, and the common belief that the music of airs is nothing more than the equivalent of today's pop music, has contributed to the inattention given to the French air. ${ }^{1}$ With the recently-published studies of Sebastien de Brossard's airs, it is evident that the airs of individual composers deserve greater focus. ${ }^{2}$ Dr. Greer Garden is currently working on the airs of one of the major songwriters from this period, Jean-Baptiste de Bousset, however, there remain numerous other composers worthy of similar research.

Julie Anne Sadie in her 1986 chapter, 'Musiciennes of the Ancien Régime', mentions Julie Pinel's Nouveau recueil, singling out one of the airs sérieux for its contemporary style. ${ }^{3}$ However, it was not until 2007 that Pinel's collection is again referred to, this time in closer examination, by the musical group ' $\mathrm{La}$ Donna Musicale' who published a recording of airs by Julie Pinel and other Parisian women, who included Elisabeth Jacquet de La Guerre, Mesdemoiselles Herault, Herville, Denis, and Bataille, and two unidentified women. ${ }^{4}$ It is significant that the release of this recording was so recent, because it highlights that little by little, the canon is expanding.

The present study has examined the life and Nouveau recueil of Mademoiselle Julie Pinel, within the social, literary and musical context of eighteenth-century

\footnotetext{
${ }^{1}$ Eastwood, 1984, p.85.

${ }^{2}$ Garden, 2005, pp.355-372.

${ }^{3}$ Sadie, 1986.

${ }^{4}$ The Pleasures of Love and Libation: Airs by Julie Pinel and other Parisian women, directed by Laury Gutiérrez (La Donna Musicale - LA 07103: Boston, 2007).
} 
France. It was common for children to follow the musical paths of their parents and succeed them in employment, as is the case with Julie Pinel. The example of the Pinel family illustrates that it was not only the King who had a musical establishment, at a time when princely courts of the period in France sought to emulate the royal court in this manner. The patronage of Charles de Rohan, Prince de Soubise, provided Pinel with the means to publish the collection of music at the centre of this research, of which a modern edition has been produced as a component of this research. Her connection to the Prince de Soubise, alongside the flourishing salon culture in eighteenth-century Paris, suggests that the music found in the collection may have found voice in court and in the homes of the nobility.

Special note is given to Pinel's authorship in her Nouveau recueil which provides evidence that she worked in various spheres as a composer, poet, harpsichord teacher, ${ }^{5}$ and most likely performer, remarkable achievements for a musicienne at a time when ambiguity and debate surrounded the role of women as professionals.

Pinel's forward-thinking style is illustrated in her poetry, in which a female poetic voice governs, framing the common themes found in eighteenth-century airs. The musical language of her Nouveau recueil is varied, displaying the influence of Italian traits, as well as drawing on the traditions of Sicard and Lambert. We have seen that the collection includes a range of air types, and her style of composition ranges from simple to technically demanding. The scène pastorale and cantatille attest to Pinel's awareness of the vogues in Parisian society respectively, of the musical eglogue, and the sequel to the cantata.

The nature of the opera she wrote awaits discovery. It has not yet been traced in any of the collections in the Parisian region. ${ }^{6}$ The possibility that Pinel composed yet more music is a question that remains unanswered. The collection that we do have provides a privileged glimpse into the life of a woman with immense talent and capability which is recognised on the recording mentioned above, which

\footnotetext{
${ }^{5}$ This is according to Boisgelou. See Chapter 1, pp.7-8.

${ }^{6}$ Refer to Chapter 1, footnote 21.
} 
includes Julie Pinel's name in its title and which has more airs by her than any other woman. ${ }^{7}$ Perhaps the cantatas believed to have been written by Pinel, will be uncovered one day. Until such a time, there is great hope that this study will inspire the performance of Julie Pinel's compositions, which deserve to be acknowledged alongside those of other eighteenth-century composers of airs.

\footnotetext{
${ }^{7}$ The recording includes the following airs: 'Printems', 'Boccages frais', 'Echos indiscrets, taisez vous’, 'Le Printems’, 'Scène Pastorale', and 'Pourquoy le berger qui m’engage’.
} 


\section{Appendix 1 Catalogue}

This catalogue itemises the contents of Julie Pinel's Nouveau recueil d'airs sérieux et à boire à une et deux voix, de Brunettes à 2 dessus, scène pastorale, et cantatille avec accompagnement. The style and terminology of the PhilidorOeuvre catalogue of the Centre de Musique Baroque de Versailles is followed, providing information on genre and the musical aspects of each piece, alongside their full texts. The fields of the catalogue are outlined below.

\section{Auteur}

The composer of the music is named.

\section{Auteur du texte}

The composer of the literary text is named where possible.

\section{Titre oeuvre}

This category gives the title of each piece, which in most cases is the first line of the given air.

\section{Effectif général}

The forces used are listed.

\section{Code incipit}

The music incipit provides the pitches for the first line of text in each piece in order to provide recognition for each piece. The number 1 indicates the tonic note and a space indicates a new bar.

\section{Texte incipit}

The text incipit provides the first line of text as it is found in the original source. 


\section{Source A}

There is only one known source for this collection, which has been listed in this category under each air.

\section{Genre musicale}

This category specifies the type of piece being examined, such as air sérieux, air à boire, scène pastorale, and cantatille. The airs are further classified in some cases with categories such as brunette, musette, and récit de basse.

\section{Notes musique}

For each air, information is presented regarding its key, expressive markings and time signature/s.

\section{Texte}

The full text of each piece is included.

\begin{tabular}{|c|c|}
\hline $\begin{array}{l}\mathbf{1} \\
\text { auteur }\end{array}$ & PINEL, Julie \\
\hline auteur du texte & PINEL, Julie \\
\hline titre oeuvre & air PRINTEMS \\
\hline effectif général & ut1, fl / bc \\
\hline code incipit & 15133212237712 \\
\hline texte incipit & Rossignols vous chantez les douceurs du printems, \\
\hline source $A$ & $\begin{array}{l}\text { AIR SÉRIEUX } \\
\text { in } \\
\text { PINEL, Julie } \\
\text { Nouveau recueil d'airs sérieux et à boire } \\
\text { Paris, Veuve Boivin, Le Clerc, } 1737 \\
\text { F-Pn / Vm7 } 629 \\
\text { pp.1-4 }\end{array}$ \\
\hline genre musicale & air sérieux \\
\hline notes musique & C Major, Tendrement, 2 \\
\hline texte & $\begin{array}{l}\text { Rossignols vous chantez les douceurs du printems, } \\
\text { Le tendre amour qui vous anime, } \\
\text { Par vos aimables sons s'exprime, } \\
\text { Et les rend encor plus charmans. } \\
\text { Mon coeur hélas est aussy la victime } \\
\text { Du Dieu que célébrent vos chans. } \\
\text { Mais pour moy ce seroit un crime } \\
\text { De laisser éclatter les feux que je ressens. } \\
\text { Chantez les douceurs du printems, } \\
\text { Heureux oiseaux, l'amour qui vous anime } \\
\text { Par vos aimables sons s'exprime, } \\
\text { Et les rend encor plus charmans. }\end{array}$ \\
\hline
\end{tabular}




\begin{tabular}{|ll|}
\hline 2 & \\
auteur & PINEL, Julie \\
titre oeurre & PINEL, Julie \\
effectif général & air MES YEUX NE VERSEZ PLUS DE PLEURS \\
code incipit & ? bc \\
texte incipit & Mes yeux ne versez plus de pleurs \\
source A & AIR SÉRIEUX \\
& in \\
& PINEL, Julie \\
& Nouveau recueil d'airs sérieux et à boire \\
& Paris, Veuve Boivin, Le Clerc, 1737 \\
& F-Pn / Vm7 629 \\
& pp.5-6 \\
air sérieux & E Minor, Tendrement, 3 \\
genre musicale & Mes yeux, ne versez plus de pleurs; \\
notes musique & Tircis vient calmer mes allarmes. \\
texte & Loin de lui montrer mes douleurs \\
& A son aspect brillez de nouveaux charmes. \\
& L'absence d'un objet aimé \\
& Accable un coeur fidelle et tendre, \\
& Mais quand l'amour veut nous le rendre \\
& Qu'il est doux de revoir ce qui nous a charmé. \\
& Mes yeux, ne versez plus de larmes. \\
& Tircis vient finir mes malheurs \\
& Loin de lui montrer mes douleurs \\
& A son aspect brillez de nouveaux charmes. \\
& \\
& \\
& \\
&
\end{tabular}

\begin{tabular}{|ll|}
\hline 3 & \\
auteur & PINEL, Julie \\
auteur du texte & PINEL, Julie \\
titre oeuvre & air ECHOS INDISCRETS TAISEZ VOUS \\
effectif général & ut1 / bc \\
code incipit & 13231171 \\
texte incipit & Echos indiscrets taisez vous, \\
source A & AIR SÉRIEUX \\
& in \\
& PINEL, Julie \\
& Nouveau recueil d'airs sérieux et à boire \\
& Paris, Veuve Boivin, Le Clerc, 1737 \\
& F-Pn / Vm7 629 \\
& pp.6-7 \\
& air sérieux \\
& G Minor, 2, 3/2, 2, 3/2, 2 \\
Echos indiscrets, taisez-vous, \\
genre musicale \\
notes musique & Les Dieux mêmes seroient jaloux \\
texte & De voir mon sort égal a leur bonheur Suprême. \\
& Si Venus connoissoit l'objet de mon amour \\
& Elle abandonneroit le céleste séjour, \\
& Pour m'arracher un amant que j'adore. \\
& Ah, cachons bien le feu qui me dévore, \\
& On trouveroit mon sort trop doux \\
\hline
\end{tabular}


Echos indiscrets, taisez vous,

Faut-il vous le redire encore?

\begin{tabular}{|ll|}
\hline auteur & PINEL, Julie \\
auteur du texte & non identifié \\
titre oeuvre & air FUNESTE ENNEMY DE LA PAIX \\
effectif général & c1 / bc \\
code incipit & 1335771 1 \\
texte incipit & Funeste ennemy de la paix \\
source A & AIR SÉRIEUX \\
& in \\
& PINEL, Julie \\
& Nouveau recueil d'airs sérieux et à boire \\
& Paris, Veuve Boivin, Le Clerc, 1737 \\
& F-Pn / Vm7 629 \\
& p.8 \\
air sérieux & A Major, Tendrement, 3 \\
genre musicale & Funeste ennemy de la paix, \\
notes musique & Autheur de mes tristes allarmes, \\
texte & Perfide Amour, \\
& Tu ne te plais qu'à voir verser du sang, \\
& A voir couler des larmes. \\
La cruauté forge tes traits \\
Ils font naitre en nos coeurs l'espoir qui les abuse, \\
Et tu n'as un bandeau que pour servir d'excuse \\
Aux injustices que tu fais. \\
\end{tabular}

\begin{tabular}{|ll|}
\hline $\mathbf{5}$ & \\
auteur & PINEL, Julie \\
auteur du texte & PINEL, Julie \\
titre oeuvre & air AMANS CONSTANS \\
effectif général & ut1 / bc \\
code incipit & 513251275 \\
texte incipit & Amans constans vous pouvez boire \\
source A & AIR À BOIRE \\
& in \\
& PINEL, Julie \\
& Nouveau recueil d'airs sérieux et à boire \\
& Paris, Veuve Boivin, Le Clerc, 1737 \\
& F-Pn / Vm7 629 \\
& p.9 \\
genre musicale & air boire \\
notes musique & C Major, 3 \\
texte & Amans constans vous pouvez boire; \\
& L'amour n'en sera point jaloux, \\
& Et bien loin d'offenser sa gloire \\
& Croyez que son triomphe \\
& En deviendra plus doux. \\
& La beauté qui vous a sçu plaire \\
& Verra celebrer ses attraits, \\
& Et lors qu'elle prendra son verre, \\
& L'Amour y trempera ses traits. \\
&
\end{tabular}




\begin{tabular}{|ll|}
\hline 6 & \\
auteur & PINEL, Julie \\
auteur du texte & PINEL, Julie \\
titre oeuvre & air RUISSEAUX SUSPENDEZ VOTRE \\
effectif général & c1 / bc \\
code incipit & 3155 55432 171 7 \\
texte incipit & Ruisseaux, Suspendez vôtre cours \\
source A & AIR SÉRIEUX \\
& in \\
& PINEL, Julie \\
& Nouveau recueil d'airs sérieux et à boire \\
& Paris, Veuve Boivin, Le Clerc, 1737 \\
& F-Pn / Vm7 629 \\
& p.10 \\
air sérieux & A Minor, 2 \\
genre musicale & Ruisseaux, suspendez vôtre cours, \\
notes musique & Oiseaux cessez votre ramage, \\
texte & L'objet de mes tendres amours \\
& Est devenu volage: \\
L'ingrat vient de trahir sa foy. & Je croy de ma douleur tout doit être l'image! \\
& Qu'un silence effrayant regne dans ce boccage; \\
& Que tout devienne aussy triste que moy! \\
Le perfide me fuit, hé, quelle dure loy \\
Me force en le perdant a l'aimer davantage?
\end{tabular}

\begin{tabular}{|c|c|}
\hline $\begin{array}{l}7 \\
\text { auteur }\end{array}$ & PINFI Julie \\
\hline auteur du texte & non identifié \\
\hline titre oeuvre & air DE LA PHILOSOPHIE \\
\hline effectif général & fa4 \\
\hline code incipit & 123321711 \\
\hline texte incipit & De la philosophie \\
\hline source $A$ & $\begin{array}{l}\text { RECIT DE BASSE-TAILLE À BOIRE } \\
\text { in } \\
\text { PINEL, Julie } \\
\text { Nouveau recueil d'airs sérieux et à boire } \\
\text { Paris, Veuve Boivin, Le Clerc, } 1737 \\
\text { F-Pn / Vm7 } 629 \\
\text { p.11 }\end{array}$ \\
\hline genre musicale & $\begin{array}{l}\text { air à boire } \\
\text { recit de basse-taille }\end{array}$ \\
\hline notes musique & G Minor, Lentement, Un peu plus gay, Gay, 3, C, $3,2 / 4,3$ \\
\hline texte & $\begin{array}{l}\text { De la philosophie } \\
\text { J'ay formé je le pense un Sisthéme certain } \\
\text { Et j'ay pour le prouver à tout le genre humain } \\
\text { Et Bacchus et Silvie: } \\
\text { Pour braver du destin les biseares decrets } \\
\text { Le vin sçait me donner un courage invincible; } \\
\text { Et je ne connois point de plaisir plus sensible } \\
\text { Oue de suivre l'Amour quand il lance ses traits. }\end{array}$ \\
\hline
\end{tabular}




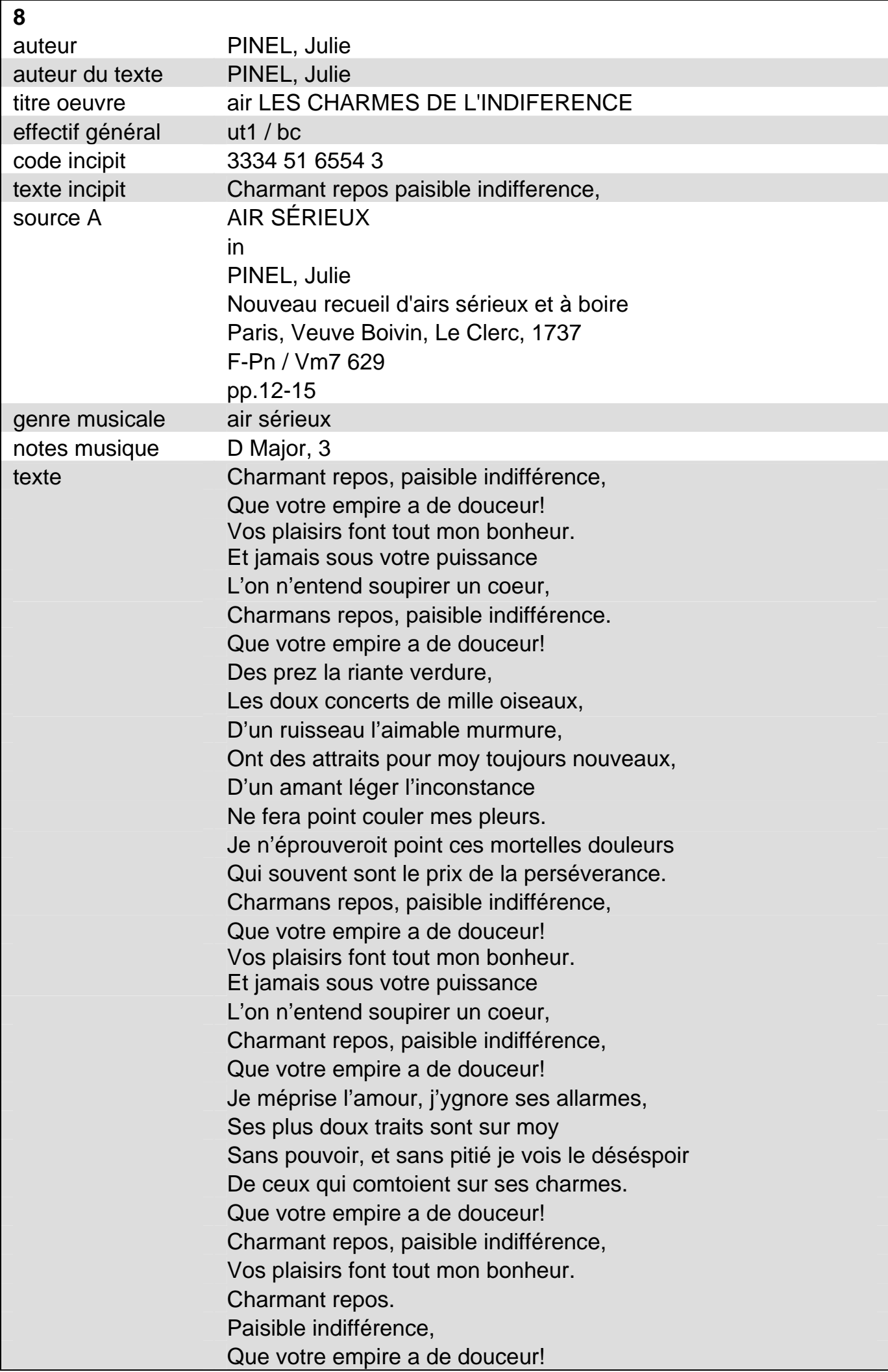

\section{9}

auteur PINEL, Julie

auteur du texte PINEL, Julie

titre oeuvre air MON CHER TROUPEAU SORTONS DE CE BOCCAGE

effectif général ut1 / bc 


$\begin{array}{|ll|}\text { code incipit } & 3345 \text { 325 1324 31 } \\ \text { texte incipit } & \text { Mon cher troupeau sortons de ce boccage, } \\ \text { source A } & \text { BRUNETTE } \\ & \text { in } \\ & \text { PINEL, Julie } \\ & \text { Nouveau recueil d'airs sérieux et à boire } \\ & \text { Paris, Veuve Boivin, Le Clerc, 1737 } \\ & \text { F-Pn / Vm7 629 } \\ & \text { p.15 } \\ \text { genre musicale } & \text { air sérieux } \\ & \text { brunette } \\ \text { notes musique } & \text { G Major, 3 } \\ \text { texte } & \text { Mon cher troupeau, sortons de ce boccage, } \\ & \text { Fuyons les bergers et les loups. } \\ & \text { Les uns sont à craindre pour vous, } \\ & \text { Et les autres pour moy le sont bien d'avantage. } \\ \end{array}$

\begin{tabular}{|c|c|}
\hline $\begin{array}{l}10 \\
\text { auteur }\end{array}$ & PINEL, Julie \\
\hline auteur du texte & non identifié \\
\hline titre oeuvre & air LORS QUE L'ON BOIT A MES AMOURS \\
\hline effectif général & ut1 / bc \\
\hline code incipit & 315554321717 \\
\hline texte incipit & Lors que l'on boit a mes amours \\
\hline source A & $\begin{array}{l}\text { AIR À BOIRE } \\
\text { in } \\
\text { PINEL, Julie } \\
\text { Nouveau recueil d'airs sérieux et à boire } \\
\text { Paris, Veuve Boivin, Le Clerc, } 1737 \\
\text { F-Pn / Vm7 } 629 \\
\text { p.16 }\end{array}$ \\
\hline notes source & $\begin{array}{l}\text { Same text set by Bousset, René Drouard de } \\
\text { RECUEIL D'AIRS SERIEUX ET A BOIRE, I } \\
\text { Paris, Auteur, Boivin, Le Clerc, } 1731 \\
\text { F-Pn / Vm7 } 624 \\
\text { p. } 29\end{array}$ \\
\hline genre musicale & air à boire \\
\hline notes musique & G Major, Tendrement, 3 \\
\hline texte & $\begin{array}{l}\text { Lors que l'on boit à mes amours } \\
\text { C'est à vous que l'on boit, adorable Silvie. } \\
\text { Ah que j'aurois l'âme ravie } \\
\text { Que je passerois d'heureux jours } \\
\text { Si l'on buvoit à moy Silvie } \\
\text { Lors que l'on boit à vos amours. }\end{array}$ \\
\hline
\end{tabular}

\begin{tabular}{|ll}
\hline 11 & \\
auteur & PINEL, Julie \\
auteur du texte & non identifié \\
titre oeuvre & air QUE TIRCIS EST CHARMANT \\
effectif général & ut1 / bc \\
code incipit & 516717 \\
texte incipit & Que Tircis est charmant \\
source A & $\begin{array}{l}\text { AIR SÉRIEUX } \\
\text { in }\end{array}$ \\
\hline
\end{tabular}




\begin{tabular}{|ll|} 
& PINEL, Julie \\
& Nouveau recueil d'airs sérieux et à boire \\
& Paris, Veuve Boivin, Le Clerc, 1737 \\
& F-Pn / Vm7 629 \\
& p.17 \\
genre musicale & air sérieux \\
notes musique & D Major, Tendrement, 3, C, 3 \\
texte & Que Tircis est charmant, et qu'il est amoureux; \\
& II me rend mille soins dont je suis allarmée. \\
& Ah, qu'il est dangereux \\
& Quand on est tendrement aimée, \\
& De sentir qu'un amant est digne d'être heureux. \\
\hline
\end{tabular}

\section{2}

\begin{tabular}{|c|c|}
\hline auteur & PINEL, Julie \\
\hline auteur du texte & non identifié \\
\hline titre oeuvre & air BUVONS LUCAS \\
\hline effectif général & ut1 / fa4 \\
\hline code incipit & 5127525334536432 \\
\hline texte incipit & Buvons Lucas mais buvons tant lui disoit grégoire en pintant \\
\hline source $A$ & $\begin{array}{l}\text { AIR À BOIRE } \\
\text { in } \\
\text { PINEL, Julie } \\
\text { Nouveau recueil d'airs sérieux et à boire } \\
\text { Paris, Veuve Boivin, Le Clerc, } 1737 \\
\text { F-Pn / Vm7 } 629 \\
\text { pp.18-19 }\end{array}$ \\
\hline genre musicale & $\begin{array}{l}\text { air à boire } \\
\text { duo }\end{array}$ \\
\hline notes musique & F Major, Vif, Lentement, 3, 2/4, \\
\hline texte & $\begin{array}{l}\text { Buvons Lucas, mais buvons tant, } \\
\text { Luy disoit Grégoire en pintant } \\
\text { Qu'il en soit parlé dans l'histoire: } \\
\text { Des Héros précédens surpassons la mémoire, } \\
\text { Le verre en main forçons leurs noms fameux } \\
\text { A ne plus marcher qu'apres ceux } \\
\text { Du grand Lucas et de Grégoire. }\end{array}$ \\
\hline
\end{tabular}

\begin{tabular}{|ll|}
\hline $\begin{array}{l}\text { 13 } \\
\text { auteur }\end{array}$ & PINEL, Julie \\
$\begin{array}{l}\text { titre oeuvre } \\
\text { effectif général }\end{array}$ & non identifié \\
code incipit & 554432 ( 3456751212217 \\
texte incipit & Apres m'avoir formé les plus aimables chaines, \\
source A & AIR SÉRIEUX \\
& in \\
& PINEL, Julie \\
& Nouveau recueil d'airs sérieux et à boire \\
& Paris, Veuve Boivin, Le Clerc, 1737 \\
& F-Pn / Vm7 629 \\
p.20 & air sérieux \\
genre musicale & D Minor, Tendrement, 3 \\
notes musique & Apres m'avoir formé les plus aimables chaines, \\
texte &
\end{tabular}


L'amour livre mon coeur aux plus cruels soupirs:

Ah si ses doux plaisirs font oublier ses peines,

Ses tourmens ne font pas oublier ses plaisirs.

\begin{tabular}{|ll|}
\hline 14 & \\
auteur & PINEL, Julie \\
auteur du texte & PINEL, Julie \\
titre oeuvre & air SOMBRES LIEUX OBSCURES FORRETS \\
effectif général & ut1 / bc \\
code incipit & 51731765 \\
texte incipit & Sombres lieux obscures forrets. \\
source A & AIR SÉRIEUX \\
& in \\
& PINEL, Julie \\
& Nouveau recueil d'airs sérieux et à boire \\
& Paris, Veuve Boivin, Le Clerc, 1737 \\
& F-Pn / Vm7 629 \\
& pp.21-22 \\
& air sérieux \\
& A Minor, Tendrement, 3 \\
genre musicale & Sombres lieux, obscures forrets, \\
notes musique & Vous paroissez sensible au tourment que j'endure; \\
texte & Quand vous abandonnez votre aimable parure \\
& Vous semblez partager tous mes ennuis secrets. \\
& Un triste éloignement m'arache à ce que j'aime, \\
& Mais si l'amour couronnant nos soupirs \\
& Nous rassemble en ces lieux au gré de nos désirs, \\
& Bois charmant, secondez une tendresse extrême \\
& De vos ombres, formez s'il ce peut la nuit même \\
& Pour mieux cacher l'excés de nos plaisirs. \\
& \\
& \\
&
\end{tabular}

\begin{tabular}{|c|c|}
\hline 15 & \\
\hline auteur & PINEL, Julie \\
\hline auteur du texte & PINEL, Julie \\
\hline titre oeuvre & SCENE PASTORALE \\
\hline effectif général & ut1, ? / bc \\
\hline code incipit & 5523156717 \\
\hline texte incipit & Belle Daphné je sçay votre secret \\
\hline source $A$ & $\begin{array}{l}\text { in } \\
\text { PINEL, Julie } \\
\text { Nouveau recueil d'airs sérieux et à boire } \\
\text { Paris, Veuve Boivin, Le Clerc, } 1737 \\
\text { F-Pn / Vm7 } 629 \\
\text { pp. } 22-29\end{array}$ \\
\hline genre musicale & scene pastorale \\
\hline notes musique & $\begin{array}{l}\text { D Minor, C, 3, C, 3, C, } 3 \\
\text { Air (bb.105-127), D Major, Lentement, Vivement, Lentement, } 2 \\
\text { Duo, D Major, } 3\end{array}$ \\
\hline texte & $\begin{array}{l}\text { Belle Daphné, je sçay votre secret } \\
\text { Vous disiez l'autre jour à la jeune Climeine } \\
\text { Que votre coeur pourroit céder sans peine, } \\
\text { A l'ardeur d'un amant discret, } \\
\text { Si c'est au plus constant que vous devez vous rendre. }\end{array}$ \\
\hline
\end{tabular}


Ah vous ne devez plus attendre,

Connoissez aujourd'huy

L'exces de mon amour;

Tout est paisible en ce séjour

Rien ne peut nous être contraire,

Non, vous qui sçavez tout charmer,

Vous m'instruirez dans l'art de plaire,

Je vous apprendray l'art d'aimer.

Que ce discours doit me surprendre

Iphis, vous bruleriez pour moy,

Que tardiez vous à me l'apprendre?

Hé, si quelqu'autre amant avoit reçeu ma foy

De quel succes votre flamme suivie?

Mon désespoir m'arracheroit la vie

Mais quel éffroy vient me saisir,

Quel est l'heureux rival qui prétend me ravir

L'unique objet qui receüs mon hommage,

Ah courrons le chercher, sans tarder d'avantage.

Cessez Iphis de vous troubler.

Ce rival supposé, qui vous a fait trembler,

Étoit l'ouvrage de ma crainte.

Rappellez votre espoir et pardonnez ma feinte.

Vous rendez la paix à mon coeur

En le troublant des plus douces allarmes,

Hattez-vous, cher objet, qu'un aveu plein de charmes

Acheve aujourd'huy mon bonheur.

Que voulez-vous encor et que puis-je vous dire;

C'est pour moy, dites vous, que votre coeur soupire.

Si d'un amour constant, vous êtes enflammé

Joignez-y l'espoir d'être aimé.

Que mon soir est charmant, trop aimable bergere,

Vous m'aimez, que je suis heureux,

Promettez-moy de n'être point légère

Vous aurez comblé tous mes voeux.

Je vous promets une flâme eternelle,

Mais quand je vous donne ma foy

Par un serment assurez-moy

Que votre coeur sera fidelle.

J'en atteste ces lieux à Pâlés consacrez,

Ces bois de nos bergers en tous tems revérez,

Puissent ces arbres verds dépouillez de verdure

Ne reprendre jamais leur aimable parure

Puissent ces lieux charmans être d'affreux déserts

$\mathrm{Si}$ jamais je brise mes fers.

Fuyons la grandeur souveraine,

Aimons, cédons à nos désirs,

Craignons l'éclat dans les plaisirs

Que nous prépare notre chaine.

\section{6}

auteur

PINEL, Julie

auteur du texte

PINEL, Julie

titre oeuvre air MUSETTE POUR UN BERGER

effectif général ut1 / bc 


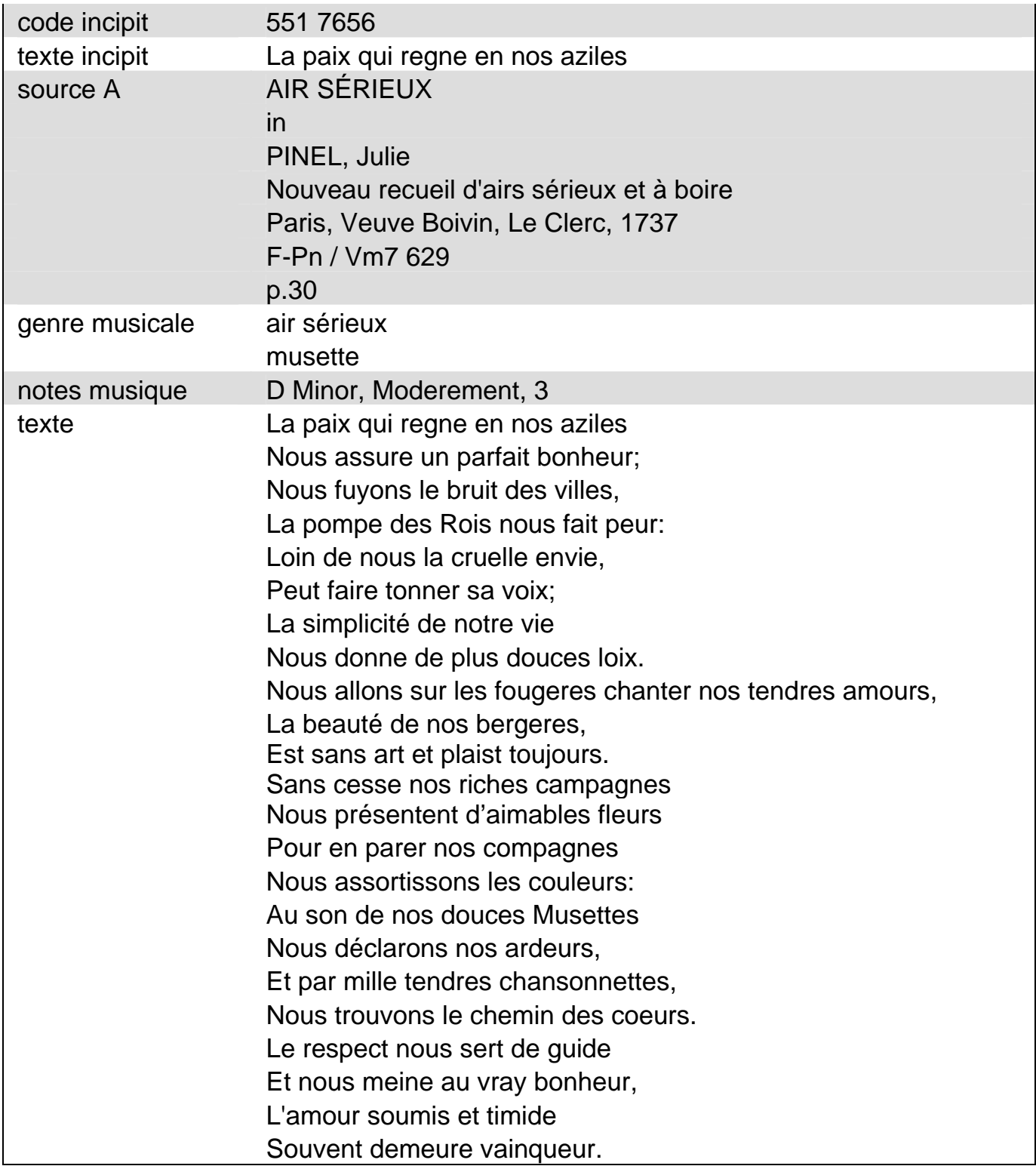

\begin{tabular}{|ll|}
\hline 17 & \\
auteur & PINEL, Julie \\
auteur du texte & non identifié \\
titre oeuvre & air MUSETTE POUR UNE BERGERE \\
effectif général & ut1 / bc \\
code incipit & 13217 15 \\
texte incipit & Douce innocence \\
source A & AIR SÉRIEUX \\
& in \\
& PINEL, Julie \\
& Nouveau recueil d'airs sérieux et à boire \\
& Paris, Veuve Boivin, Le Clerc, 1737 \\
& F-Pn / Vm7 629 \\
pp.32-33 \\
air sérieux \\
musette \\
notes musique & D Major, Gracieux et gay, 3 \\
texte & Douce innocence
\end{tabular}


Régne sur nos coeurs

Chere ignorance

Des biens séducteurs.

Ta jouissance

Conserve nos moeurs,

Et l'espérance

Des vaines grandeurs

N'a point de puissance,

Où I'on s'en tes faveurs:

Notre heureuse vie

Coule sans envie,

Nos bergers, contens,

Sont toujours constans.

Quand un amant jure

D'adorer nos yeux,

Sa foy simple et pure,

Nous assure mieux

Que lors qu'un parjure,

Atteste les Dieux.

\begin{tabular}{|ll|}
\hline $\mathbf{1 8}$ & \\
auteur & PINEL, Julie \\
auteur du texte & non identifié \\
titre oeuvre & air TENDRES AMANS QU'AMOUR ENGAGE \\
effectif général & ut1 / bc \\
code incipit & 3345 32312 31 \\
texte incipit & Tendres amans qu'amour engage \\
source A & AIR SÉRIEUX \\
& in \\
& PINEL, Julie \\
& Nouveau recueil d'airs sérieux et à boire \\
& Paris, Veuve Boivin, Le Clerc, 1737 \\
genre musicale & F-Pn / Vm7 629 \\
notes musique & air sérieux \\
texte & A Major, 3 \\
& Tendres amans qu'amour engage, \\
& Craignez de voir trop tôt courronner vos désirs; \\
& Ménager ce doux avantage \\
& Pour augmenter le prix de vos plésirs: \\
& L'amant constant bientôt languit, \\
\hline 19 & Son feu contraint s'acroist par l'espérance \\
auteur & Mais bien souvent du prix de la constance \\
auteur du texte & Naist le moment qui la détruit. \\
\hline titre oeuvre & \\
effectif général & PINEL, Julie \\
code incipit & air AMANS QUI LANGUISSEZ \\
texte incipit & 1 1715 64 45432 31 \\
source A & Amans qui languissez sous de pesan tes chaînes \\
& RECIT DE BASSE À BOIRE \\
in
\end{tabular}




\begin{tabular}{|ll|}
\multicolumn{1}{|l}{} & PINEL, Julie \\
& Nouveau recueil d'airs sérieux et à boire \\
& Paris, Veuve Boivin, Le Clerc, 1737 \\
& F-Pn / Vm7 629 \\
pp.34-35 \\
genre musicale & air à boire \\
& récit de basse \\
notes musique & C Minor, Gay, Doucement, Gay, 3/2, 2, 3, 2 \\
texte & Amans qui languissez sous de pesantes chaînes \\
& Redoublez vos soins, vos soupirs; \\
& Essayez de fléchir des rigueurs inhumaines, \\
& Pour arriver aux vrais plaisirs: \\
& Mais si l'objet qui vous engage \\
& Se rit encor de vos douleurs, \\
& C'est Bacchus qui sèche les pleurs \\
Des amans constants qu'on outrage & Buvez, oubliez vos malheurs, \\
Que sur un rouge bord \\
Ils fassent tous naufrage!
\end{tabular}

\begin{tabular}{|c|c|}
\hline 20 & \\
\hline auteur & PINEL, Julie \\
\hline auteur du texte & PINEL, Julie \\
\hline titre oeuvre & air BUVONS TOUS A LA RONDE \\
\hline effectif général & ut1 \\
\hline code incipit & 1234321 \\
\hline texte incipit & Buvons tous a la ronde \\
\hline source $A$ & $\begin{array}{l}\text { AIR À BOIRE } \\
\text { in }\end{array}$ \\
\hline & PINEL, Julie \\
\hline & Nouveau recueil d'airs sérieux et à boire \\
\hline & Paris, Veuve Boivin, Le Clerc, 1737 \\
\hline & F-Pn / Vm7 629 \\
\hline & p.35 \\
\hline genre musicale & $\begin{array}{l}\text { air à boire } \\
\text { fanfare }\end{array}$ \\
\hline notes musique & C Major, 9/8 \\
\hline texte & Buvons tous à la ronde \\
\hline & Qu'on nous verse toujours: \\
\hline & Puisse autant que le monde \\
\hline & Durer ce vin et nos amours! \\
\hline & Petit dieu de Cythere \\
\hline & Rends hommage à Bacchus: \\
\hline & Les faveurs de ta mére \\
\hline & Se doivent souvent à son jus. \\
\hline & Iris à cette table \\
\hline & Détermine mon choix: \\
\hline & Que sa voix adorable \\
\hline & Amour-met de coeurs sous tes loix. \\
\hline
\end{tabular}

\section{1}

auteur

PINEL, Julie

auteur du texte non identifié

titre oeuvre

air BRUNETTE A DEUX DESSUS 


$\begin{array}{|ll|}\text { effectif général } & \text { ut1, ut1 / bc } \\ \text { code incipit } & \text { 134 24 4342 31 } \\ \text { texte incipit } & \text { Boccages frais aimable solitude, } \\ \text { source A } & \text { AIR SÉRIEUX } \\ & \text { in } \\ & \text { PINEL, Julie } \\ & \text { Nouveau recueil d'airs sérieux et à boire } \\ & \text { Paris, Veuve Boivin, Le Clerc, 1737 } \\ & \text { F-Pn / Vm7 629 } \\ & \text { pp.36-39 } \\ \text { genre musicale } & \text { air sérieux } \\ & \text { brunette } \\ \text { notes musique } & \text { A Major, Tendrement, 3 } \\ \text { texte } & \text { Boccages frais, aimable Solitude, } \\ & \text { Qui d'un coeur amoureux charmez l'inquiétude, } \\ & \text { Riches présens de Flore, ornemens de ces lieux } \\ & \text { Que l'aurore embellit pour enchanter les yeux: } \\ & \text { Habitans de ces bois, oiseaux et vous fontaines, } \\ & \text { Qui laissez à vos Eaux des routes incertaines, } \\ & \text { Séjour heureux, Azile de la paix, } \\ & \text { Quand je vois mon amant que vous avez d'attraits. } \\ & \text { Mais je l'entens chanter sur sa Musette, } \\ & \text { Le moment fortunez qui luy rend sa Lisette, } \\ & \text { J'apperçois son troupeau déja je vois son chien } \\ & \text { Pour garder nos moutons se joindre avec le mien: } \\ & \text { Amour hâte ses pas, que l'espoir le plus tendre } \\ & \text { A mes ardens desirs, le presse de se rendre } \\ & \text { Charmans oiseaux, redoublez vos concerts, } \\ \text { Et que de nos plaisirs retentissent les airs. }\end{array}$

\begin{tabular}{|ll|}
\hline 22 & \\
auteur & PINEL, Julie \\
auteur du texte & PINEL, Julie \\
titre oeuvre & air AIR A BOIRE A DEUX VOIX EGALES \\
effectif général & fa4, fa4 \\
code incipit & 315517 \\
texte incipit & Celimeine a changé, \\
source A & AIR À BOIRE \\
& in \\
& PINEL, Julie \\
& Nouveau recueil d'airs sérieux et à boire \\
& Paris, Veuve Boivin, Le Clerc, 1737 \\
& F-Pn / Vm7 629 \\
& pp.40-41 \\
genre musicale & air à boire \\
& Duo \\
notes musique & D Minor, Lentement, Gay, Vif, Gay, C, 3, C, 2, C, 3 \\
texte & Célimeine à changé, \\
& Changeons à notre tour, \\
& Dégageons nous d'une fatale chaîne, \\
& Laissons désormais l'inhumaine, \\
& Se livrer aux transports \\
& De son nouvel amour: \\
& Cher Bacchus à jamais,
\end{tabular}


Je chanteray ta gloire;

Viens combattre en mon coeur

Un trop charmant poison, achèves,

Dieu puissant

Si je perds la raison

Que ce soit à force de boire.

\begin{tabular}{|ll|}
\hline 23 & \\
auteur & PINEL, Julie \\
auteur du texte & PINEL, Julie \\
titre oeuvre & air BRUNETTE A DUEX DESSUS \\
effectif général & ut1, ut1 / bc \\
texte incipit & 5545 342 31 \\
source A & Pourquoy le berger qui m'engage, \\
& AIR SÉRIEUX \\
& in \\
& PINEL, Julie \\
& Nouveau recueil d'airs sérieux et à boire \\
& Paris, Veuve Boivin, Le Clerc, 1737 \\
& F-Pn / Vm7 629 \\
& pp.42-44 \\
air sérieux \\
brunette \\
notes musique & A Minor, Tendrement, 3 \\
texte & Pourquoy le berger qui m'engage, \\
& Vient-il de ralentir ses feux: \\
& Hélas, s'il doit rompre ses noeuds \\
& Amour, viens me rendre volage. \\
& Faut-il que son coeur se dégage, \\
& Si tost que je reçois ses voeux: \\
& Hélas, s'il doit rompre ses noeuds \\
& Vole Amour, et me rends volage. \\
En vain je ressens cet outrage; \\
Mon coeur n'est pas moins amoureux: \\
L'ingrat peut bien rompre ses noeuds, \\
Mais je ne puis être volage.
\end{tabular}

24

auteur

PINEL, Julie

auteur du texte non identifié

titre oeuvre air TROP LONGTEMS A BACCHUS

effectif général ut1, fa4

code incipit

135453

texte incipit

Trop longtems a Bacchus

source A AIR À BOIRE

in

PINEL, Julie

Nouveau recueil d'airs sérieux et à boire

Paris, Veuve Boivin, Le Clerc, 1737

F-Pn / Vm7 629

pp.45-46

genre musicale

air à boire

duo

notes musique

G Major, Gayement, Lentement, Vif, Moins vif, 3, 2, 2/4, 2, C 
texte

Trop longtems à Bacchus j'ay disputé la gloire

De triompher de mon ardeur:

Si ce Dieu, devenu vainqueur,

Sur le cruel amour remporte la victoire

Je jure d'immoller aux pieds de ses autels

Ce funeste ennemy du repos des mortels.

\begin{tabular}{|c|c|}
\hline 25 & \\
\hline auteur & PINEL, Julie \\
\hline auteur du texte & PINEL, Julie \\
\hline titre oeuvre & LE PRINTEMS \\
\hline effectif général & ut1 / bc \\
\hline code incipit & 1153312377122 \\
\hline texte incipit & Le Dieu du jour nos rend sa lumière féconde, \\
\hline source $A$ & $\begin{array}{l}\text { CANTATILLE } \\
\text { in } \\
\text { PINEL, Julie } \\
\text { Nouveau recueil d'airs sérieux et à boire } \\
\text { Paris, Veuve Boivin, Le Clerc, } 1737 \\
\text { F-Pn / Vm7 } 629 \\
\text { pp.47-59 }\end{array}$ \\
\hline genre musicale & cantatille \\
\hline notes musique & $\begin{array}{l}\text { Recitatif, D Minor, C, 3, 2, C } \\
\text { Air, D Minor, Gay et gracieux, } 3 \\
\text { Recitatif, A Minor, mesuré, C, 3, C, 3, C } \\
\text { Air, A Minor, } 3\end{array}$ \\
\hline texte & $\begin{array}{l}\text { Recitatif: Le Dieu du jour nos rend sa lumière féconde, } \\
\text { Son retour enchante nos yeux } \\
\text { Tout rit sur la terre et sur l'onde, } \\
\text { Tout semble renaitre en ces lieux. } \\
\text { Le Zéphir va s'unir à Flore, } \\
\text { Bientost de leur tendres amours } \\
\text { Nous allons voir éclore } \\
\text { Mille fleurs avec les beaux jours... } \\
\text { Air: Chantez, dansez jeunes bergères, } \\
\text { A l'ombre de ces frais ormeaux, } \\
\text { Unissez vos danses légères } \\
\text { Au doux son de nos chalumeaux. } \\
\text { Que l'amour qui regne en nos âmes } \\
\text { Nous inspire de nouveaux sons. } \\
\text { Célébrons l'ardeur de nos flâmes } \\
\text { Par les plus aimables chansons. } \\
\text { Recitatif: Déja la riante verdure, } \\
\text { Fruit de l'haleine des Zéphirs, } \\
\text { Embellit toute la nature, et rameine } \\
\text { En ces lieux les jeux et les plaisirs, } \\
\text { Tout ressent de l'amour la Suprême puissance, } \\
\text { Toy seule belle Iris par ton indifférence } \\
\text { Veux tu payer toujours les tendres feux } \\
\text { De mon coeur amoureux? } \\
\text { Écoute les ramages } \\
\text { De ces heureux oiseaux } \\
\text { Ils t'invittent sous ces feuillages } \\
\text { A soulager mes meaux. }\end{array}$ \\
\hline
\end{tabular}


Air: Doux Rossignols chantez dans ces boccages, Chantez votre bonheur, je n'en suis point jaloux. Que vos chants amoureux deviennent les présages D'un plaisir qui me rend aussy content que vous Attendrissez mon aimable inhumaine;

Peignez luy l'ardeur que je sens;

Qu'elle partage enfin ma peine

Redoublez vos divins accens.

\begin{tabular}{|ll|}
\hline 26 & PINEL, Julie \\
auteur & PINEL, Julie \\
titre oeuvre & air QUE LES MORTELS SONT MISERABLES \\
effectif général & fa4 \\
code incipit & 111 3434 2 1 \\
texte incipit & Que les mortels sont miserables \\
source A & RECIT DE BASSE À BOIRE \\
& in \\
& PINEL, Julie \\
& Nouveau recueil d'airs sérieux et à boire \\
& Paris, Veuve Boivin, Le Clerc, 1737 \\
& F-Pn / Vm7 629 \\
& p.60 \\
& air à boire \\
& récit de basse \\
genre musicale & Quajor, Lentement, vif, Lentement, vif, 2, 2/4, 2, C \\
& $\begin{array}{l}\text { S'écrioit Lucas en fureur, } \\
\text { notes musique }\end{array}$ \\
texte & Unaque jour leur inspire une nouvelle erreur \\
& $\begin{array}{l}\text { Insensez, qui voulez combattre un sort malin, } \\
\text { Ce n'est ny l'amour ny la gloire } \\
\text { Qui nous font un heureux destin, } \\
\text { Pour moy tous mes projets se tournent à bien boire. }\end{array}$ \\
\hline
\end{tabular}

\begin{tabular}{|ll|}
\hline 27 & \\
auteur & PINEL, Julie \\
titre oeur du texte & non identifié \\
effectif général & air DE RICHESSES AMY JE NE SUIS POINT JALOUX \\
code incipit & ut1 / bc \\
texte incipit & De richésses amy je ne suis point jaloux, \\
source A & AIR SÉRIEUX \\
& in \\
& PINEL, Julie \\
& Nouveau recueil d'airs sérieux et à boire \\
& Paris, Veuve Boivin, Le Clerc, 1737 \\
& F-Pn / Vm7 629 \\
& p.61 \\
genre musicale & air sérieux \\
notes musique & C Major, Gay, 3 \\
texte & De richésses amy je ne suis point jaloux, \\
& J'ay pour guide l'amour, \\
& Quel exemple est plus doux?
\end{tabular}


Ce Dieu content de son partage,

N'a pour bien qu'un carquois,

Des fleches un flambeau,

Satisfait de regner sur les coeurs qu'il engage.

S'il a du superflus

Ce n'est que son bandeau.

\begin{tabular}{|ll|}
\hline 28 & \\
auteur & PINEL, Julie \\
auteur du texte & non identifié \\
titre oeuvre & air POUR GUÉRIR SANS RETOUR LA PLUS VIVE BLESSURE \\
effectif général & fa4 \\
texte incipit & 15123 223432 31 \\
source A & Pour guerir sans retour la plus vive bléssure \\
& RECIT DE BASSE À BOIRE \\
& in \\
& PINEL, Julie \\
& Nouveau recueil d'airs sérieux et à boire \\
& Paris, Veuve Boivin, Le Clerc, 1737 \\
& F-Pn / Vm7 629 \\
genre musicale & air à boire \\
& récit de basse \\
notes musique & C Major, Gay, Lentement, C, 2, 3, 2, C \\
texte & Pour guérir sans retour la plus vive bléssure \\
& Le vin est un remede Hyppocratte l'assure: \\
& Cher amy, verse m'en tout plein \\
& Que dans cet élixir divin mon coeur blessé des traits d'Aminte, \\
& Trouve à jamais sa guérison. \\
& Oh l'aimable contre poison, \\
& Vidons encore cette pinte.
\end{tabular}

\begin{tabular}{|ll|}
\hline $\mathbf{2 9}$ & \\
auteur & PINEL, Julie \\
auteur du texte & PINEL, Julie \\
titre oeuvre & air DIEU DU VIN QU'ELLE EST DONC TA FATALLE \\
effectif général & PUISSANCE \\
code incipit & 31555111212 32 \\
texte incipit & Dieu du vin qu'elle est donc ta fatalle puissance, \\
source A & AIR À BOIRE \\
& in \\
& PINEL, Julie \\
& Nouveau recueil d'airs sérieux et à boire \\
& Paris, Veuve Boivin, Le Clerc, 1737 \\
& F-Pn / Vm7 629 \\
& pp.63-64 \\
genre musicale & air à boire \\
notes musique & E Minor, vif gay, C, 2, C, 2, 3 \\
texte & Dieu du vin quelle est donc ta fatalle puissance, \\
& Verrons-nous sur les coeurs s'étendre ton pouvoir, \\
& Et de tous nos amans ébranler la constance \\
& Ne nous reste-t'il plus d'éspoir: \\
& Viens amour, viens vanger notre commun outrage.
\end{tabular}


Quand mon Tircis tiendra le funeste breuvage

Qu'une étincelle de ton flambeau,

Tombant dans ce jus que j'abbhore,

Me rende l'amant que j'adore,

Et l'enflâme tout de nouveau.

\begin{tabular}{|ll|}
\hline 30 & \\
auteur & PINEL, Julie \\
auteur du texte & PINEL, Julie \\
titre oeuvre & air AH QUE L'HOMME EST SCAVANT \\
effectif général & fa4 \\
code incipit & 11166156 22343 1 \\
texte incipit & Ah que l'homme est sçavant disoit un jour grégoire, \\
source A & RECIT DE BASSE À BOIRE \\
& in \\
& PINEL, Julie \\
& Nouveau recueil d'airs sérieux et à boire \\
& Paris, Veuve Boivin, Le Clerc, 1737 \\
& F-Pn / Vm7 629 \\
g.65 \\
air à boire \\
notes musicale de basse \\
texte & D Minor, Gay, Gay, 2, C, 3, 2, 3, 3/2, 3 \\
& Ah que l'homme est sçavant, disoit un jour Grégoire, \\
& Et que son sort me semble beau quand je le vois \\
& Sur un fourneau travailler suivant un grimoire: \\
& Apres mille travaux l'on ne voit rien encor. \\
L'on fixe le mercure, on a beau me le dire, \\
Dans un creuset je vois mettre de l'or, \\
& Et de soufleur confus jamais ne l'en retire \\
& Moy, je ne suis ny si fou ny si vain, \\
Mais je scais soufler de bon vin.
\end{tabular}

\begin{tabular}{|ll|}
\hline 31 & \\
auteur & PINEL, Julie \\
auteur du texte & PINEL, Julie \\
titre oeuvre & air CHANSONETTE ANACREONTIQUE \\
effectif général & ut1 / fa4 \\
code incipit & 1324321 \\
texte incipit & L'autre jour pres d'un bosquet \\
source A & AIR SÉRIEUX \\
& in \\
& Nouveau recueil d'airs sérieux et à boire \\
& Paris, Veuve Boivin, Le Clerc, 1737 \\
& F-Pn / Vm7 629 \\
genre musicale & air sérieux \\
& vaudeville \\
notes musique & A Minor, Tendrement, 2 \\
texte & L'autre jour pres d'un bosquet \\
& J'allois cueillir des fleurettes \\
& C'étoit pour faire un bouquet \\
& De naissantes viollettes. \\
& Mais entendant soupirer.
\end{tabular}


Je voulus me retirer.

Je m'entendis appeller

D'une voix douce et plaintive

Où voulez-vous donc aller?

Qui peut vous rendre craintive?

Hélas bien loin de me füir,

Cherchez a me secourir!

J'approche donc en tremblant

Vers l'éppaisseur du feuillage,

J'y trouve un enfant charmant

Des pleurs baignoient son visage

Hélas di-je en gémissant

Qui vous rend si languissant?

Regarde, dit-il, ma main

Par cette épine blessé

Je m'offre à l'ôter soudain

Et sa douleur est passée, Mais pour prix de ma bonté

Il ravit ma liberté.

Le traitre d'un ris moqueur

Décoche un trait et s'envole.

Le trait me perce le coeur

Mais toute plainte est frivole

Qui craint un semblable tour

Doit à jamais füir l'amour. 


\section{Appendix 2}

\section{Chart of Voltaire's correspondence listing each reference to Charles de Rohan, Prince}

de Soubise

\begin{tabular}{|c|c|c|c|}
\hline Date & Letter & Correspondence & Details \\
\hline 15 July 1738 & $1488 n 2$ & Voltaire to Bonaventure Moussinot & $\begin{array}{l}\text { Soubise, Charles de Rohan, prince de, } \\
\text { employs La Marre }\end{array}$ \\
\hline 9 June 1745 & 2907 & Voltaire to Pierre Bobert Le Cornier de Cideville & In connection with Roy's satire \\
\hline 8 August 1757 & 6643 & Voltaire to Jean Robert Tronchin & Commands French army formed at Metz \\
\hline September 1757 & 6691 & Voltaire to Jean Robert Tronchin & Opposed by Frederick II \\
\hline September 1757 & 6693 & Voltaire to Elie Bertrand & Opposed by Frederick II \\
\hline $\begin{array}{l}22 \text { September } \\
1757\end{array}$ & 6697 & Voltaire to Louis François Armand Du Plessis, duc de Richelieu & Opposed by Frederick II \\
\hline $\begin{array}{l}25 \text { September } \\
1757\end{array}$ & 6704 & Voltaire to Frederick II, King of Prussia & Opposed by Frederick II; see note \\
\hline $\begin{array}{l}27 \text { September } \\
1757\end{array}$ & 6706 & Voltaire to Jean Robert Tronchin & Opposed by Frederick II; see note 3 \\
\hline 28 October 1757 & 6741 & $\begin{array}{l}\text { Sophia Friderika Wilhelmina of Prussia, margravine of Bayreuth, to } \\
\text { Voltaire }\end{array}$ & At Eisenach \\
\hline $\begin{array}{l}5 \text { November } \\
1757\end{array}$ & 6751 & Louise Dorothea of Meiningen, duchess of Saxe-Gotha, to Voltaire & In Gotha \\
\hline $\begin{array}{l}15 \text { November } \\
1757\end{array}$ & 6764 & Voltaire to Jean Robert Tronchin & Defeated at Rossbach \\
\hline $\begin{array}{l}17 \text { November } \\
1757\end{array}$ & 6768 & Voltaire to Jean Robert Tronchin & Defeated at Rossbach \\
\hline $\begin{array}{l}17 \text { November } \\
1757\end{array}$ & 6769 & Voltaire to François Tronchin & His cook reported missing \\
\hline November 1757 & 6771 & Voltaire to Charles Augustin Feriol, comte d'Argental & Brings discredit on the French \\
\hline
\end{tabular}




\begin{tabular}{|c|c|c|c|}
\hline $\begin{array}{l}20 \text { November } \\
1757\end{array}$ & 6774 & Voltaire to Nicolas Claude Thieriot & Brings discredit on the French \\
\hline $\begin{array}{l}2 \text { December } \\
1757\end{array}$ & 6795 & Voltaire to Charles Augustin Feriol, comte d'Argental & His defeat mentioned \\
\hline $\begin{array}{l}5 \text { December } \\
1757\end{array}$ & 6797 & Voltaire to Charlotte Sophia of Aldenburg, countess Bentinck & His defeat mentioned \\
\hline $\begin{array}{l}7 \text { December } \\
1757\end{array}$ & 6801 & Voltaire to Nicolas Claude Thieriot & His defeat mentioned \\
\hline $\begin{array}{l}10 \text { December } \\
1757\end{array}$ & 6807 & Voltaire to Claude Etienne Darget & Its state commented on by Voltaire \\
\hline $\begin{array}{l}11 \text { December } \\
1757\end{array}$ & 6811 & Voltaire to Jean Robert Tronchin & His defeat mentioned \\
\hline 5 January 1758 & 6859 & Voltaire to Marie Ursule de Klingin, comtesse de Lutzelbourg & His defeat mentioned \\
\hline 9 March 1758 & 6977 & Louise Dorothea of Meiningen, duchess of Saxe-Gotha, to Voltaire & $\begin{array}{l}\text { Its movements commented on by Louise of } \\
\text { Saxe-Gotha }\end{array}$ \\
\hline October 1758 & 7186 & Louise Dorothea of Meiningen, duchess of Saxe-Gotha, to Voltaire & Is near Altenburg \\
\hline $\begin{array}{l}26 \text { February } \\
1759\end{array}$ & 7429 & Voltaire to Jean Robert Tronchin & His appointment enquired about by Voltaire \\
\hline 12 March 1759 & 7468 & Frederick II, King of Prussia, to Voltaire & Mentioned by Frederick II \\
\hline 23 March 1759 & 7491 & François Louis Allamand to Voltaire & Includes a Swiss regiment \\
\hline 24 January 1761 & 8803 & Voltaire to G. L. Deodati de Tovazzi & $\begin{array}{l}\text { Soubise, Charles de Rohan, prince de, grand } \\
\text { nephew of Henri, duc de Rohan; his conduct } \\
\text { during military \& diplomatic career }\end{array}$ \\
\hline 25 January 1761 & 8804 & Voltaire to Etienne Noël Damilaville and Nicolas Claude Thieriot & $\begin{array}{l}\text { Soubise, Charles de Rohan, prince de, } \\
\text { mentioned in Voltaire's letter }\end{array}$ \\
\hline $\begin{array}{l}26 \text { February } \\
1762\end{array}$ & 9551 & Voltaire to François Achard Joumard Tison, marquis d'Argence & His faction causes Broglie's downfall \\
\hline 4 March 1762 & 9562 & Louise Dorothea of Meiningen, duchess of Saxe-Gotha, to Voltaire & Succeeds Broglie \\
\hline 4 January 1763 & 10068 & Voltaire to Gabriel Cramer & $\begin{array}{l}\text { Prince de Soubise relations with Voltaire; } \\
\text { subscribes to the Théâtre de } P \text {. Corneille }\end{array}$ \\
\hline 13 December & 10718 & Voltaire to Jean Le Rond d'Alembert & Soubise is sent the Traité sur la tolérance \\
\hline
\end{tabular}




\begin{tabular}{|c|c|c|c|}
\hline 763 & & & \\
\hline 3 March 1764 & 10906 & Countess Sabina von Bassewitz to Voltaire & mentioned \\
\hline $\begin{array}{l}9 \text { September } \\
1766\end{array}$ & 12656 & Voltaire to G.L. Deodati de Tovazzi & $\begin{array}{l}\text { Mentioned in Voltaire's letter to Deodati; } \\
\text { falsified in an edition of Voltaire's } \\
\text { correspondence }\end{array}$ \\
\hline $\begin{array}{l}19 \text { September } \\
1766\end{array}$ & 12686 & Voltaire to Etienne Noël Damilaville & $\begin{array}{l}\text { Falsified in an edition of Voltaire's } \\
\text { correspondence }\end{array}$ \\
\hline September 1766 & 12692 & G.L. Deodati de Tovazzi to Voltaire & Against which an attestation is obtained \\
\hline $\begin{array}{l}24 \text { September } \\
1766\end{array}$ & 12699 & Voltaire to Marie de Vichy de Chamrond, marquise Du Deffand & Expected to support Sirven \\
\hline October 1766 & 12713 & $\begin{array}{l}\text { Voltaire to Charles Augustin Feriol, comte d'Argental, and Jeanne } \\
\text { Grâce Bosc Du Bouchet, comtesse d'Argental }\end{array}$ & $\begin{array}{l}\text { Falsified in an edition of Voltaire's } \\
\text { correspondence }\end{array}$ \\
\hline November 1766 & 12762 & Voltaire to Antoine Maillet Du Clairon & $\begin{array}{l}\text { Falsified in an edition of Voltaire's } \\
\text { correspondence }\end{array}$ \\
\hline $\begin{array}{l}7 \text { November } \\
1766\end{array}$ & 12775 & Voltaire to Antoine Maillet Du Clairon & $\begin{array}{l}\text { Falsified in an edition of Voltaire's } \\
\text { correspondence }\end{array}$ \\
\hline 1 October 1767 & 13558 & Voltaire to François Gabriel Le Fournier, chevalier de Wargemont & He and his regiment praised \\
\hline $\begin{array}{l}15 \text { November } \\
1768\end{array}$ & 14357 & Charles de Rohan, prince de Soubise, to Voltaire & Grateful for his reception of French officers \\
\hline 16 January 1769 & 14472 & Voltaire to François Gabriel Le Fournier, chevalier de Wargemont & Voltaire on his letter \\
\hline 6 February 1769 & 14502 & Voltaire to Marie Louise Denis & Voltaire sends greetings to him \\
\hline 1 May 1769 & 14647 & Voltaire to François Gabriel Le Fournier, chevalier de Wargemont & $\begin{array}{l}\text { Intermediary for Voltair's correspondence } \\
\text { with Wargemont }\end{array}$ \\
\hline 7 July 1769 & 14755 & Voltaire to François Gabriel Le Fournier, chevalier de Wargemont & Who is in his regiment \\
\hline 10 August 1769 & 14832 & Marie Louise Denis to Voltiare & His relations with Mme Du Barry \\
\hline
\end{tabular}


Appendix 3

René Drouard de Bousset's air, 'Lors que l'on boit à mes amours' (1731)

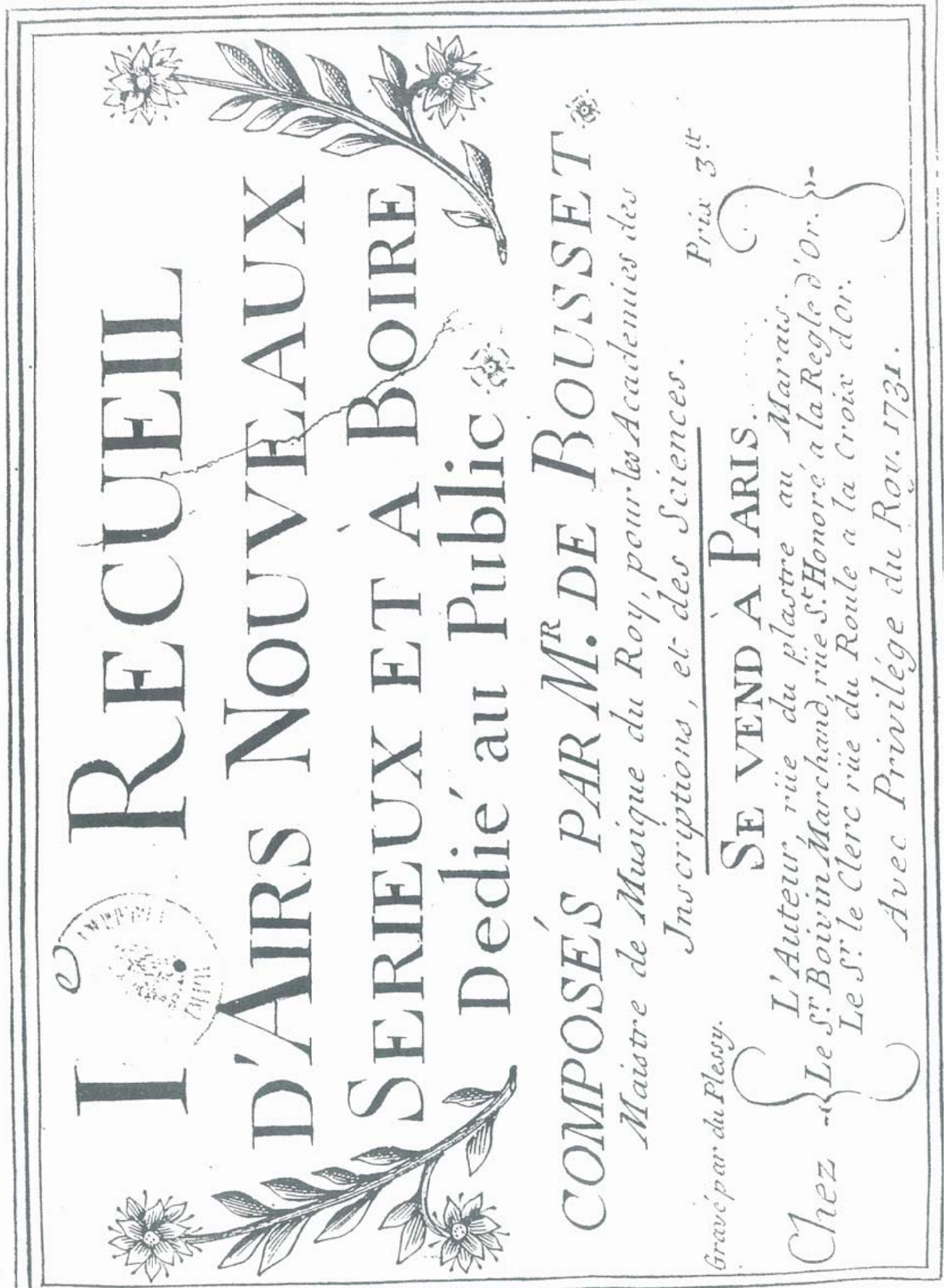




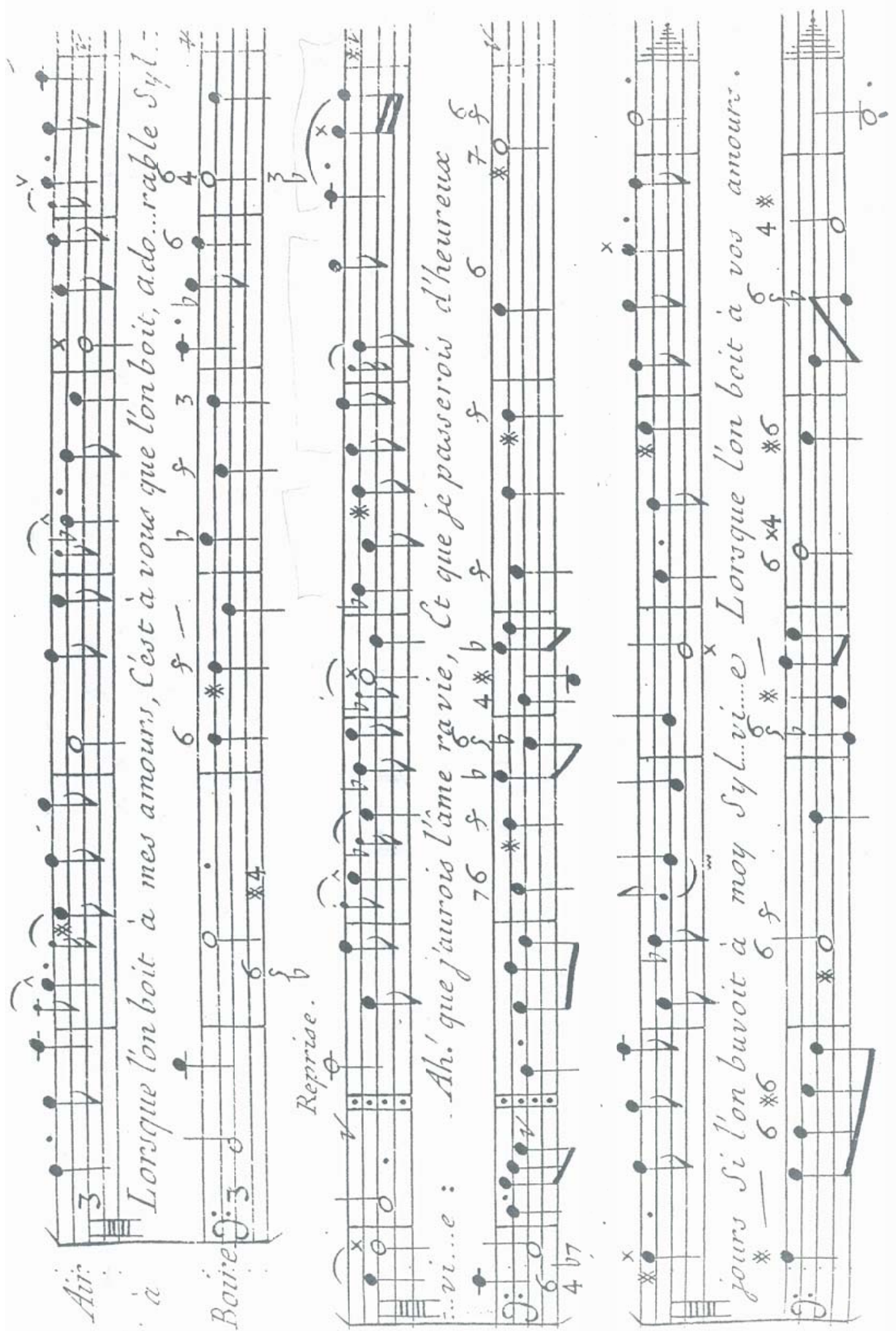




\section{Bibliography}

Adorno, Theodor. 'Bach Defended Against His Devotees'. Cambridge, MA: MIT Press.

Anthony, James R. 'Air and Aria added to French Opera'. Revue de Musicologie. Vol. 77, no. 2, 1991, pp. 201-219.

_Lully's Airs - French or Italian’. Musical Times. Vol. 128, no. 1729, March 1987, pp.126-129.

_French Baroque Music. London: B.T. Batsford, 1978.

Antoine, Michel. Le gouvernement et l'administration sous Louis XV: dictionnaire biographique. Paris: Éditions du Centre national de la recherche scientifique, 1978.

Auld, Louis E. The Lyric Art of Pierre Perrin, Founder of French Opera. Henryville, USA: Institute of Mediaeval Music, 1986.

_ “'Dealing in Shepherds”: The Pastoral Ploy in Nascent French Opera’. In

G. Cowart (ed.). French Musical Thought 1600-1800. London: U.M.I

Research Press, 1989, pp.53-80.

Ayer, A.J. Voltaire. New York: Random House, 1986.

Bacilly, Benigne de; Austin B. Caswell (ed., trans.). A commentary upon the art of proper singing. Brooklyn, N.Y.: Institute of Mediaeval Music, 1968.

Baille, Charles. Le cardinal de Rohan-Chabot : archeveque de Besancon (17881833): un prelat d'ancien regime au XIXe siecle, sa famille et son groupe. Paris: Perrin, 1904.

Bély, Lucien. Dictionnaire de l'Ancien Regime : royaume de France: XVIeXVIIIe siecle. Paris: Presses universitaires de France, 1996.

Bluche, François. Dictionnaire du grand siècle. Paris: Fayard, 1990.

Boffrand, Germain; Caroline van Eck (ed.). Book of Architecture. England: Ashgate, 2002.

Boisgelou [Paul-Louis Roualle de]. Table biographique des auteurs et compositeurs de musique dont les ouvrages sont à la Bibl[iothèque] nationale. Ms. Autogr., ca. 1800.

Boulton, Jonathon D.; William Kibler (eds). Medieval France: An Encyclopedia. New York: Garland Pub., 1995. 
Bousset, René Drouard de. Recueil d'airs nouveaus sérieux et à boire I. Paris: Boivin, Le Clerc, 1731.

Brossard, Yolande de. 'Musiciens de Paris 1535-1792 : actes d'etat civil d'apres le fichier Laborde de la Bibliotheque nationale’. Paris: Picard, 1965.

Brown, Marshall. 'Passion and Love: Anacreontic Song and the Roots of Romantic Lyric’. English Literary History. Vol. 66, no. 2, 1999, pp.374404.

Buelow, George J. A History of Baroque Music. USA: Indiana University Press, 2004.

Caldwell, John. Editing Early Music. Oxford: Clarendon Press, 1985.

Centre historique des Archives nationales, 'Les hôtels de Soubise et de Rohan au cœur du Marais. Un site d'exception chargé d’histoire...' available from www.archivesnationales.culture.gouv.fr/chan/chan/musee/action_culturelle /docs/Historique_Hotels.pdf.

Cessac, Catherine. Elisabeth Jacquet de la Guerre: Une femme compositeur sous le règne de Louis XIV. Arles: Actes sud, 1995.

Citron, Marcia J. Gender and the Musical Canon. Cambridge: Cambridge University Press, 1993.

Cohen, Albert. 'L'Etat de la France: One Hundred Years of Music at the French Court'. Notes, Vol. 48, no. 3, March 1992, pp. 767-805.

Collins French Dictionary \& Grammar. New York: HarperCollins Publishers, 2007.

Cotgrave, Randle. A Dictionarie of the French and English Toungues. London: Aadam Islip, 1611, available from www.pbm.com/ lindahl/cotgrave/.

Cowart, Georgia. The Origins of Modern Musical Criticism: French and Italian Music 1600-1750. Ann Arbor, Mich.: UMI Research Press, 1981.

Cusick, Suzanne G. 'Gender, Musicology, and Feminism'. Nicholas Cook and Mark Everist (eds). Rethinking Music. Oxford: Oxford University Press, 1999.

Cyr, Mary. 'Eighteenth-century French and Italian singing: Rameau’s writing for the voice'. Music \& letters, Vol. 61, no. 3/4, Jul-Oct 1980, pp. 318-337. Elisabeth-Claude Jacquet de La Guerre: The Collected Works. New York: The Broude Trust, 2005.

Debure, Guillaume and Joseph Basile Bernard van Praet. Catalogue des Livres 
de la Bibliothéque de feu M. le duc de la Vallière. Paris, CL. J. Bap. Bauche, 1760.

Devriès, Anik. Édition et commerce de la musique gravée a Paris dans la première moitié du XVIII siècle: Les Boivin, Les Leclerc. Geneve: Minkoff, 1976.

Eastwood, Tony. 'The French Air in the 18th Century: A neglected area'. Studies in Music, [Western Australia], Vol. 18, 1984, pp.84-107.

Ecorcheville, Jules. Vingt suites d'orchestre du XVIIe siècle français. New York: Broude, 1970.

Fuller, David. 'The Performer as Composer'. Performance Practice Music After 1600. Howard Mayer Brown and Stanley Sadie (eds.). Basingstoke, The Macmillan Press, 1989, pp.117-146.

Garden, Greer. 'The Airs of Jean-Baptiste de Bousset: The First Decade' (Seventh International Biennial Conference on Baroque Music, University of Birmingham, 4-7 July 1996).

'Songs by a child prodigy: the Airs srieux à deux (1691) . by Mademoiselle de Menetou' (Tenth International Biennial Conference on Baroque Music, University of La Rioja, 17-21 July 2002).

‘Variations d'un style reçu: Les airs de Desmarest publiés dans le Recueil d'airs sérieux et à boire de Ballard'. Henry Desmarest (1661-1741) Exils d'un musicien dans l'Europe du Grand Siècle. Mardaga: 2005, pp.355-372. Glickman, Sylvia; Martha Furmen Schleifer (eds). From Convent to Concert Hall: a guide to Women Composers. London: Greenwood Press, 2003.

Godtschalk, Ondine. Love's Desires and the Pleasures of Bacchus: The Airs of Jean Sicard (fl. 1666-1683). M.Mus. diss, Victoria University of Wellington, 1999.

Goldsmith, Elizabeth C.; Dena Goodman (eds.). Going Public: Women and Publishing in Early Modern France. Ithaca: Cornell University Press, 1995.

Goodman, Dena. The Republic of Letters: A Cultural History of the French Enlightenment. Ithica: Cornell University Press, 1994.

Gordon-Seifert, Catherine E. and Laury Gutiérrez. The Pleasures of Love and Libation: Airs by Julie Pinel and other Parisian women. Directed by Laury Gutiérrez. La Donna Musicale - LA 07103: Boston, 2007. 
Gordon-Seifert, Catherine E. Musical Voices of Early Modern Women. Aldershot Hants, England; Burlington, VT: Ashgate, 2005.

'La réplique galante: Sébastien de Brossard’s airs as conversation'.

Sébastien Brossard, Musicien. Jean Duron (ed.). Paris: Centre de Musique

Baroque de Versailles, Editions Klincksieck, 1998.

Gutwirth, Madelyn. Madame de Staël, Novelist: The Emergence of the Artist as Woman. Urbana: University of Illinois Press, 1978.

Harris, Ellen T. 'Voices’. Performance Practice Music After 1600. Howard Mayer Brown and Stanley Sadie (eds.). Basingstoke, The Macmillan Press, 1989, pp.97-116.

Heartz, Daniel. Music in European Capitals: the Galant Style, 1720-1780. New York: W.W. Norton, 2003.

Hehr, Elizabeth. 'How the French viewed the differences between French and Italian singing styles of the $18^{\text {th }}$ century'. International Review of the Aesthetics and Sociology of Music, Vol. 16, no. 1, June 1985, pp.73-85.

Hill, John Walter. Baroque Music. New York: W.W. Norton, 2005.

Isherwood, Robert M. Music in the service of the King: France in the seventeenth century. N.Y. Ithaca: Cornell University Press, 1973.

Jackson, Barbara Garvey. Say can you deny me: a guide to surviving music by women from the $16^{\text {th }}$ through to the $18^{\text {th }}$ centuries. Fayetteville, AR: University of Arkansas Press, 1994.

Jacobs, Eva (ed.). Woman and society in eighteenth-century France : essays in honour of John Stephenson Spink. London: The Athlone Press, 1979.

Jones, Colin. The Great Nation. London: Penguin Books, 2003.

Jones, Michael. Ducal Brittany 1364-1399. London: Oxford U.P., 1970.

Kale, Steven. French salons : high society and political sociability from the Old Regime to the Revolution of 1848. Baltimore: The Johns Hopkins University Press, 2004.

Kimball, Fiske. The Creation of the Rococo. Philadelphia Museum of Art, 1943.

Koskoff, Ellen. 'What Do We Want to Teach When We Teach Music?'

Nicholas Cook; Mark Everist (eds). Rethinking Music. Oxford: Oxford University Press, 1999.

Launay, Denise. 'Lebeau, Élisabeth - Un collaborateur bénévole de la 
Bibliothèque nationale à la fin du XVIII siècle, Paul-Louis Roualle de Boisgelou, 1734-1806'. Bulletin d'Information de l A. B. F.. 27 Nov. 1958.

Le Maire, Louis; Laurent Gervais, Nicolas Racot de Grandval. Cantatas and cantatilles. New York: Garland, 1991.

Lecerf de la Viéville, seigneur de Fréneuse, Jean Laurent. Comparison de la musique italienne et de la musique française. Genève: Minkoff Reprint, 1972.

Lesure, François and Frayda B. Lindemann. 'The Music Department of the Bibliothèque Nationale, Paris’. Notes. Vol. 35, no. 2, Dec. 1978, pp.251268.

Lougee, Carolyn C. Le Paradis des Femmes. Princeton, N.J.: Princeton University Press, 1976.

Lough, John. An Introduction to Seventeenth-Century France. London: Longmans,1957.

—An Introduction to Eighteenth-Century France. London: Longmans, 1960.

Martin, Georges. Histoire et Généalogie de la Maison de Rohan. Lyon: G. Martin, 1998.

Massip, Catherine. 'Airs français et italiens dans l'édition française 1643-1710'. Revue de musicologie, Vol. 77, no. 2, 1991, pp. 179-185.

Melzer, Sara E.; Kathryn Norberg (eds.). From the royal to the republican body: incorporating the political in seventeenth-and eighteenth-century France. Berkeley, Calif.: University of California Press, 1998.

Moriarty, Michael. Taste and Ideology in Seventeenth-Century France. Cambridge: Cambridge University Press, 1988.

Mourgues, Odette de. Metaphysical Baroque \& Précieux Poetry. Oxford: Clarendon Press, 1953.

Neuls-Bates, Carol. Women in Music. Boston: Northeastern University Press, 1996.

Neumann, Frederick. Essays in Performance Practice. Ann Arbor, Mich.: UMI Research Press, 1982.

Ornamentation in Baroque and Post-Baroque Music: with

Special Emphasis on J. S. Bach. Princeton: Princeton University Press, 1978. 
Performance Practices of the Seventeenth and Eighteenth

centuries. New York: Schirmer Books, 1993.

Niklaus, Robert. The Eighteenth Century, 1715-1789. London: Benn; New York: Barnes \& Noble, 1970.

Oxford English Dictionary Online available from http://dictionary.oed.com.helicon.vuw.ac.nz/.

Pekacz, Jolanta T. Conservative Tradition in Pre-Revolutionary France: Parisian Salon Women. New York: Peter Lang, 1999.

-The Formative Effect of Honnêtté on Parisian Salons. New York: Peter Lang, 1999.

-The Salonniere and the Philosophes in Old Régime France: The Authority of Aesthetic Judgement'. Journal of the History of Ideas. Vol. 60, no. 2, April 1999, pp.277-297.

Pendle, Karin (ed.). Women \& Music: a history. Bloomington: Indiana University Press, 2001.

Plessix Gray, Francine du. At Home with the Marquis de Sade. New York: Simon \& Schuster, 1998.

Rempel, Ursula M. 'Women and Music: Ornament of the Profession?' Samia I. Spencer (ed.). French Women and the Age of Enlightenment. Bloomington: Indiana University Press, 1984, pp.170-180.

Riley, James C. The Seven Years War and the Old Regime in France. Princeton, N.J.: Princeton University Press, 1986.

Rollin, Monique; Jean-Michel Vaccaro. Oeuvres de Pinel: Edition et transcription. Paris: CNRS, 1982.

Charles-M. de la Roncière. 'Département des manuscrits, Bibliothèque nationale.' Catalogue général des manuscrits français. France: E. Leroux, 1902.

Rosenmeyer, Patricia A. The Poetics of Imitation. Cambridge; New York: Cambridge University Press, 1992.

Sadie, Julie Anne. 'Musiciennes of the Ancien Régime', Jane Bowers; Judith Tick (eds.). Women Making Music. Urbana : University of Illinois Press, 1986.

Sadie, Stanley; J. Tyrrell (eds.). The New Grove Dictionary of Music and Musicians. London: Macmillan, 2001. 
Solnon, Jean-François. 'Princes'. François Bluche (ed.). Dictionnaire du grand siècle. Paris: Fayard, 1990.

Smith, Felicity. 'René Drouard de Bousset'. MMus thesis, Victoria University of Wellington, 2008.

Strauss Sotiropoulos, Carol. Early Feminists and the Education Debates. USA:

Fairleigh Dickinson University Press, 2007.

Suberville, Jean. Histoire et théorie de la versification française. Paris: Les Editions De 'L'Ecole', 1946.

Tillet, Titon du. Le Parnasse francois. Paris: Gallimard, 1991.

- Vies des musiciens et autres joueurs d'instruments du règne de Louis le Grand. Paris: Gallimard, 1991.

Tunley, David (ed.). Cantatas and Cantatilles by Louis Le Maire. New York:

Garland, 1991.

-The Eighteenth Century French Cantata. London: Dennis Dobson, 1974.

Van Orden, Kate. Music, discipline, and arms in early modern France. Chicago: University of Chicago Press, 2005.

Velde, François R. 'The Rank/Title of Prince in France'. Heraldica, available from http://www.heraldica.org/topics/france/frprince.htm.

Vollen, Gene E. The French cantata : a survey and thematic catalog. Ann Arbor, Mich.: UMI Research Press, 1982.

Voltaire. Voltaire's Correspondence. Theodore Besterman (ed.). Geneva: Institut et Musee Voltaire, 1953-1965.

Weber, W. 'La musique ancienne in the waning of the ancien régime'. Journal of Modern History. Vol. 56, no. 1, 1984, pp.58-88.

Webster, James. The Triumph of Variability: Haydn's Articulation Markings in the Autograph of Sonata No.49 in E-flat. New York: Oxford University Press, 1998.

Yarrow, P.J. A Literary History of France: The Seventeenth Century 1600-1715. London, Benn; New York, Barnes \& Noble, 1967.

Yelloly, Margaret, ‘The ingenious Miss Turner'. Early Music, Vol. 33, no. 1, 2005, pp.65-80. 


\section{VOLUME 2}

\section{Contents}

Julie Pinel, Nouveau recueil d'airs sérieux et à boire à une et deux voix, de Brunettes à 2 dessus, scène pastorale, et cantatille avec accompagnement (1737).

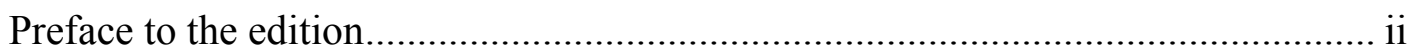

Facsimile of the title page from the 1737 edition ................................................. iii

Facsimile of the first page of the cantatille in the 1737 edition............................. iv

Partial translation of Pinel's 1736 Privilège Général ............................................. v

Summary of Editorial Method ............................................................................ vi

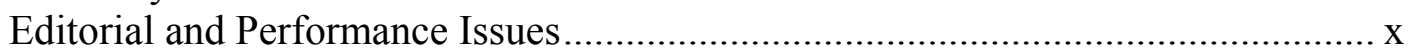

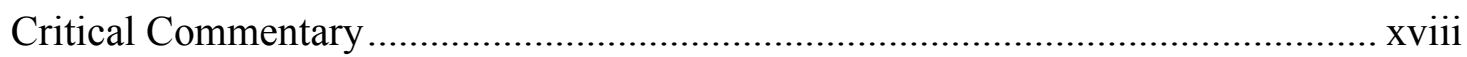

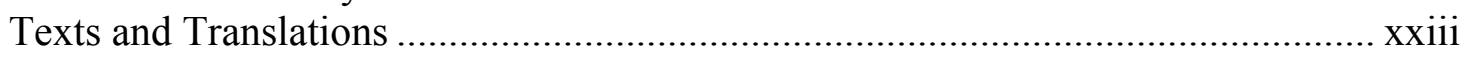

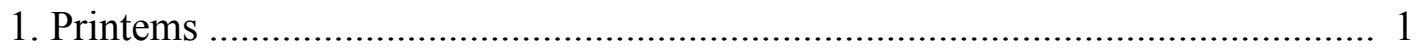

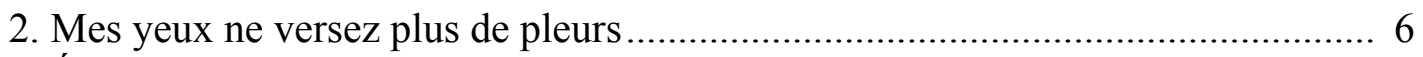

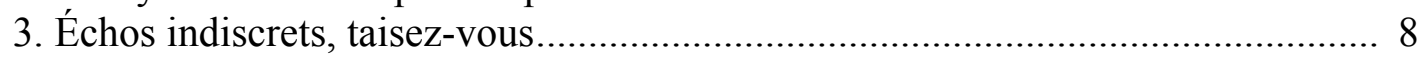

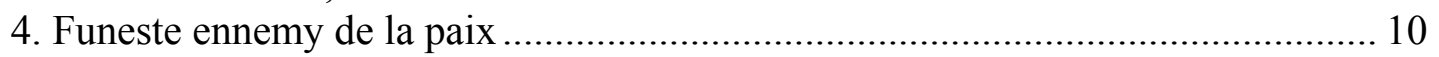

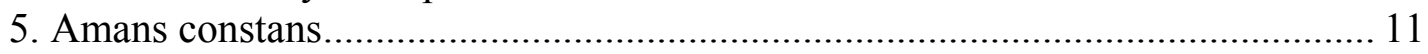

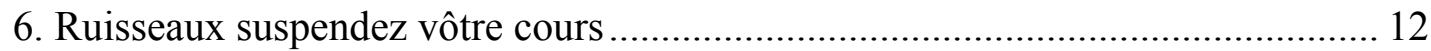

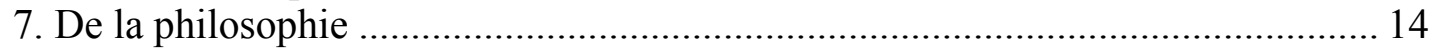

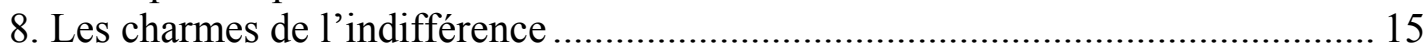

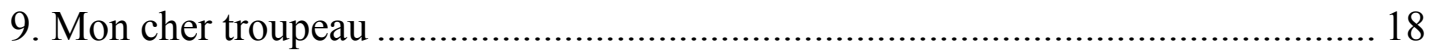

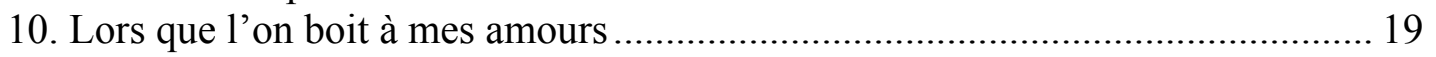

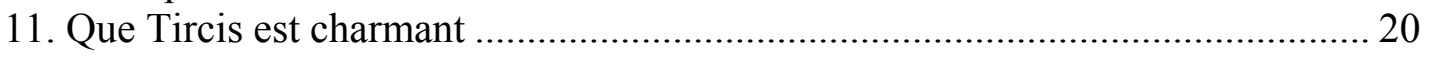

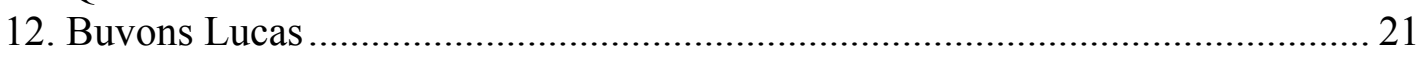

13. Apres m'avoir formé plus aimables chaines .................................................... 23

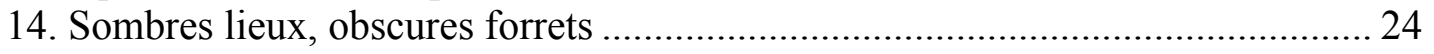

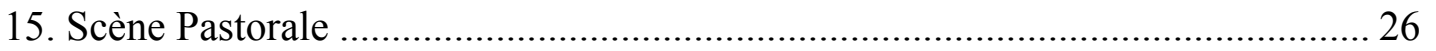

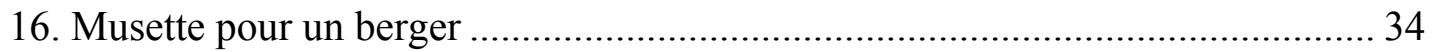

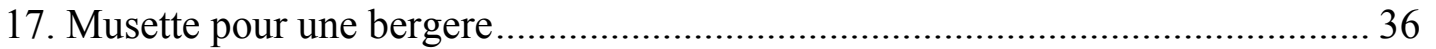

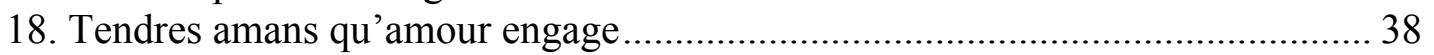

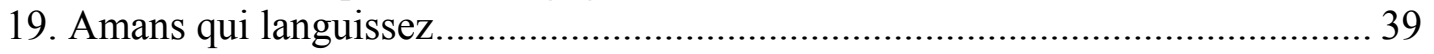

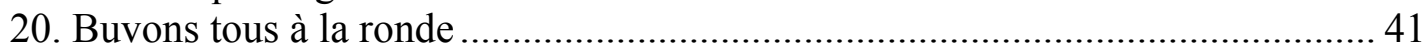

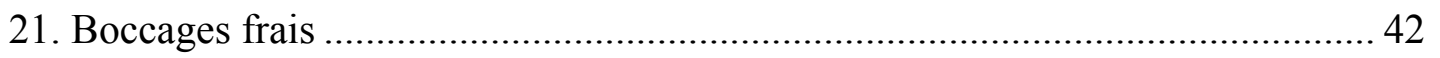

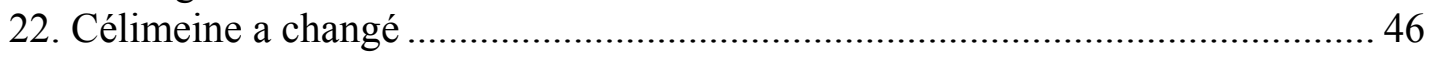

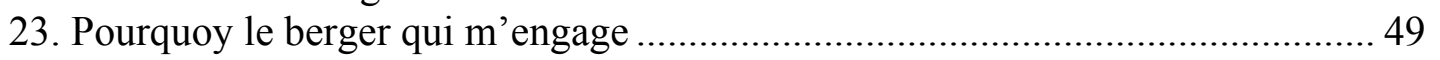

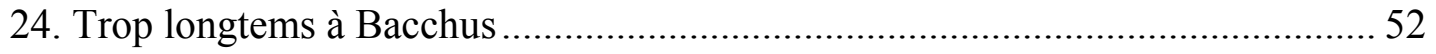

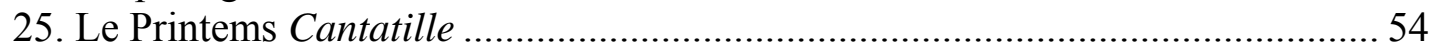

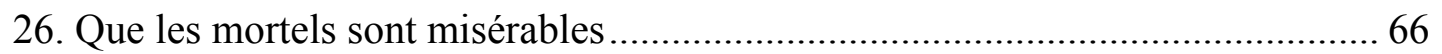

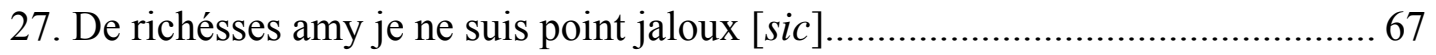

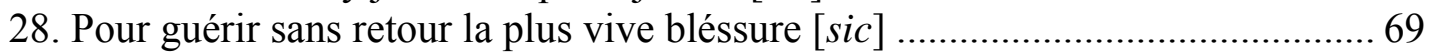

29. Dieu du vin quelle est donc ta fatalle puissance ............................................. 70

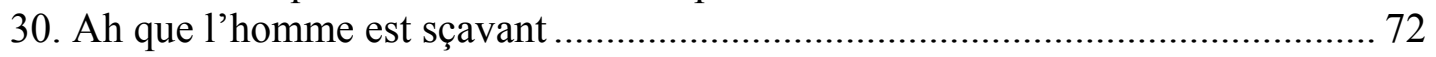

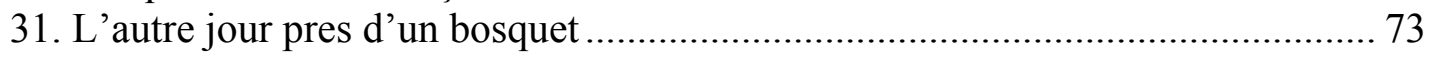




\section{Preface to the Edition}

This edition of Julie Pinel's Nouveau recueil d'airs sérieux et à boire à une et deux voix, de Brunettes à 2 dessus, scène pastorale, et cantatille avec accompagnement, F-Pn / Vm7 629 (Paris: Veuve Boivin, Le Clerc, 1737), represents the entirety of her extant music, as far as we know. The collection comprises sixteen airs sérieux and thirteen airs à boire, and they display the variation of Pinel's compositional style within a range of air types. Also included are a Scène pastorale and a cantatille which demonstrate Pinel's ability to compose for larger genres. The French text which accompanies each work can be found before the music of this edition on page xxii, alongside its English translations. ${ }^{1}$

\footnotetext{
${ }^{1}$ A handful of these translations come from the liner notes for La Donna Musicale, The Pleasures of Love and Libation: Airs by Julie Pinel and other Parisian women, directed by Laury Gutiérrez (La Donna Musicale - LA 07103: Boston, 2007). They are as follows: Jefferson Kline: 'Printems'; Margaret Hunter: 'Echos indiscrets, taisez vous', 'Cantatille: Le Printems'; Catherine Gordon-Seifert: 'Scène Pastorale','Boccages frais', 'Pourquoy le berger qui m'engage'. Thanks are due to Dr. Greer Garden who assisted me with finer points of translation.
} 
Plate 1. Title page of Pinel's 1737 publication, Nouveau recueil d'airs sérieux et à boire.

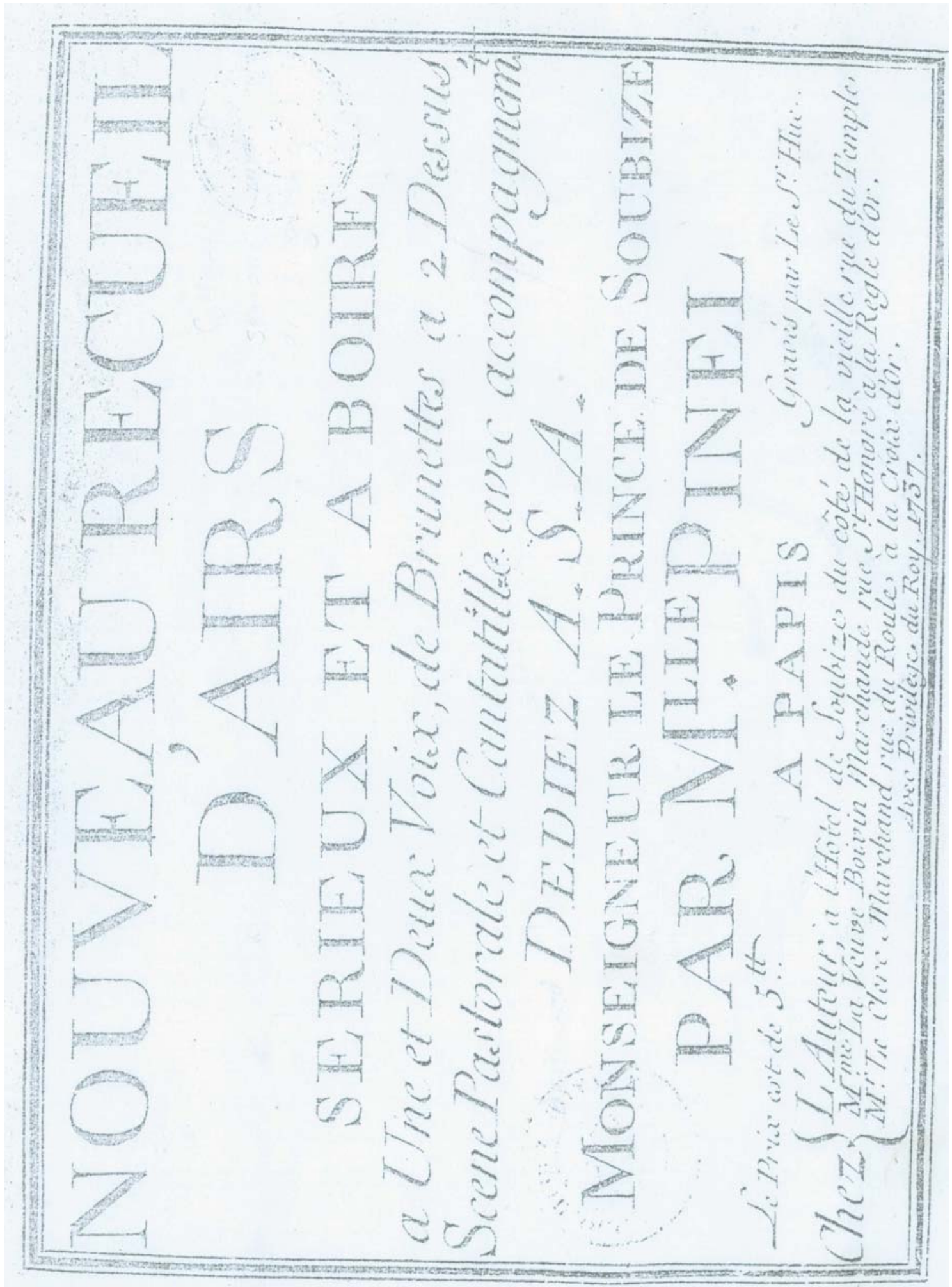


Plate 2. First page of the cantatille 'Le Printems' in Pinel's 1737 publication, Nouveau recueil d'airs sérieux et à boire.

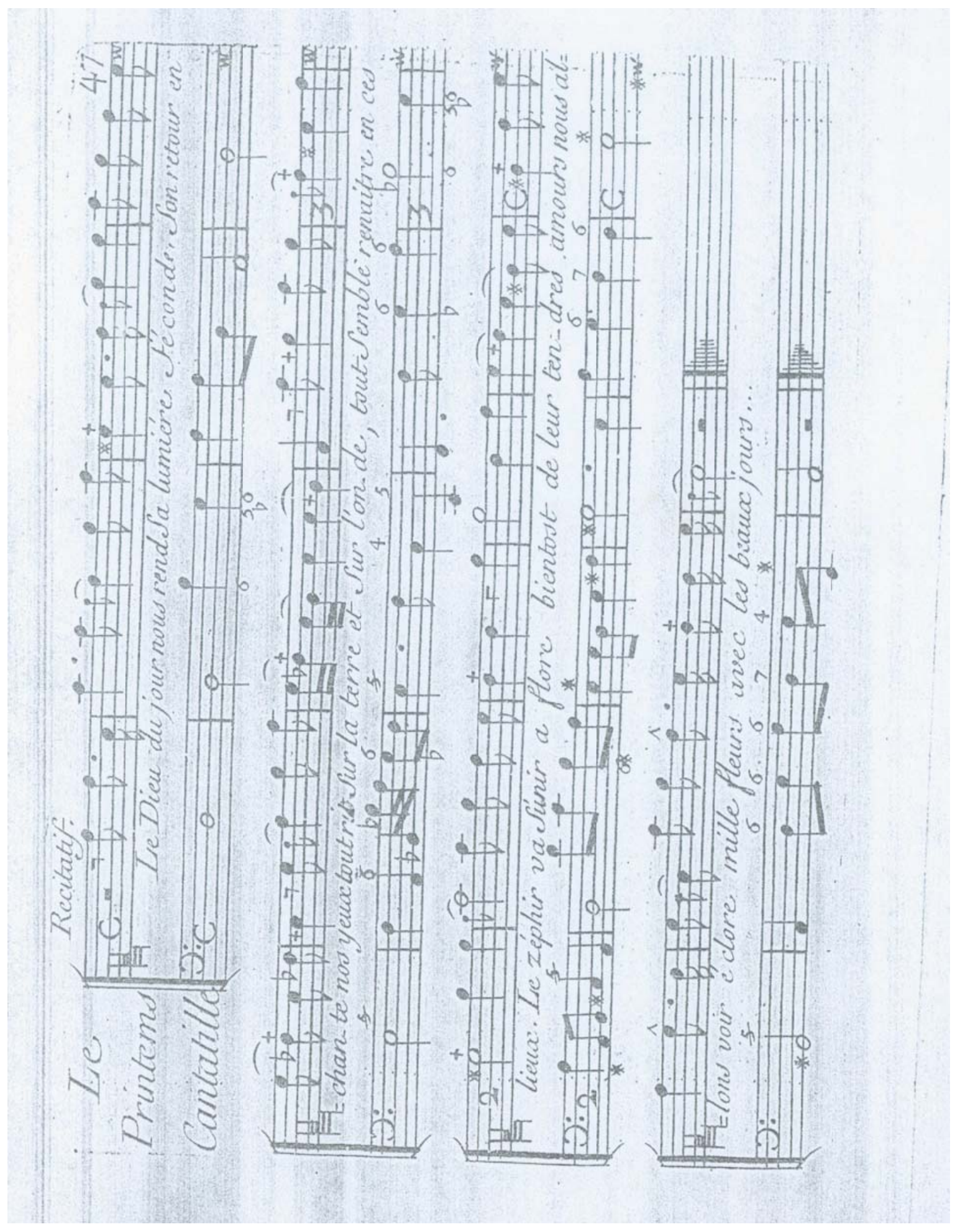




\section{Partial translation of Pinel's 1736 Privilège Général}

Privelège Générale of 1736 (Partial translation)

[...] notre chere et bien amée, [sic] Julie Pinel nous a fait Remontrer, qu'elle souhaitteroit, faire imprimer et graver, et donner au Public, - plusieurs Recueils d'Airs, de Cantates, et autres ouvrages de Musique, tant vocale, qu'instrumentale de sa Composition, S'il nous plaisait luy accorder nos lettres de privilege, Sur ce necessaires, A ces causes voulant traitter favorablement ta ditte exposante, Nous luy avons permis et permettons par ces presentes, de faire imprimer et graver, par tels imprimeurs et graveurs qu'elle voudra choisir les dits Recueils d'airs, de Cantates, et autres ouvrages de Musique tant vocale qu'instrumentale de sa Composition, en tels volumes forme marge Caractere, conjointement ou separement, et autant de fois que bon luy semblera, et de les vendre, faire vendre et débiter par tout notre Royaume pendant le tems de huit années Consecutives a compter du jour de la datte des dites presentes, [...] Donné a Paris le 23 jour Novembre Lan de grace, mil Sept cent trente six, et de notre regne le vingt deuxieme,

Par le Roy en son conseil,

[...] Our dear and beloved Julie Pinel is again showing us, has made known to us that she wishes to have printed and engraved, and offered to the public several collections of airs, cantatas and other pieces of vocal and instrumental music of her composition, if it pleased us to grant her our letters of privilege, necessary for this purpose, For these reasons, wishing to treat the exhibitor favourably, we have permitted her and do permit her, by this present document to have printed and engravers of her choice the said collections of airs, cantatas and other pieces of vocal and instrumental music of her composition, in what ever volume, form, character, conjointly, or separately, and as often as seems good to her, and to sell them and have them sold throughout our kingdom during a period of eight consecutive years from the date of this document [...] Given at Paris the 23rd day of the month of November, the year of grace 1736, and of our reign the $22^{\text {nd }}$, by the King in his Council [... 


\section{Summary of Editorial Method}

\section{GENERAL EDITORIAL NOTES}

Bar numbers have been added to each air, and are counted from the first complete bar. Any split bars are counted as one bar. The ornamentation of the original source has been retained.

The instrumental specifications in the original source have been retained. In most of the airs, the editor has added 'voix' and 'basse continue' in square brackets to the left of the appropriate staves for consistency and clarity. All parts in the original source have a separate staff, with the exception of the Scène Pastorale, in which the characters Iphis and Daphné share one staff up until the final duo. In this edition, these parts have been separated into individual staves, with the empty staves being suppressed at the beginning and end of the section.

\section{CLEFS}

In this edition, the original $\mathrm{C} 1$ and $\mathrm{C} 4$ clefs have been replaced with the treble clef and the transposing treble clef respectively. The basse-continue part in the cantatille, 'Le Printems', alternates between the bass clef $\left(\mathrm{F}_{4}\right)$, alto clef $\left(\mathrm{C}^{3}\right)$ and tenor clef $\left(\mathrm{C}_{4}\right)$, which have not been altered. Prefatory staves precede the editorial clefs in the appropriate airs to indicate the original clefs used by Pinel.

\section{BEAMING AND SLURS}

In the original source, beaming is only used in the vocal parts to join the notes that are sung to a single syllable. The original beaming in all parts has been retained. All ties and slurs in the source are reproduced in this edition. Ties have been supplied for notes replacing dots after bar-lines.

\section{REPEAT SIGNS}

Most of Pinel's airs include the double dotted barline ': || ' which by this time functioned as a repeat sign. In most airs, a first and second time ending is also included, both at the repeat of the first half, and at the end, which suggest that 
they are normally to be repeated. ${ }^{2}$ These have been retained and modernised. However, there is some uncertainty in particular airs as to whether the 'repeat' sign is sufficient information for a repeat, given that they were included in every air regardless of whether there were first and second time endings or not. 'Les charmes de l'indifférence' is one example of an air which includes a repeat sign at the end without a first and second time ending. One can assume that this particular air is unlikely to be repeated. All repeat signs have been retained in this edition so that it is the performer's decision as to whether or not a section is to be repeated.

\section{TIME SIGNATURES}

The original time signatures have been retained. While 3/2 appears in a number of the airs, most occurrences of triple time signatures omit the denominator and instead give the indication, 3. In this edition, a denominator has been supplied editorially in square brackets. No suggestion has been provided as to the transition between different time signatures since there is no evidence that proportional relationships between them were intended. In 'Printems' the time signature of 2 has been replaced with $C$ to agree with the rhythm and beaming of the air and this is noted in the critical commentary.

\section{KEY SIGNATURES AND ACCIDENTALS}

The minor key signatures in the original source are one flat short in the keys of D minor, $\mathrm{G}$ minor and $\mathrm{C}$ minor. The original key signatures have been retained because the raised sixth is frequently found within the music, suggesting the Dorian or transposed Dorian mode.

In keeping with modern practice, accidentals apply throughout the bar. Those that are repeated within a bar have been suppressed without comment. Flat signs which cancel raised notes have been replaced with natural signs, as have any sharp signs that raise flattened notes.

\footnotetext{
${ }^{2}$ In addition, the inclusion of guidons (directs) in most airs confirms that they are to be repeated.
} 


\section{FIGURED BASS}

Pinel's bass figures are mostly printed below the bass staff, but some are placed above, probably due to spacing reasons rather than for musical reasons. Any bass figures which appear above the continuo line have been placed below the staff in this edition.

There are instances where there is a sharp in the figuring to signify an augmented interval, even though the sharp is included in the key signature and could be interpreted as a double sharp. For example, in bar 24 of 'Musette pour un berger' the augmented fourth on the first beat does not require a sharp sign because it is already in the key signature and the figuring implies a B sharp, which creates ambiguity for the basso continuo player. These figures have been retained on the premise that the basso continuo player will have the knowledge and skill to realise these chords correctly. Where accidentals continue through the following figure in the souce, the accidental has been reproduced in square brackets.

Any accidentals in the figuring that are already in the key signature have been suppressed without comment. Found throughout Pinel's collection are the figures 56 and ${ }^{56}$. These figurings are unusual because they do not signify separate chords, particularly because in many cases they are placed on small-value notes which do not allow for that kind of realisation. Instead, it seems to be that Pinel intended the figures $\stackrel{6}{5}$ and $\stackrel{6}{5}$ r respectively, and due to spacing constraints in the original source, the engraver has obviously produced the figures consistently throughout the collection in the form described above. In each instance where these figures occur, they have been replaced tacitly with the modernised figuring.

\section{RHYTHM}

Pinel also employs a lot of dotted notes within her collection which are often followed by a run or ornamental flourish. In this edition, these parts have been left as they are in the original even though the given notes may not make up a complete bar or conversely, may be more than a bar long. 
White-note notation in the air à boire 'Amans qui languissez' has been changed to its black-note equivalent. Triplets and tuplets have been left unmarked because they are often rhythmically inconsistent. Where the value of a dotted note extends over a bar line, this has been resolved with a tied note which equals the value of the dot, and is recorded in the critical commentary. An example of this can be found in 'Echos indiscrets, taisez vous', bars 10 to 11 . The rhythmic value of grace-note ornaments is identical to the source.

\section{SPELLING AND PUNCTUATION}

The original spelling has been retained unless the meaning of a word is unclear, in which case any changes are noted in the critical commentary. Abbreviated words have been realised. In situations where no accents are given but pronunciation requires them, or the meaning of the word would otherwise be unclear, these have been supplied. Where the meaning is clear, the grave accent has been retained, as an indication of historic pronunciation (eg. régne). ${ }^{3}$

Capitalisation has been added to the beginning of each new line for clarity and consistency. Any character names have also been capitalised if they are not in the original. In general, the punctuation of the original is good. However, editorial additions have been made where necessary, again for clarity and consistency. Apostrophes have been added in between an article and a noun which run together in the text i.e. 'Lingrat' becomes 'L'ingrat' in 'Ruisseaux, suspendez vôtre cours'. Punctuation has been added to make sense and the occasional misplaced comma has been emended. These changes have not been noted in the critical commentary.

\footnotetext{
${ }^{3}$ The reader is referred to Mary Cyr's advice on pronunciation. Elisabeth-Claude Jacquet de la Guerre: The Collected Works Vol.3 (New York: The Broude Trust, 2005), pp.xxviii-xxx.
} 


\section{Editorial and Performance Issues}

The interpretation of Baroque music centres around three ideals: diversity, ornamentation and rhythm. These differ in terms of style, genre and country. Many scores from early eighteenth century France are void of indications for instrumentation, tempi, dynamics and other instructions. We have only this one source by Pinel, and while it does include tempo markings, expression markings, and ornamentation, there are still ambiguities surrounding the performance of this music. Thus we must turn to other sources to determine what practices were in use during Pinel's day, and to decide whether those conventions may apply to her music as well. Baroque singers and instrumentalists were required to exercise some degree of interpretation and/or improvisation in order to produce a rounded performance. ${ }^{4}$ The thoroughbass player needed to do this with the harmony, just as the soloist was expected to provide correct ornaments for the melody; performers were trained to do so. Pinel's collection also reflects the flexibility in performance during this period required to accommodate things such as the availability of performers and the size of the venue. ${ }^{5}$

\section{INSTRUMENTATION}

Voices: All parts for bass voice and the air for basse-taille, 'De la philosophie', are notated in the bass clef $\left(\mathrm{F}_{4}\right)$. All soprano parts are notated in either the treble clef $\left(\mathrm{G}^{2}\right)$ or in the soprano clef $\left(\mathrm{C}^{1}\right)$, and these clefs correspond to the soprano (dessus) and mezzo-soprano (bas dessus). ${ }^{6}$ It was common for parts notated in the treble clef to be transposed down an octave, allowing men to perform them. This is a possibility for the performance of some of Pinel's airs, particularly because some of her texts imply that a man is the protagonist: see 'Musette pour un berger', 'Lors que l'on boit a mes amours', and 'Buvons Lucas'. A modern example of this practice is heard in the recent recording of a selection of Julie Pinel's music by the musical group 'La Donna Musicale'? They utilised

\footnotetext{
${ }^{4}$ David Fuller, Howard Mayer Brown \& Stanley Sadie (eds.), 'The Performer as Composer', Performance Practice Music After 1600 (UK, The Macmillan Press, 1989), p. 117.

${ }^{5}$ Cyr, 2005, p.xxii.

${ }^{6} \mathrm{Cyr}, 2005$, p.xxviii.

${ }^{7}$ La Donna Musicale is an organisation dedicated to the research and the historical performance of Renaissance, Baroque, Classical, and Contemporary music by women composers. See their website at http://www.ladm.org/index.html.
} 
transposition to match their performers' needs and abilities, as well as to create diversity in their recordings. For example, in their recording of the air sérieux, 'Printems', a tenor sings the vocal part which is written for soprano. Similarly, in 'Boccages frais', a brunette for two soprano voices, the air has been transposed down a tone, showing how eighteenth-century airs were commonly transposed to accommodate particular performers. ${ }^{8}$

The vocal style and practice of the Baroque era are similar to what we would want in modern times with regard to intonation, breathing technique, clear enunciation of words, and the proper expression of a text. Sudden changes in dynamics were discouraged because it was considered inconsistent, so crescendo and diminuendo were only practised on long-held notes. ${ }^{9}$

Obbligato instruments: There are two pieces in Pinel's collection that include parts for melodic instruments: Flûtes are required for the air sérieux, 'Printems', and the final air in the cantatille, 'Le Printems', specifies flutes ou violons. When an instrument is given a plural indication, as is the case with these compositions, one can assume that there is to be a minimum of two or three players. ${ }^{10}$ However, due to the nature of this music, which was often performed in more intimate settings, it is also acceptable for one player to perform the part.

Basse-continue: Typically, the forces of the basse-continue are not indicated. The vast majority of Pinel's basse continue parts are notated in the bass clef ( $\left.\mathrm{F}_{4}\right)$, however there are instances of notation in the alto $\left(\mathrm{C}^{3}\right)$ and tenor $\left(\mathrm{C}_{4}\right)$ clefs as well. ${ }^{11}$ Such parts were normally performed by a harmonising instrument such as the harpsichord, whose function was to realise the figured bass line. In addition, it was typical practice for a melodic instrument to play this part as well, in order to provide harmony and enhance the texture of the air. ${ }^{12}$ By Pinel's time, this

\footnotetext{
8 Tunley discusses transposing by changing clefs in The Eighteenth-Century French Cantata (London: Dennis Dobson, 1974), pp.197-8, cited in Cyr, 2005, p.xxviii.

${ }^{9}$ Ellen T. Harris, 'Voices', Performance Practice Music After 1600 (UK: The Macmillan Press, 1989), p.103.

${ }^{10}$ Cyr, 2005, p.xxxi.

${ }^{11}$ See Pinel's cantatille, 'Printems'.

${ }^{12}$ Cyr, 2005, p.xxx. For further information, consult Julie Anne Sadie, The Bass Viol in French Baroque Chamber Music (Ann Arbor, Mich.: UMI Research Press, 1980).
} 
instrument was often a bass viol, rather than a theorbo or lute, which was usually employed in late seventeenth-century French music. ${ }^{13}$ In fact, the cello and bassoon were beginning to substitute for the viol in some performances during this period. ${ }^{14}$

\section{DYNAMICS}

There are very few instances of dynamic markings in Pinel's collection, however, those that are included warrant mention. The markings doux and fort appear in the instrumental parts of 'Printems', and in the final air of 'Le Printems'. It is most likely that these indications serve as a reminder to the performer not to overwhelm the vocal part, particularly if the instrumental line is being performed by more than one player.

\section{TEMPO AND EXPRESSIVE MARKINGS}

Ascertaining the tempo for an air can be problematic, particularly for those airs with numerous metre changes, common in French vocal music. Pinel's collection includes various metre signatures which pose some questions as to the way in which they should be interpreted. Fortunately, she included tempo and expressive markings in a large number of the airs in this collection, which aids the interpretative process.

For those airs without tempo markings, it is assumed that some indication of tempo may be gleaned from the metre signature itself. M. Dupont and Montéclair distinguished between $\mathbf{C}$ and $\mathbf{C}$, believing $\mathbf{C}$ to be indicative of a quick tempo (leger) in four beats (or in two), and believing that $\mathbf{C}$ was for a more moderate tempo in four beats (grave). ${ }^{15}$ Saint-Lambert suggested that 2 denoted a tempo twice as fast as $\mathbf{C}$; and that $\mathbf{3} / \mathbf{2}$ was to be interpreted as grave, with 3 being twice as fast again 'because the measure is only made up of three quarter notes...' 16

\footnotetext{
${ }^{13}$ Peter Williams, David Ledbetter, 'Continuo', Grove Music Online ed. L. Macy (Accessed 8 April 2008), http://www.grovemusic.com.

${ }^{14}$ Cyr, 2005, p.xxx.

${ }^{15}$ M. [first name unknown] Dupont, Principes de musique par demandes et par responses, nouvelle edition (Paris: J.-B. Christophe Ballard, 1719), pp.25-31. Michel Pignolet de Montéclair, Principes de musique (Paris: Veuve Boivin, 1736), section "mesure et mouvement", pp.116-118 as cited in Cyr, 2005, p.xxii.

${ }^{6}$ Saint-Lambert, pp.37 and 48-49.
} 
Likewise, Dupont and Montéclair reported that the time signature 3/2 indicated a slow tempo in three beats. ${ }^{17}$ Other duple metres were rare in early eighteenthcentury airs, and Dupont stated that the signatures 2/4 and 4/8 were suggestive of a quick tempo, and that 2/4 was faster than $2 .^{18}$

Pinel's time signatures are limited primarily to 3 , and 2. 3/2, C, $\mathbb{C}$ and 2/4 occur less frequently, and 9/8 only occurs in one air, 'Buvons tous a la ronde'. A number of Pinel's airs have transitions between duple and triple metres; however, many are accompanied by tempo indications. Still, there remains the issue of negotiating such changes smoothly. Saint-Lambert looked at the relationship between duple and triple time and came up with the theory that the beat should remain the same through the change i.e. a transition from $\mathbf{C}$ to $\mathbf{3}$ would have crotchet equalling crotchet. Of course, others interpreted metrical changes in a proportional manner. ${ }^{19}$

Both kinds of interpretation can be applied in Pinel's collection of airs. The air sérieux, 'Echos indiscrets, taisez vous' best suits a beat=beat approach with the metres 2 and 3/2 allowing for the prosody to flow. On the other hand, the air à boire, 'Celimeine a changé' has a variety of metrical signatures which require some tempo changes. The opening fifteen bars are without any tempo indication, and in bar 16 the music is marked lentement ${ }^{20}$ for the return to the opening metre: C. We can assume that this tempo indication can apply for bars 1 to 6 , which are also in $\mathbb{C}$. In bar 19 there is a further change of metre, this time to 2, and Pinel has provided the indication, gay. ${ }^{21}$ Given that they occur straight after each other, this transition confirms Saint-Lambert's argument about the difference in tempo between the time signatures $\mathbf{2} / \mathbf{2}$ and $\mathbf{C}$. Bar 24 sees a return to $\mathbb{C}$ with no tempo indication, and in bar 29 there is another marking, vif, which indicates a lively tempo similar to allegro and gay. Finally, in bar 32 there is a final change to the

\footnotetext{
${ }^{17}$ Dupont, 1719, p.26; Montéclair, 1736, p.117 cited in Cyr, 2005, p.xxiii.

${ }^{18}$ Dupont, 1719, pp.25-26; Montéclair, 1736, p.25.

${ }^{19}$ For an overview of metre in music during the early eighteenth century, refer to George Houle, Meter in Music, 1600-1800 (Indianapolis: Indiana University Press, 1987), p.20.

${ }^{20}$ Indicative of a slow tempo. David Fellows, 'Lento', Grove Music Online ed. L. Macy (Accessed 8 April 2008), http://www.grovemusic.com.

${ }^{21}$ Also spelled as gayement which is found in Pinel's collection, this marking suggests a happy and cheerful mood as much as it indicates a tempo similar to allegro. David Fallows, 'Gai', Grove Music Online ed. L. Macy (Accessed 8 April 2008), http://www.grovemusic.com.
} 
metre 3 which is accompanied by the term gay. This expressive indication belies Saint-Lambert's statement that $\mathbf{3}$ indicated a grave tempo.

Other instances of multiple metre changes are found in the récits de basse. While these also have clear tempo indications, the nature of these airs is freer, and the changes are more flexible. Interestingly, the récits de basse have the largest number of expressive indications of any air type found in this collection. Perhaps this is in compensation for the lack of basse-continue part in these airs and to accompany the metre changes, allowing smooth textual flow. Perhaps, too these drinking songs used to be sung in an impassioned way.

The tempo and expressive indications used by Pinel in this collection are varied and include the following: lentement, vif, gay, gayement, modrement, vivement, tendrement, gracieux, and doucement. It is unclear whether these terms signify tempo or mood. It is likely that they indicated both in some form. For example, the expression doucement, meaning both 'sweetly' and 'gently', 22 might indicate a slow or moderate tempo, as much as it could signify a refined character.

\section{ORNAMENTATION}

Pinel's compositions include various ornaments, some of which occur very frequently. The ornament most commonly found throughout Pinel's collection is the tremblement, or trill, which is always indicated by the symbol + except for 'Les charmes de l'indifférence', in which we find the trill symbol in bars 19 and 69. It is unclear what the latter symbol indicates in this air, especially given that it is used in conjunction with +. Montéclair's Principes de musique (1736) provides a detailed overview of different French ornaments, and sorts the trill into various groupings, describing + as a tremblement subit (short trill) which is sung or played immediately, typically beginning on the upper auxiliary. ${ }^{23}$ Given that + is used on both short and long notes, the number and frequency of

\footnotetext{
${ }^{22}$ Sir Jack Westrup, F.LL. Harrison, Conrad Wilson, Dictionary of Music (London; Glasgow: Collins, 1988), p.140.

${ }^{23}$ Montéclair, 1736. Translated by J. Anthony \& D. Akmajaian in the preface to their edition of Montéclair's Cantatas Book III, A-R Edition, Madison, Wisconsin, 1978 (Recent Researches in the Muisc of the Baroque Era, Vols. XXIX-XX), pp.xv-xvi.
} 
oscillations depends on the performer's ability, as well as the mood of the music and text. ${ }^{24}$

The other ornament found throughout this collection is the petite note, a small note, which precedes or follows a note of the melody. ${ }^{25}$ Bénigne de Bacilly's 1668 treatise Rémarques curieuses sur l'art de bien chanter explains that these ornaments can function in several ways when placed in different circumstances. ${ }^{26}$ The petite note can function as a port de voix, an appoggiatura from below; as a coulé, a passing appoggiatura between thirds in the melody; ${ }^{27}$ or as a chûte, or descending anticipation. ${ }^{28}$ The majority of these notes are small quaver notes which are performed on the beat, and depending on the music and/or performer, they may take up to half the value of the main note to which they are attached. Another ornament which appears often is $\wedge$. This is most likely a symbol for a port de voix or coule $e^{29}$ depending on where it is placed in the music. It may also signify a trill of some sort, which is how some of these ornaments are performed by 'La Donna Musicale' in their recording of 'Le Printems'.

The accent ' is found in bars 28 and 31 of the air sérieux, 'Ruisseaux suspendez vôtre cours'. This symbol usually signifies staccato articulation or a dynamic accent. ${ }^{30}$ Both occurrences of this accent are used to express despair, on the words 'triste' and 'hé', which is characteristic. This ornament is not found in tender airs expressing happiness and gaiety.

The charm of the airs was in their performance and the aspect of improvisation in their performances. While Pinel's collection includes some ornamentation, it must be kept in mind that the wonderful dimension of the air was the excitement of hearing how great singers could embellish the music. There is certainly scope

\footnotetext{
${ }^{24}$ Montéclair, 1736, pp.xv-xvi.

${ }^{25} \mathrm{Cyr}, 2005$, p.xxvi.

${ }^{26}$ See Bénigne de Bacilly, translated and edited by Austin B. Caswell, A commentary upon the art of proper singing [by] Bénigne de Bacilly (Brooklyn, N.Y.: Institute of Mediaeval Music, 1968).

${ }^{27}$ See bar 4 of Pinel's 'Mon cher troupeau sortons' for an example. Catalogue no. 9. Volume II, p.18.

${ }^{28}$ See bar 4 of Pinel's 'Lors que l'on boit' for an example. Catalogue no. 10. Volume II, p.19.

${ }^{29}$ Frederick Neumann, Ornamentation in baroque and post-baroque music: with special emphasis on J. S. Bach (Princeton: Princeton University Press, 1978), p.596.

${ }^{30}$ Neumann, 1978, p.594.
} 
in these airs for more embellishment, especially in the repeats, given that the notation of ornamentation and graces was often lacking in many airs, as commented upon by Bacilly:

The majority of these ornaments are never printed in the music, either because they cannot accurately be reduced to print owing to a lack of appropriate musical symbols, or because it may be thought that a superabundance of markings might hinder and obscure the clarity of an air and thus result in confusion. ${ }^{31}$

Ornamentation was one of the foremost topics of the eighteenth-century debate over French and Italian characteristics in music. Rousseau attacked the declamation in French music as ineffective, whereas Rameau retorted that harmony was a source of expression and ornamentation was essential to the dramatic importance of music. ${ }^{32}$ Despite a plethora of offerings on seventeenthand eighteenth-century French vocal ornamentation, there are many inconsistencies. It would seem, however, that most agreed that extra flourishes should not be added to the detriment of either the music or the text. Similarly, many had the same opinion that the French style of singing had a nobility and subtleness to it, even to the point of restraint: ${ }^{33}$ "The style of the Opéra François or of the Royal Academy of Music must be noble, the Port de voix accented and sensitive, the vocal ornamentation detached, and the text well articulated...,34 Lambert was praised for mastering these qualities.

La vocale Françoise est fort retenue sur les BRODERIES; ...le Chant François ayant pris un ton plus traînant et plus lamentable encore depuis quelques années, ne les comporte plus. Les Italiens s'y donnent carrière: C'est chez eux a qui en fera advantage; emulation que mene toujours à en faire trop. ${ }^{35}$

In eighteenth-century airs, the application of graces continued to be left up to the performer in many instances:

31 Bacilly, H1668, p.135 as cited by Kah-Ming Ng, 'Ornaments $>$ French Baroque $>$ Historical Overview’, Grove Music Online ed. L. Macy (Accessed 15 April 2008), http://www.grovemusic.com.

32 Mary Cyr, 'Eighteenth-century French and Italian singing: Rameau's writing for the voice', Music \& letters, Vol. 61, no. 3-4, Jul-Oct 1980, p.324.

${ }^{33}$ Elizabeth Hehr, 'How the French viewed the differences between French and Italian singing styles of the $18^{\text {th }}$ century', International Review of the Aesthetics and Sociology of Music 16/1 (June, 1985), pp.75-76.

34 'Le Genre de l'Opéra François ou de l'Académie Royale de Musique doit être noble, les Portde-voix marqués et sensibles, les Agréments du Chant detaches, les Paroles bien articulées...' Raparlier, Principes de Musique, des agreements du chant et un essai sur la pronunciation, l'articuation et la prosodie de la langue française Lille, 1772, p.16 cited in Hehr, 1985 p.76.

35 'French vocal music is very reserved about EMBELLISMENTS;...French song, which has become more dragging and more woeful for several years now, does not allow them anymore. The Italians make a career out of them. It is there [Italy] that one uses many more, a competition that always leads to doing more than necessary.' Jean-Jacques Rousseau, Dictionnaire de Musique (Paris, 1768), pp.59-60 cited in Hehr, 1985, p.77. 
To sing or play proprement is to execute French melody with the ornaments that suit it. This melody, being nothing by the mere force of the sounds, and not having by the same any character, only receives it [character] by the affective contours that one gives it in executing it. These contours, taught by the masters of goût du chant, make up what one calls the agrémens of French song. ${ }^{36}$

\section{RHYTHMIC ALTERATION}

One of the types of rhythmic alteration specific to late seventeenth- and early eighteenth-century French music came about through notes inégales. In this technique of performance, pairs of same-value notes are altered so that the first is lengthened and the second is shortened in proportion to the lengthening of the first, creating a dotted effect. ${ }^{37}$ The extent to which this is done is left up to the performer. An anonymous treatise, 'Maniere de toucher l'orgue...' (1685), suggested that notes inégales provided a piece with 'grace, mouvement, beauty, and charm...without which the pieces are dull, without taste. ${ }^{38}$

In interpreting the sections with dotted notes and runs of semi- or demisemiquavers which are imprecise, the written notes cannot be taken too literally and must be given a degree of flexibility. Sometimes dotted notes can be lengthened to the value of a double-dotted note or longer, and the following note or notes are shortened in accordance. ${ }^{39}$ In such cases, the short notes are performed as late as possible. It is up to the performer to determine how to play the flourish or run as best suited to the air.

\footnotetext{
${ }^{36}$ Rousseau. Cited by Kah-Ming Ng, 'Ornaments', Grove Music Online ed. L. Macy (Accessed 5 May 2008), http://www.grovemusic.com.

37 For information on notes inégales, consult Stephen E. Hefling, Rhythmic alteration in seventeenth- and eighteenth-century music : notes inegales and overdotting (New York: Schirmer Books, 1993).

${ }^{38}$ Anon, 'Maniere de toucher lorgue...F-Pa, MS. 3042', quoted in Hefling 1993, p.6.

${ }^{39}$ Mary Cyr, 2005, p.xxv.
} 


\section{Critical Commentary}

References to the source are designated as follows: bar number. Part-names $\left(\mathrm{F}=\right.$ Flute; $\mathrm{Vln}=$ Violin; $\mathrm{V}=$ Voice ${ }^{40} \mathrm{Bc}=$ Basse continue $)$. note number. variant. Note values are abbreviated as follows: $\mathrm{sb} .=$ semibreve, $\mathrm{m} .=$ minim, $\mathrm{c} .=\mathrm{crotch}$, q. $=$ quaver, $\mathrm{sq} .=$ semiquaver, dsq. $=$ demisemiquaver Other abbreviations used: $\mathrm{r} .=$ rest, $\mathrm{k}-\mathrm{s} .=\mathrm{key}$ signature, $\mathrm{t}$-s. $=$ time signature, om. $=$ omitted

Middle $\mathrm{C}=\mathrm{c}^{\prime}$

Source: Julie Pinel, Nouveau recueil d'airs sérieux et à boire (Paris: Veuve Boivin, Le Clerc, 1737), F-Pn / Vm7 629

\section{Printems. Air sérieux avec accompagnement de Flûtes}

1. F., V., Bc. t-s. 2 emended to $\mathrm{C}$ to agree with the rhythm and beaming of the air.

7. F. 2. dotted sq. emended to match the other instances in the air with this figuration (i.e. b.14)

39. F. 2. c.

39. F. 4-5. sq.

41. F. 4. c.

79. 'Au haut de la page 3 jusq'au mot FIN' om.

\section{Mes yeux ne versez plus de pleurs. Air sérieux}

16. V. 1. f" sharp on grace note is unnecessary given the key signature.

22. Bc. 1. a

42. V. 12. d'"

\section{3. Échos indiscrets, taisez vous. Air sérieux}

10-11. V. the value of the dotted note extends over the bar line and this has been emended as a tied note.

\footnotetext{
${ }^{40}$ In any duos, the part name is specified as $\mathrm{V}(1)=$ voice on the upper stave and $\mathrm{V}(2)=$ voice on the lower stave. For example, see the notes for 'Buvons Lucas'.
} 
20. Bc. 2. dotted e

30. V. 1. f' grace note

4. Funeste ennemy de la paix. Air sérieux

8. V. 1-4. c.

\section{Amans constans. Air à boire}

23-24. V. the value of the dotted note extends over the bar line and this has been emended as a tied note.

\section{Ruisseaux, suspendez vôtre cours. Air sérieux}

37. V., Bc. 1. dotted m. emended to ensure there are a correct number of beats during the section repeat.

\section{De la philosophie. Air à boire>récit de Basse-Taille}

\section{Les charmes de l'indifférence. Air sérieux}

Spelling of title: 'l'indiference'

11. Bc. 1. g flat emended due to modern barring.

24. V., Bc. 1. dotted m.

101. V., Bc. Double dotted barline suppressed.

\section{Mon cher troupeau. Air sérieux>brunette}

\section{Lors que l'on boit à mes amours. Air sérieux}

19. Bc. 1-2. sq.

20. V., Bc. dotted m. emended to ensure there are a correct number of beats during the section repeat.

\section{Que Tircis est charmant. Air sérieux}

1., 9., 26. V., Bc. $\$$ removed because the repeat signs and first and second time endings provide sufficient instruction

9. V., Bc. emended to include time signature change to $3 / 4$ 
15-16. V. the value of the dotted note extends over the bar line and this has been emended as a tied note.

21. V. 4. 'n'est' emended to 'est' to match the previous statement of this line given that this is an extended binary air.

25. V. 1. c.: emended to match the basse-continue line and the 96 figuring

25. V. 5. q.: emended to match the basse-continue line

\section{Buvons Lucas. Air à boire $>$ duo}

37. V(1). 1- 4. c.

47. V(2). 1. m.

\section{Apres m’avoir formé les plus aimables chaines. Air sérieux}

\section{Sombres lieux, obscures forrets. Air sérieux}

17. Bc. 1. m.

\section{Scène Pastorale.}

4. $V(2) .1$. c.

19. Bc. 3-4. c.

32. $\mathrm{V}(1) .1,2$. c.

85-86. $\mathrm{V}(2)$. the value of the dotted note extends over the bar line and this has been emended as a tied note.

Duo.

42-43. V(1). the value of the dotted note extends over the bar line and this has been emended as a tied note.

16. Musette pour un berger. Air sérieux

17. Musette pour une bergere. Air sérieux

18. Tendres amans qu'amour engage. Air sérieux

27. V. 1. 'nast' 
19. Amans qui languissez. Air à boire>récit de Basse

35. V. 1-2. 'seiche'

71. empty bar removed

20. Buvons tous à la ronde. Air à boire $>$ fanfare

21. Boccages frais. Air sérieux $>$ brunette à deux Dessus

\section{Deuxième couplet: Mais je l'entends}

31. V(1)., V(2). 6-7. q.

31. $V(2) .4-5$. tie added to match other voice part

22. Célimeine à changé. Air à boire à deux Voix Egales

1. V(1)., V(2). pick-up bar. c-r. om. emended to make final bar match pick-up bar

4. V(1). 3-5. c.

23. Pourquoy le berger qui m'engage. Air sérieux $>$ brunette à deux Dessus 10. $\mathrm{V}(1)$. 2-5. emended to match the other instance in the air with this figuration (third couplet, bar 9)

\section{Deuxième couplet: Faut-il que son coeur}

10. $\mathrm{V}(1)$. 2-5. emended to match the other instance in the air with this figuration (third couplet, bar 9)

Troisième couplet: En vain je ressens

14. Bc. $3.5 \#$ emended to avoid a clash with the top vocal part.

24. Trop longtems à Bacchus. Air à boire $>$ duo

\section{Le Printems. Cantatille}

Final air:

59. Fl/Vln. 6. dotted c. 
26. Que les mortels sont misérables. Air à boire> récit de Basse

27. De richésses amy je ne suis point jaloux. Air sérieux

23. Bc. $4 .{ }^{7 b}$ emended to avoid clash with the vocal part.

28. Pour guérir sans retour la plus vive bléssure. Air à boire> récit de Basse

29. Dieu du vin quelle est donc ta fatalle puissance. Air à boire

30. Ah que l’homme est sçavant. Air à boire> récit de Basse

31. L'autre jour pres d'un bosquet. Air à boire>vaudeville 


\section{Texts and translations}

\section{Printems}

Rossignols vous chantez les douceurs du printems, Le tendre amour qui vous anime,

Par vos aimables sons s'exprime,

Et les rend encor plus charmans.

Mon coeur hélas est aussy la victime

Du Dieu que célébrent vos chans.

Mais pour moy ce seroit un crime

De laisser éclatter les feux que je ressens.

Chantez les douceurs du printems,

Heureux oiseaux, l'amour qui vous anime

Par vos aimables sons s'exprime,

Et les rend encor plus charmans.

\section{Mes yeux ne versez plus de pleurs}

Mes yeux, ne versez plus de pleurs;

Tircis vient calmer mes allarmes.

Loin de lui montrer mes douleurs

A son aspect brillez de nouveaux charmes.

L'absence d'un objet aimé

Accable un coeur fidelle et tendre,

Mais quand l'amour veut nous le rendre

Qu'il est doux de revoir ce qui nous a charmé.

Mes yeux, ne versez plus de larmes.

Tircis vient finir mes malheurs

Loin de lui montrer mes douleurs

A son aspect brillez de nouveaux charmes.

\section{3. Échos indiscrets, taisez-vous}

Échos indiscrets, taisez-vous,

N'allez pas répetter le nom de ce que j'aime.

Les Dieux mêmes seroient jaloux

De voir mon sort égal a leur bonheur Suprême.

Si Venus connoissoit l'objet de mon amour

Elle abandonneroit le céleste séjour,

Pour m'arracher un amant que j'adore.

Ah, cachons bien le feu qui me dévore,

On trouveroit mon sort trop doux

Échos indiscrets, taisez-vous,

Faut-il vous le redire encore?
Nightingales you sing of the sweetness of the spring,

The tender love that animates you,

Expresses itself in your sweet sounds,

And makes them even more charming.

My heart, alas, has also fallen victim

Of that God whom you celebrate in song.

For me it would be a crime

To give expression to the fires of passion I am feeling.

Sing again of the sweetness of spring,

Happy birds, Love animates you

And is expressed in every lovely sound you make,

And makes each note more charming. ${ }^{41}$

My eyes, do not shed any more tears;

Tircis is coming to calm my fears.

Instead of showing him my pain

Shine for him with new charms.

The absence of a loved one

Overwhelms a faithful and tender heart,

But when love wants to return it to us

How sweet it is to see again what has charmed us.

My eyes, do not shed any more tears.

Tircis comes to end my misfortunes

Instead of showing him my pain

Shine for him with new charms.

Be still, indiscreet echoes,

Do not repeat the name of my beloved.

The Gods themselves would be jealous

To see my fortune equal to their supreme bliss.

If Venus knew the object of my love

She would abandon her celestial abode,

In order to rob me of the lover whom I adore.

$\mathrm{Ah}$, hide well the flame which devours me,

Others would find my lot too sweet

Indiscreet echoes, be silent,

Must I tell you again? ${ }^{42}$

\footnotetext{
${ }^{41}$ The translations included are a mixture of my own, and those found in the sources consulted. Translated by $\mathrm{T}$. Jefferson Kline, La Donna Musicale, The Pleasures of Love and Libation: Airs by Julie Pinel and other Parisian women, directed by Laury Gutiérrez (La Donna Musicale - LA 07103: Boston, 2007).

${ }^{42}$ Margaret Hunter, 2007.
} 


\section{Funeste ennemy de la paix}

Funeste ennemy de la paix,

Autheur de mes tristes allarmes,

Perfide Amour,

Tu ne te plais qu'à voir verser du sang,

A voir couler des larmes.

La cruauté forge tes traits

Ils font naitre en nos coeurs l'espoir qui les abuse,

Et tu n'as un bandeau que pour servir d'excuse

Aux injustices que tu fais.

\section{Amans constans}

Amans constans vous pouvez boire;

L'amour n'en sera point jaloux,

Et bien loin d'offenser sa gloire

Croyez que son triomphe

En deviendra plus doux.

La beauté qui vous a sçu plaire

Verra célébrer ses attraits,

Et lors qu'elle prendra son verre,

L'Amour y trempera ses traits.

\section{Ruisseaux, suspendez vôtre cours}

Ruisseaux, suspendez vôtre cours,

Oiseaux cessez votre ramage,

L'objet de mes tendres amours

Est devenu volage:

L'ingrat vient de trahir sa foy.

Je croy de ma douleur tout doit être l'image!

Qu'un silence effrayant regne dans ce boccage;

Que tout devienne aussy triste que moy!

Le perfide me fuit, hé, quelle dure loy

Me force en le perdant a l'aimer davantage?

\section{De la philosophie}

De la philosophie

J'ay formé je le pense un Sisthéme certain

Et $\mathrm{j}$ 'ay pour le prouver à tout le genre humain

Et Bacchus et Silvie:

Pour braver du destin les biseares décrets

Le vin sçait me donner un courage invincible;

Et je ne connois point de plaisir plus sensible

Que de suivre l'Amour quand il lance ses traits.

\section{Les charmes de l'indifférence}

Charmant repos, paisible indifférence,

Que votre empire a de douceur!

Vos plaisirs font tout mon bonheur.

Et jamais sous votre puissance

L'on n'entend soupirer un coeur,

Charmans repos, paisible indifférence.

Que votre empire a de douceur!

Des prez la riante verdure,

Les doux concerts de mille oiseaux,

D'un ruisseau l'aimable murmure,

Ont des attraits pour moy toujours nouveaux,

D'un amant léger l'inconstance

Ne fera point couler mes pleurs.
Fateful enemy of peace,

Author of my sad fears,

Treacherous Cupid,

You take delight only in seeing blood shed,

And in seeing tears flow.

Cruelty forges your traits

They give birth in our hearts to foolish hope,

And you have only a blindfold to serve as an excuse

For the injustices which you bring about.

Constant lovers, drink up;

Cupid will not be jealous,

And far from offending his glory

Believe that his triumph

Will become more sweet because of it.

The Beauty who has known how to please you

Will see her charms celebrated,

And when she picks up her glass,

Cupid will dip his arrows in it.

Streams, suspend your course,

Birds, stop your singing,

The object of my tender love

Has become fickle:

The ingrate has betrayed his oath.

To my mind everything must reflect my pain!

May a terrible silence reign in this grove;

May everything become as sad as me!

The traitor flees from me, o, what cruel law

Forces me to love him more even as I am losing him?

About philosophy

I have formed, methinks, a sure theory

And I have, to prove it to all mankind

Both Bacchus and Silvie:

To defy the strange decrees of destiny

Wine can give me an invincible courage;

And I know no keener pleasure

Than to follow Cupid when he throws his arrows.

Charming rest, peaceful indifference,

How sweet is your empire!

Your pleasures are all my happiness

And never under your power

Does a heart sigh,

Charming rest, peaceful indifference.

Your empire of softness!

The cheerful greenery of the fields,

The soft song of a thousand birds,

The kindly murmur of a stream

Have ever new charms for me,

The inconstancy of a light, fickle lover

Will not make me shed tears. 
Je n'éprouveroit point ces mortelles douleurs Qui souvent sont le prix de la perséverance.

Charmans repos, paisible indifférence,

Que votre empire a de douceur!

Vos plaisirs font tout mon bonheur.

Et jamais sous votre puissance

L'on n'entend soupirer un coeur,

Charmant repos, paisible indifférence,

Que votre empire a de douceur!

Je méprise l'Amour, j'ygnore ses allarmes,

Ses plus doux traits sont sur moy

Sans pouvoir, et sans pitié je vois le déséspoir

De ceux qui comtoient sur ses charmes.

Que votre empire a de douceur!

Charmant repos, paisible indifférence,

Vos plaisirs font tout mon bonheur.

Charmant repos. Paisible indifférence,

Que votre empire a de douceur!

\section{Mon cher troupeau}

Mon cher troupeau, sortons de ce boccage,

Fuyons les bergers et les loups.

Les uns sont à craindre pour vous,

Et les autres pour moy le sont bien d'avantage.

\section{Lors que l'on boit à mes amours}

Lors que l'on boit à mes amours

C'est à vous que l'on boit, adorable Silvie.

Ah que j'aurois l'âme ravie,

Que je passerois d'heureux jours

Si l'on buvoit à moy Silvie

Lors que l'on boit à vos amours.

\section{Que Tircis est charmant}

Que Tircis est charmant, et qu'il est amoureux; Il me rend mille soins dont je suis allarmée.

Ah, qu'il est dangereux

Quand on est tendrement aimée

De sentir qu'un amant est digne d'être heureux.

\section{Buvons Lucas}

Buvons Lucas, mais buvons tant, Luy disoit Grégoire en pintant Qu'il en soit parlé dans l'histoire:

Des Héros précédens surpassons la mémoire, Le verre en main forçons leurs noms fameux A ne plus marcher qu'apres ceux Du grand Lucas et de Grégoire.

\section{Apres m’avoir formé les plus aimables chaines}

Apres m'avoir formé les plus aimables chaines, L'amour livre mon coeur aux plus cruels soupirs: Ah si ses doux plaisirs font oublier ses peines, Ses tourmens ne font pas oublier ses plaisirs.
I will not feel those terrible pains

Which are often the rewards of perseverance.

Charming rest, peaceful indifference,

How sweet is your empire!

Your pleasures are all my happiness.

And never under your power

Does a heart sigh,

Charming rest, peaceful indifference.

How sweet is your empire!

I scorn Cupid, I am ignorant of the troubles he causes, His softest traits have no power over me,

And without pity, I look on the despair

Of those who were relying on his charms.

How sweet is your empire!

Charming rest, peaceful indifference,

Your pleasures are all my happiness.

Charming rest. Peaceful indifference,

How sweet is your empire!

My dear flock, let us come out of this grove, Let us flee from the shepherds and the wolves. The first are to be feared for your sake, The others are even more to be feared for my sake.

When they raise a glass to my amours It is to you that they drink, adorable Silvie. Ah how my soul would be in rapture, How I would spend happy days If they were raising a glass to me, Silvie When they are drink to your amours.

How charming Tircis is, and how loving;

He renders me a thousand services which have me worried.

Ah, how dangerous it is

When one is tenderly loved,

To have the feeling that a lover is worthy of being happy.

Let's drink Lucas, let's drink such a lot, Said Gregory as he drank a draft That it will go down in history:

Let's outdo the Heroes of yore,

With glass in hand let's force those famous drinkers

To follow henceforth in the wake

Of great Lucas and Gregory.

Having formed for me the most loving bonds, Cupid delivers my heart to the cruellest sighs: Ah if his sweet pleasures make one forget his sorrows, His torments do make one forget his pleasures. 


\section{Sombres lieux, obscures forrets}

Sombres lieux, obscures forrets,

Vous paroissez sensible au tourment que j'endure;

Quand vous abandonnez votre aimable parure

Vous semblez partager tous mes ennuis secrets.

Un triste éloignement m'arache à ce que j'aime,

Mais si l'amour couronnant nos soupirs

Nous rassemble en ces lieux au gré de nos désirs,

Bois charmant secondez une tendresse extrême

De vos ombres, formez s'il ce peut la nuit même

Pour mieux cacher l'excés de nos plaisirs.

\section{Scène Pastorale}

Iphis: Belle Daphné, je sçay votre secret

Vous disiez l'autre jour à la jeune Climeine

Que votre coeur pourroit céder sans peine,

A l'ardeur d'un amant discret,

Si c'est au plus constant que vous devez vous rendre.

Ah vous ne devez plus attendre,

Connoissez aujourd'huy

L'exces de mon amour;

Tout est paisible en ce séjour

Rien ne peut nous être contraire,

Non, vous qui sçavez tout charmer,

Vous m'instruirez dans l'art de plaire,

Je vous apprendray l'art d'aimer.

Daphné: Que ce discours doit me surprendre Iphis, vous bruleriez pour moy,

Que tardiez vous à me l'apprendre?

Hé, si quelqu'autre amant avoit reçeu ma foy

De quel succes votre flamme suivie?

Iphis: Mon désespoir m'arracheroit la vie Mais quel éffroy vient me saisir,

Quel est l'heureux rival qui prétend me ravir

L'unique objet qui receüs mon hommage,

Ah! courrons le chercher, sans tarder d'avantage.

Daphné: Cessez Iphis de vous troubler.

Ce rival supposé, qui vous a fait trembler,

Étoit l'ouvrage de ma crainte.

Rappellez votre espoir et pardonnez ma feinte.

Iphis: Vous rendez la paix à mon coeur

En le troublant des plus douces allarmes,

Hattez-vous, cher objet, qu'un aveu plein de charmes

Acheve aujourd'huy mon bonheur.

Daphné: Que voulez-vous encor et que puis-je vous dire;

C'est pour moy, dites vous, que votre coeur soupire.

Si d'un amour constant, vous êtes enflammé

Joignez-y l'espoir d'être aimé.

Iphis: Que mon soir est charmant, trop aimable bergere,

Vous m'aimez, que je suis heureux,

Promettez-moy de n'être point légère

Vous aurez comblé tous mes voeux.
Sombre places, obscure forests,

You seem sensitive to the torment that I endure;

When you give up your adornment

You seem to share all my secret troubles.

A sad estrangement keeps me from what I love,

But if love crowning our sighs

Gathers us in these places at the whim of our desires,

Charming woods, please support my love

With your shadows, form night itself, if you can,

The better to hide the abundance of our delights.

Iphis: Beautiful Daphne, I know your secret

You told young Climeine the other day

That your heart could surrender without difficulty,

To the ardour of a discrete lover,

If it is to the most faithful that you would surrender yourself.

Ah, you should no longer wait,

Know today of

The great extent of my love;

All is peaceful here

Nothing can ever be against us,

No, you who know how to charm everyone,

You will teach me the art of pleasing,

I will teach you the art of loving.

Daphné: These words take me by surprise

Iphis, you would burn with love for me,

Why did you wait to tell me?

Ah, if I had sworn my devotion to another lover

What success [would] your burning love [have had]?

Iphis: My despair would end my life

But what dread takes hold of me,

Who is this rival who claims to take from me

The unique object of my homage,

$\mathrm{Ah}$ ! let us quickly search for him without delay.

Daphné: Stop upsetting yourself, Iphis.

This imaginary rival, who made you tremble,

Was the creation of my fear.

Bring back your hope and excuse my deception.

Iphis: You bring peace to my heart

By disturbing it with the sweetest alarms,

Hasten, beloved, let your confession full of charms

Bring about my happiness today.

Daphné: What else do you want and what may I tell you;

It is for me, you say, that your heart sighs.

If you are ablaze with a faithful love,

Add to it the hope of being loved in return.

Iphis: How sweet is my evening, most lovable shepherdess

You love me, how happy I am,

Promise me that you will not be unfaithful

You will have fulfilled all my dreams. 
Daphné: Je vous promets une flâme eternelle, Mais quand je vous donne ma foy

Par un serment assurez-moy

Que votre coeur sera fidelle.

Iphis: J'en atteste ces lieux à Pâlés consacrez, Ces bois de nos bergers en tous tems revérez, Puissent ces arbres verds dépouillez de verdure Ne reprendre jamais leur aimable parure

Puissent ces lieux charmans être d'affreux déserts $\mathrm{Si}$ jamais je brise mes fers.

Duo. Ensemble: Fuyons la grandeur souveraine, Aimons, cédons à nos desirs, Craignons l'éclat dans les plaisirs

Que nous prépare notre chaine.

\section{Musette pour un berger}

La paix qui regne en nos aziles

Nous assure un parfait bonheur;

Nous fuyons le bruit des villes,

La pompe des Rois nous fait peur:

Loin de nous la cruelle envie,

Peut faire tonner sa voix;

La simplicité de notre vie

Nous donne de plus douces loix.

Nous allons sur les fougeres chanter nos tendres amours,

La beauté de nos bergeres,

Est sans art et plaist toujours.

\section{Second couplet. Parodie du premier}

Sans cesse nos riches campagnes

Nous présentent d'aimables fleurs

Pour en parer nos compagnes

Nous assortissons les couleurs:

Au son de nos douces Musettes

Nous déclarons nos ardeurs,

Et par mille tendres chansonnettes,

Nous trouvons le chemin des coeurs.

Le respect nous sert de guide

Et nous meine au vray bonheur,

L'amour soumis et timide

Souvent demeure vainqueur.

\section{Musette pour une bergere}

Douce innocence

Régne sur nos coeurs

Chere ignorance

Des biens séducteurs.

Ta jouissance

Conserve nos moeurs,

Et l'espérance

Des vaines grandeurs

N'a point de puissance,

Où l'on s'en tes faveurs:

Notre heureuse vie

Coule sans envie,
Daphné: I promise you an eternal love,

But when I give you my devotion

With an oath assure me

That your heart will be faithful.

Iphis: I swear to it by all that Pallas holds dear These woods [that] our shepherds forever revere, May these green trees stripped of their leaves Never take back their lovely finery

May these charming fields be hideous deserts

If I ever break my vows.

Together: Let us flee all grandiose display, Let us love each other, and give in to our desires, Let us fear the intensity that in [our] pleasures Our chain prepares for us. ${ }^{43}$

The peace which reigns in our retreat Assures us a perfect happiness;

We escape the noise of cities,

The pomp of Kings frightens us:

Far from us cruel desire,

Can make its voice thunder;

The simplicity of our life

Gives us sweeter laws.

On the heaths we sing of our tender

love,

The beauty of our shepherdesses,

Is artless and always pleases.

Constantly our rich countryside

Presents us with lovely flowers

In order to adorn our companions with them

We match their colours:

At the sound of our sweet musettes

We declare our ardour,

And with a thousand tender songs

We find the way to the heart.

Respect serves us as a guide

And leads us to true happiness,

Subjected and timid love

Often remains victorious.

Sweet innocence

Rules over our hearts

Dear ignorance

Of seductive things.

Taking pleasure in you

Keeps our customs safe,

And longing

For empty grandeur

Has no power,

For one in your favour:

Our happy life

Flows without envy,

${ }^{43}$ Catherine Gordon-Seifert, 2007. 
Nos bergers contens,

Sont toujours constans.

Quand un amant jure

D'adorer nos yeux,

Sa foy simple et pure,

Nous assure mieux

Que lors qu'un parjure,

Atteste les Dieux.

\section{Tendres amans qu'amour engage}

Tendres amans qu'amour engage,

Craignez de voir trop tôt courronner vos désirs;

Ménager ce doux avantage

Pour augmenter le prix de vos plésirs:

L'amant constant bientôt languit,

Son feu contraint s'acroist par l'espérance

Mais bien souvent du prix de la constance

Naist le moment qui la détruit.

\section{Amans qui languissez}

Amans qui languissez sous de pesantes chaînes

Redoublez vos soins, vos soupirs;

Essayez de fléchir des rigueurs inhumaines,

Pour arriver aux vrais plaisirs:

Mais si l'objet qui vous engage

Se rit encor de vos douleurs,

C'est Bacchus qui sèche les pleurs

Des amans constants qu'on outrage

Buvez, oubliez vos malheurs,

Que sur un rouge bord

Ils fassent tous naufrage!

\section{Buvons tous à la ronde}

Buvons tous à la ronde

Qu'on nous verse toujours:

Puisse autant que le monde

Durer ce vin et nos amours!

Petit dieu de Cythere

Rends hommage à Bacchus:

Les faveurs de ta mére

Se doivent souvent à son jus.

Iris à cette table

Determine mon choix:

Que sa voix adorable

Amour-met de coeurs sous tes loix.

\section{Boccages frais}

Boccages frais, aimable Solitude,

Qui d'un coeur amoureux charmez l'inquiétude,

Riches présens de Flore, ornemens de ces lieux

Que l'aurore embellit pour enchanter les yeux:

Habitans de ces bois, oiseaux et vous fontaines,

Qui laissez à vos Eaux des routes incertaines,

Séjour heureux, Azile de la paix,

Quand je vois mon amant que vous avez d'attraits.
Our shepherds,

Content, are always constant.

When a lover vows

To love our eyes,

His simple and pure faith,

Assures us better

Than when a perjurer

Swears by the Gods.

Tender lovers that love binds,

Do not try to see your desires fulfilled too soon;

Treat carefully this sweet advantage

To augment the price of your pleasures:

The constant lover soon languishes,

His fire held back grows through hope

Very often from the reward of constancy

The instant which destroys it is born.

Lovers who languish under heavy chains

Intensify your care, your sighs;

Try to bend inhuman rigour,

To arrive at true pleasures:

But if the loved one who entices you

Laughs still at your pain,

It is Bacchus who dries up the tears

Of constant lovers who are offended

Drink, forget your misfortunes

On a red rim

May they all be shipwrecked!

Let us drink a round

That they always pour out for us:

May this wine and our loves last

As long as the world!

Small God Cythera

Pay tribute to Bacchus:

Favours of your mother

Are often owed to his juice.

Iris at this table

Determines my choice:

What a lot of hearts

Her lovely voice puts under your sway.

Refreshing woods, sweet solitude,

Who charm my loving, anxious heart,

Rich abundance of flora, ornaments of these surroundings

That the dawn embellishes to enchant the eyes:

Inhabitants of these woods, birds and springs,

Who allow your streams to follow uncertain paths,

Happy retreat, peaceful exile,

When I see my lover, how lovely you are. 


\section{Deuxième couplet:}

Mais je l'entens chanter sur sa Musette,

Le moment fortunez qui luy rend sa Lisette,

J'apperçois son troupeau déja je vois son chien

Pour garder nos moutons se joindre avec le mien:

Amour hâte ses pas, que l'espoir le plus tendre

A mes ardens desirs, le presse de se rendre

Charmans oiseaux, redoublez vos concerts,

Et que de nos plaisirs retentissent les airs.

\section{Célimeine à changé}

Célimeine à changé,

Changeons à notre tour,

Dégageons nous d'une fatale chaîne,

Laissons désormais l'inhumaine,

Se livrer aux transports

De son nouvel amour:

Cher Bacchus à jamais,

Je chanteray ta gloire;

Viens combattre en mon coeur

Un trop charmant poison, achèves,

Dieu puissant

$\mathrm{Si}$ je perds la raison

Que ce soit à force de boire.

\section{Pourquoy le berger qui m'engage}

Pourquoy le berger qui m'engage,

Vient-il de ralentir ses feux:

Hélas, s'il doit rompre ses noeuds

Amour, viens me rendre volage.

\section{Deuxième couplet:}

Faut-il que son coeur se dégage,

Si tost que je reçois ses voeux:

Hélas, s'il doit rompre ses noeuds

Vole Amour, et me rends volage.

\section{Troisième couplet:}

En vain je ressens cet outrage;

Mon coeur n'est pas moins amoureux:

L'ingrat peut bien rompre ses noeuds,

Mais je ne puis être volage.

\section{Trop longtems a Bacchus}

Trop longtems à Bacchus j'ay disputé la gloire

De triompher de mon ardeur:

Si ce Dieu, devenu vainqueur,

Sur le cruel amour remporte la victoire,

Je jure d'immoller aux pieds de ses autels

Ce funeste ennemy du repos des mortels.

\section{Cantatille: Le Printems}

Recitatif:

Le Dieu du jour nos rend sa lumière féconde,

Son retour enchante nos yeux
But I hear him singing with his musette,

Of the fortunate moment that brings back his Lisette,

I see his flock, I see his dog

To protect our sheep, now join with mine:

Love hastens his steps, the most tender hope may

Press him to surrender to my ardent desires.

Charming birds, sing again your songs,

And let the sighs of our pleasures resound. ${ }^{44}$

Celimeine has changed,

Let us change in our turn,

Let us rid ourselves of a fatal chain,

Let us abandon the inhuman one from now on,

To deliver herself to the transports

Of her new love:

Dear Bacchus for ever,

I shall sing your glory;

Come and fight in my heart

A too delightful poison, have done with it,

Powerful God

If I lose my reason

May this come to pass through drinking.

Why has the shepherd who is committed to me, Just now let his passion wane:

Alas, if he must break his bonds

Love, come and make me fickle.

Must his heart break its promise

The moment I receive his pledge:

Alas, if he must break his bonds

Fly Love, come and make me fickle.

In vain I feel this insult;

My heart is no less in love:

The ingrate may very well break his bonds,

But I cannot be fickle. ${ }^{45}$

For too long has Bacchus competed for the glory Of triumphing over my ardeur:

If this God, become victorious,

Wins a victory over cruel love,

I swear to sacrifice at the foot of his altars

This disastrous enemy of the repose of mortals.

\section{Recitative:}

The God of daylight grants us his fertile light, His return enchants our eyes

${ }^{44}$ Catherine Gordon-Seifert, 2007.

${ }^{45}$ Catherine Gordon-Seifert, 2007. 
Tout rit sur la terre et sur l'onde, Tout semble renaitre en ces lieux. Le Zéphir va s'unir à Flore,

Bientost de leur tendres amours

Nous allons voir éclore

Mille fleurs avec les beaux jours...

Air:

Chantez, dansez jeunes bergères,

A l'ombre de ces frais ormeaux,

Unissez vos danses légères

Au doux son de nos chalumeaux.

Que l'amour qui regne en nos âmes

Nous inspire de nouveaux sons.

Célébrons l'ardeur de nos flâmes

Par les plus aimables chansons.

\section{Recitatif:}

Déja la riante verdure,

Fruit de l'haleine des Zéphirs

Embellit toute la nature, et rameine

En ces lieux les jeux et les plaisirs,

Tout ressent de l'amour la Suprême puissance,

Toy seule, belle Iris, par ton indifférence

Veux tu payer toujours les tendres feux

De mon coeur amoureux?

Écoute les ramages

De ces heureux oiseaux

Ils t'invittent sous ces feuillages

A soulager mes meaux.

Air:

Doux Rossignols chantez dans ces boccages,

Chantez votre bonheur, je n'en suis point jaloux.

Que vos chants amoureux deviennent les présages

D'un plaisir qui me rend aussy content que vous.

Attendrissez mon aimable inhumaine;

Peignez luy l'ardeur que je sens;

Qu'elle partage enfin ma peine

Redoublez vos divins accens.

\section{Que les mortels sont misérables}

Que les mortels sont misérables

S'écrioit Lucas en fureur,

Chaque jour leur inspire une nouvelle erreur

Un dessein traversé les rend inconsolables:

Insensez, qui voulez combattre un sort malin,

Ce n'est ny l'amour ny la gloire

Qui nous font un heureux destin,

Pour moy tous mes projets se tournent à bien boire.

\section{De richésses amy je ne suis point jaloux}

De richésses amy je ne suis point jaloux,

J'ay pour guide l'amour,

Quel exemple est plus doux?

Ce Dieu content de son partage,

N'a pour bien qu'un carquois,

Des fleches un flambeau,
Everything on earth and on the waters laughs,

Everything here seems to have been reborn.

Zephyr will band together with Flora,

And soon from their tender love

We will see a thousand flowers

Blossom forth with the beautiful days...

Air:

Sing and dance, young shepherdesses, In the shade of these fresh young elm trees,

Join your graceful dances

With the sweet sound of your pipes.

Let love which reigns in our souls

Inspire us to new sounds.

Let us celebrate the heat of our ardour

With the most pleasant songs.

\section{Recitative:}

Already the happy greenery,

Fruit of the breath of the Zephyrs

Beautifies all of nature, and restores

Here our games and pleasures,

Everything senses the mighty power of love,

All but you alone, beautiful Iris, by your indifference

Do you still wish to extinguish

The tender fires of my loving heart?

Listen to the voices

Of the happy birds

Who invite you under the leafy canopy

To ease my suffering.

Air:

Sweet Nightingales, sing in these groves,

Sing of your happiness, of which I am not at all jealous.

Let your amourous songs become omens

Of a pleasure that will make me just as happy as you are.

Soften my lovely inhuman one;

Strike her with the fire that I feel;

So that she will at last take part in my pain

Redouble your heavenly notes. ${ }^{46}$

How wretched are mortals,

Cried out Lucas in rage,

Every day inspires in them a new error

A plan gone awry makes them inconsolable:

You insane folk, who want to fight a clever fate,

It is neither love nor glory

Which makes us a happy destiny,

As for me, my plans are confined to drinking good wine.

Of riches I am not envious

I have love for a guide

Whose example is gentler?

This God, happy with his lot,

Has only a quiver to call his own,

Arrows and a flame,

${ }^{46}$ Margaret Hunter, 2007. 
Satisfait de regner sur les coeurs qu'il engage.

S'il a du superflus

Ce n'est que son bandeau.

\section{Pour guérir sans retour la plus vive bléssure}

Pour guérir sans retour la plus vive bléssure

Le vin est un remede, Hyppocratte l'assure:

Cher amy, verse m'en tout plein

Que dans cet élixir divin mon coeur blessé des traits d'Aminte,

Trouve à jamais sa guérison.

Oh, l'aimable contre poison,

Vidons encore cette pinte.

\section{Dieu du vin quelle est donc ta fatalle puissance}

Dieu du vin quelle est donc ta fatalle puissance,

Verrons-nous sur les coeurs s'étendre ton pouvoir,

Et de tous nos amans ébranler la constance

Ne nous reste-t'il plus d'éspoir?

Viens amour, viens vanger notre commun outrage.

Quand mon Tircis tiendra le funeste breuvage

Qu'une étincelle de ton flambeau,

Tombant dans ce jus que j'abbhore,

Me rende l'amant que j'adore,

Et l'enflâme tout de nouveau.

\section{Ah que l'homme est sçavant}

Ah que l'homme est sçavant, disoit un jour Grégoire, Et que son sort me semble beau quand je le vois

Sur un fourneau travailler suivant un grimoire:

Apres mille travaux l'on ne voit rien encor.

L'on fixe le mercure, on a beau me le dire

Dans un creuset je vois mettre de l'or,

Et de soufleur confus jamais ne l'en retire

Moy, je ne suis ny si fou ny si vain,

Mais je sçais soufler de bon vin.

\section{L'autre jour pres d'un bosquet}

L'autre jour pres d'un bosquet

J'allois cueillir des fleurettes

C'étoit pour faire un bouquet

De naissantes viollettes.

Mais entendant soupirer.

Je voulus me retirer.

Je m'entendis appeller

D'une voix douce et plaintive

Où voulez-vous donc aller?

Qui peut vous rendre craintive?

Hélas bien loin de me füir,

Cherchez a me secourir!

J'approche donc en tremblant

Vers l'éppaisseur du feuillage,

J'y trouve un enfant charmant

Des pleurs baignoient son visage

Hélas, di-je en gémissant

Qui vous rend si languissant?
Satisfied to reign in hearts that he engages over. If he has anything more than that

This is only his blindfold.

To cure for ever the severest injury

Wine is a remedy, Hippocrates assures us:

Dear friend, pour me a full glass

May in this divine elixir my heart hurt by Aminta's shafts

Forever finds its healing,

$\mathrm{Oh}$, what a pleasant antidote it is,

Let us empty this pint once more.

God of wine, what therefore is your fatal potency, Shall we see your power extend over hearts, And of all our lovers the constancy shaken?

Is there no more hope for us?

Come love, avenge our common outrage.

When my Tircis holds the disastrous beverage

May a spark of your light,

Falling in this juice which I loathe,

Return to me the lover whom I adore

And make him burn anew.

Ah how learned is man, said Gregory one day, And how his fate seems beautiful to me when I see him Working at a stove according to a book of magic: After a thousand endeavours we still see nothing Mercury is fixed in solid form, in vain do they tell me I see gold being placed in crucible, Worked on, reduced, but never bringing yield. As for me, I am not so mad or so vain, But I can make good wine disappear.

The other day close to a grove

I was going along picking little flowers

To make a bunch

Of budding violets.

But hearing a sigh.

I wanted to leave.

I heard a call

In a soft, plaintive voice

Where you want to go?

Who is making you fearful?

Alas, please do not flee from me,

Try to rescue me!

I therefore draw near, trembling

To the thick foliage

I find a delightful child there

Tears were bathing his face

Alas, I say with a groan,

Who is making you so languid? 
Regarde, dit-il, ma main;

Par cette épine blessé

Je m'offre à l'ôter soudain

Et sa douleur est passée,

Mais pour prix de ma bonté

Il ravit ma liberté.

Le traitre d'un ris moqueur Décoche un trait et s'envole. Le trait me perce le coeur Mais toute plainte est frivole. Qui craint un semblable tour Doit à jamais füir l'amour.
Look at my hand, he said;

It is wounded by this thorn

I offered to remove it right away

And his pain passed,

But for the price of my goodness

He took away my freedom.

The traitor with a mocking laugh Fires an arrow and flies off.

The arrow pierces my heart

But any complaint is in vain.

Whoever fears a similar trick Must flee love for ever. 


\section{Printems.}

Air sérieux avec accompagnement des Flûtes.
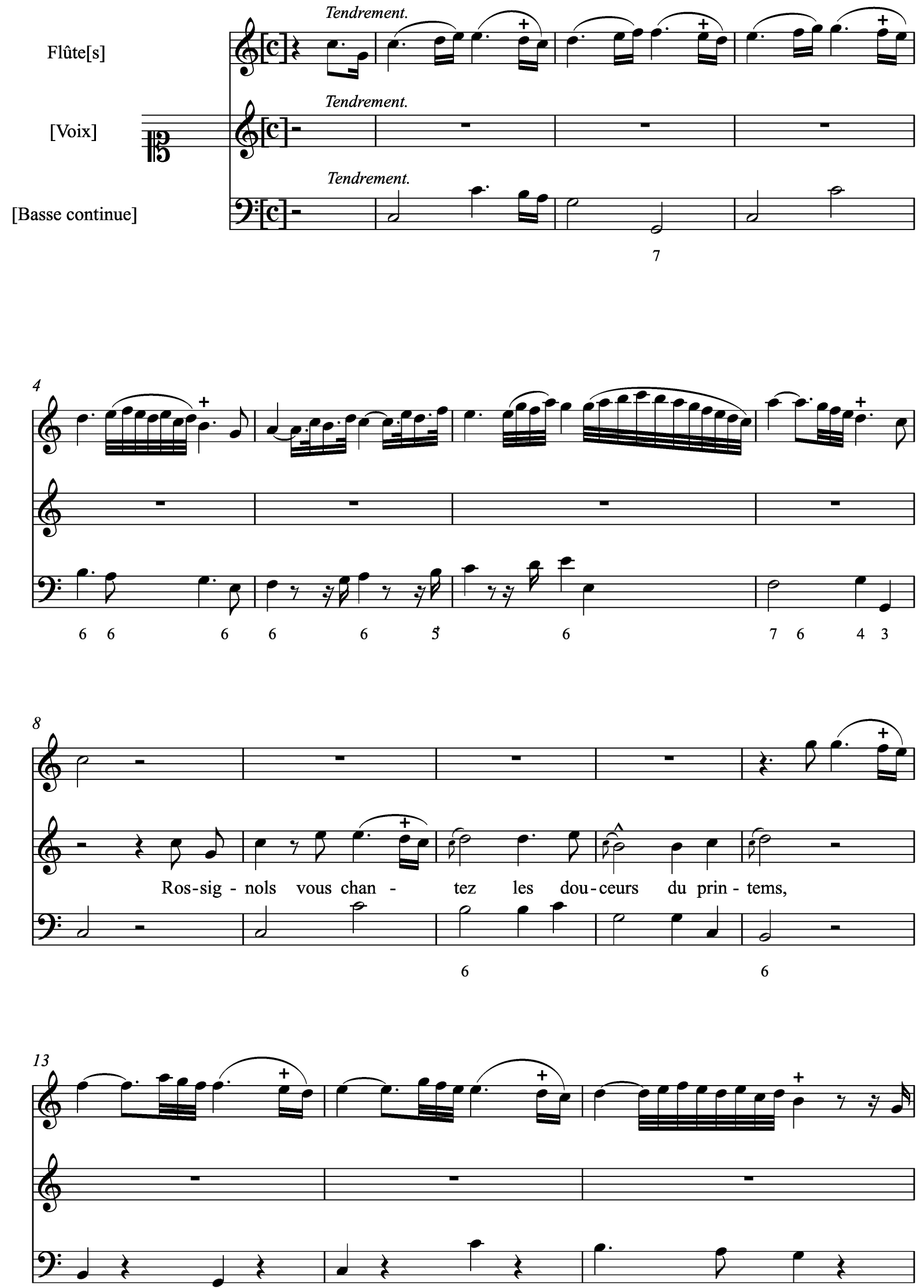

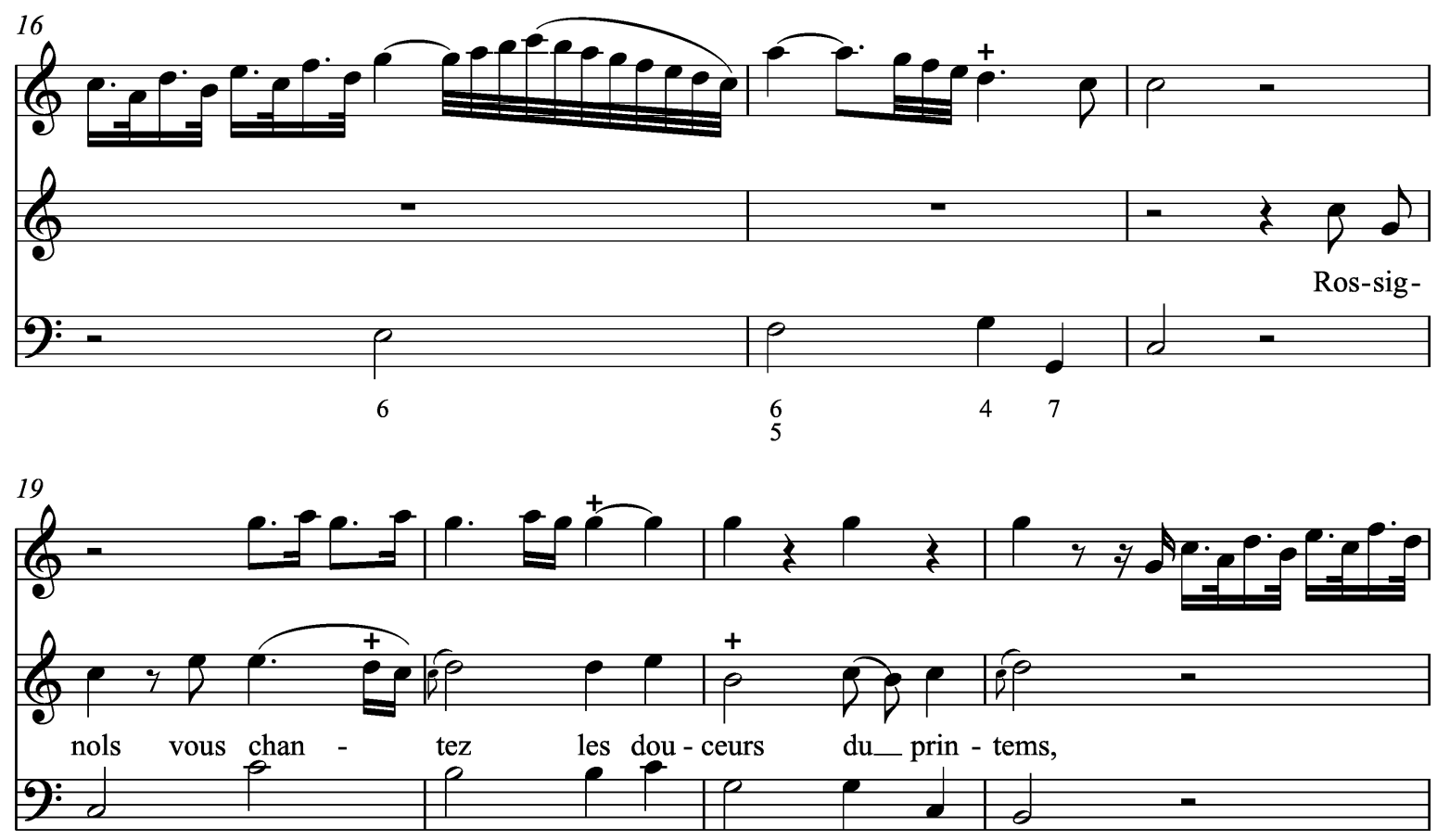

6
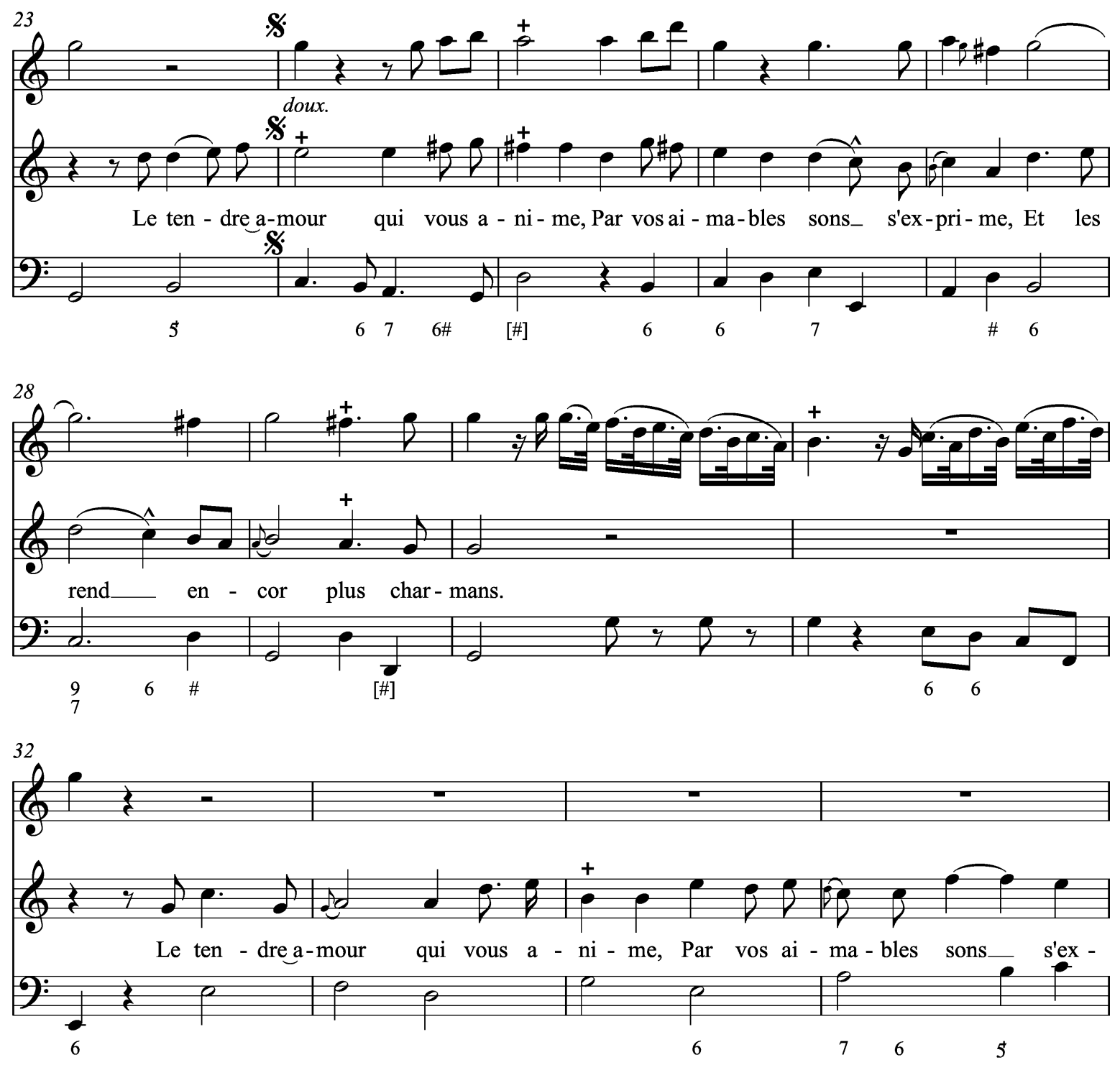

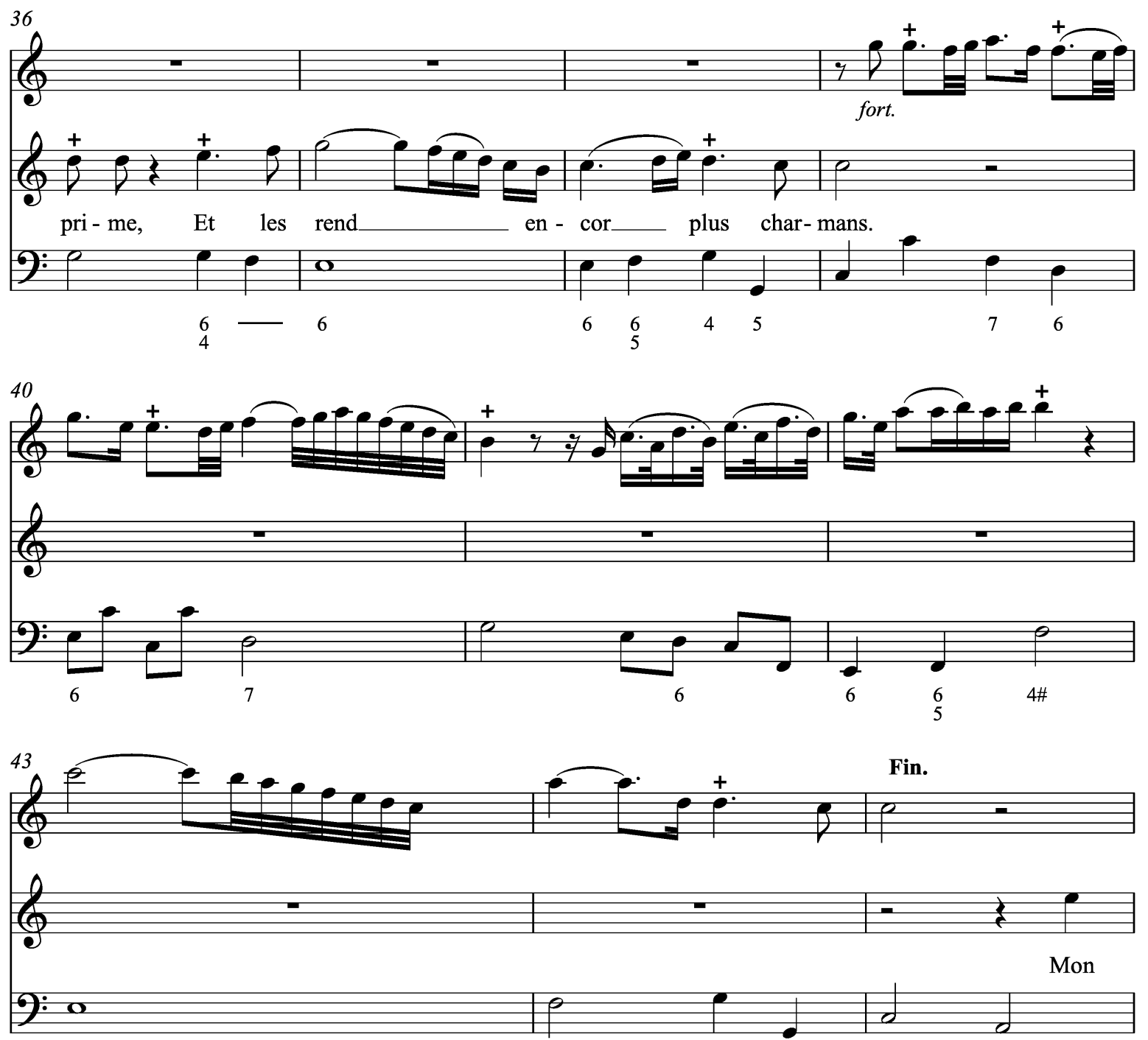

Fin.
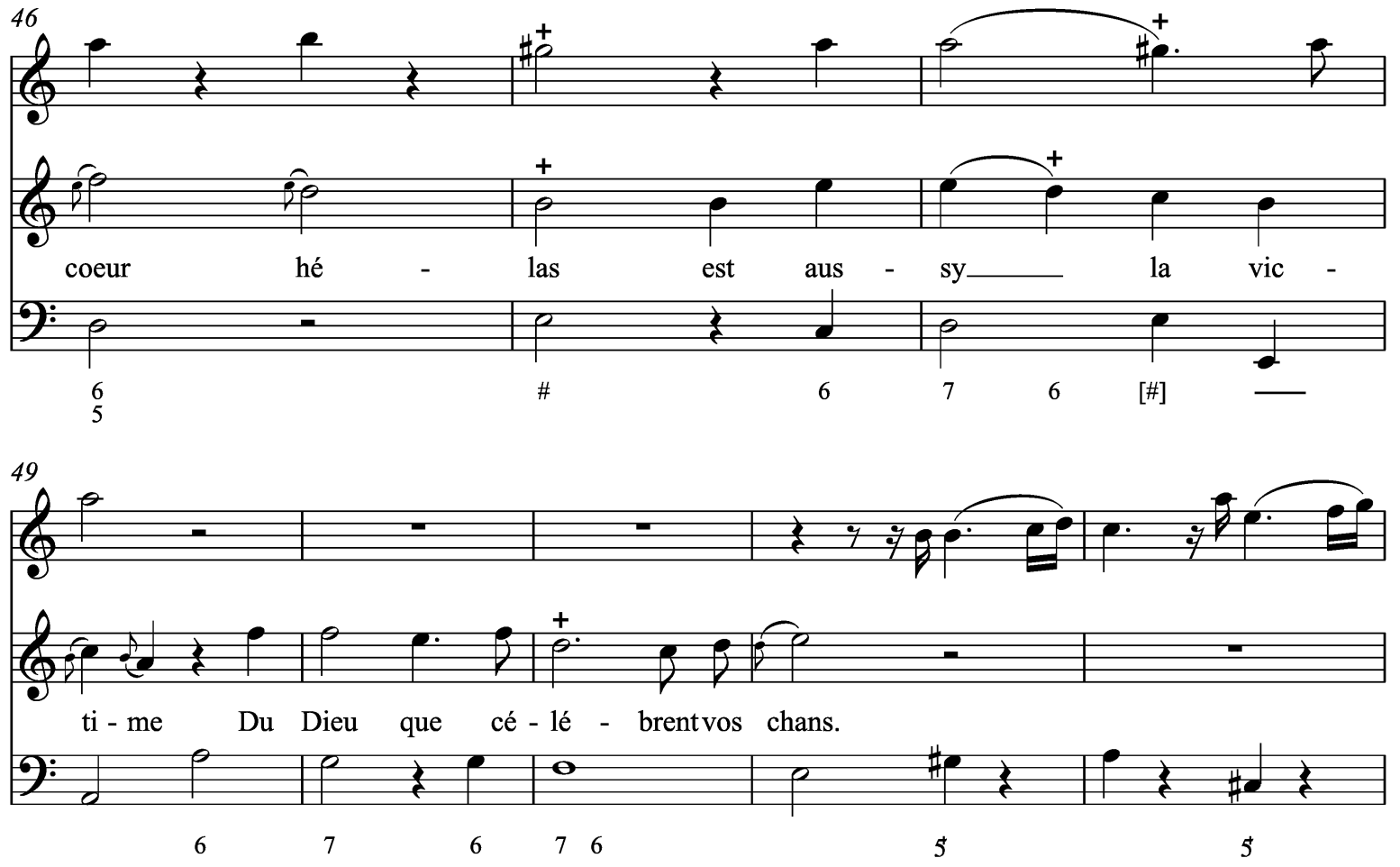

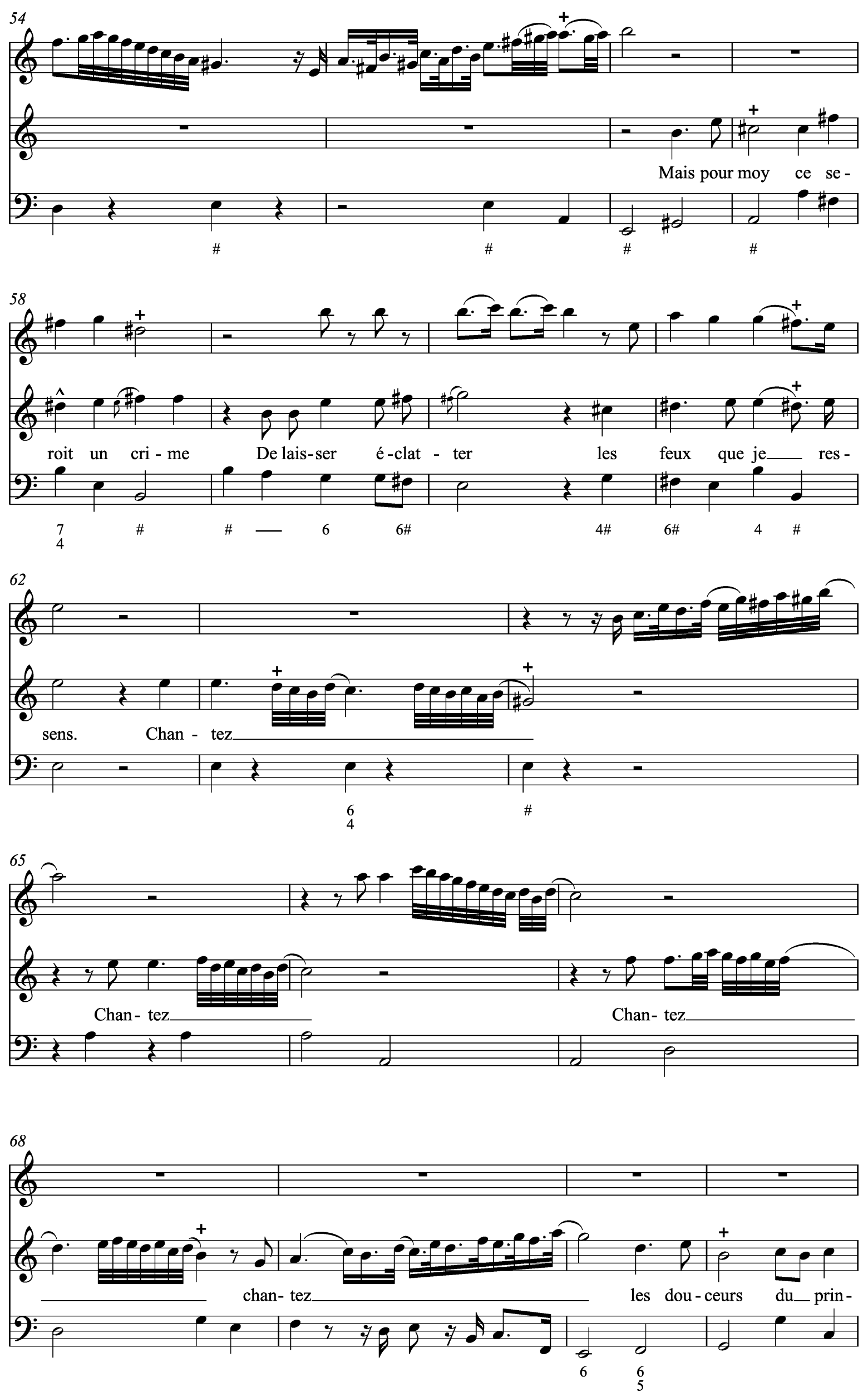

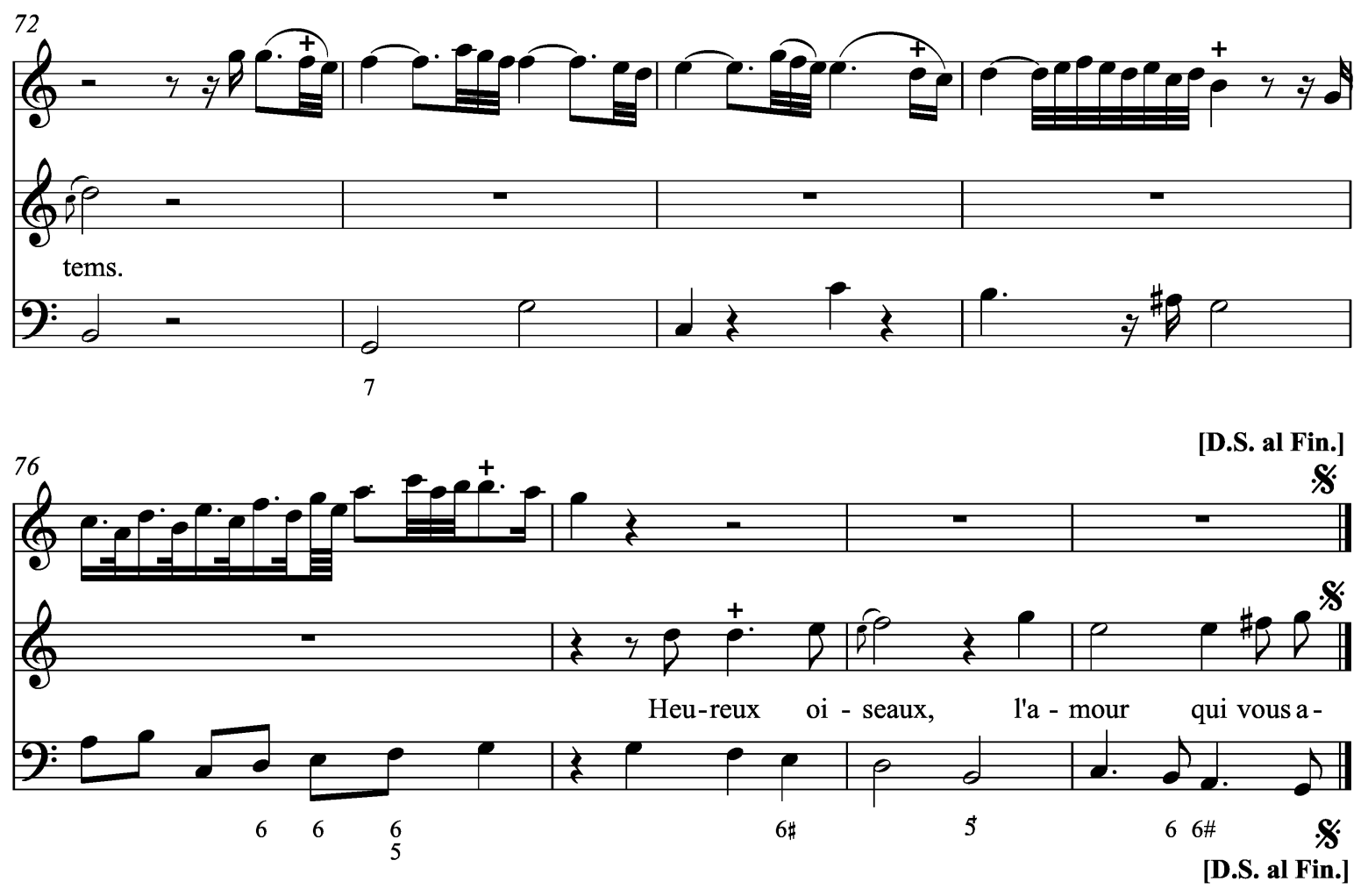
6

\section{Mes yeux ne versez plus de pleurs}

Air sérieux

[Voix]

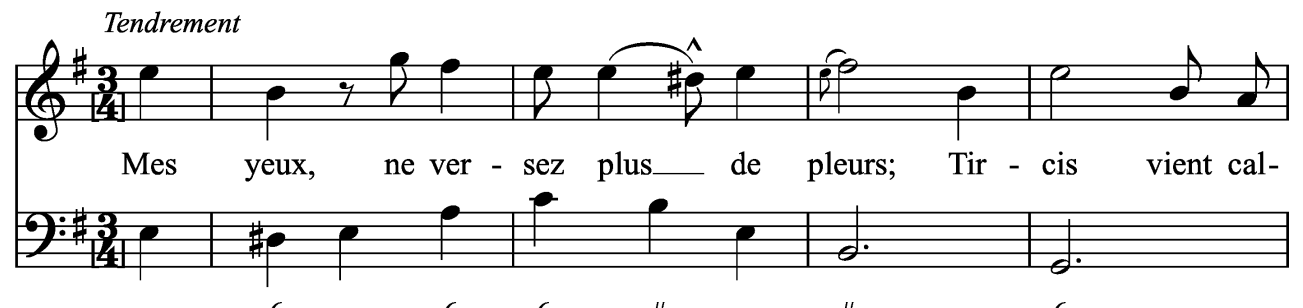

[Basse continue]
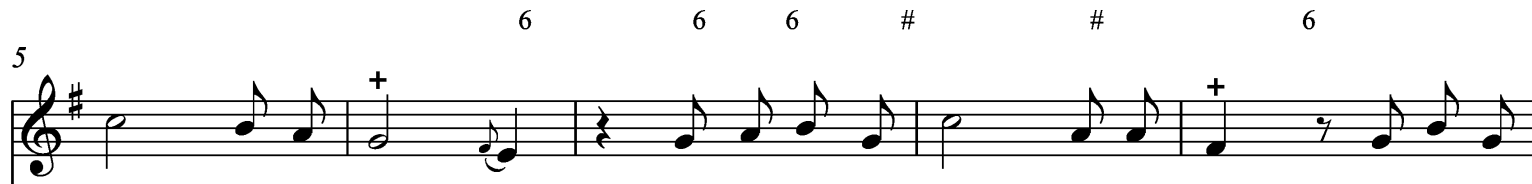

mer mes al - lar - mes. Loin de lui mon-trer mes dou-leurs A son as -
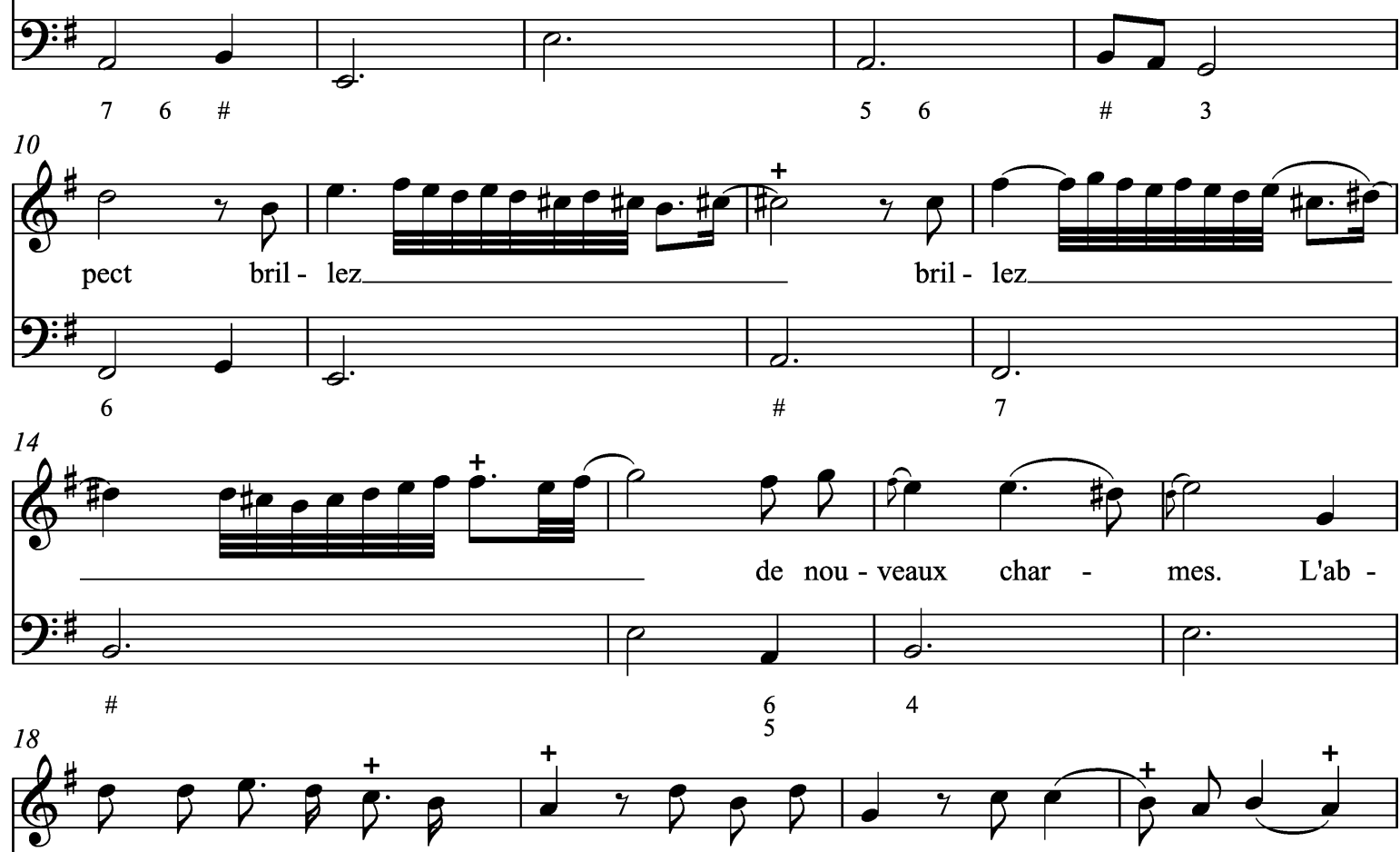
sen - ce d'un ob-jet ai - mé Ac-cable un coeur fi - delle__et ten -
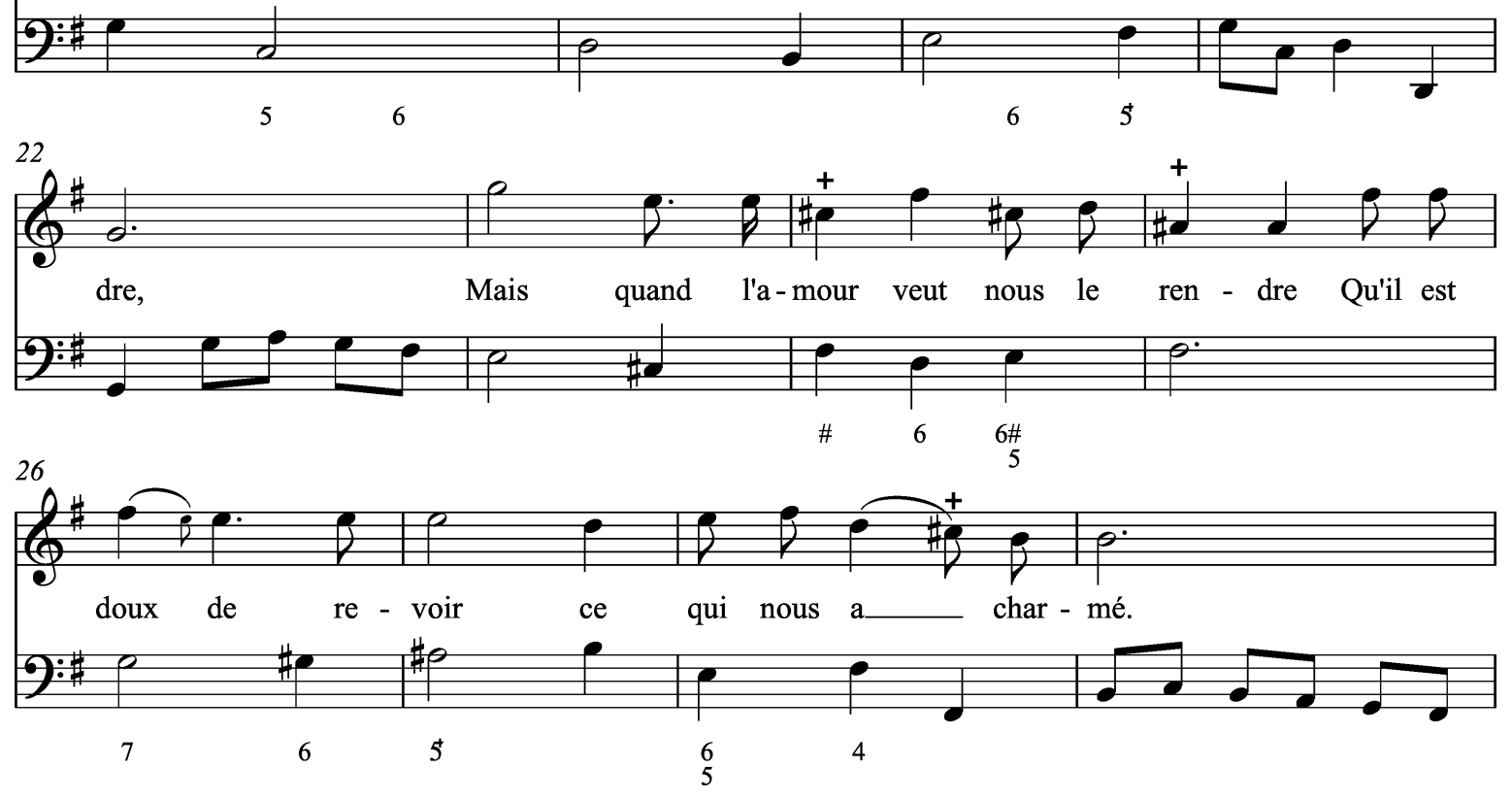

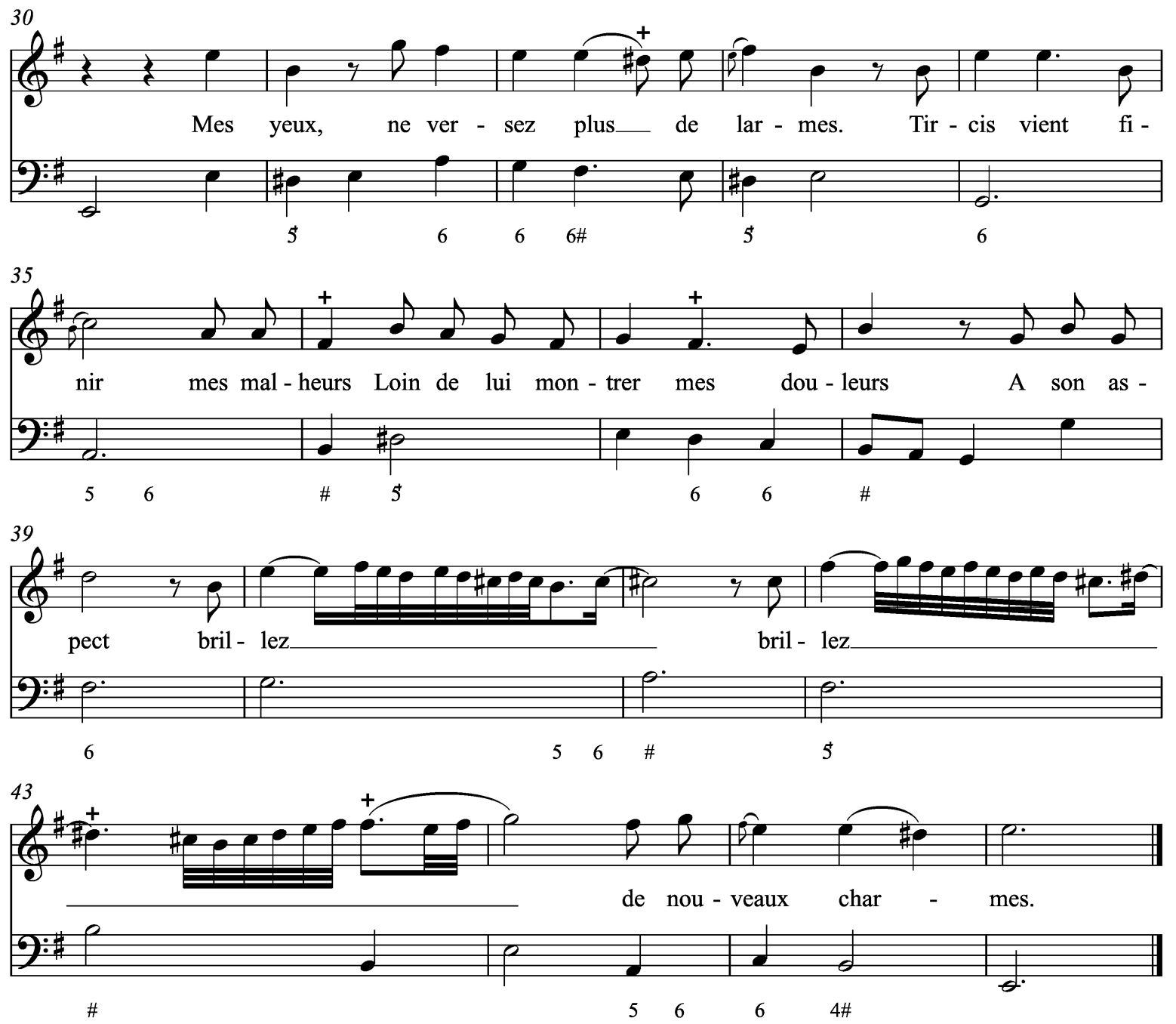


\section{3. Échos indiscrets, taisez-vous}

Air sérieux

[Voix]

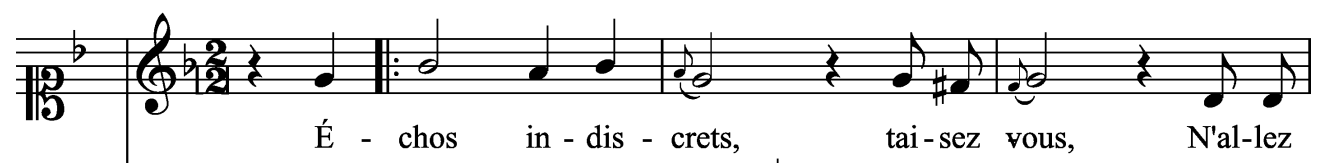

[Basse continue]
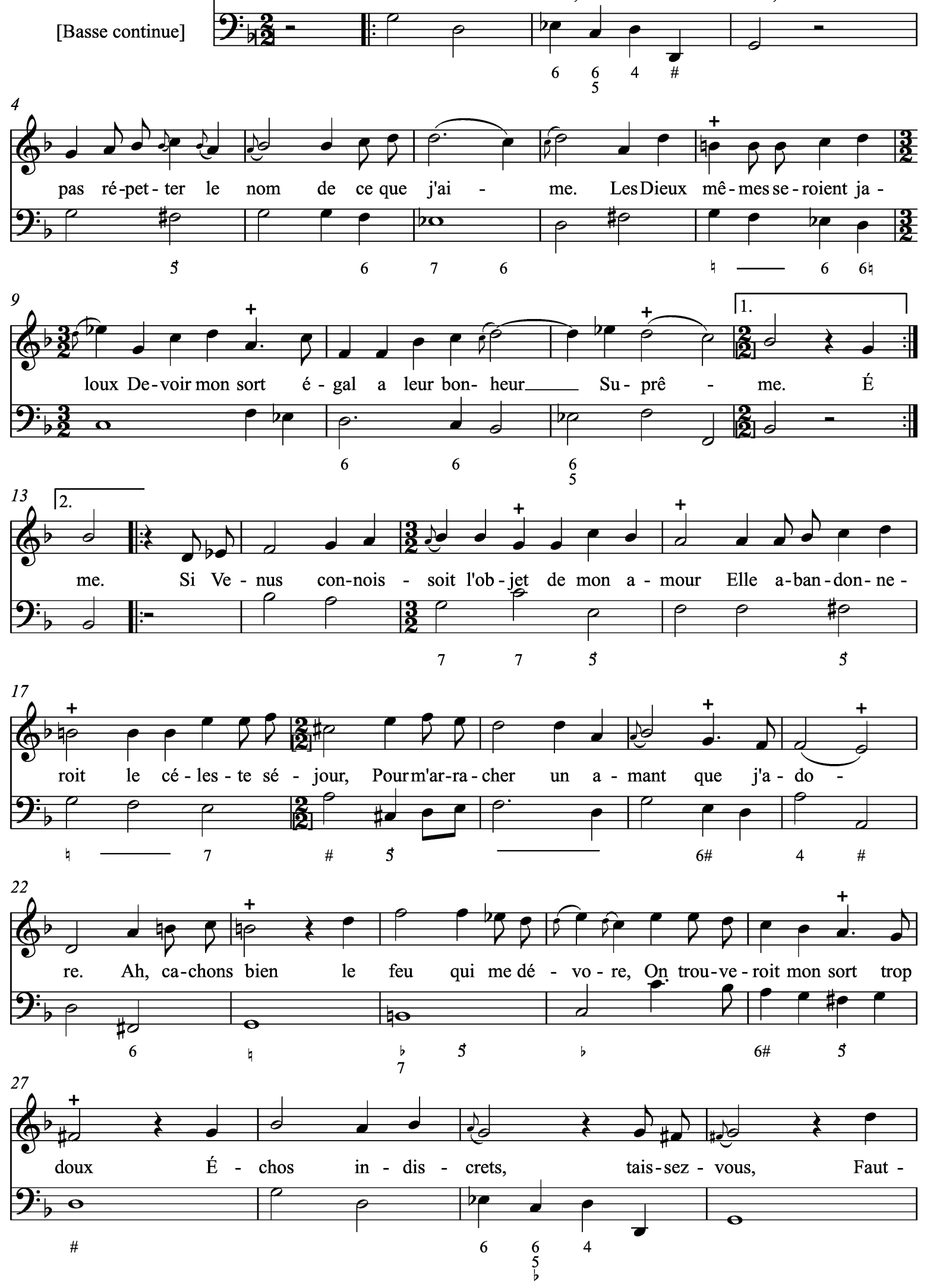


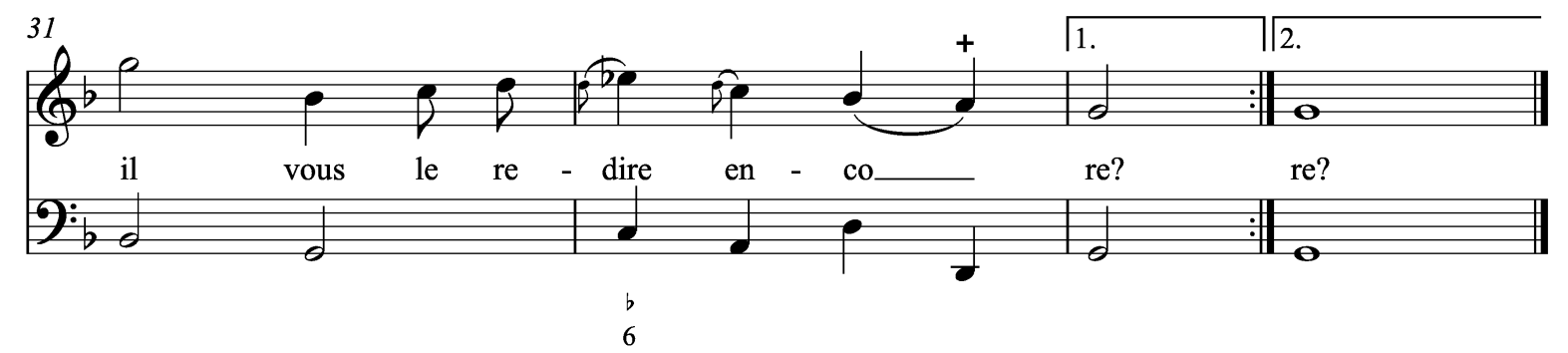




\section{Funeste ennemy de la paix}

Air sérieux

[Voix]

[Basse continue]

$\mathrm{Fu}$ - neste en-ne - my de la paix, $\mathrm{Au}$ - theur de mes
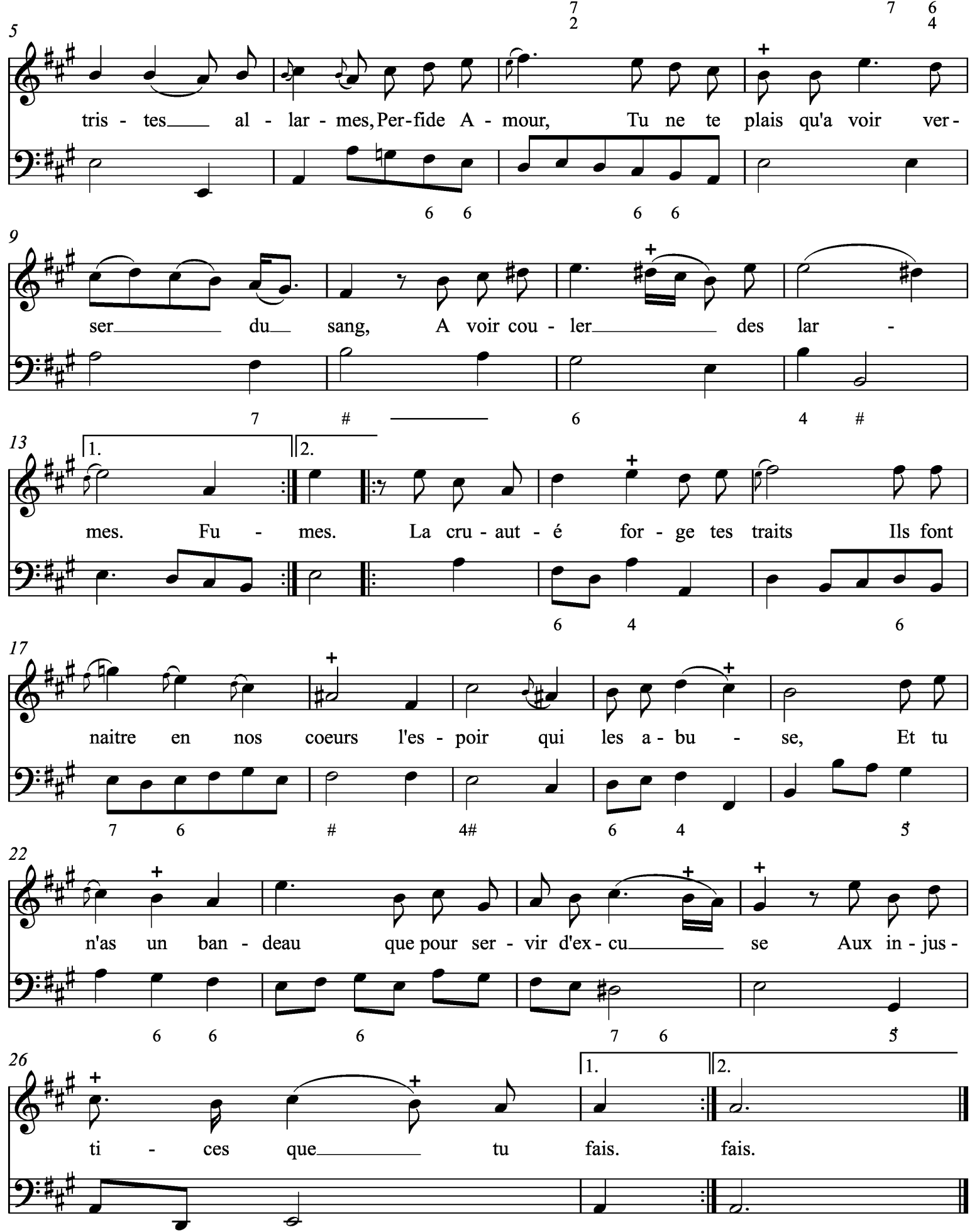


\section{Amans constans}

Air à boire
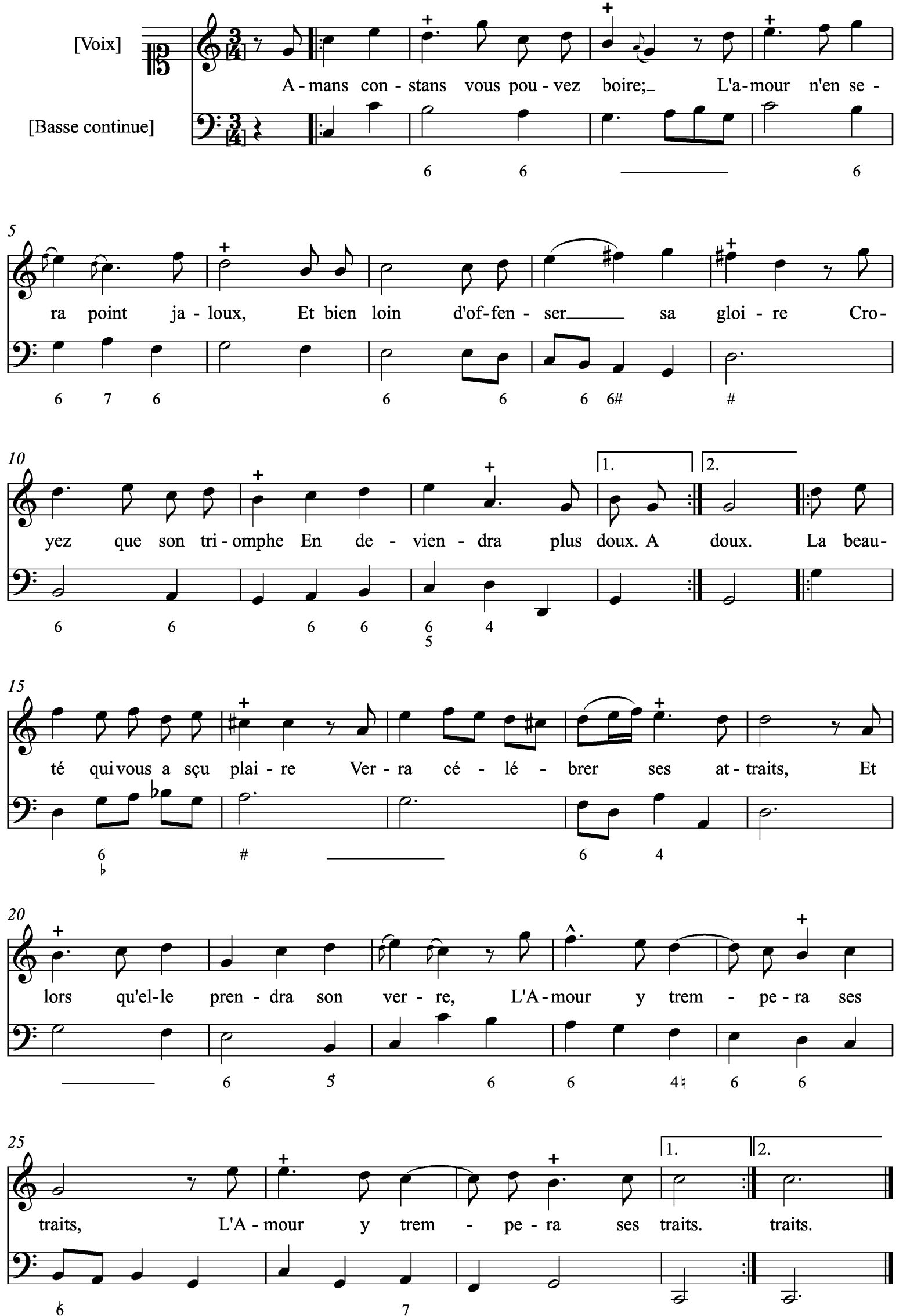


\section{Ruisseaux suspendez vôtre cours}

Air sérieux

[Voix]

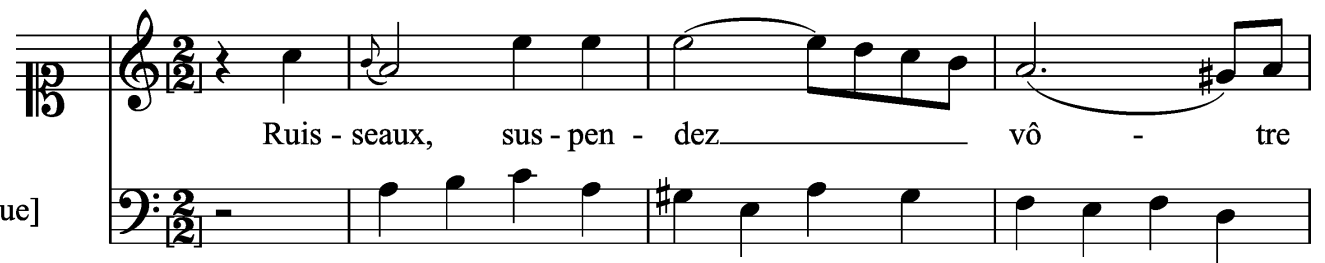

6 [\#]

6

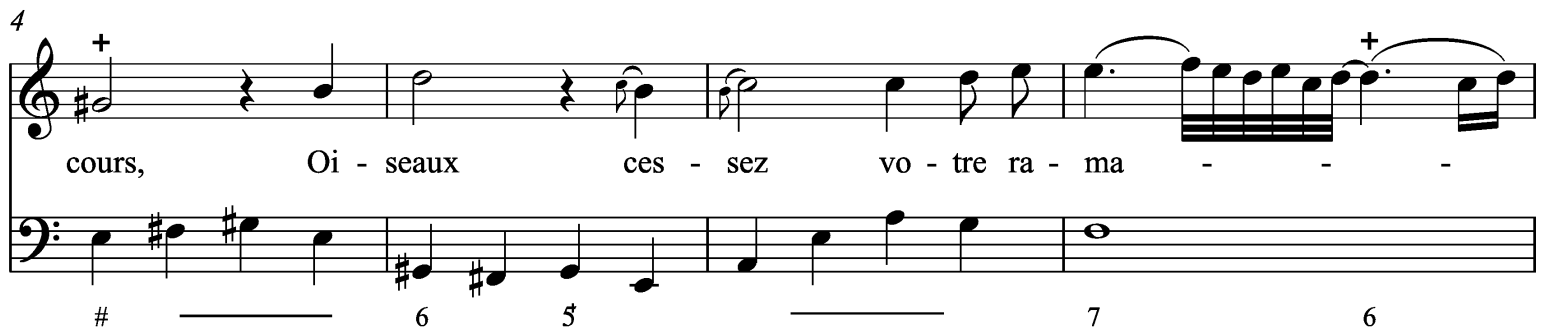

8
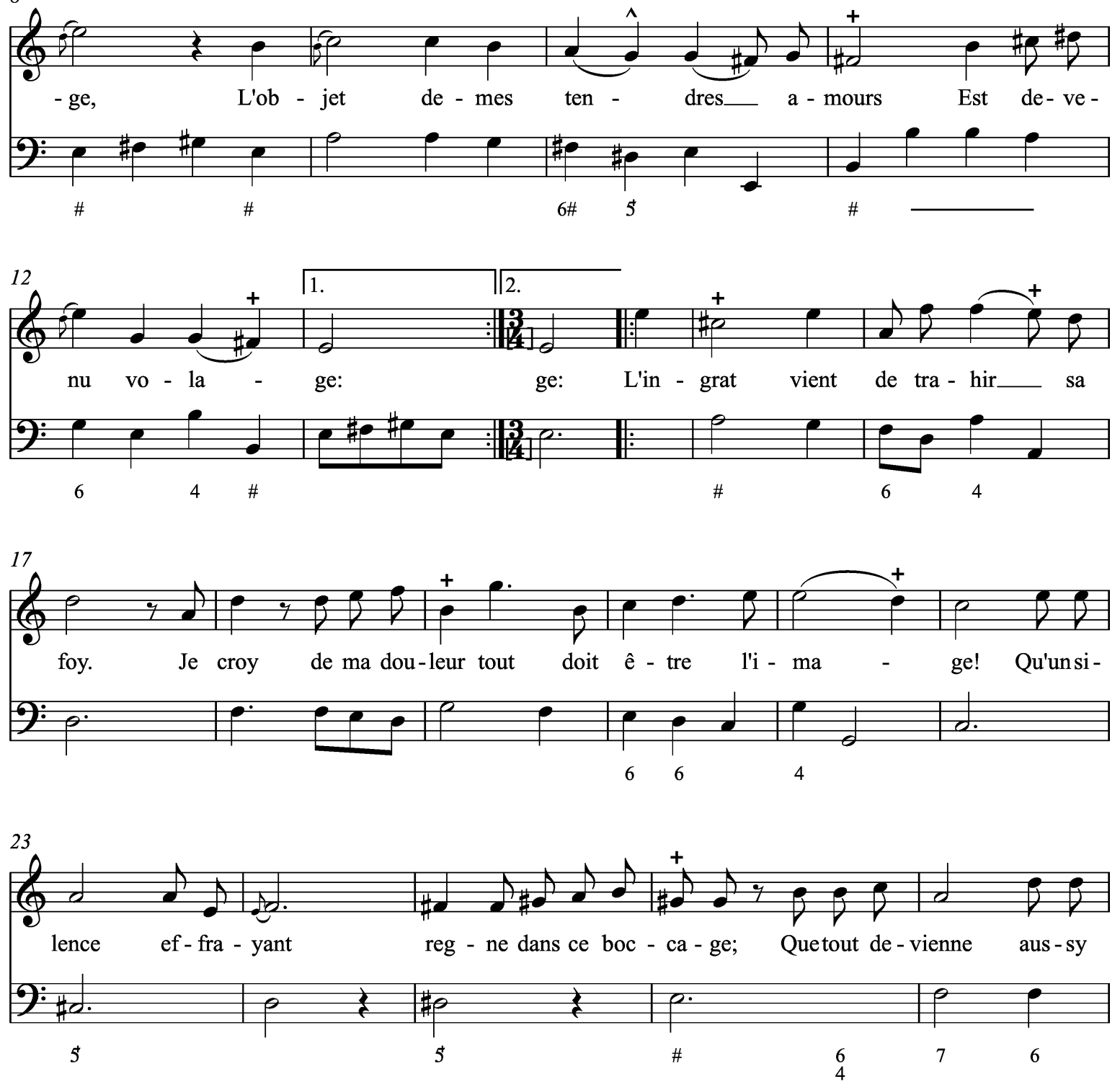

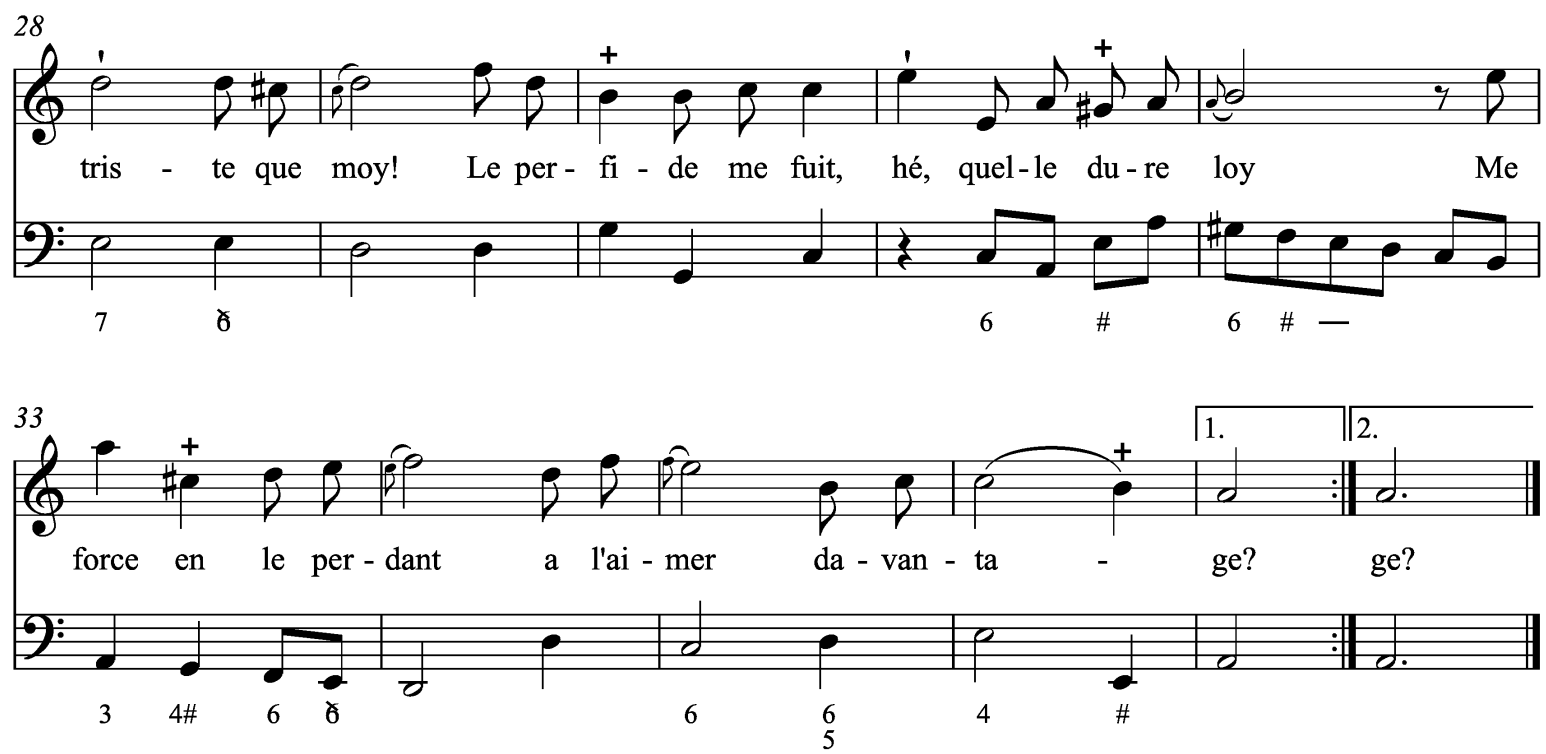


\section{De la philosophie}

Récit de basse Taille

[Voix]

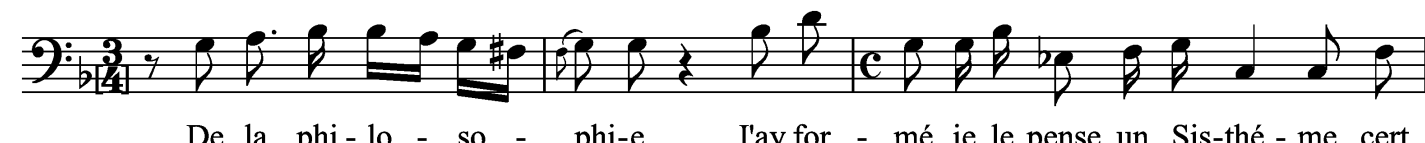

De la phi - lo - so - phi-e J'ay for - mé je le pense un Sis-thé - me cert

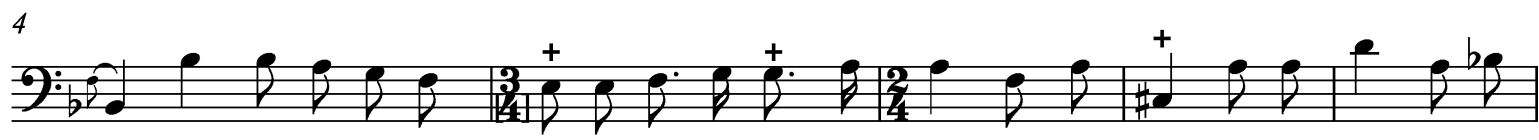

tain Et j'aypour le prou - ver à tout legenre hu - main Et Bac-chus et Bac-chus et Sil-

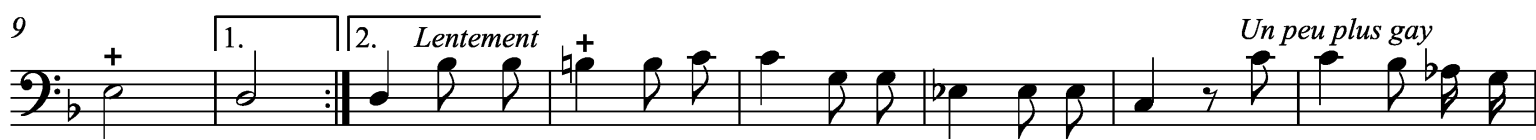

vi - e: e: Pour bra - ver du des - tin les bi - sea - res dé-crets Le vin sçaitmedon
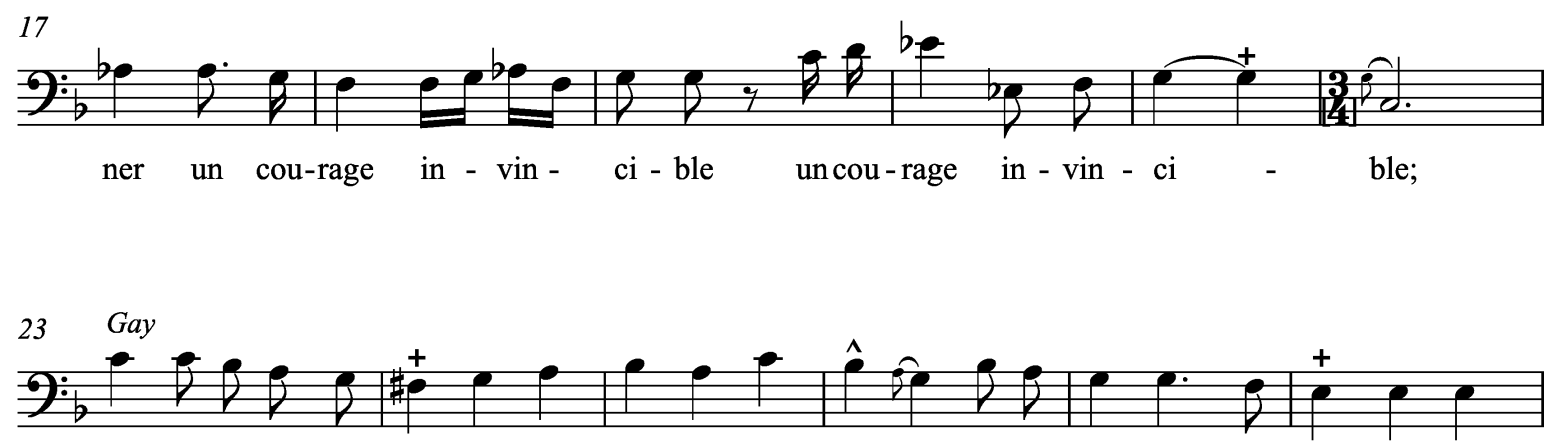

Et je ne con-nois point de plai - sir plus sen - si - ble Quede sui-vre l'A-mourquand il
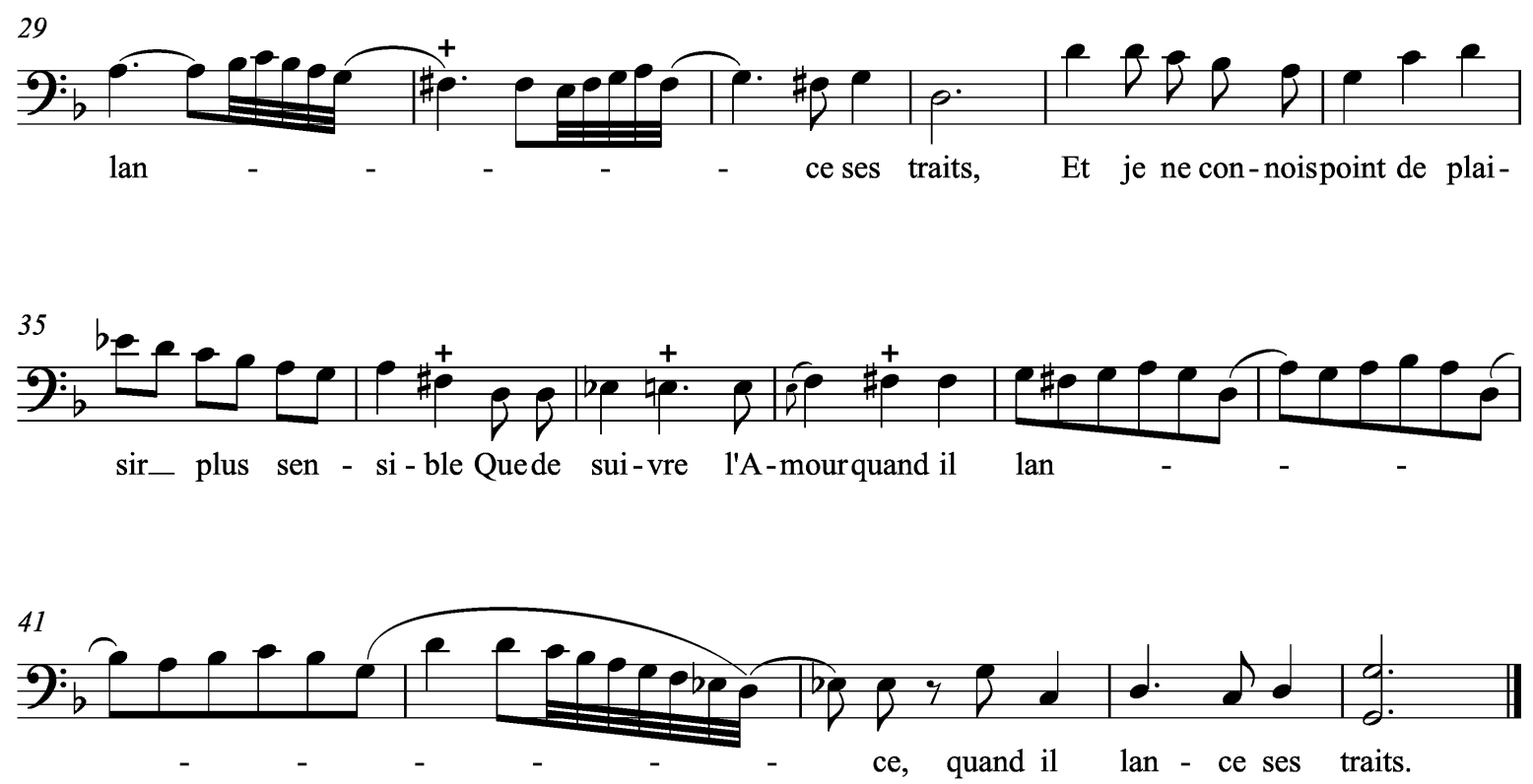


\section{Les charmes de l'indifférence}

Air sérieux

[Voix]

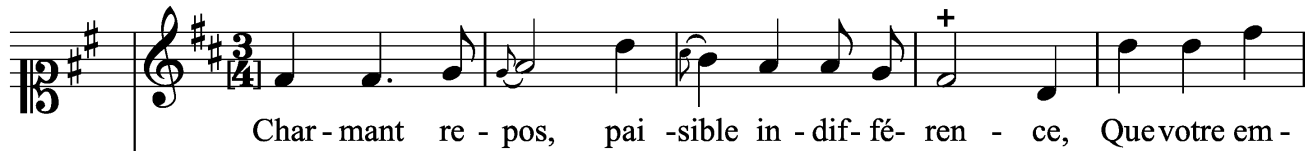

[Basse continue]
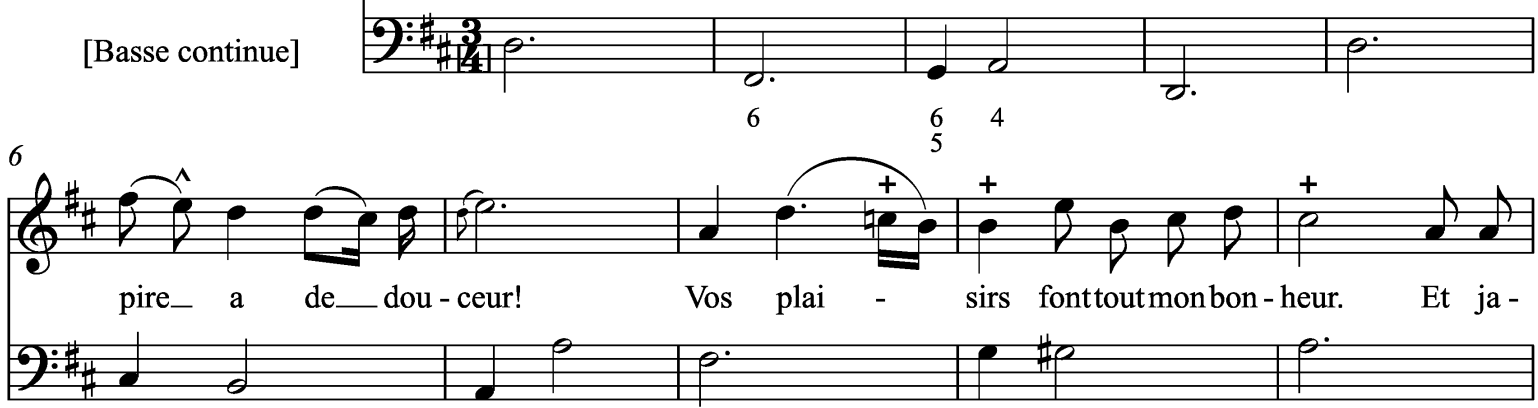

$\begin{array}{lll}6 & 5 & 5\end{array}$
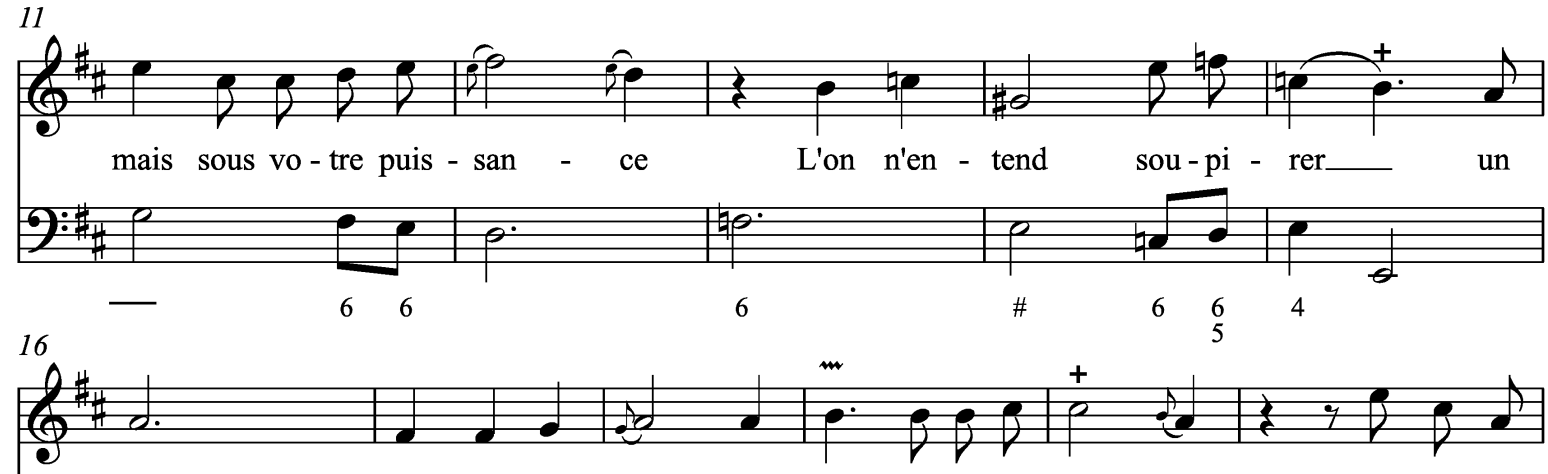

coeur, Char-mans re - pos, pai -sible in-dif-fé- ren - ce. Quevotre em-

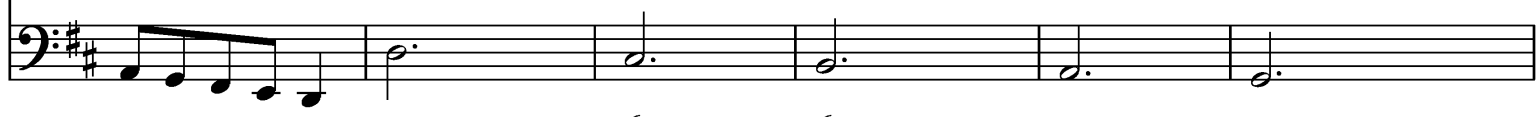

6

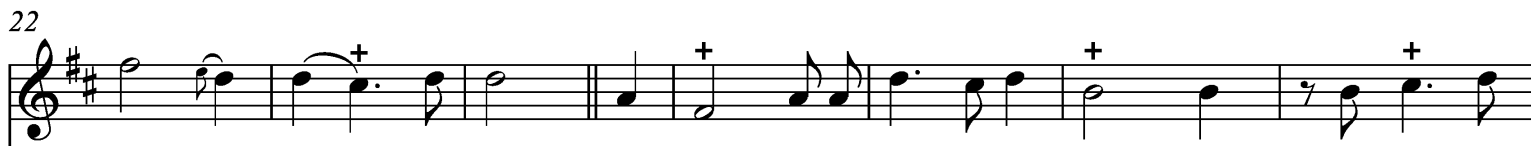

pire a de__ dou ceur! Des prez la ri - an - te ver - du - re, Les doux con-

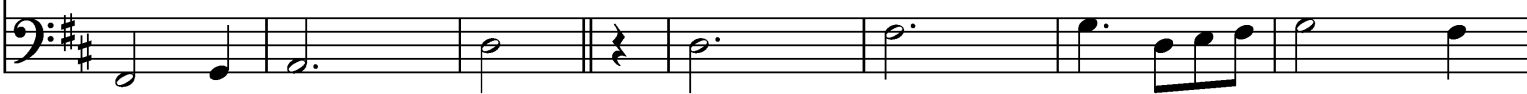
$\begin{array}{llll}6 & 6 & 4 & 5\end{array}$
6
4
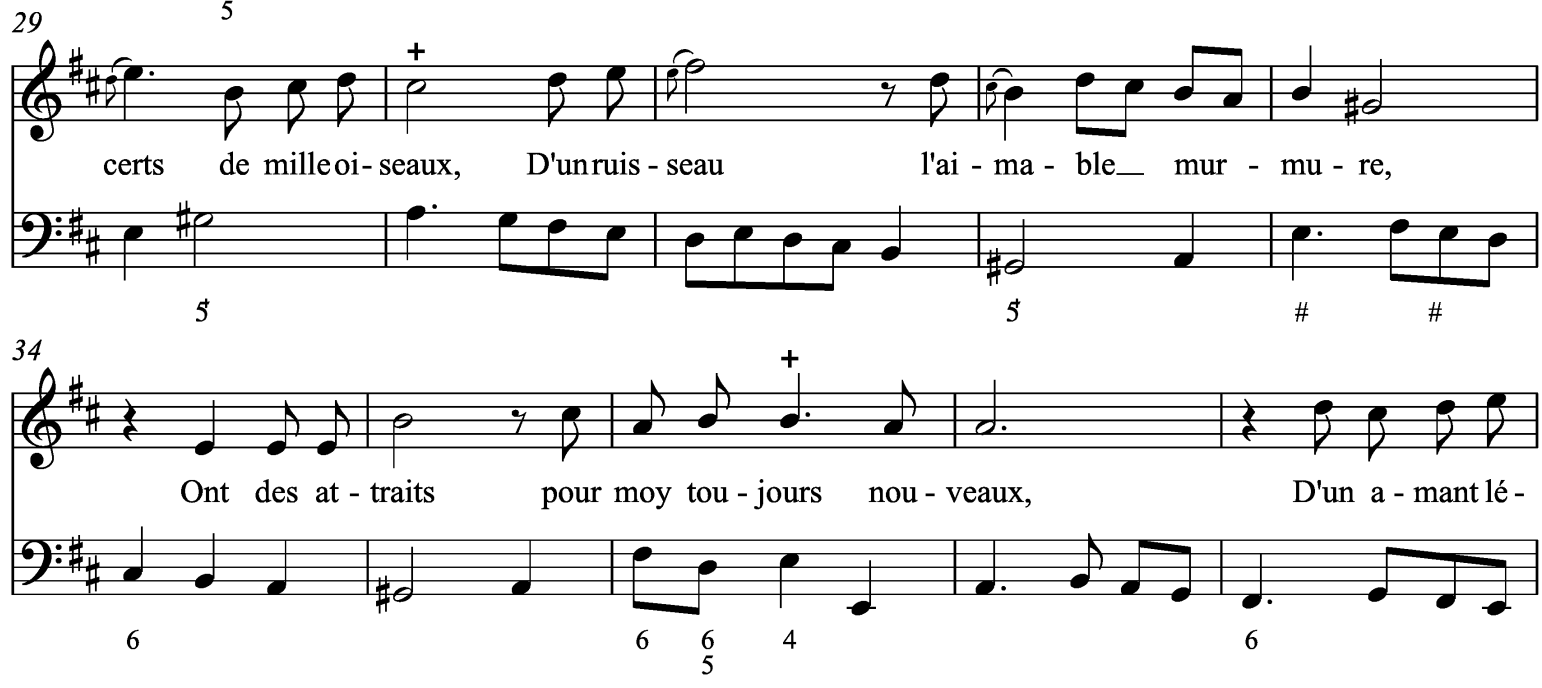

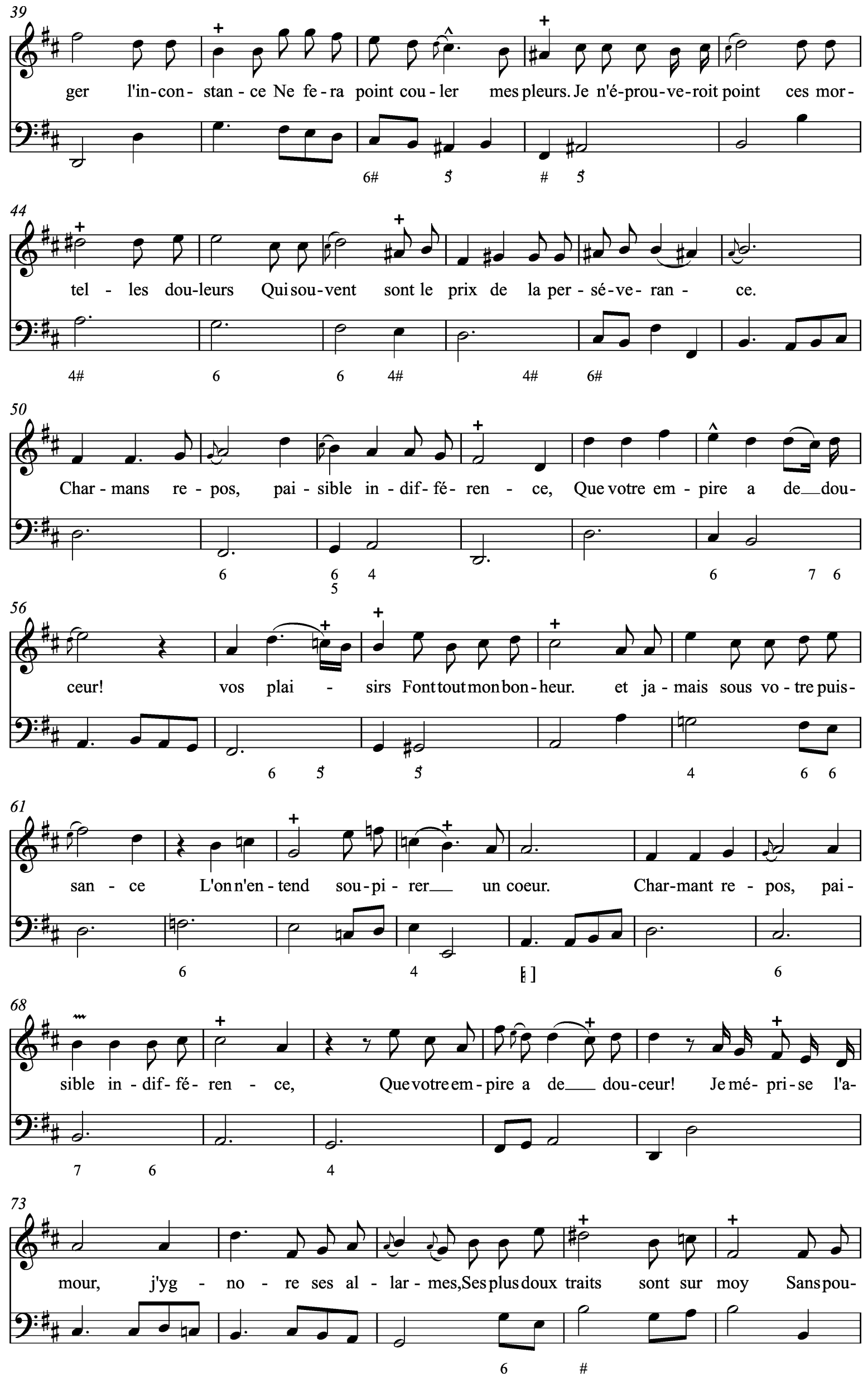

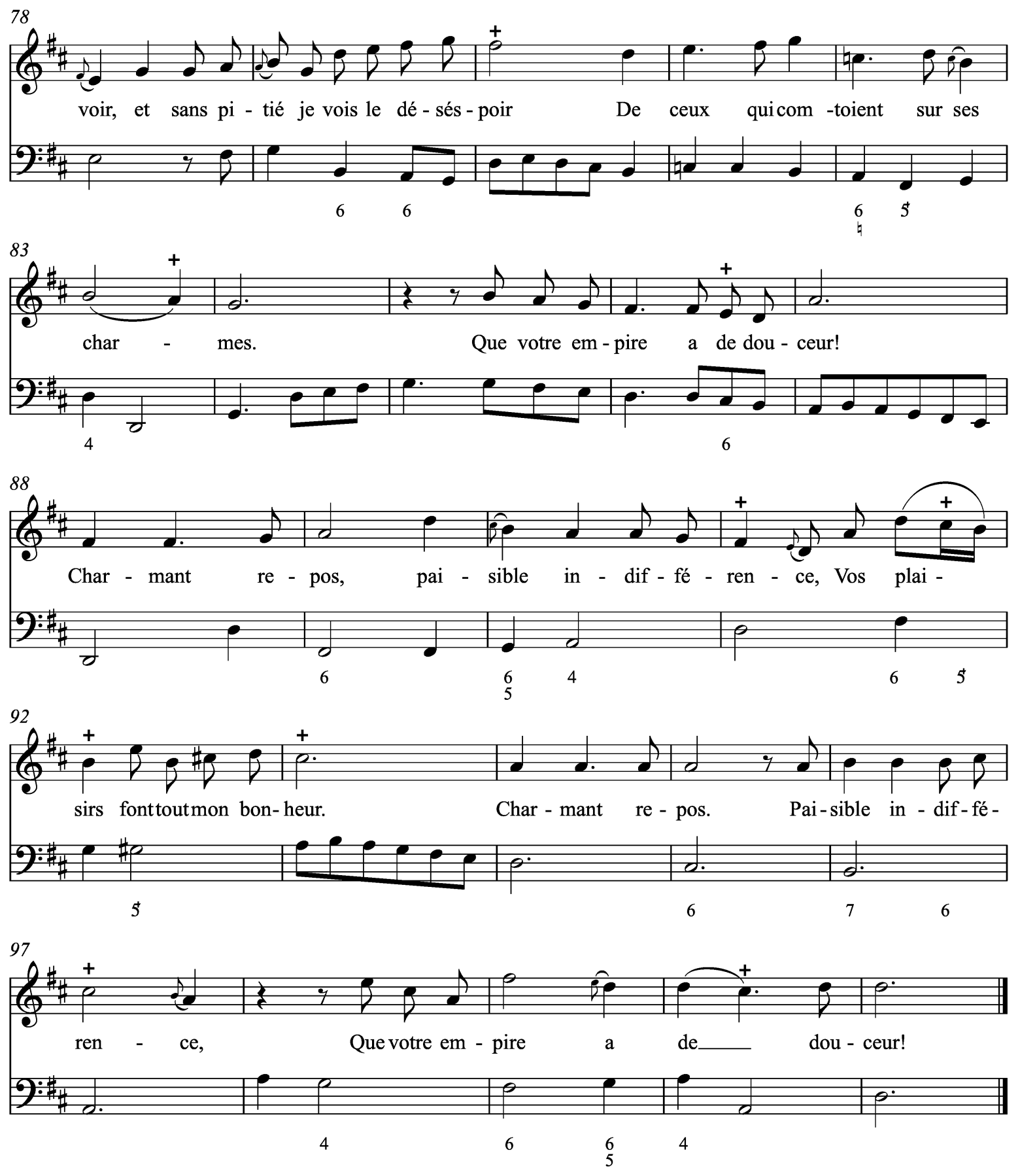


\section{Mon cher troupeau}

Brunette
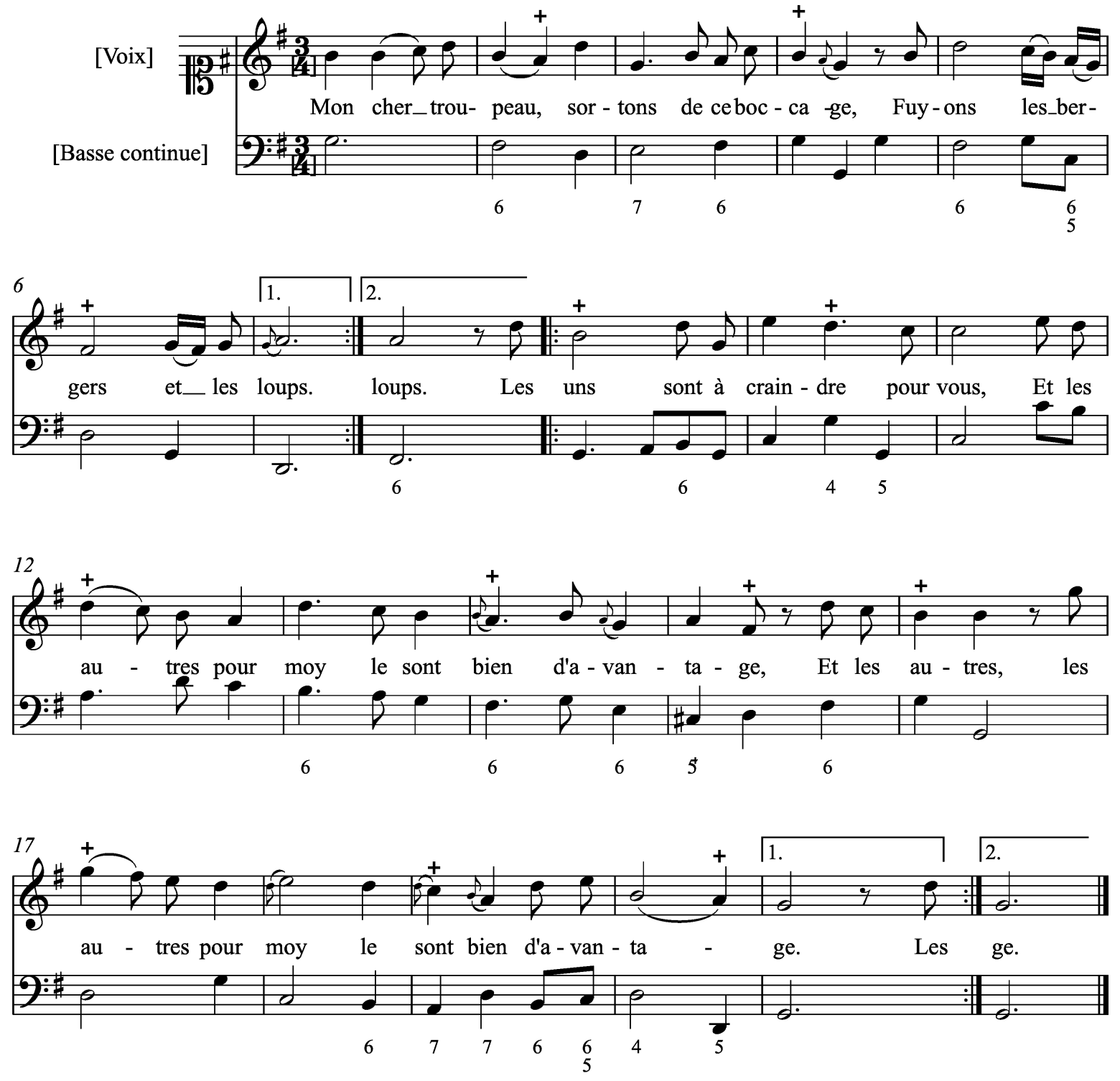


\section{Lors que l'on boit à mes amours}

Air à boire
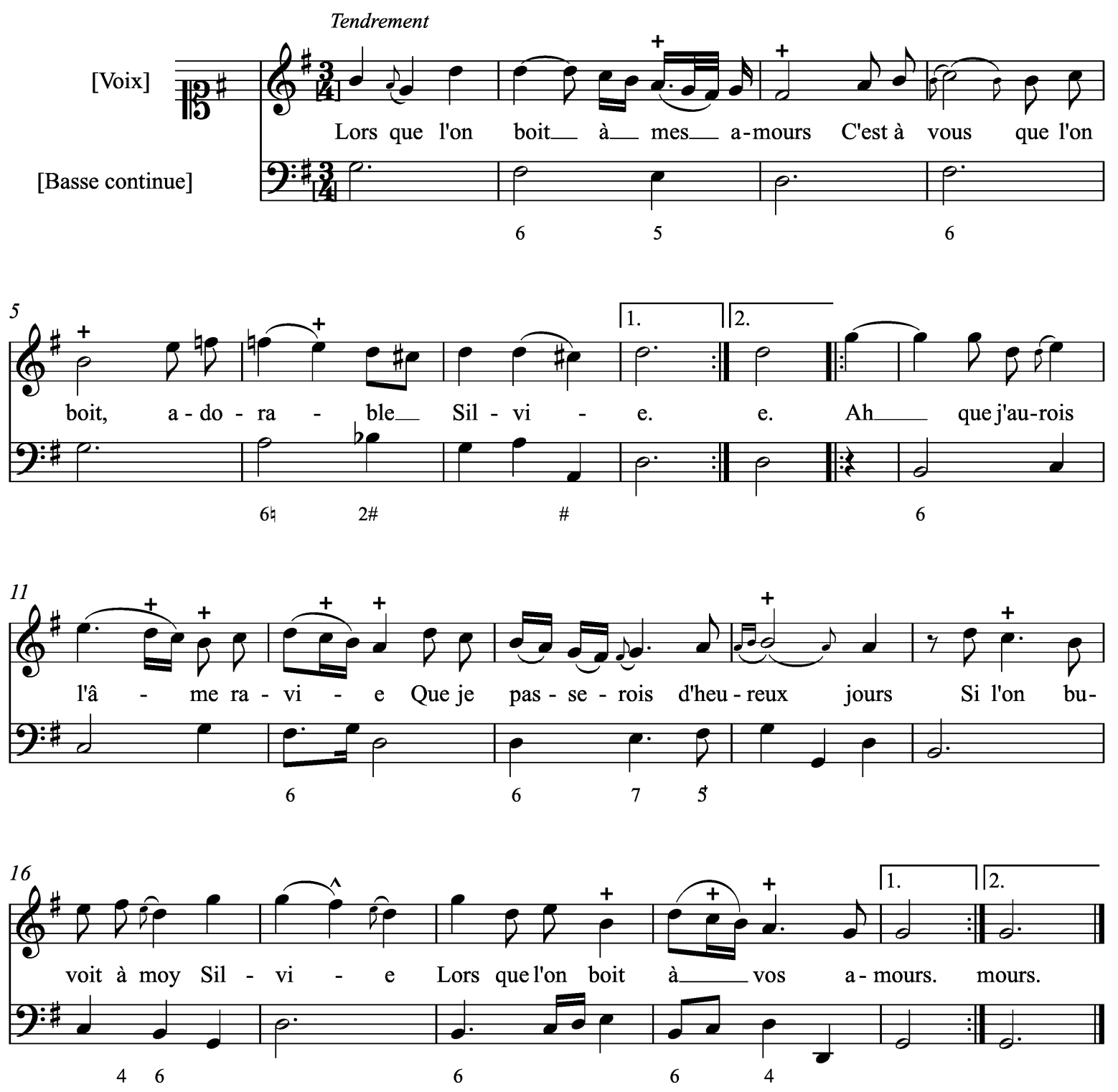


\section{Que Tircis est charmant}

Air sérieux

[Voix]

Tendrement

[Basse continue]
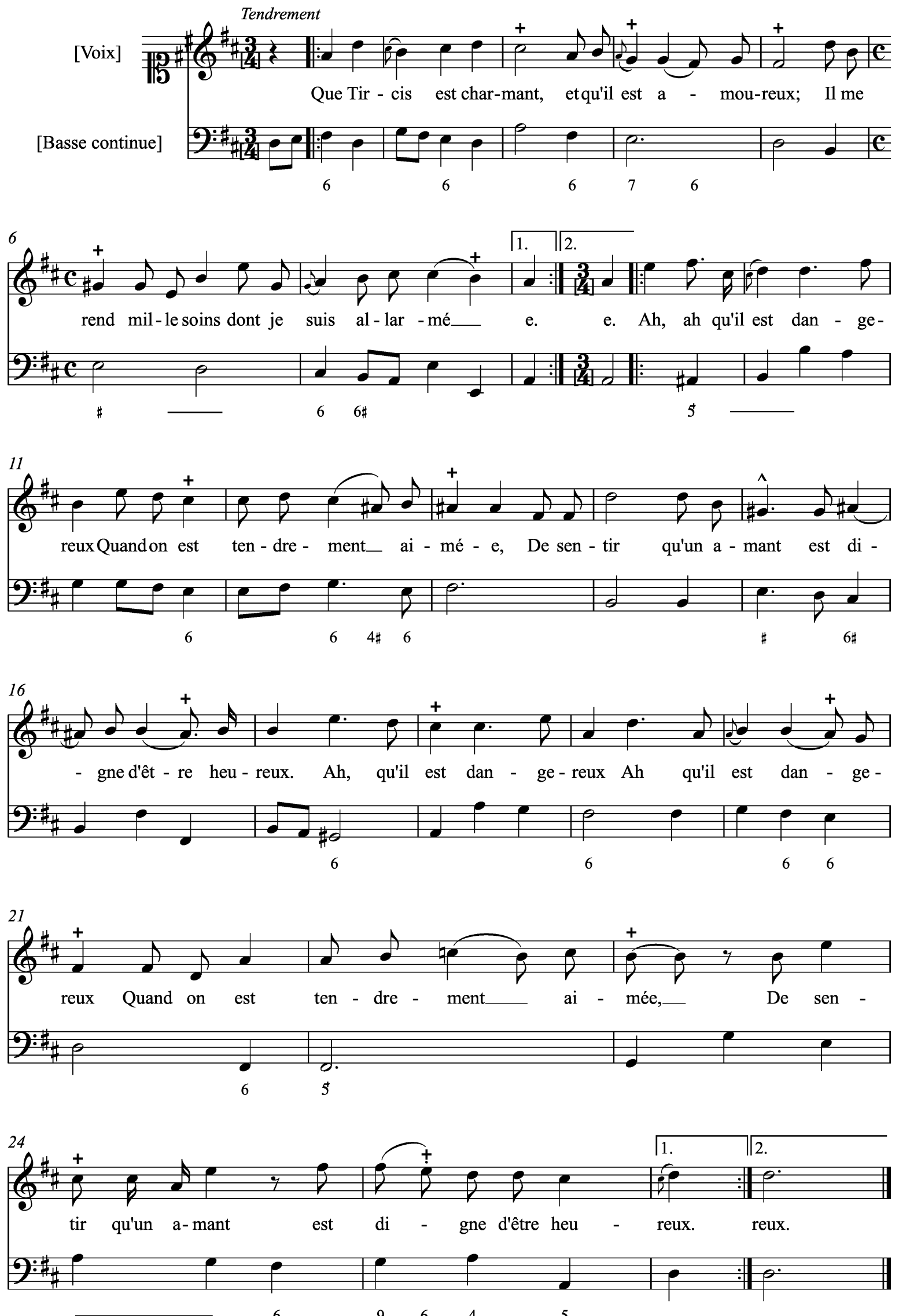


\section{Buvons Lucas}

Air à boire Duo

[Voix]

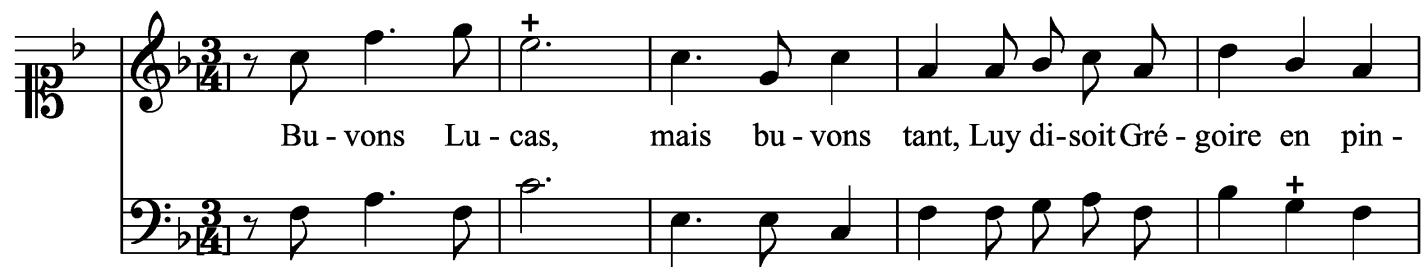

$\mathrm{Bu}$-vons $\mathrm{Lu}$ - cas, mais bu-vons tant, Luy di-soitGré-goire en pin -
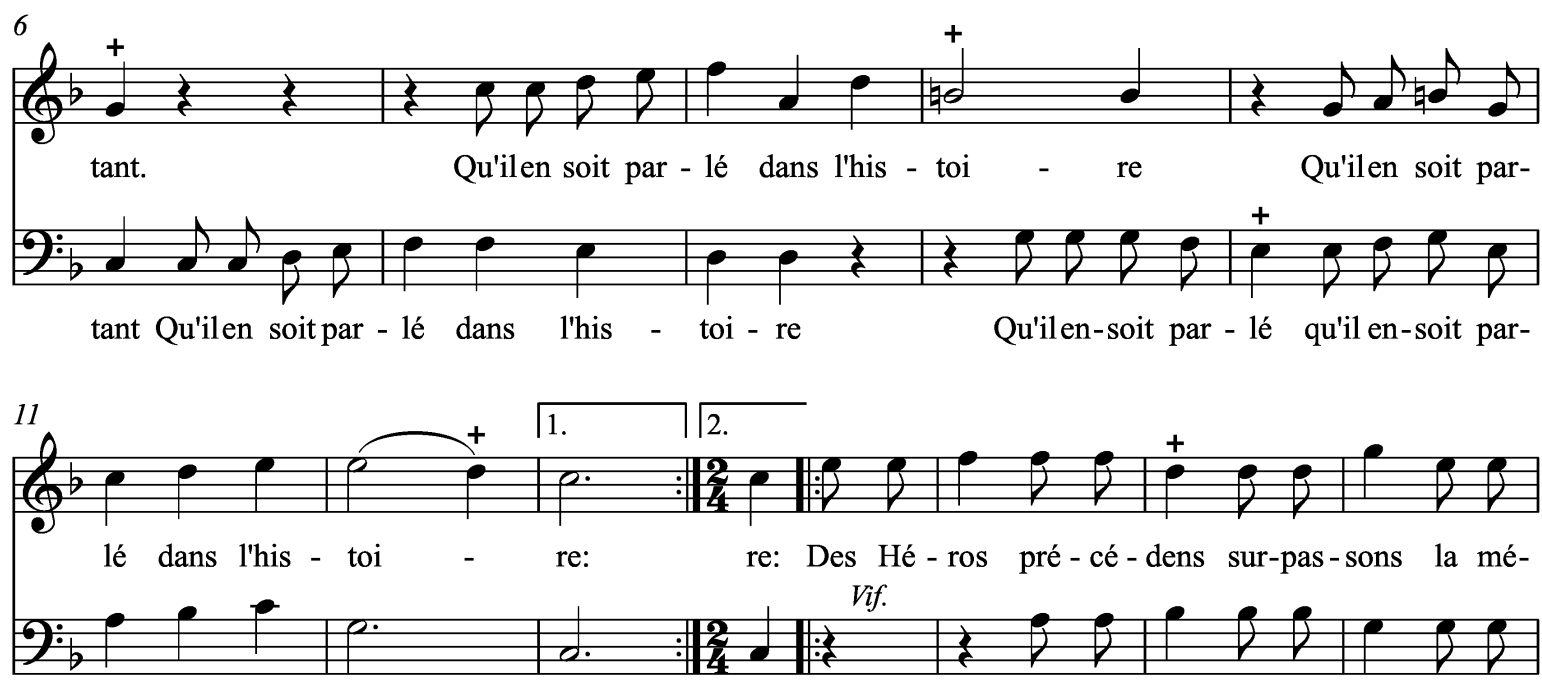

lé dans l'his - toi - re: re:

Des Hé - ros pré-cé - dens sur-pa-

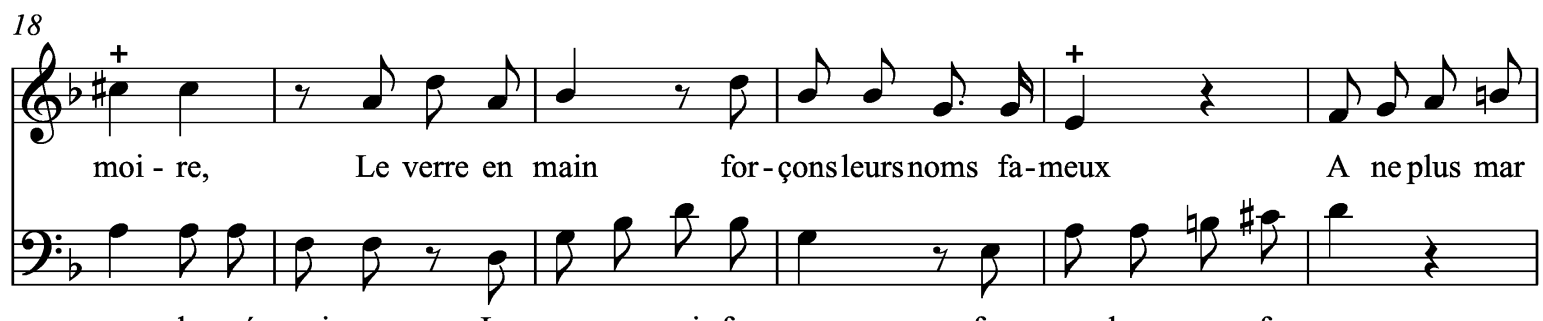

ssons la mé-moi - re, Le verre en mainfor-çons

for - çonsleursnoms fa-meux
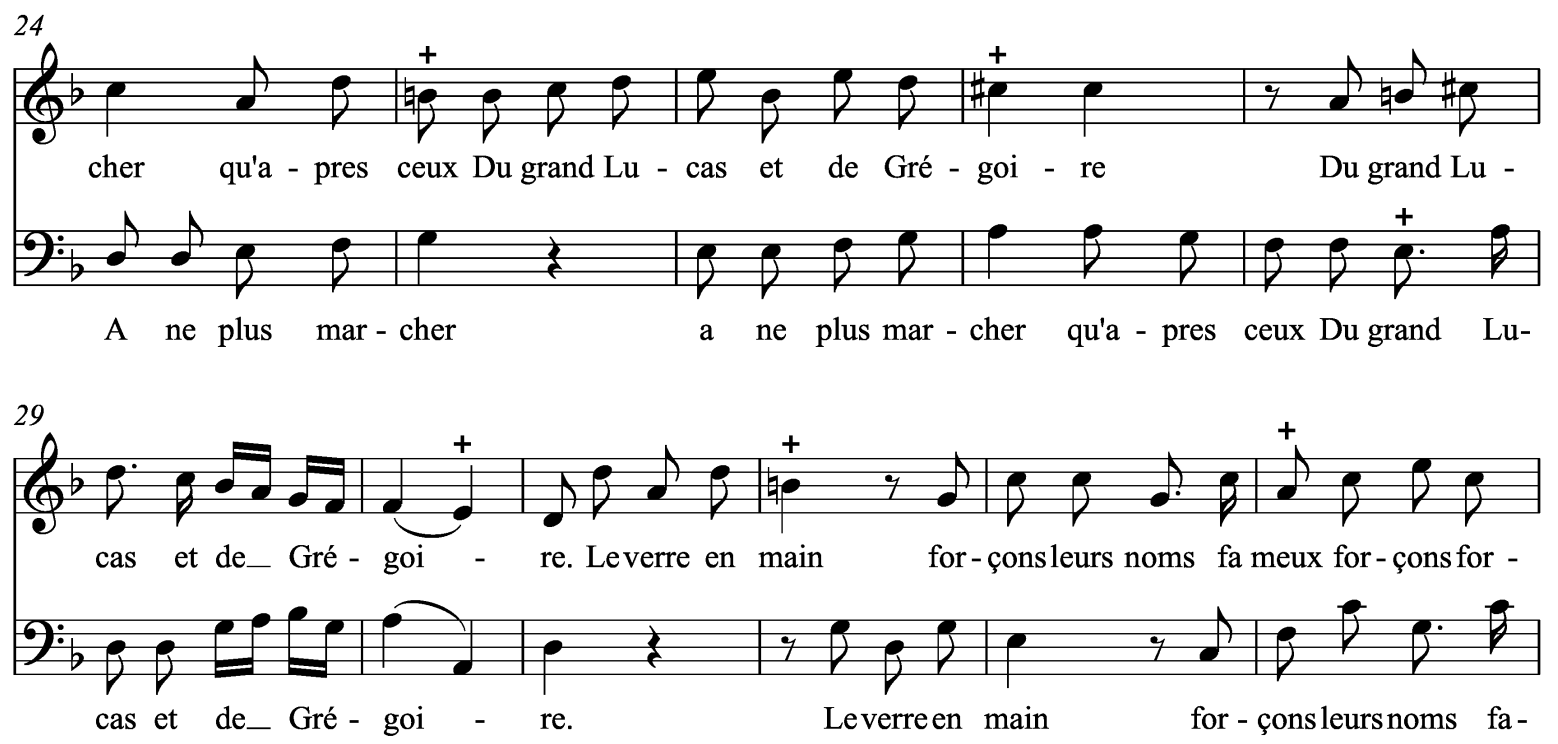


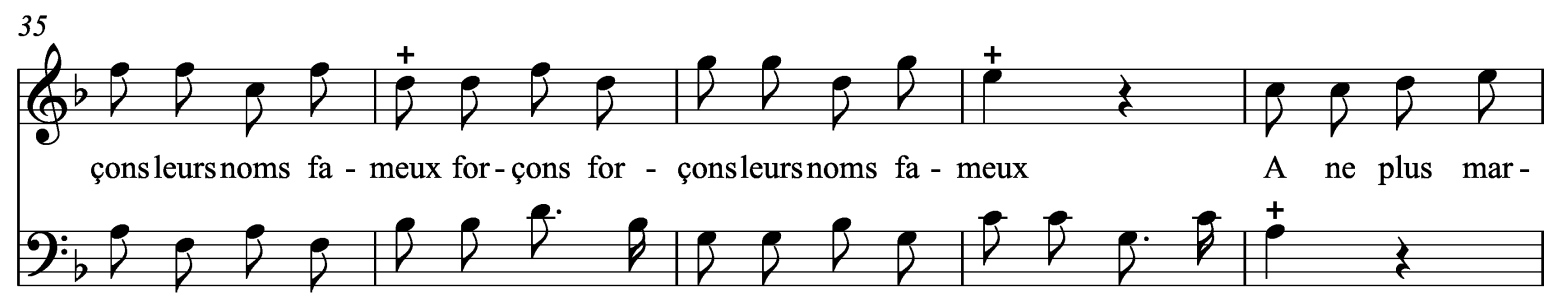

meux for-çons for - çonsleursnoms fa-meux for-çons for - çonsleursnoms fa-meux
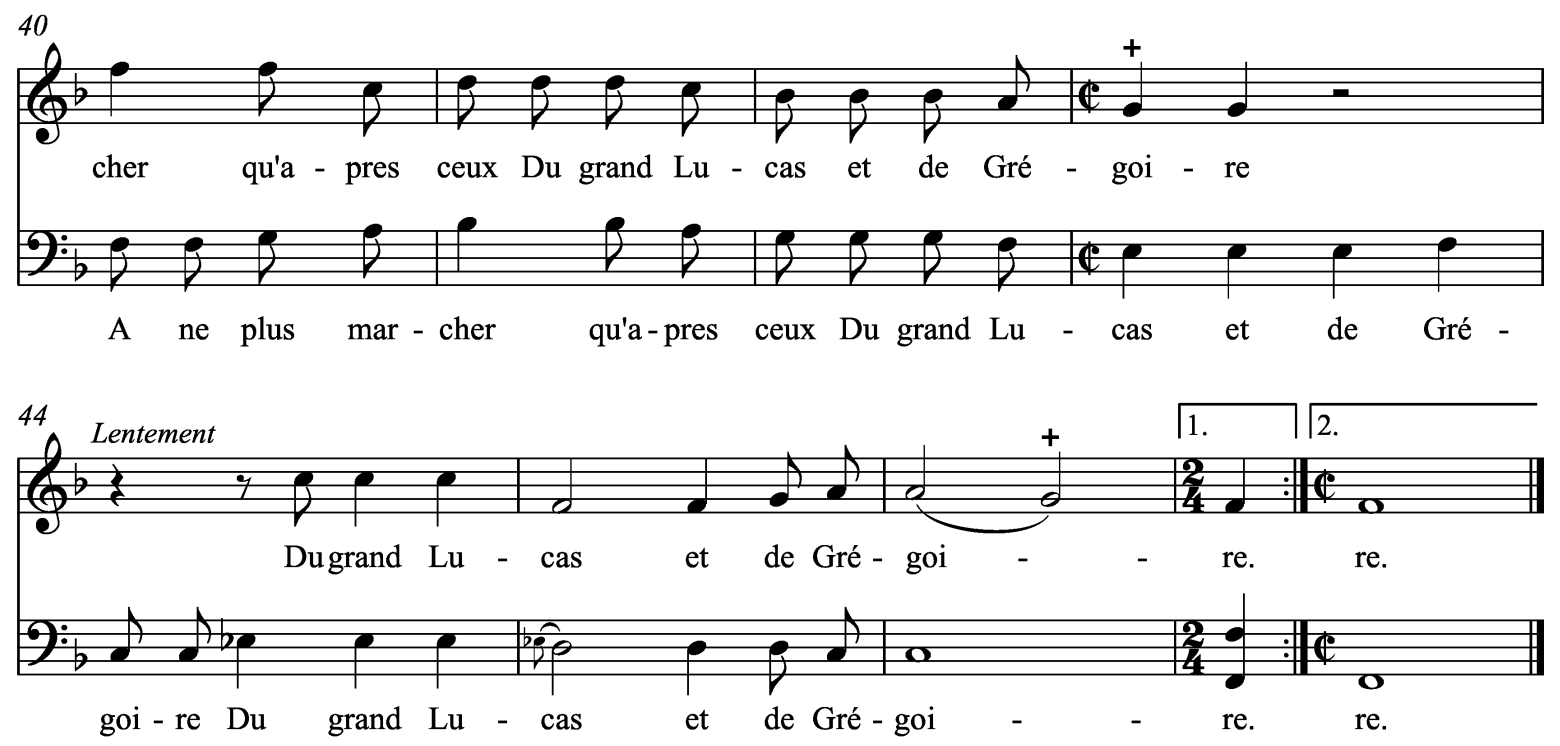


\section{Apres m'avoir formé les plus aimables chaines}

Air sérieux

[Voix]

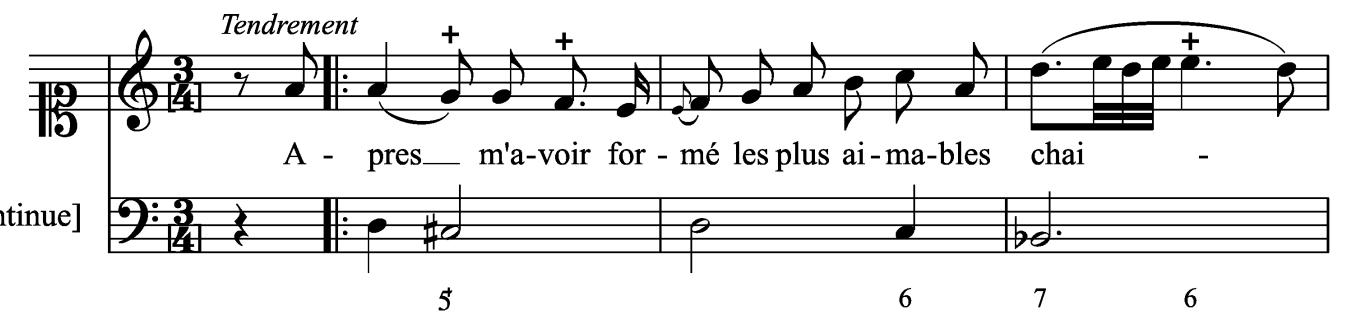

[Basse continue]
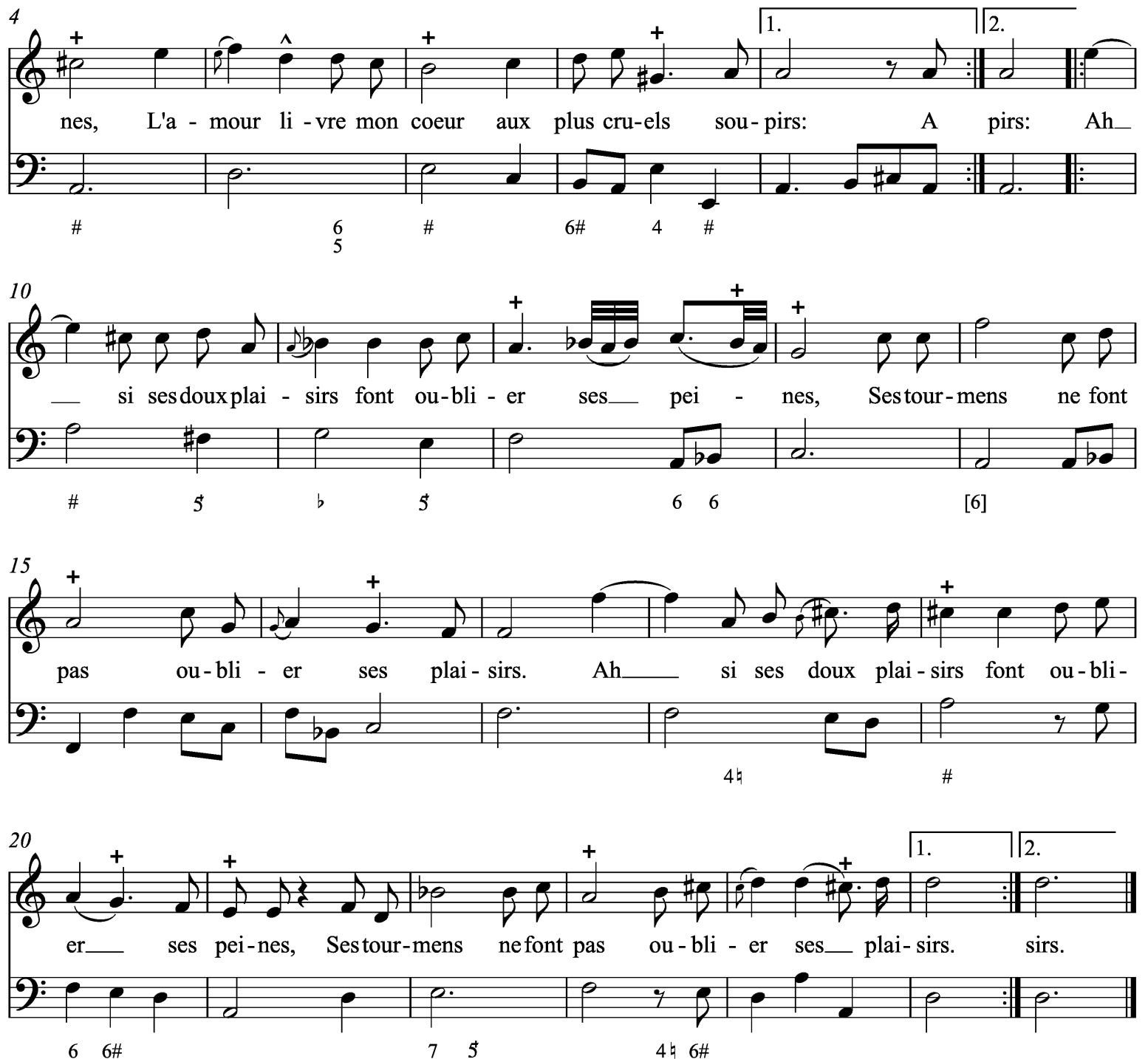


\section{Sombres lieux, obscures forrets}

Air sérieux
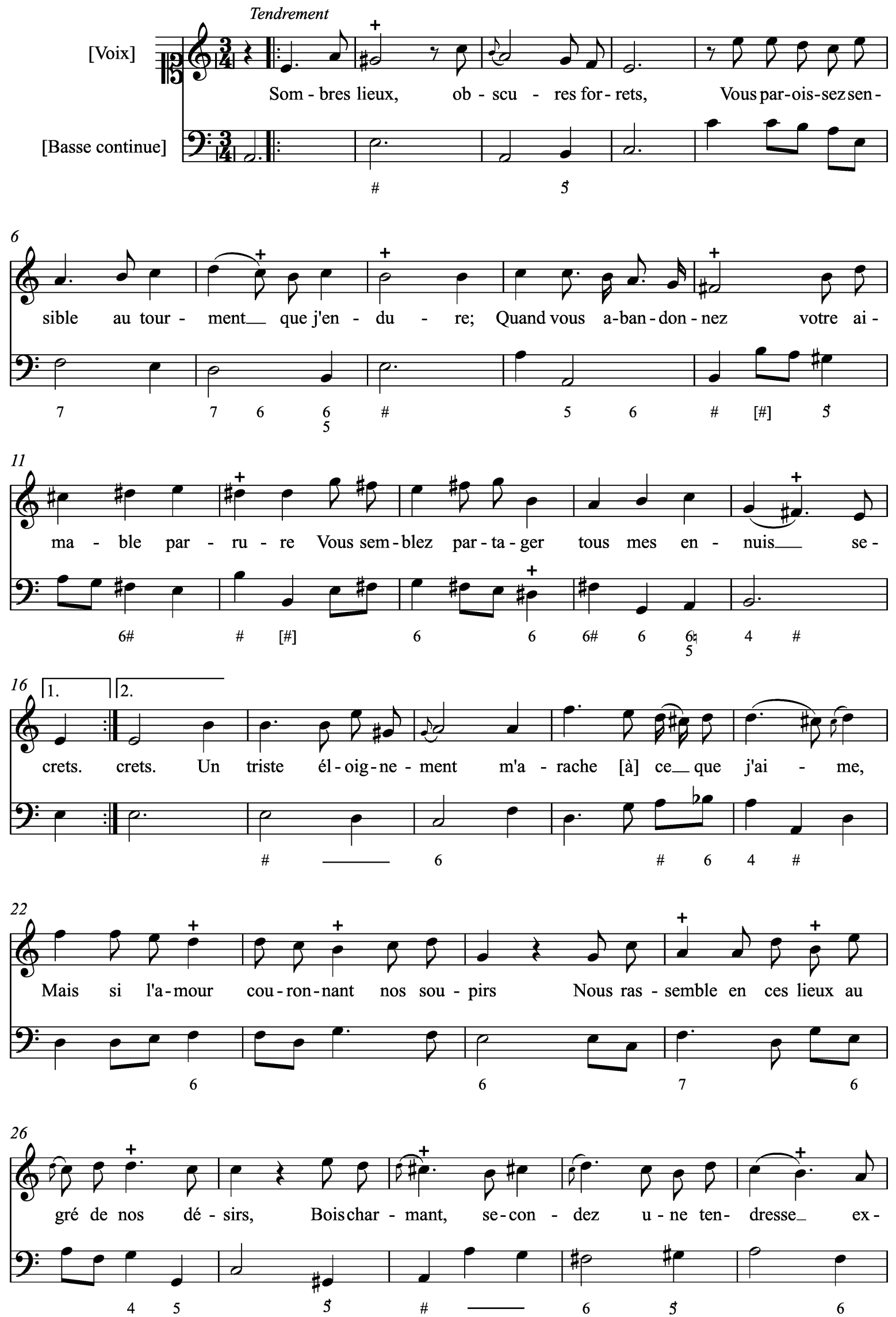

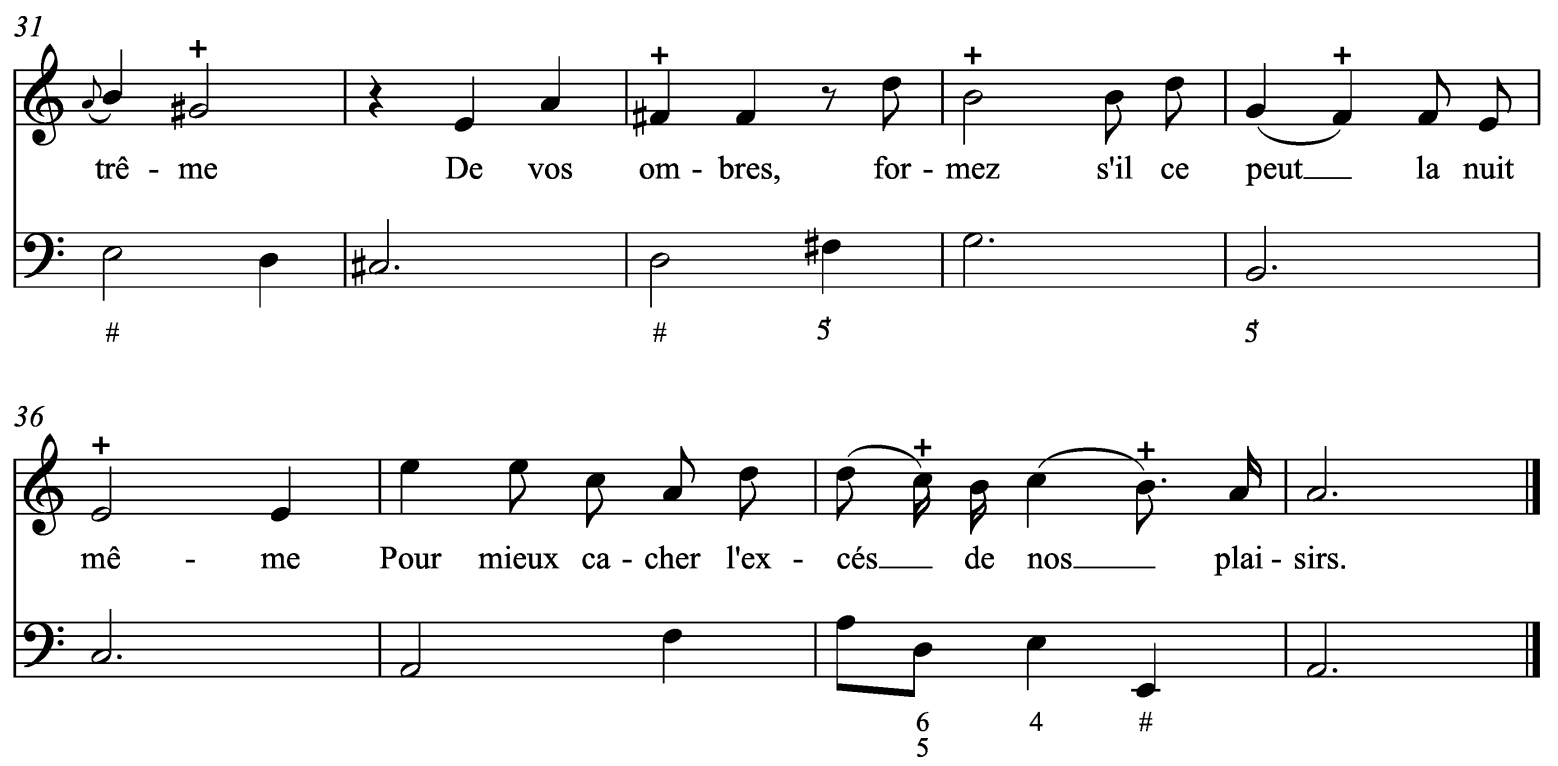


\section{Scène Pastorale}

[Basse continue]
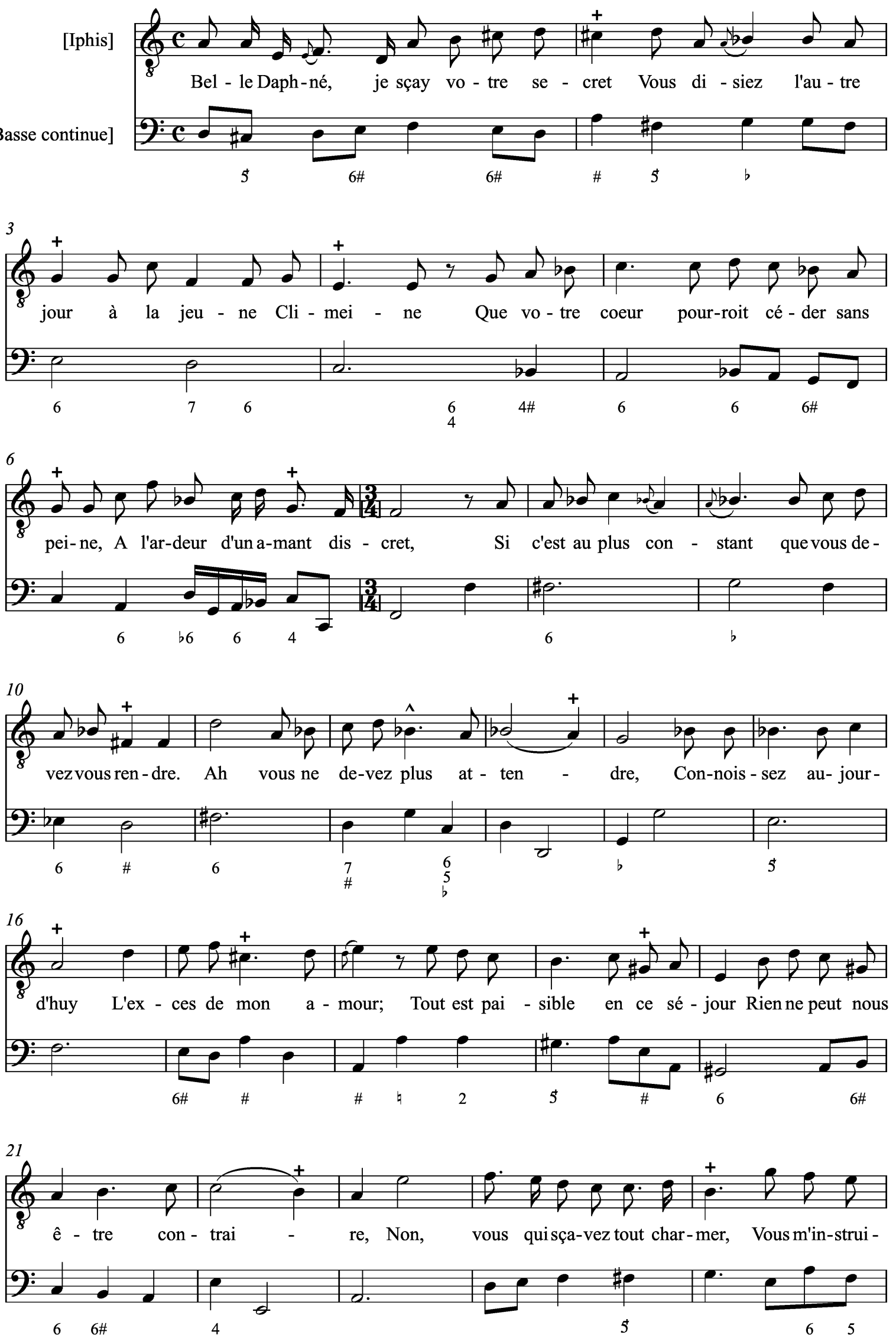

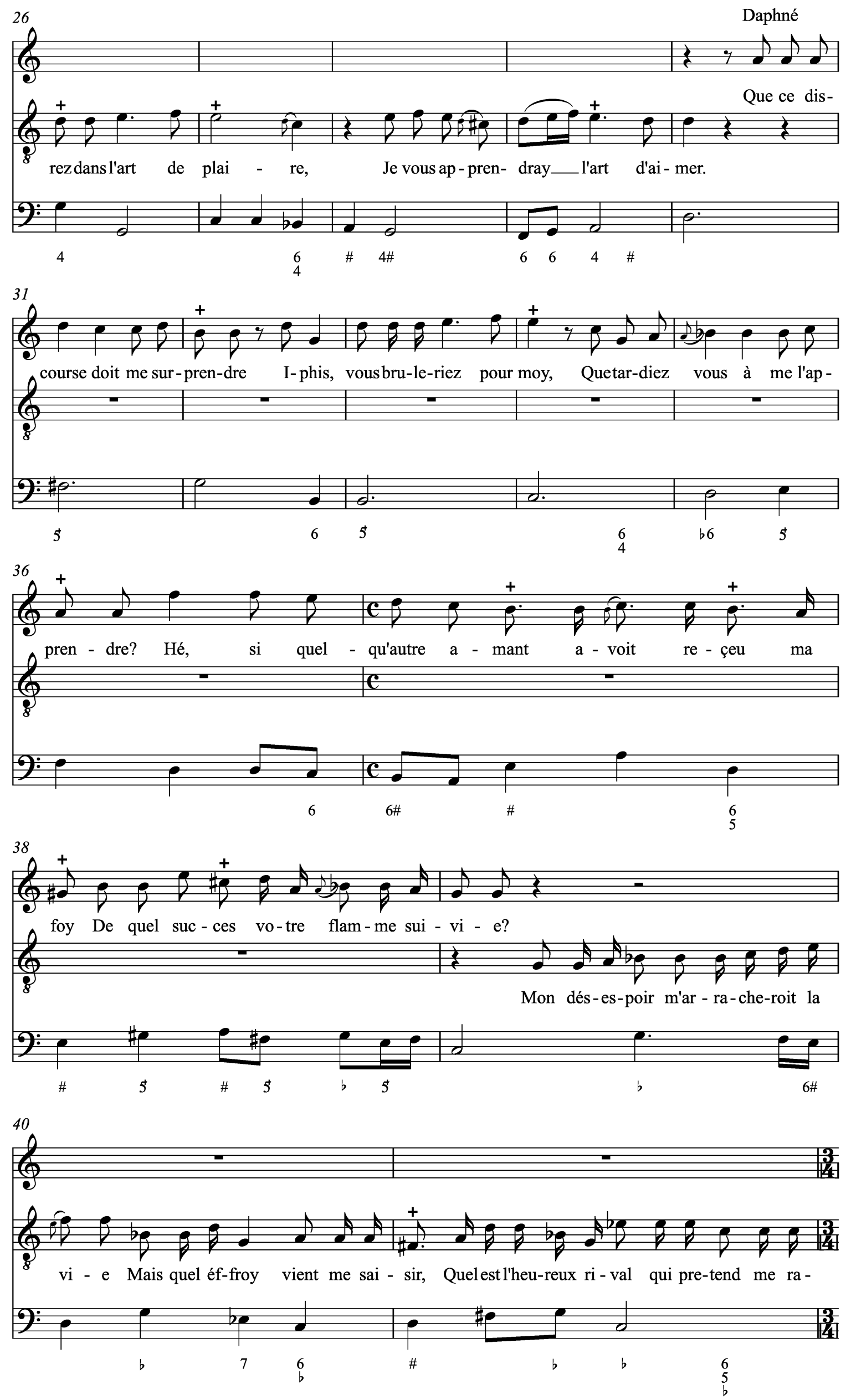

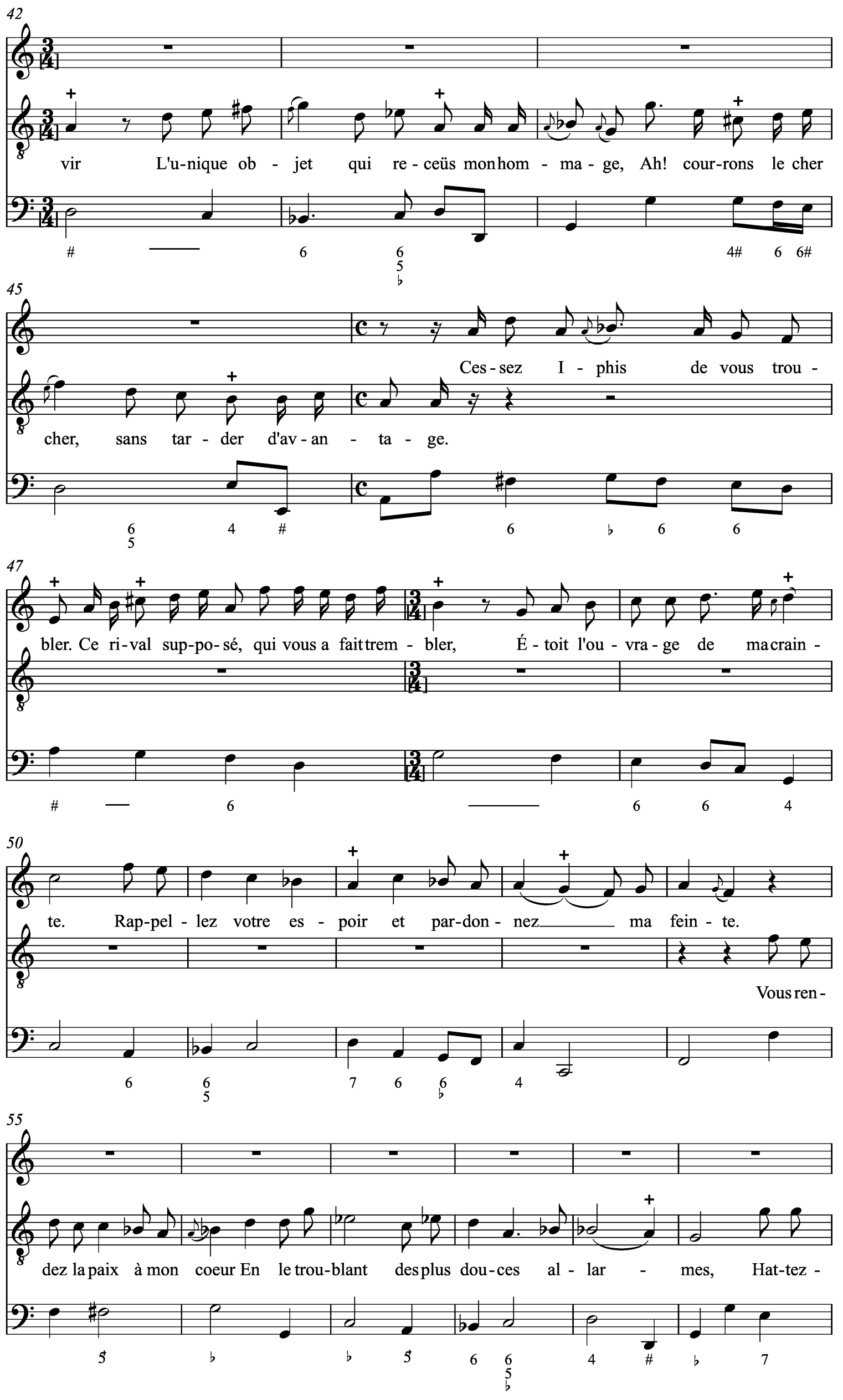

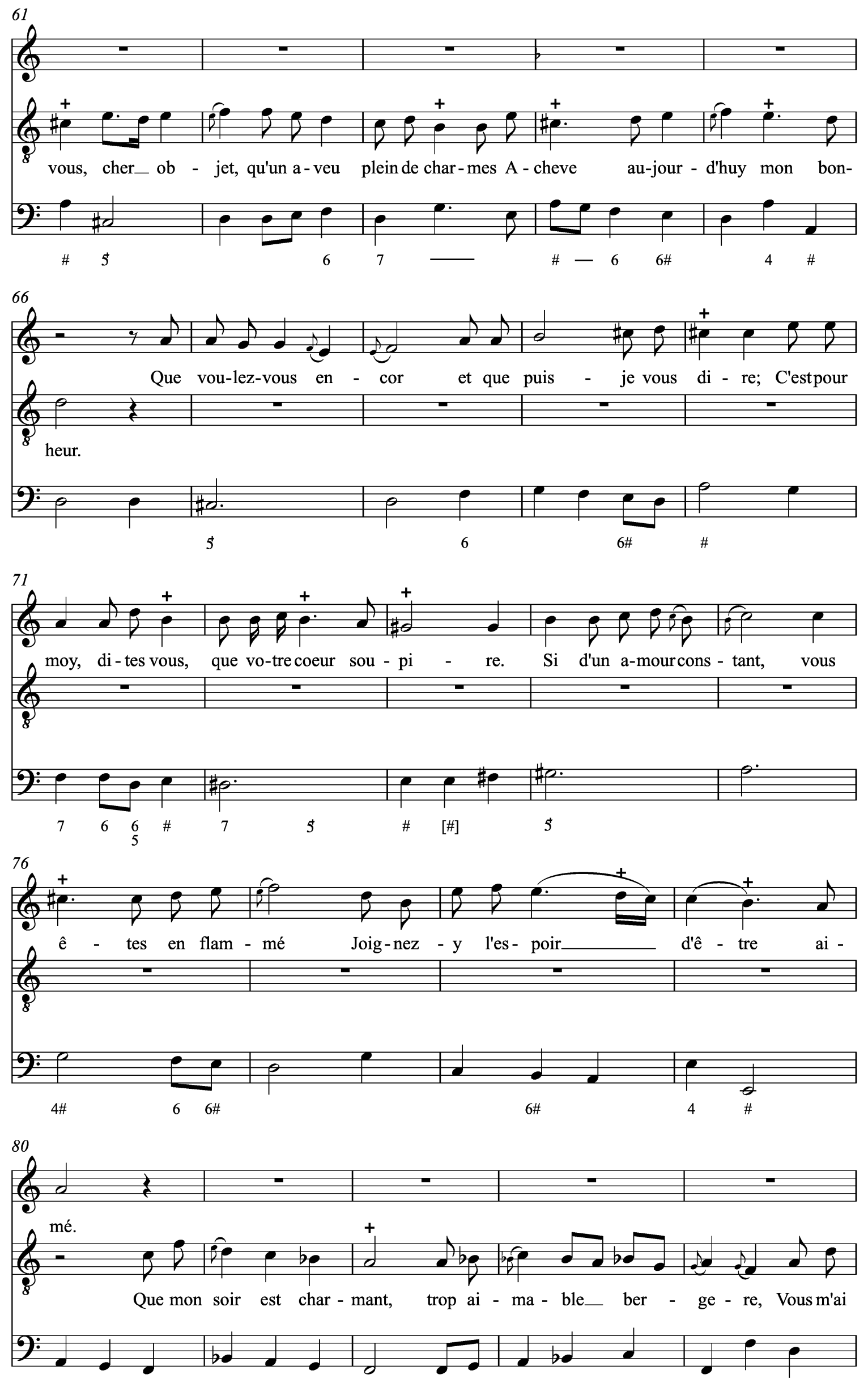

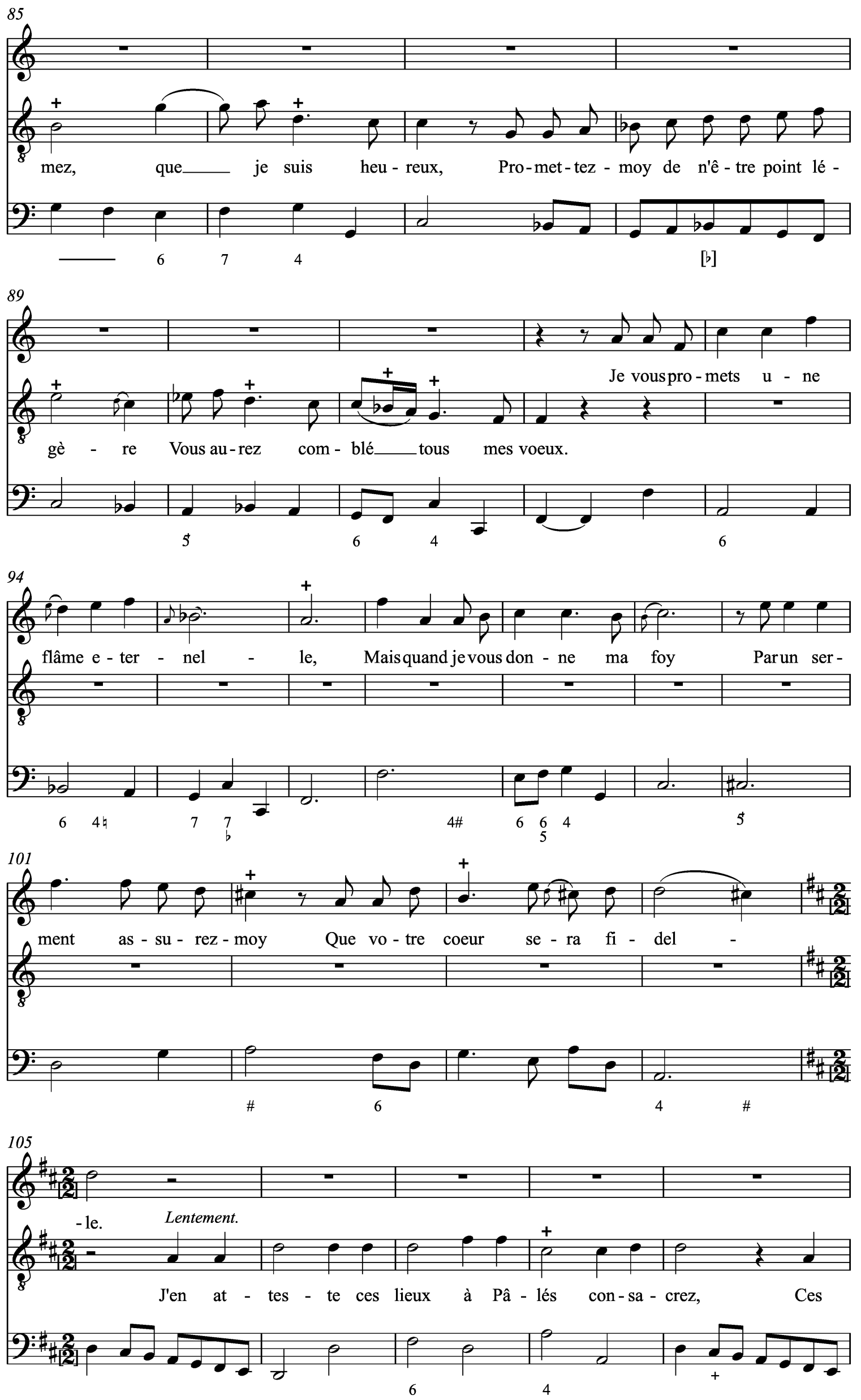
31
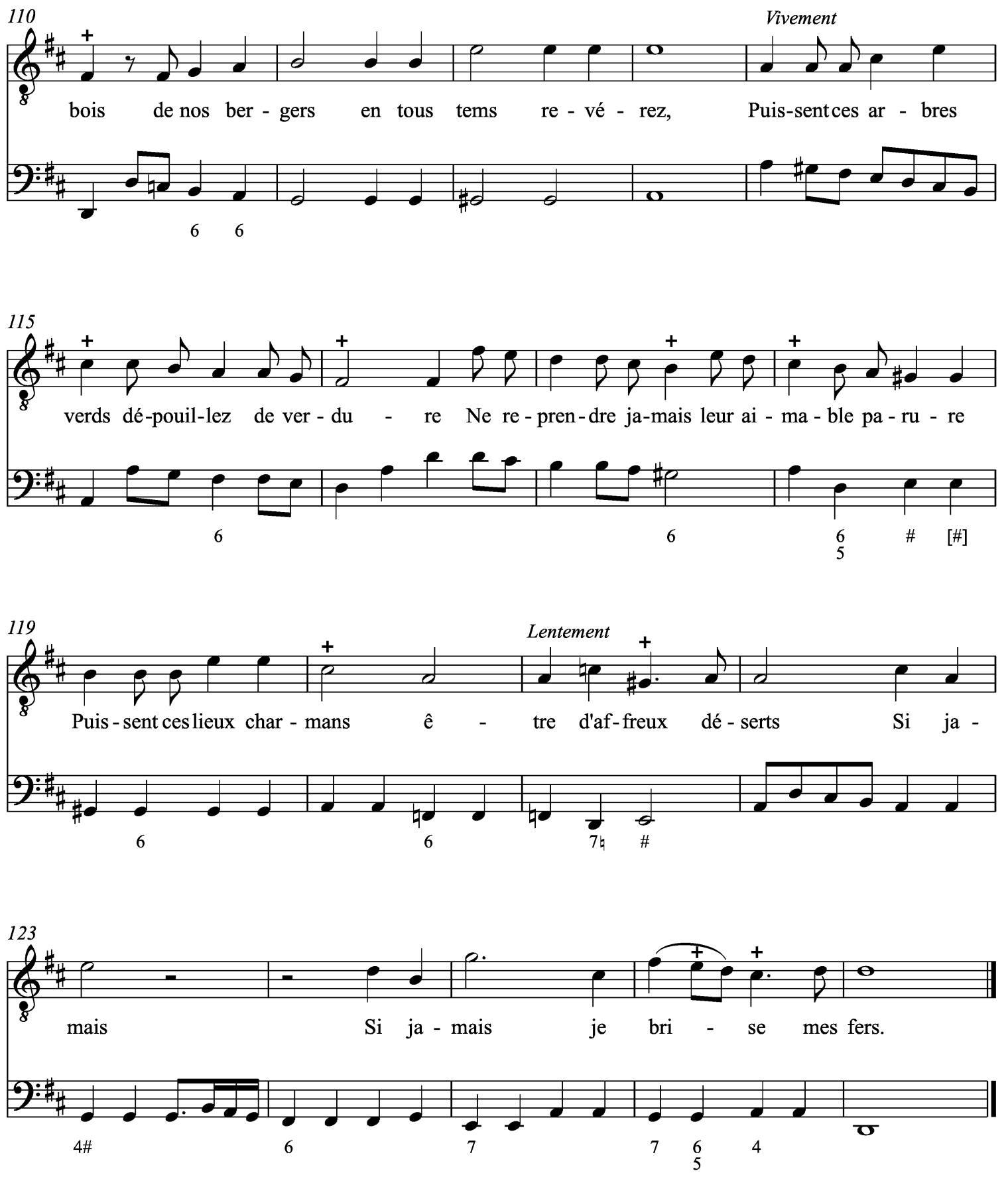

Ensemble

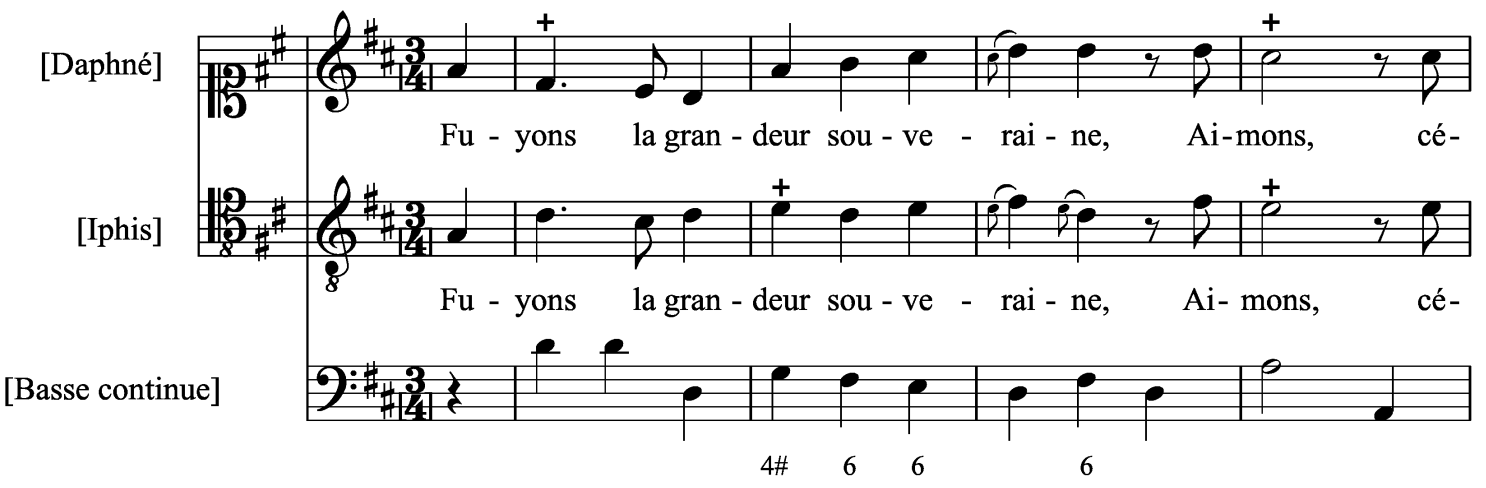



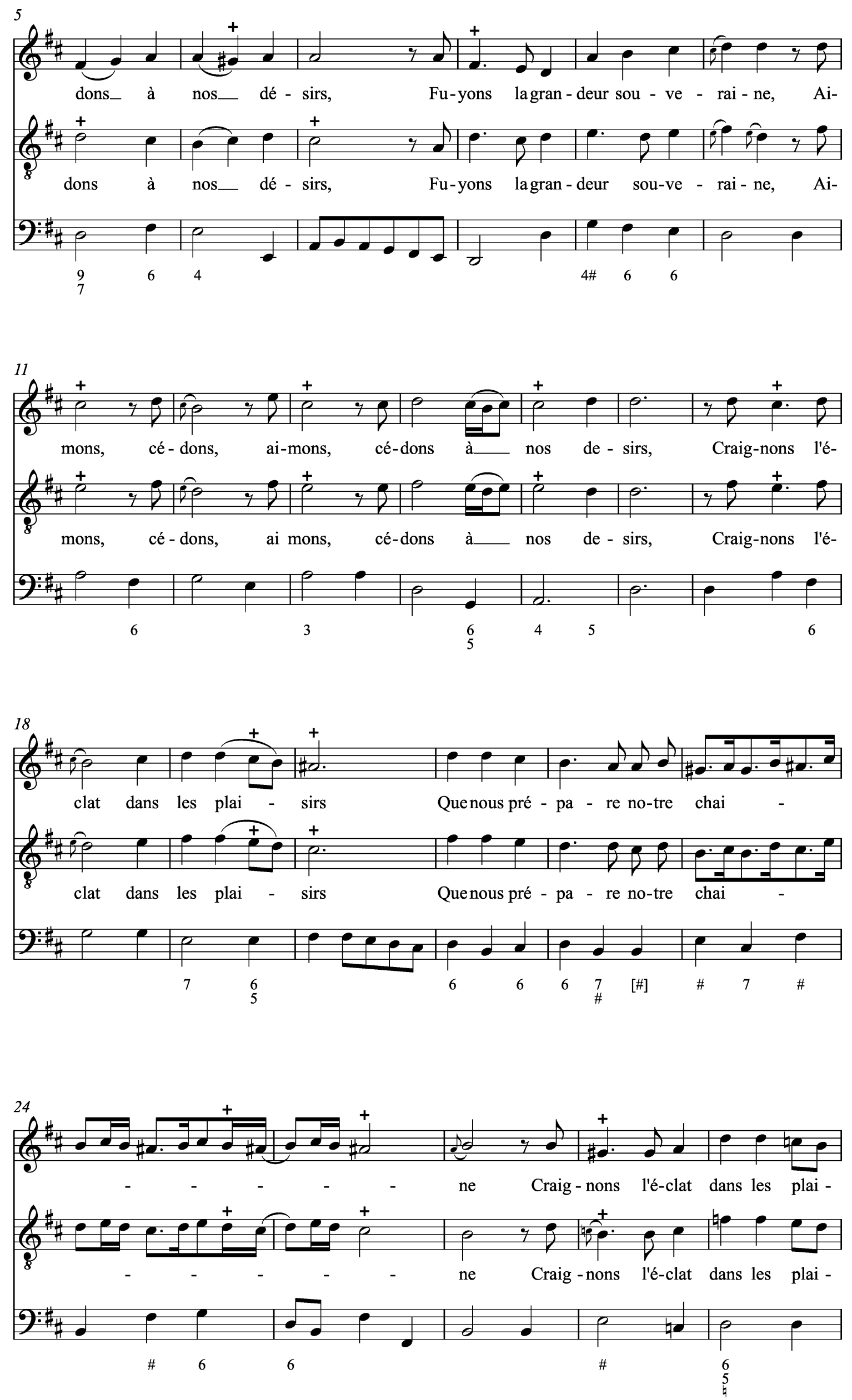

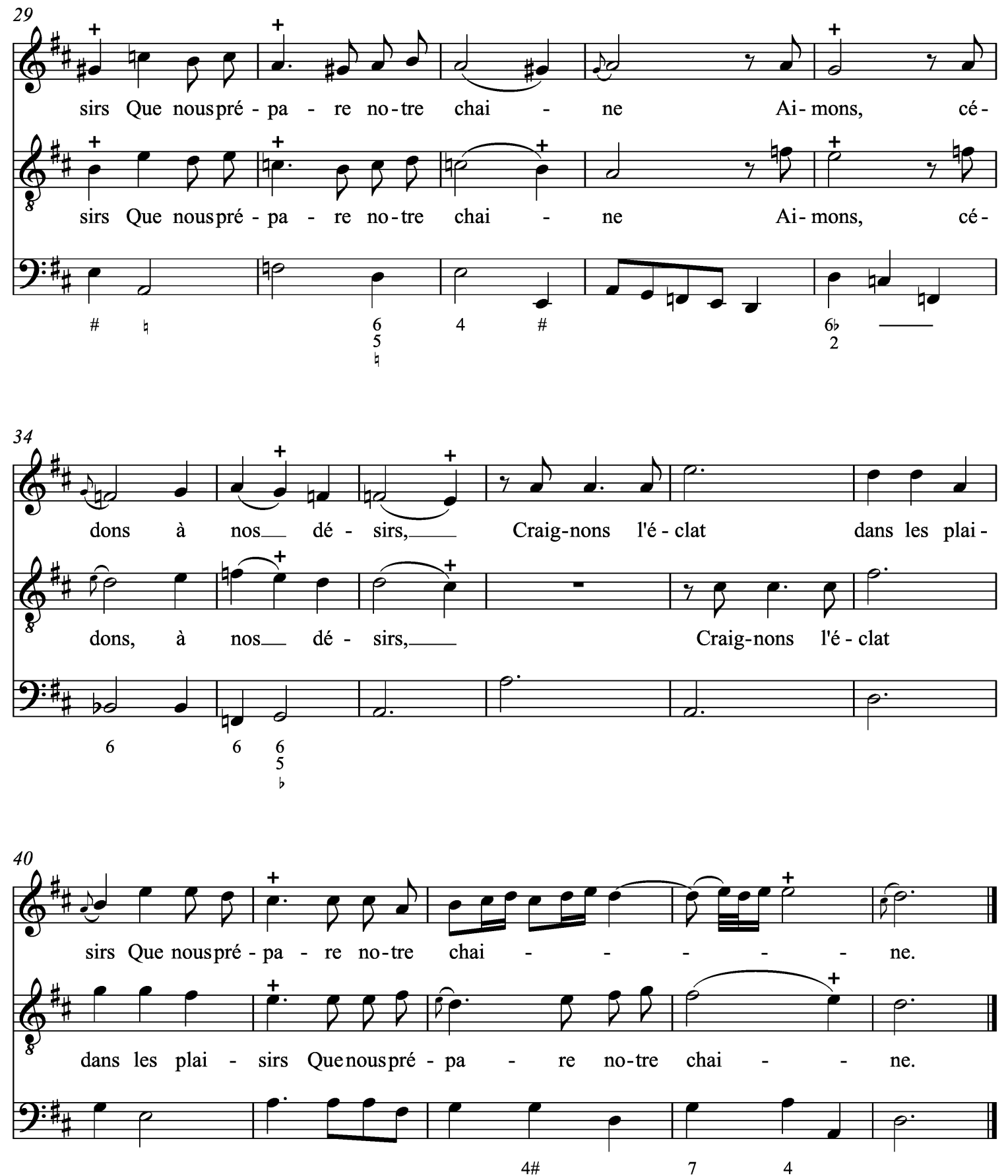


\section{Musette pour un berger}

Air sérieux

[Voix]

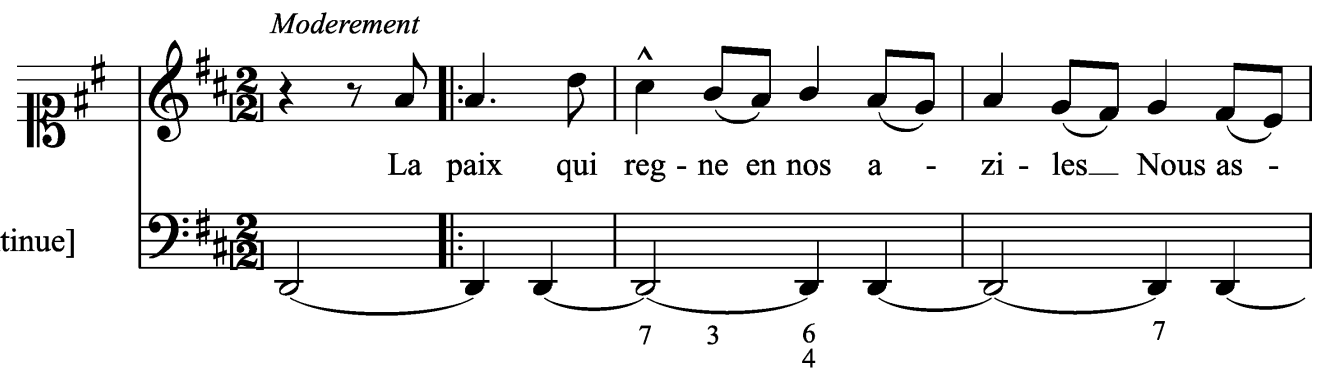

4
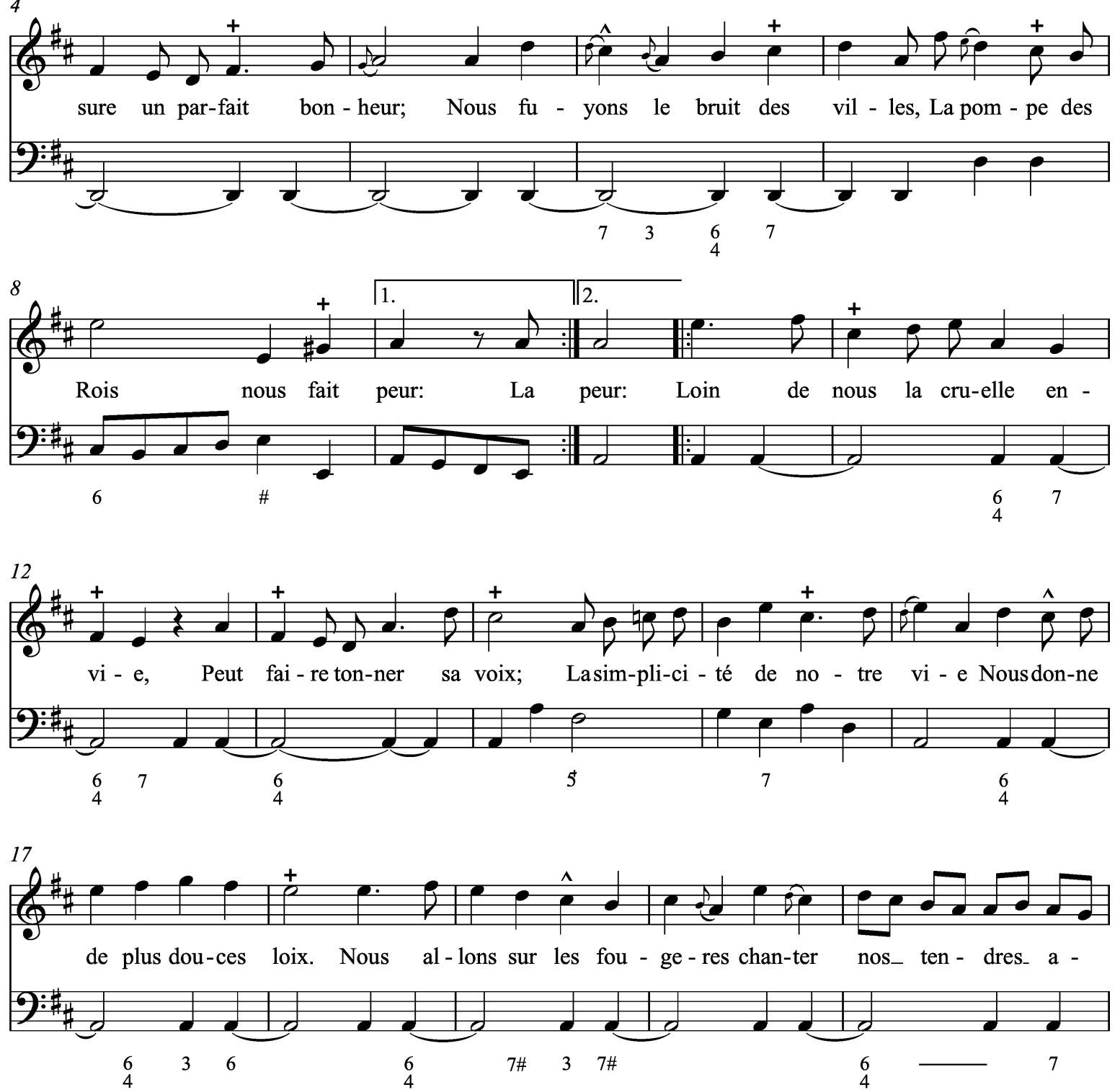

22

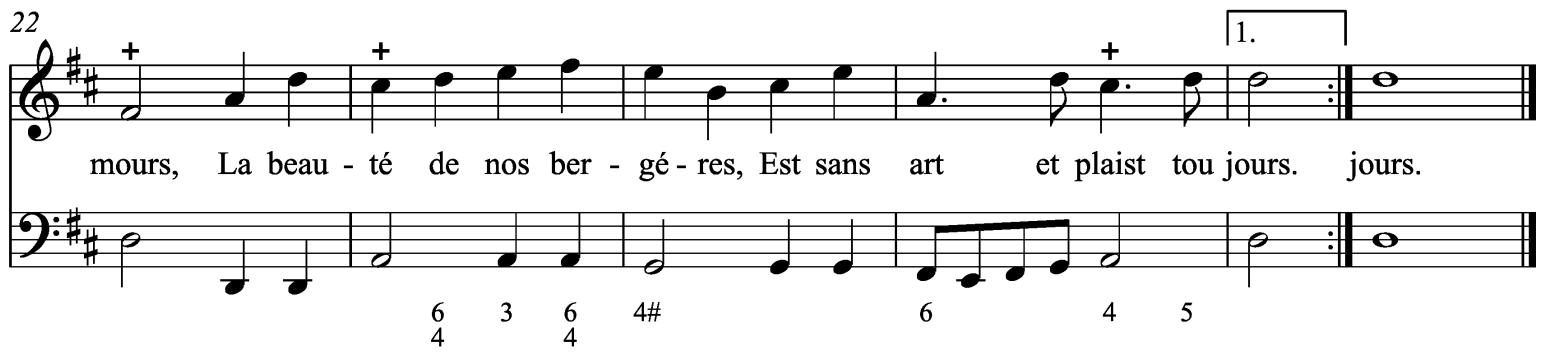


Second couplet. Parodie du premier
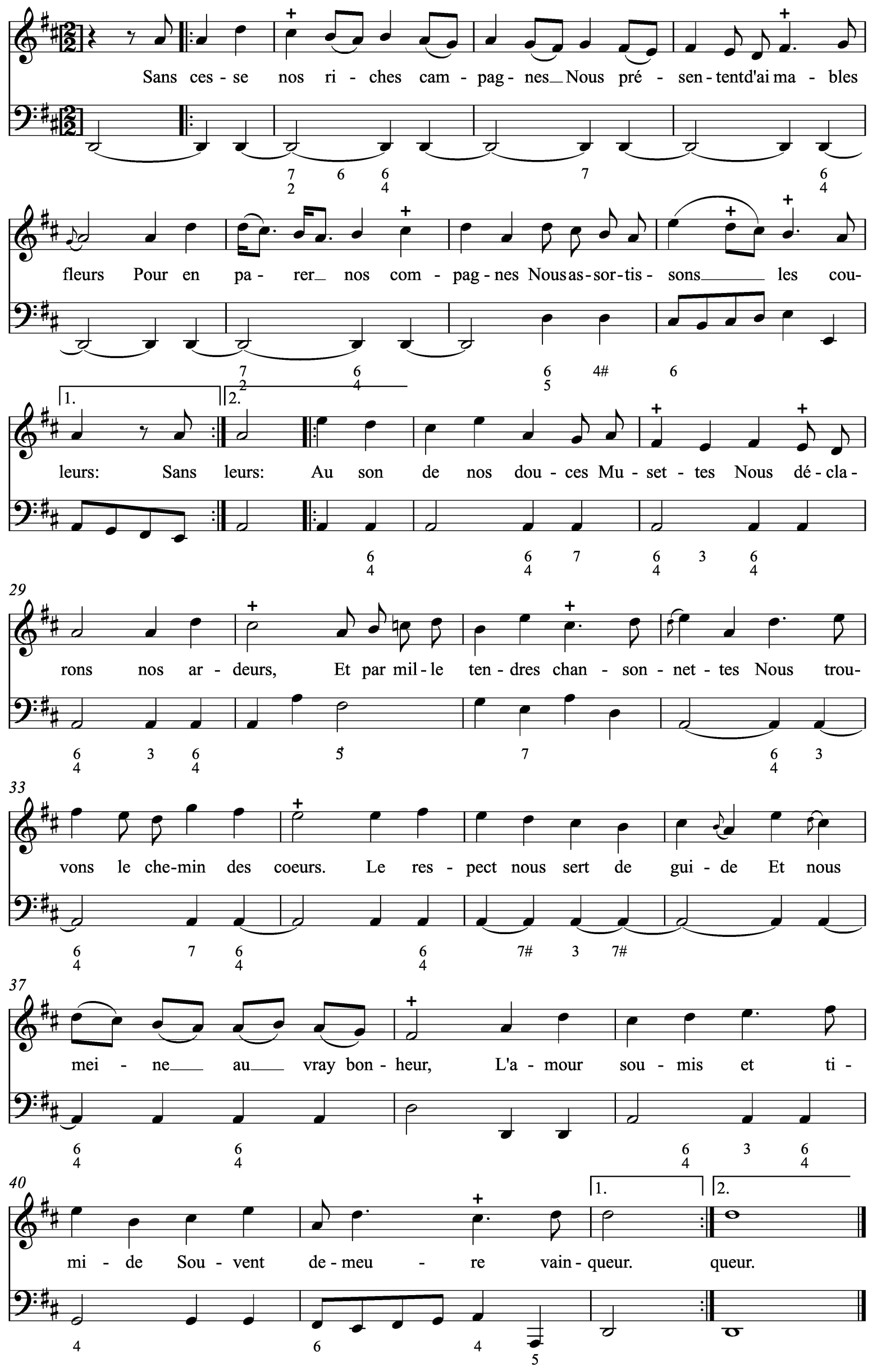


\section{Musette pour une bergere.}

Air sérieux
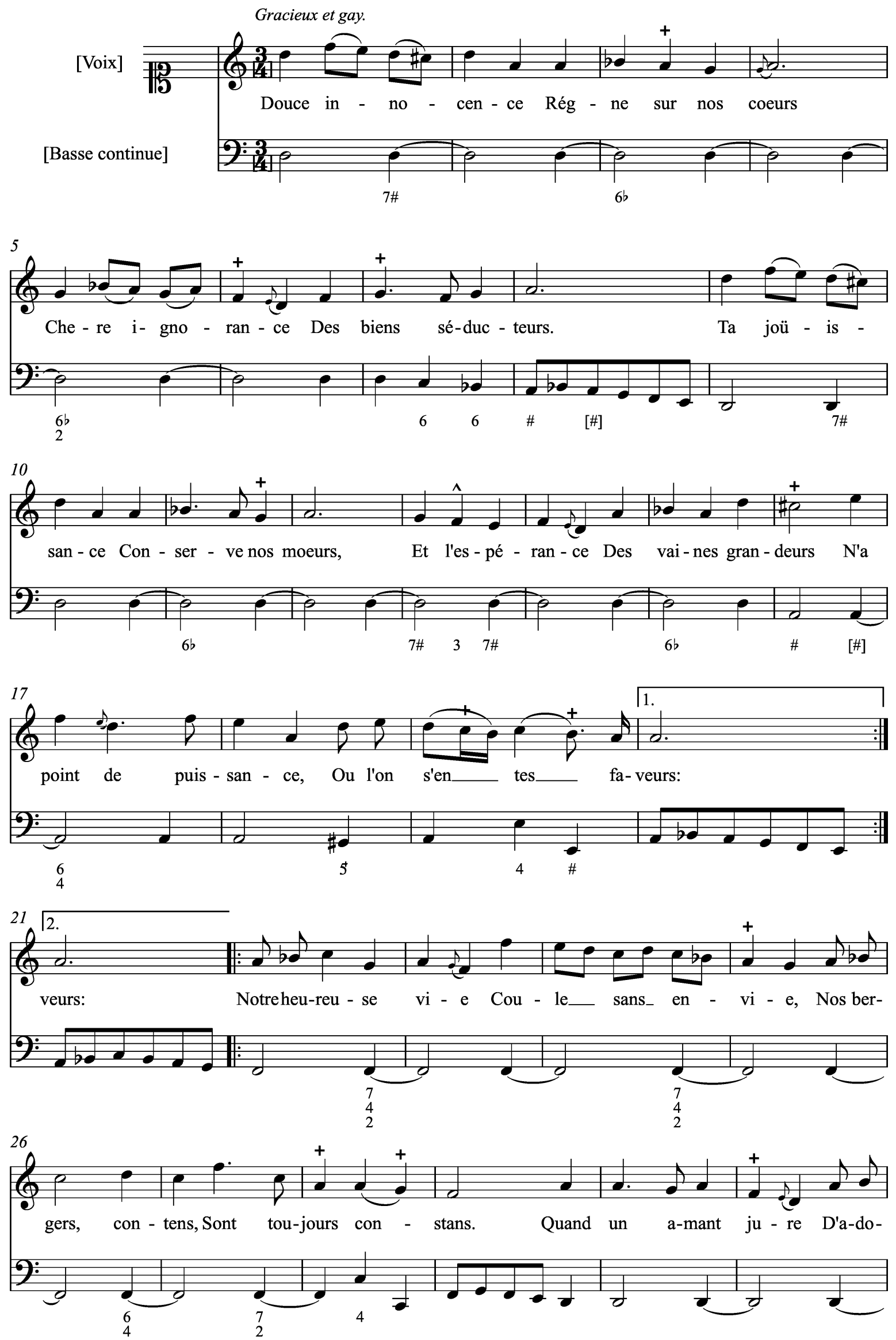

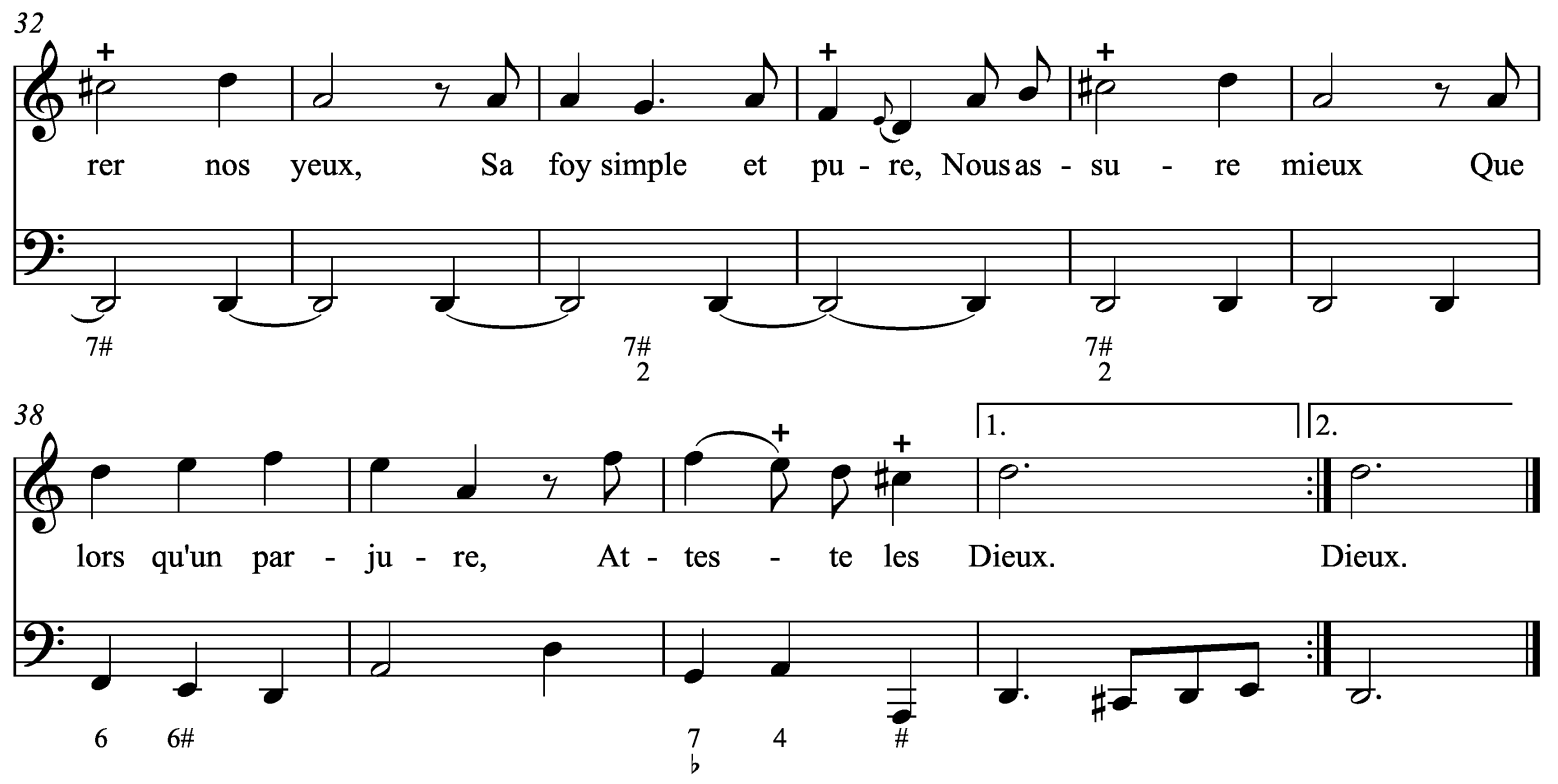


\section{Tendres amans qu'amour engage}

Air sérieux

[Voix]

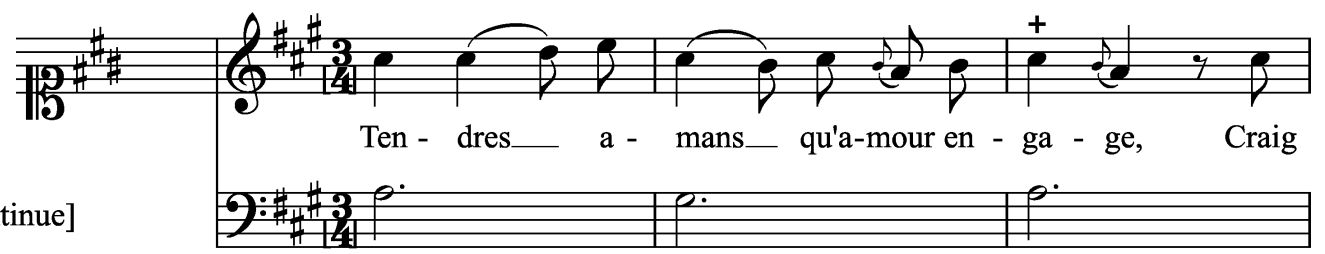

[Basse continue]
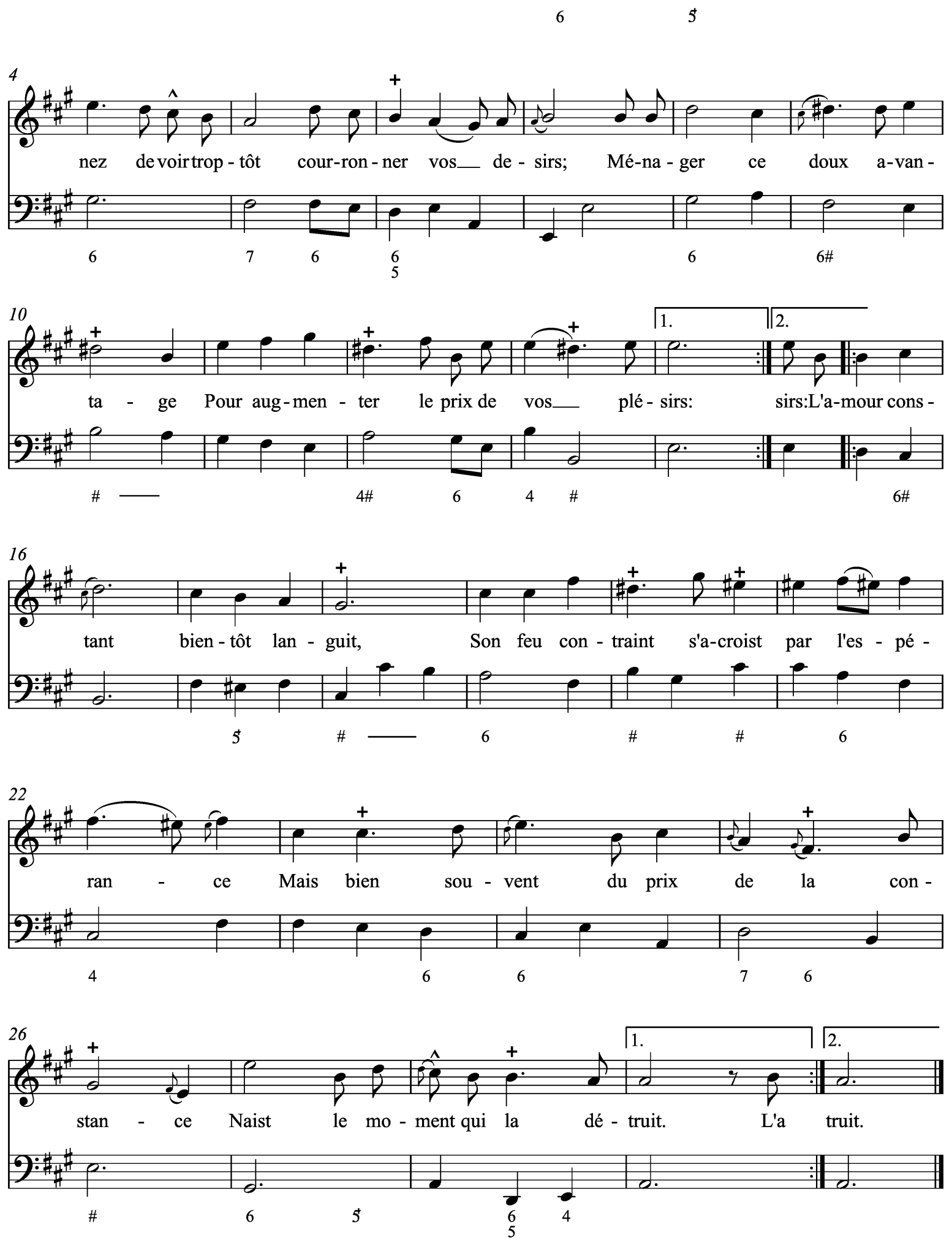


\section{Amans qui languissez}

Air à boire, Récit de Basse

[Voix]

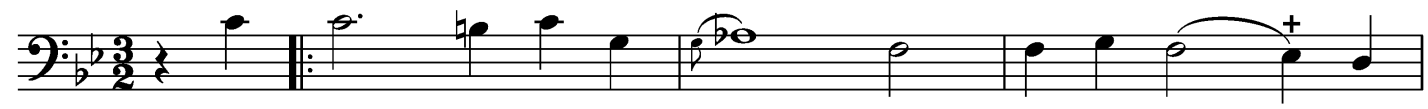

$A$ - qui lan-guis - sez sous de pe - san - tes
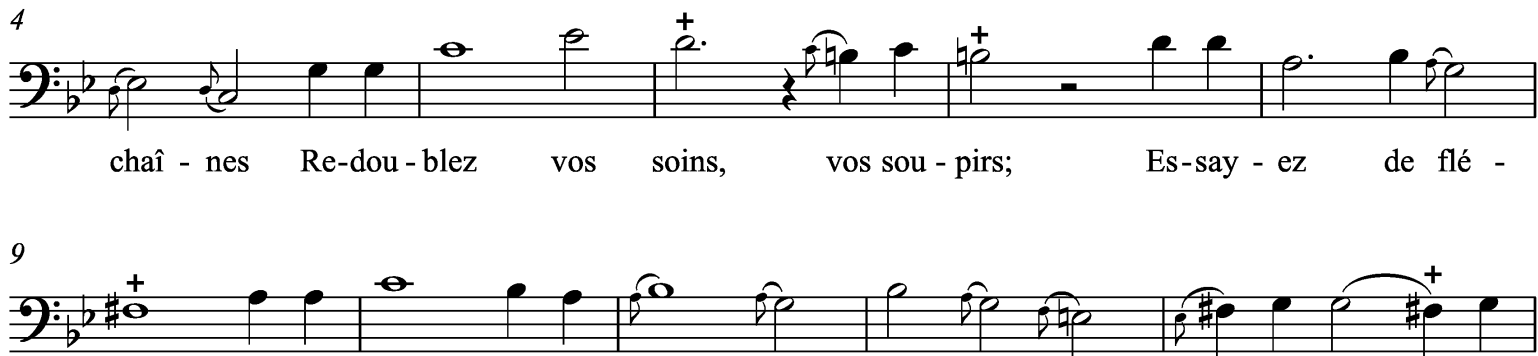
chir des ri-gueurs in - hu - mai - nes, Pour ar - ri - ver aux vrais plai-
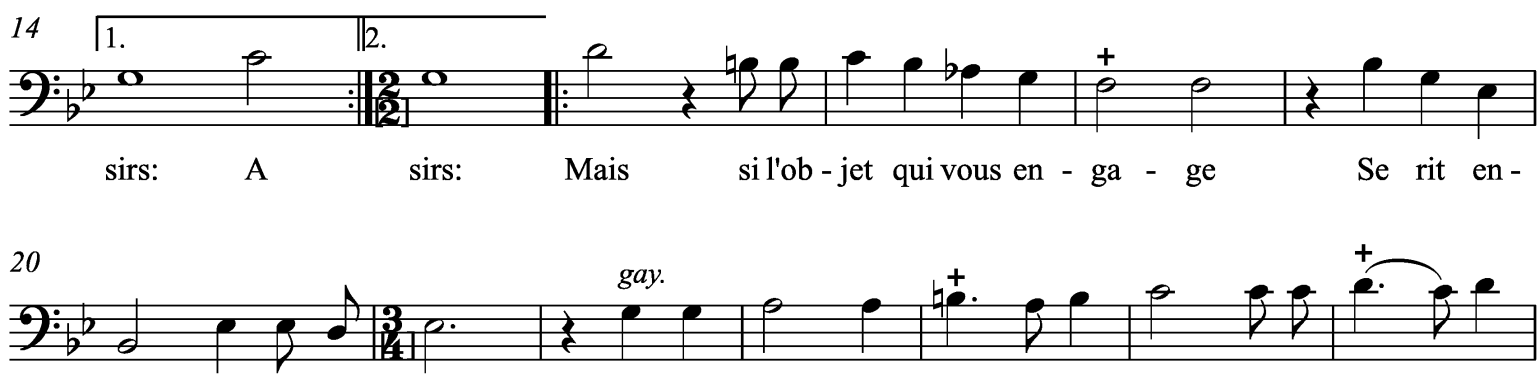

cor de vosdou - leurs, C'estBac-chus qui sei - cheles pleurs Des a- mans_cons-
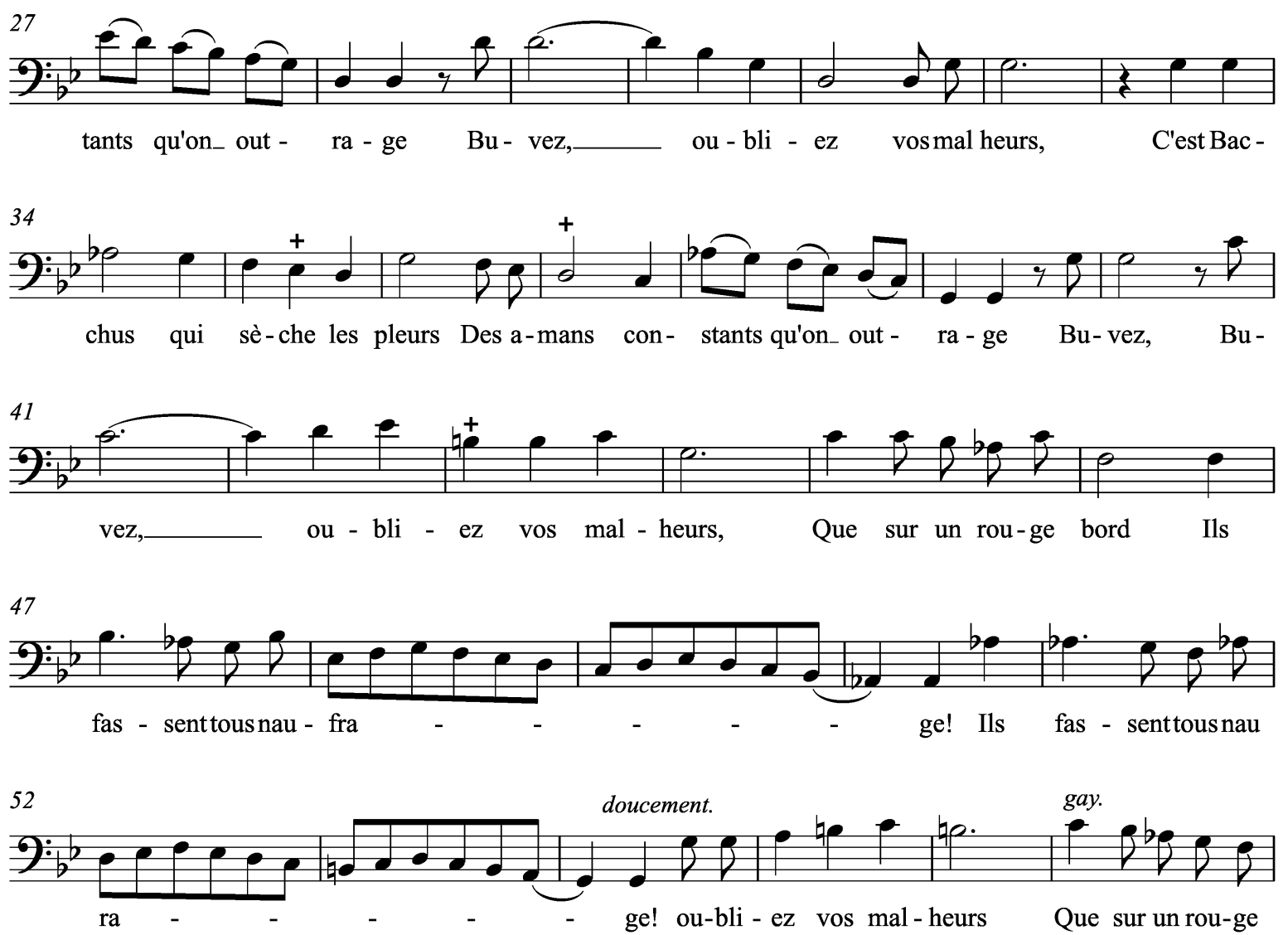
58

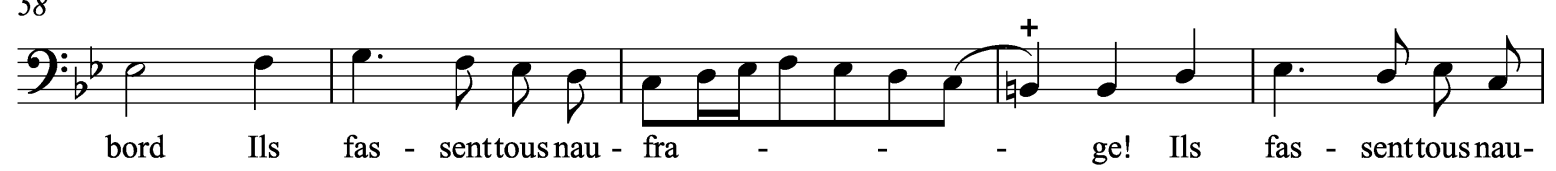

63
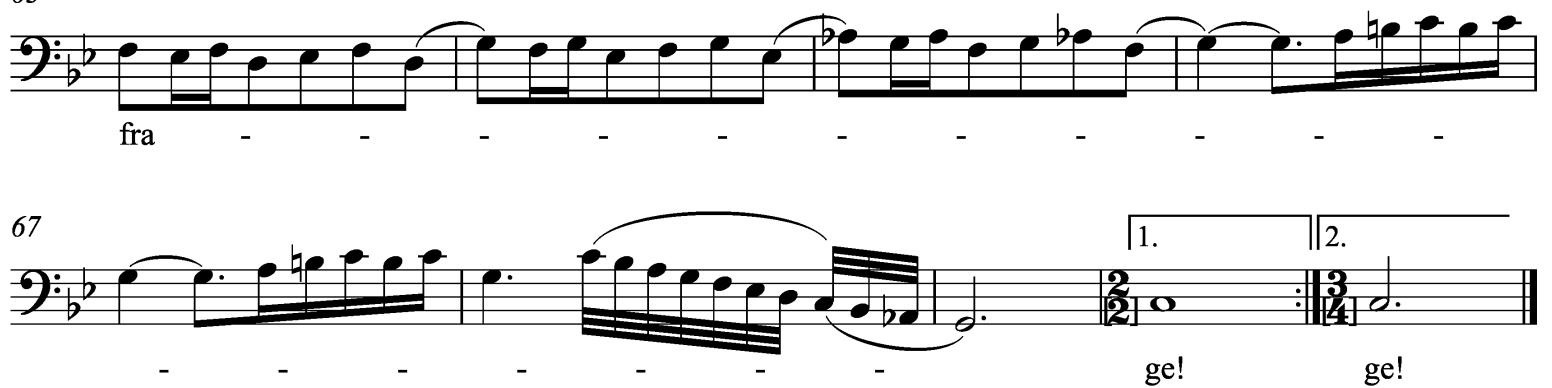


\section{Buvons tous à la ronde}

Fanfare: Air à boire

[Voix

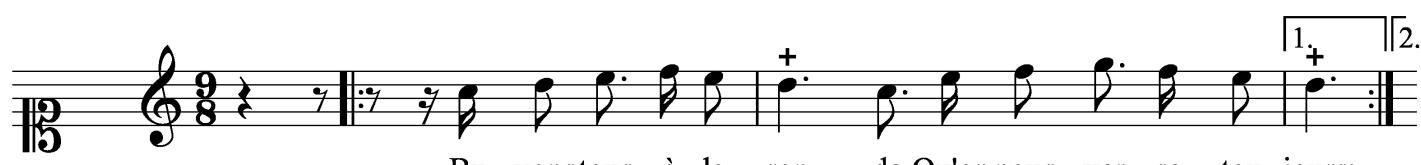

$\mathrm{Bu}$ - vonstous à la ron - de Qu'onnous ver - se tou-jours:

Pe - tit dieu de $\mathrm{Cy}$ - the - re Rends ho-mmage à Bac-chus:

I - ris à ce-tte ta - ble Dé - ter - mi - ne mon choix:
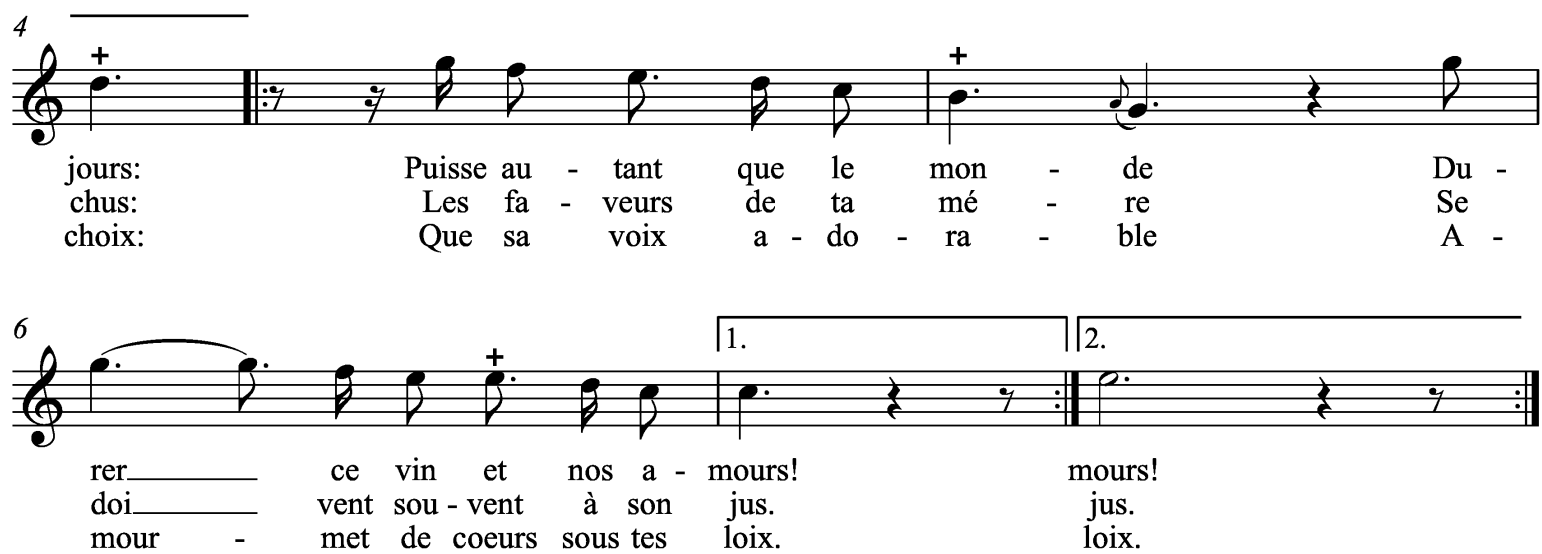


\section{Boccages frais}

Brunette a deux Dessus
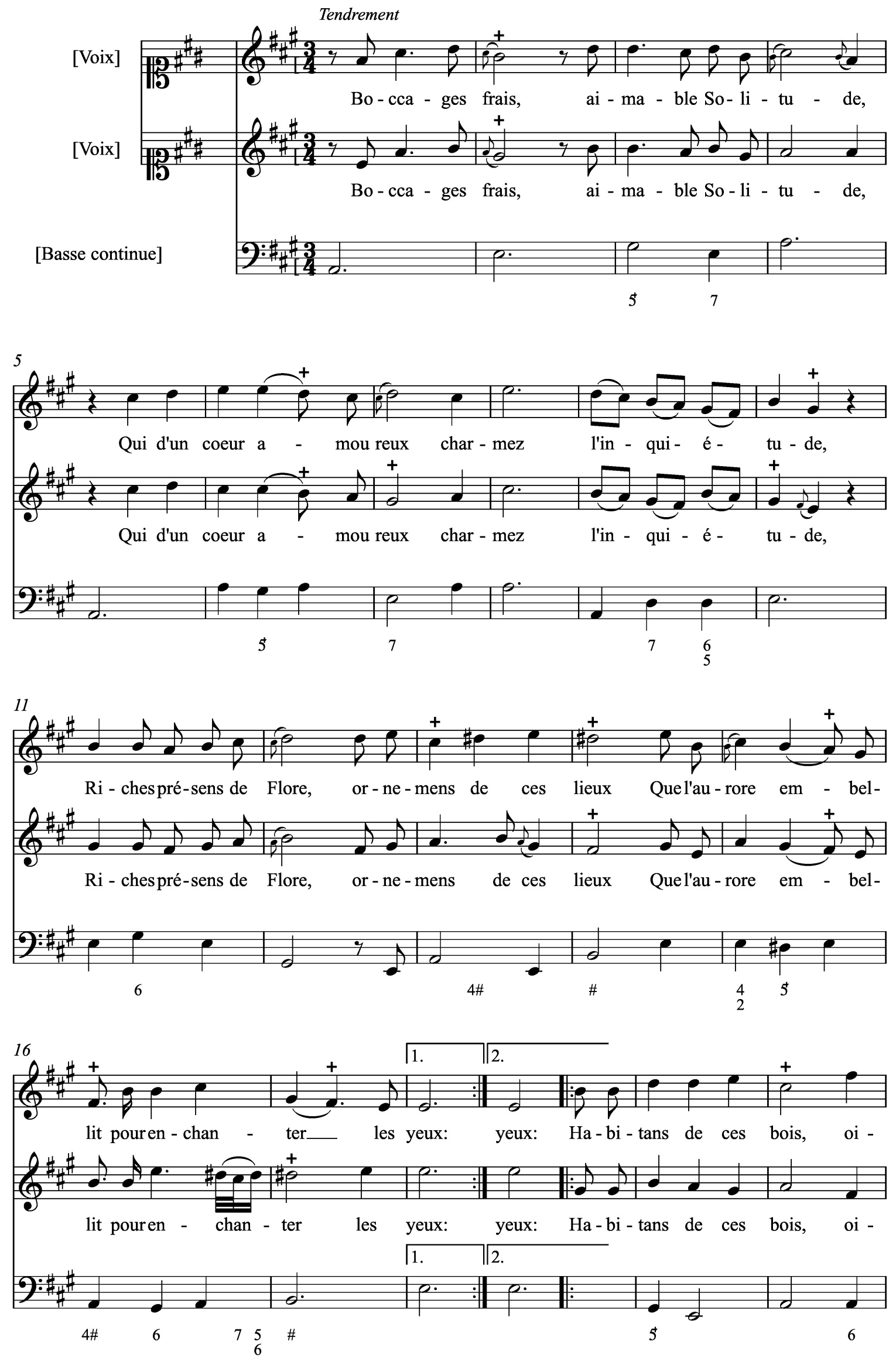

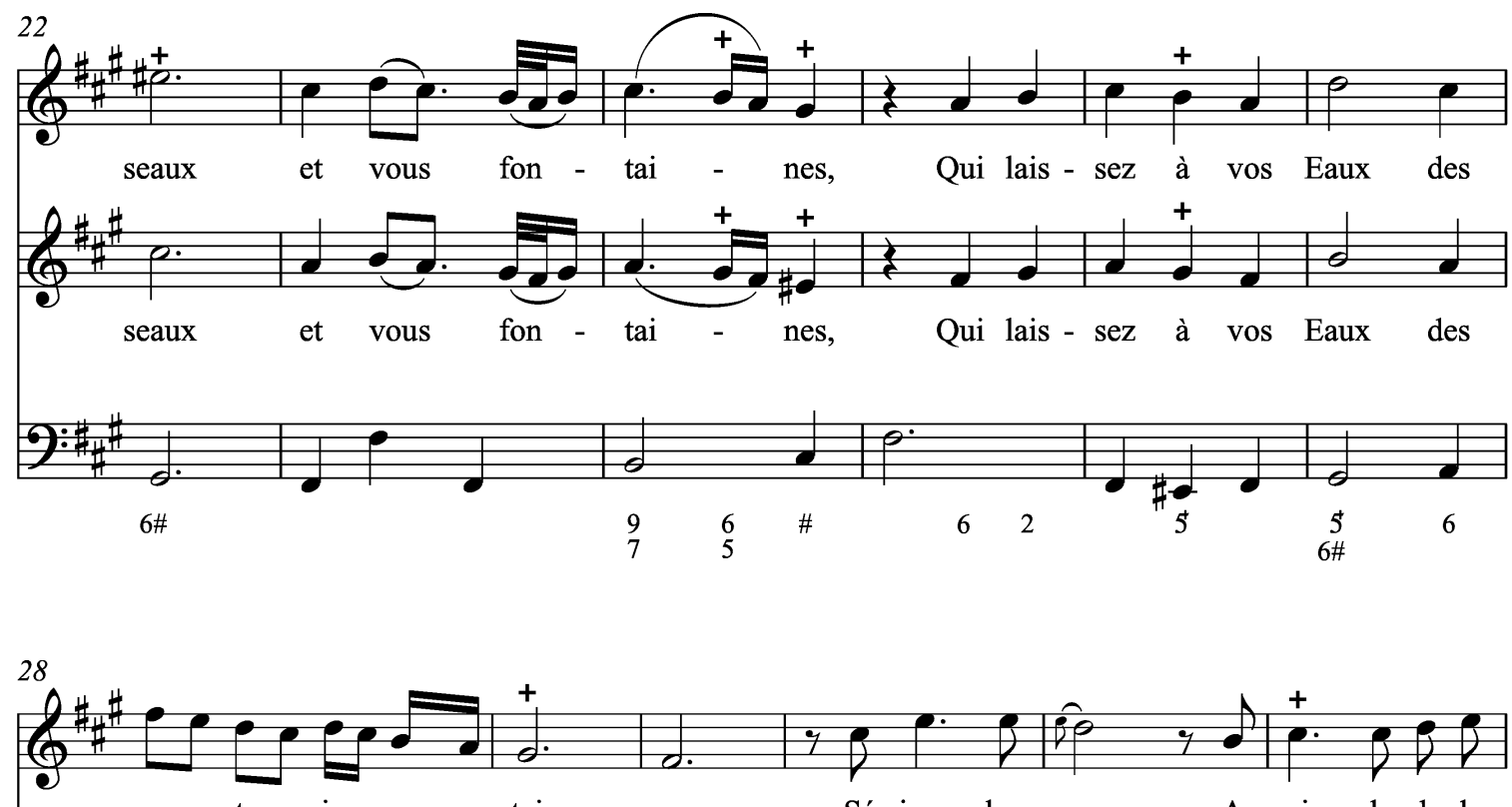
rou - tes_ in - cer - tai - nes, Sé-jour heu-reux, A - zi - le de la

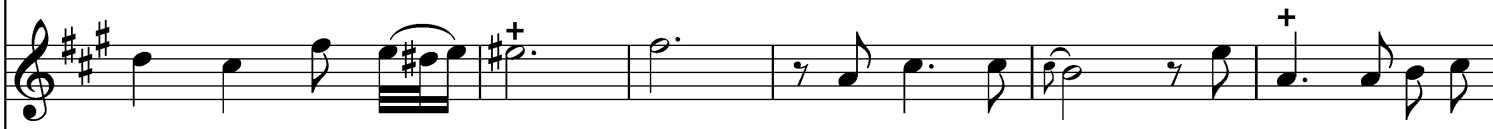
rou - tes in - cer - tai - nes, Sé-jour heu-reux, A - zi - le de la

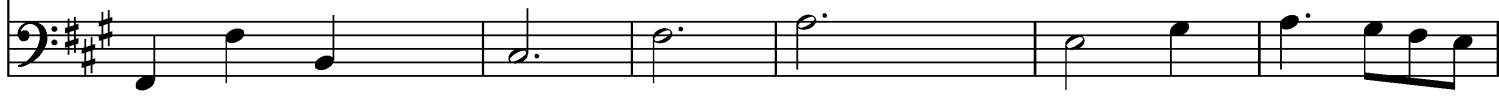

54

7

6

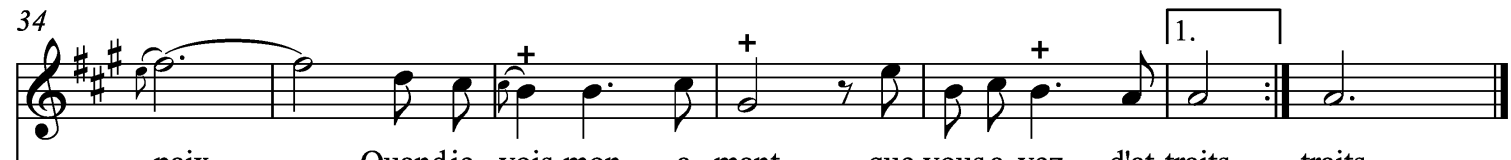
paix,__ Quandje vois mon a-mant que vousa-vez d'at traits. traits.

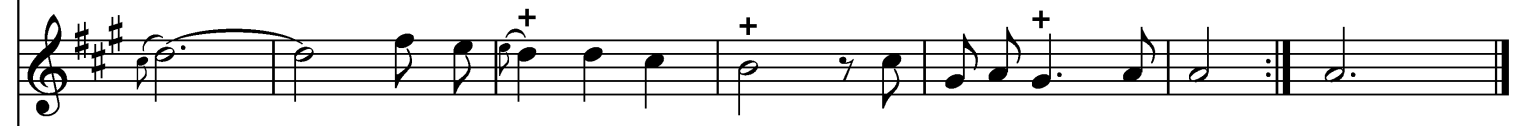
paix,__ Quandje vois mon a - mant que vous a-vez d'at traits. traits.

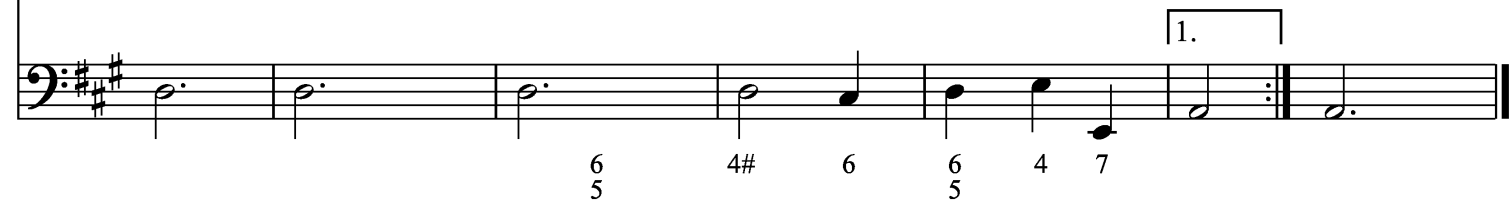

\section{Deuxième couplet}

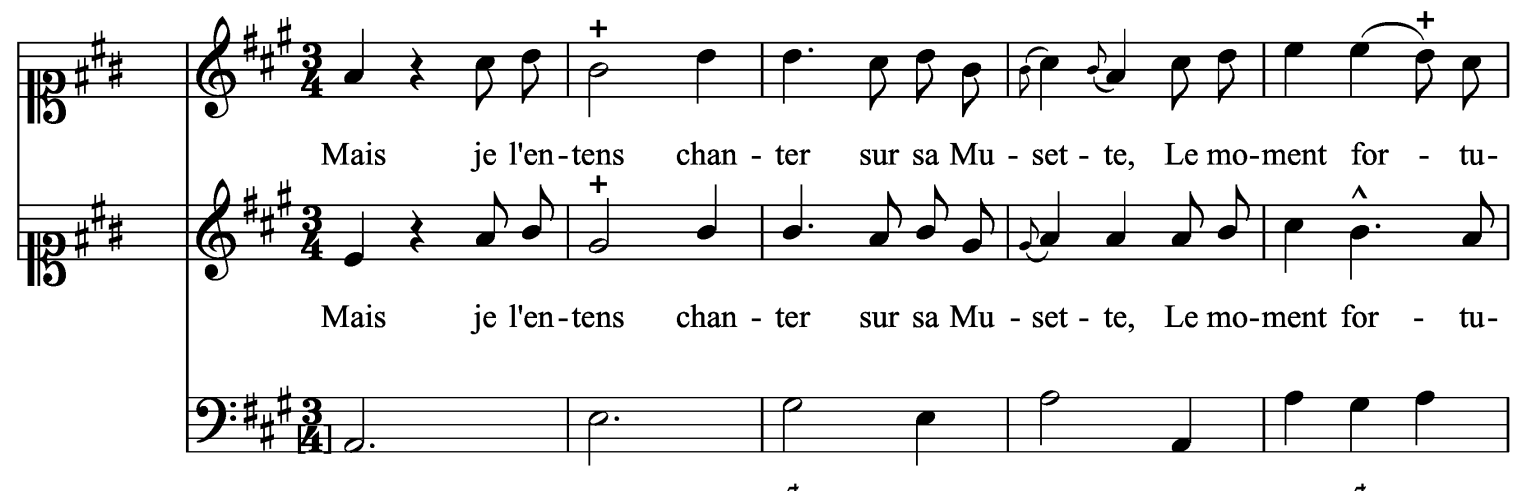



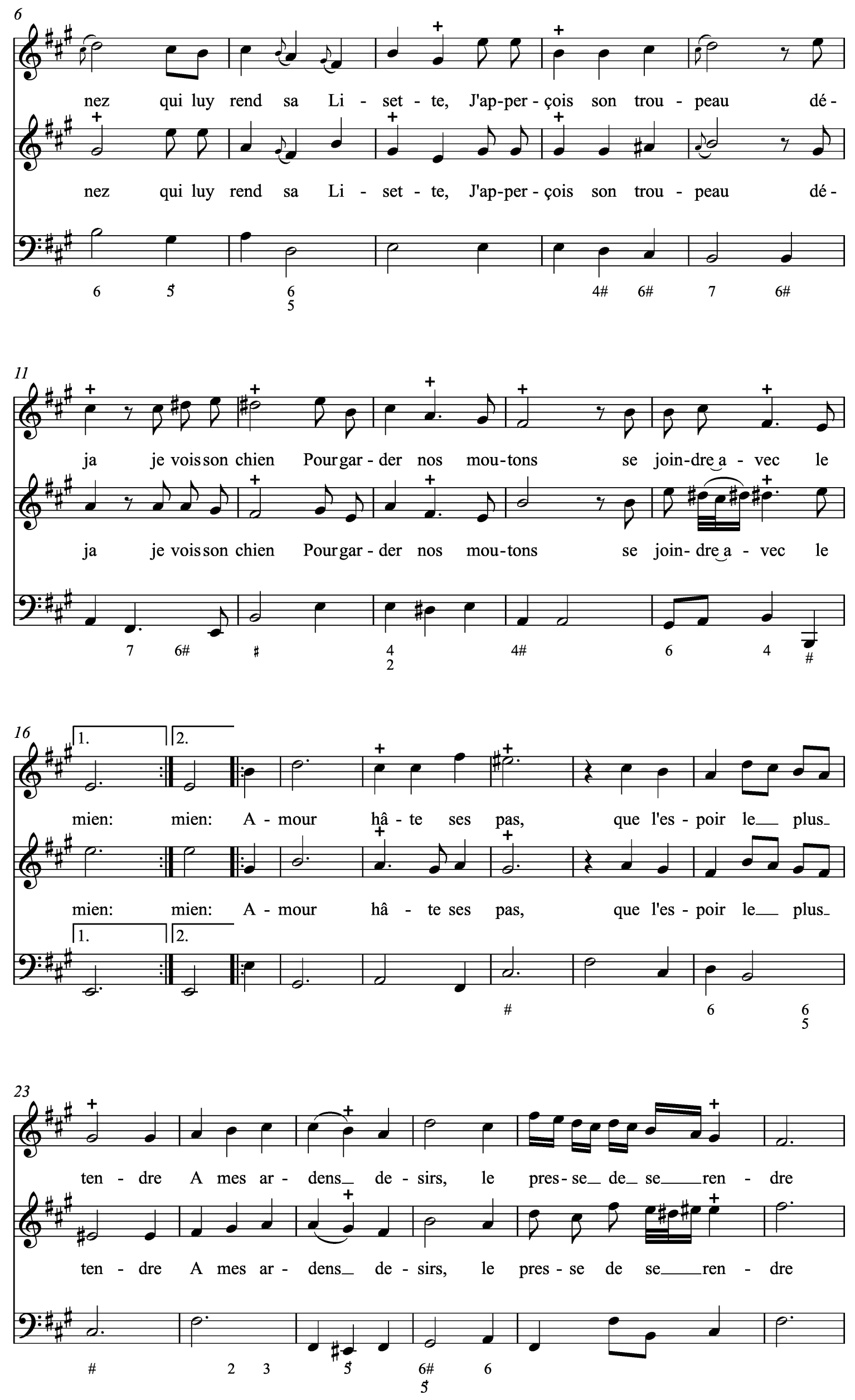

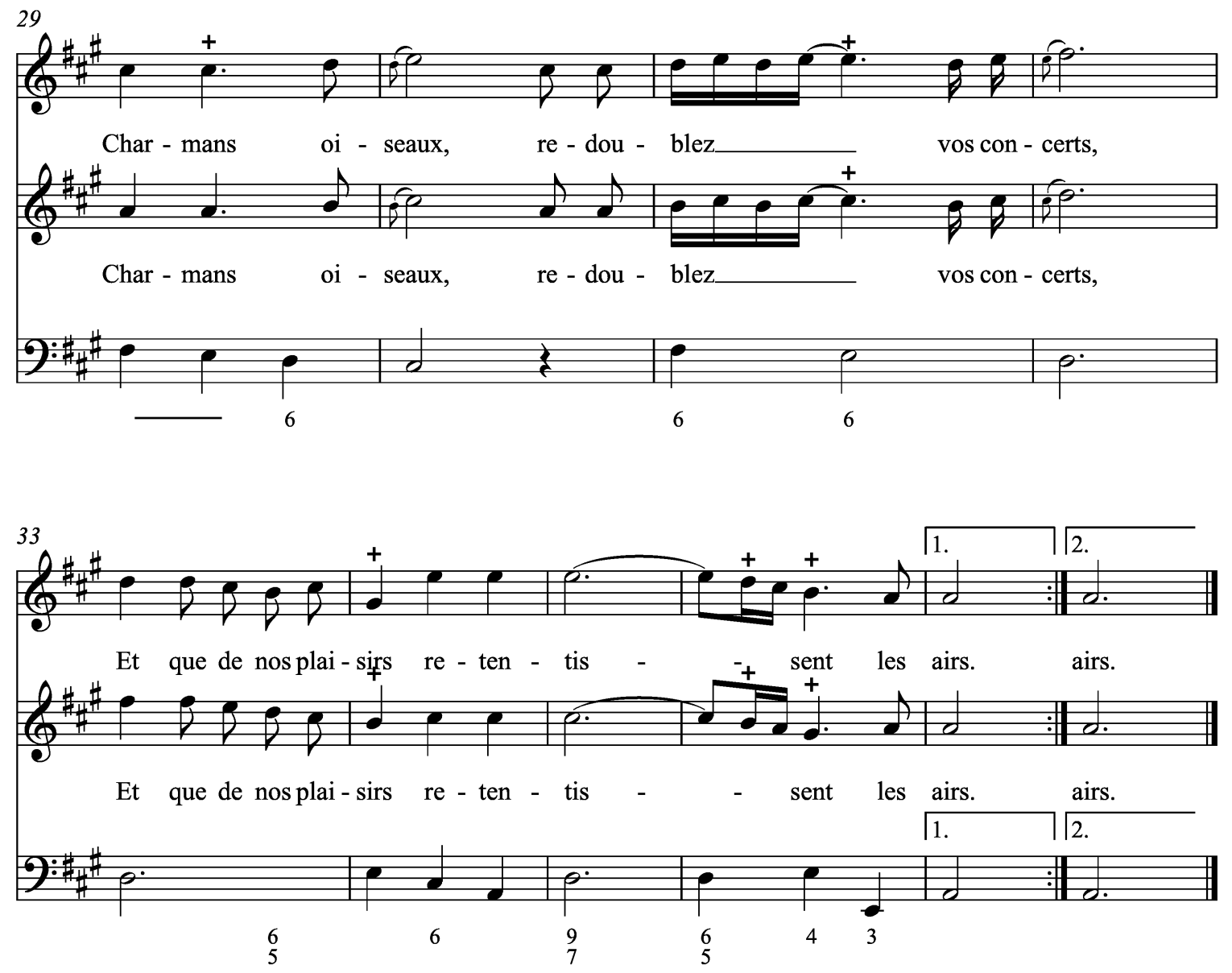


\section{Célimeine à changé}

Air à boire a deux Voix egales

[Voix]

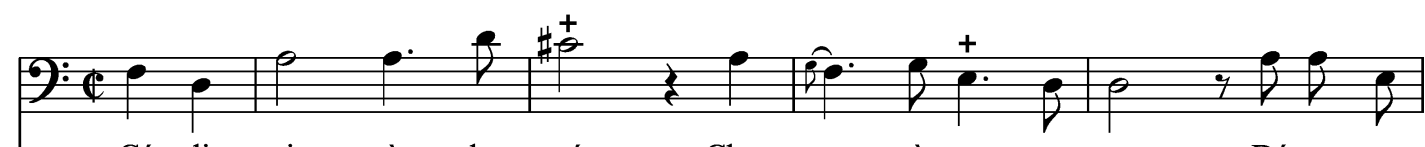

Cé - li - meine à chan-gé, Chan-geons à no - tre tour, Dé ga-geons

[Voix]

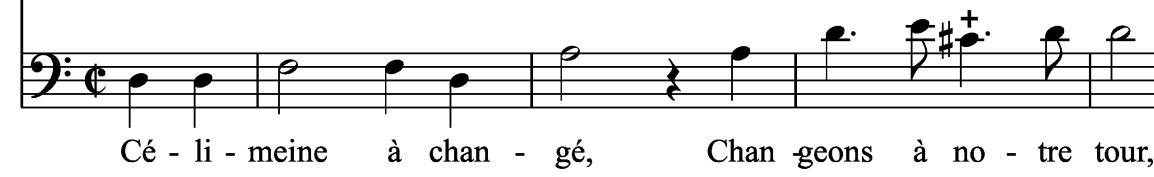

5

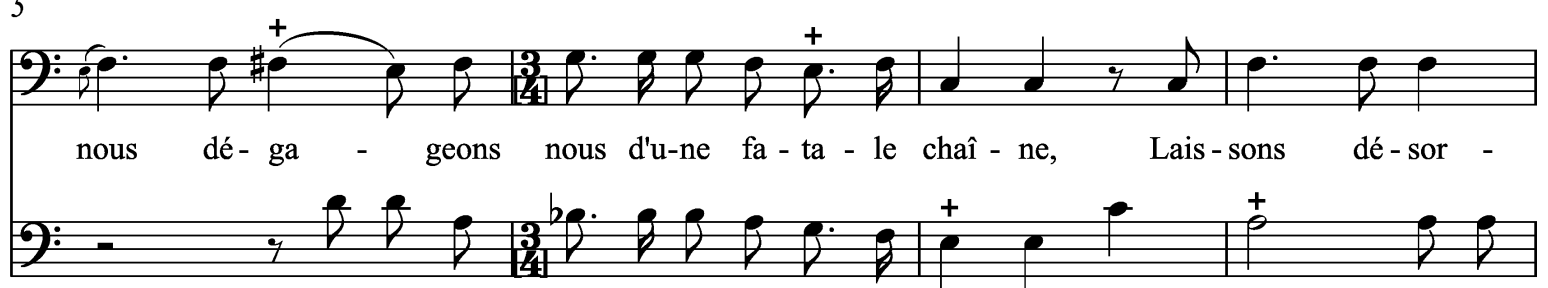

Dé-ga-geons nous d'u-ne fa - ta - le chaî - ne, Lais - sons

dé - sor -

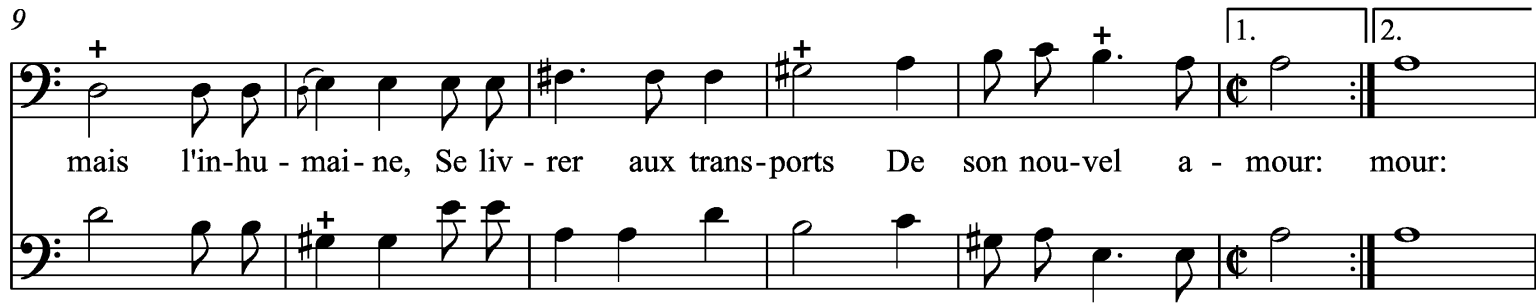

mais l'in-hu - mai-ne, Se liv - rer aux trans-ports De son nou-vel a - mour: mour:
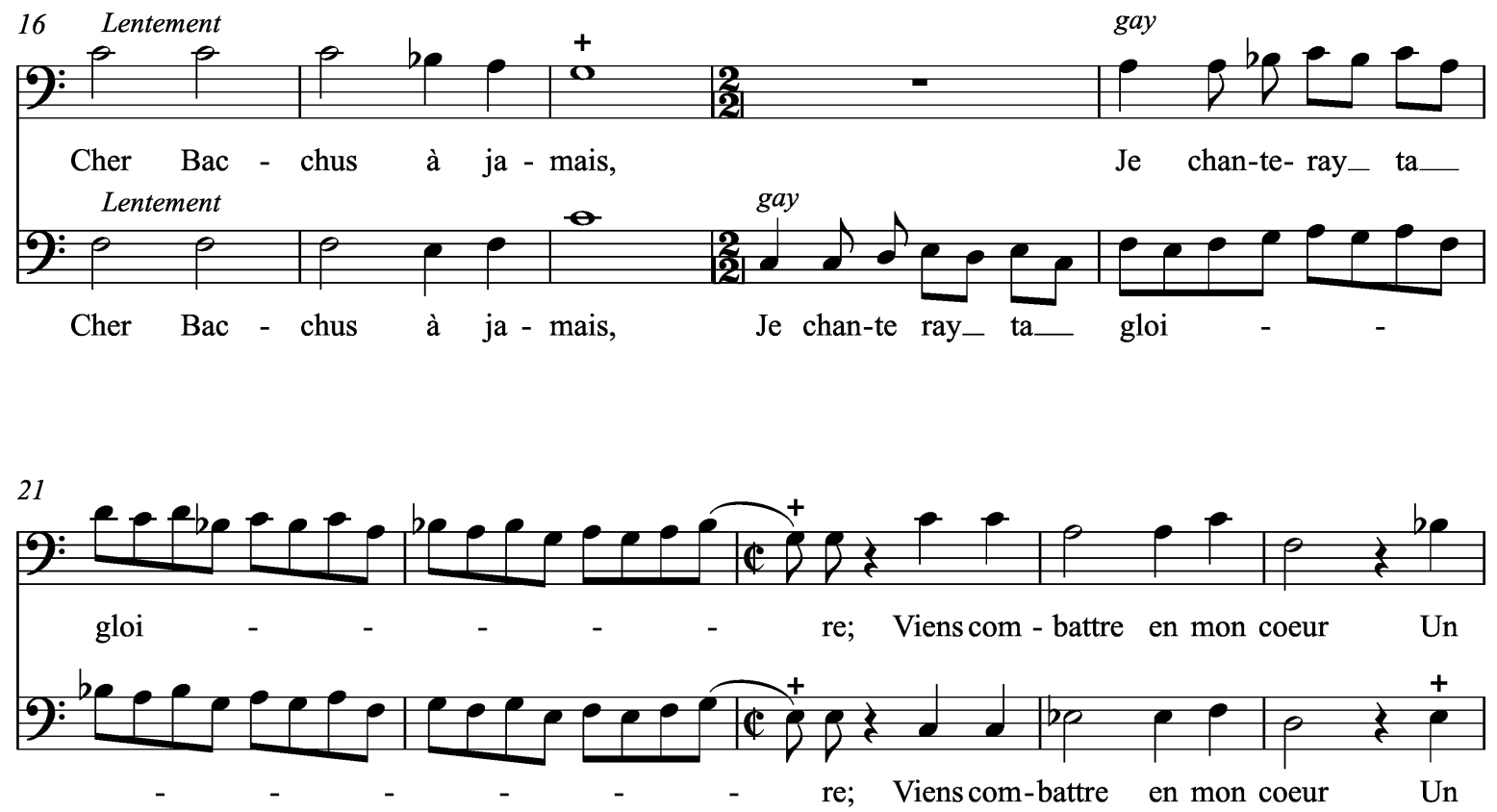

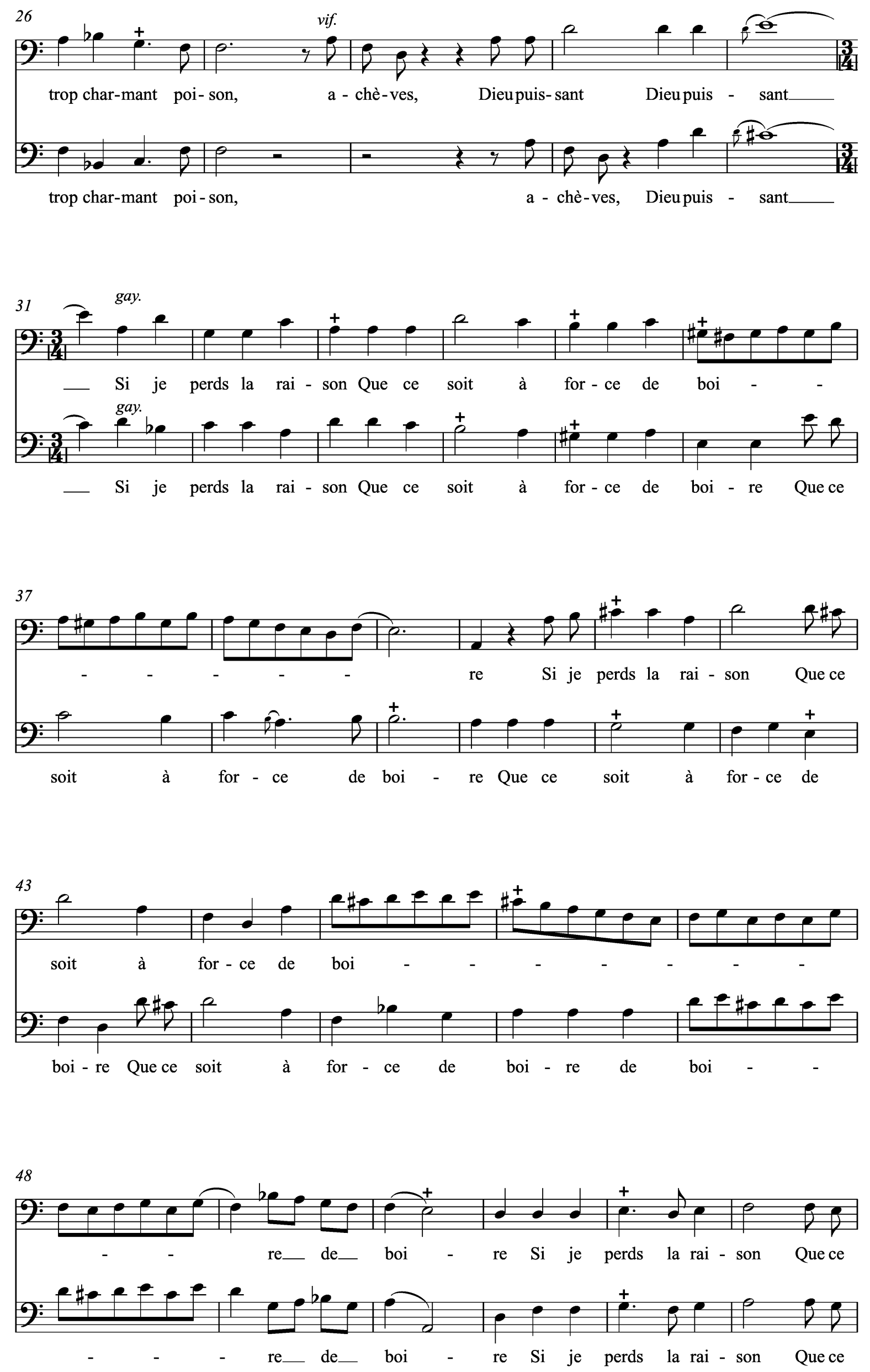

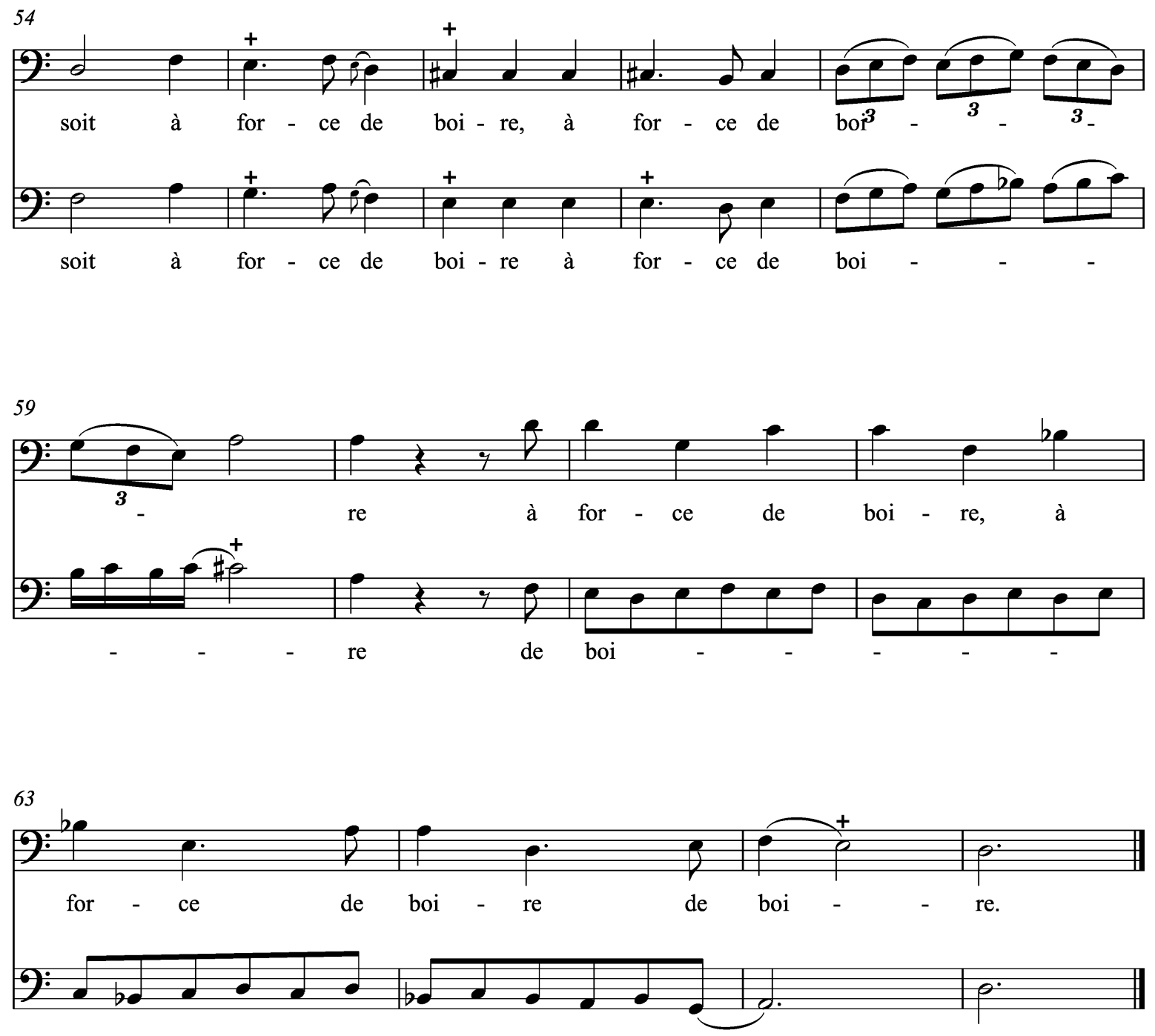

re. 


\section{Pourquoy le berger qui m'engage}

Air sérieux Brunette a deux Dessus

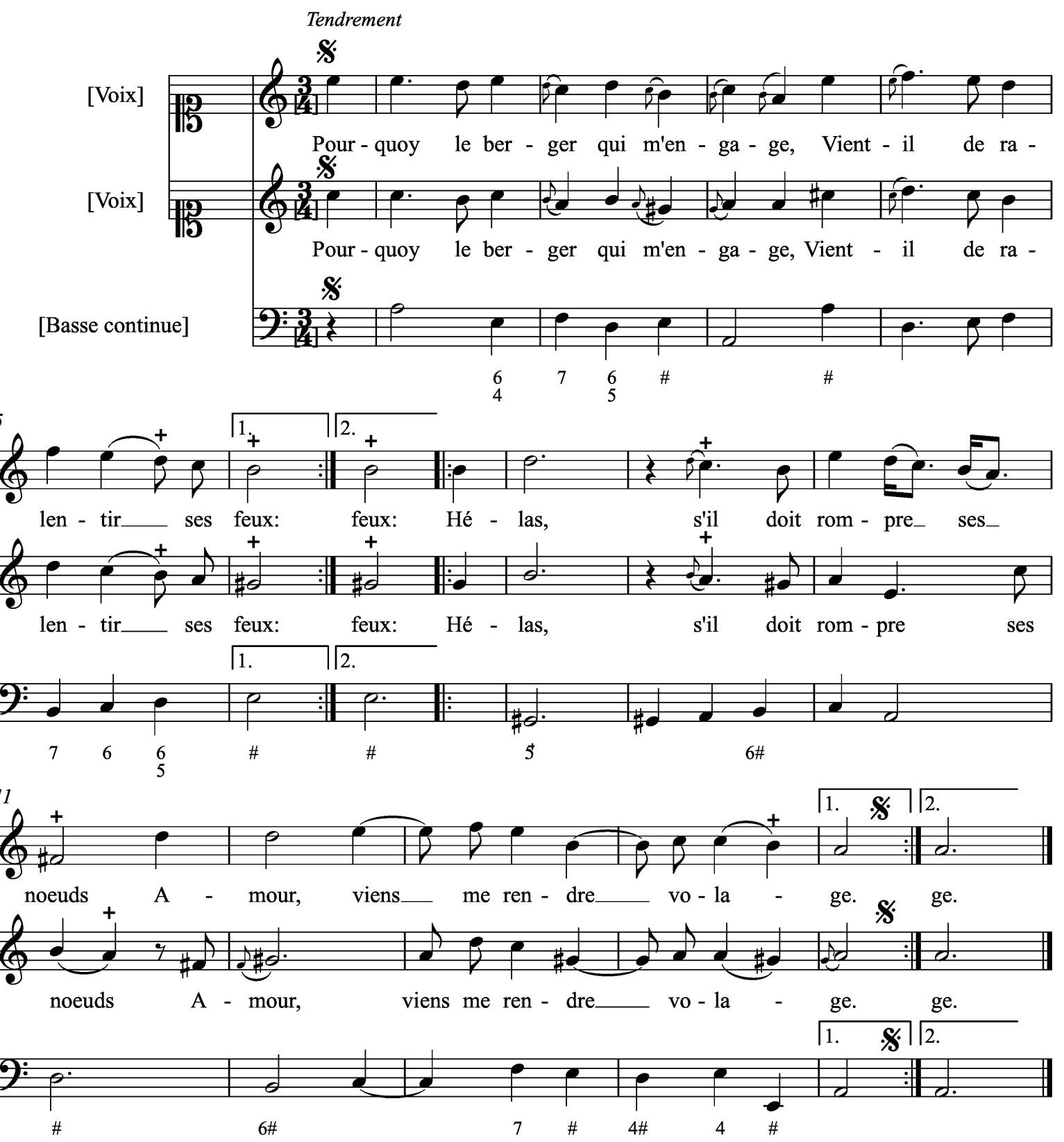

Deuxième couplet

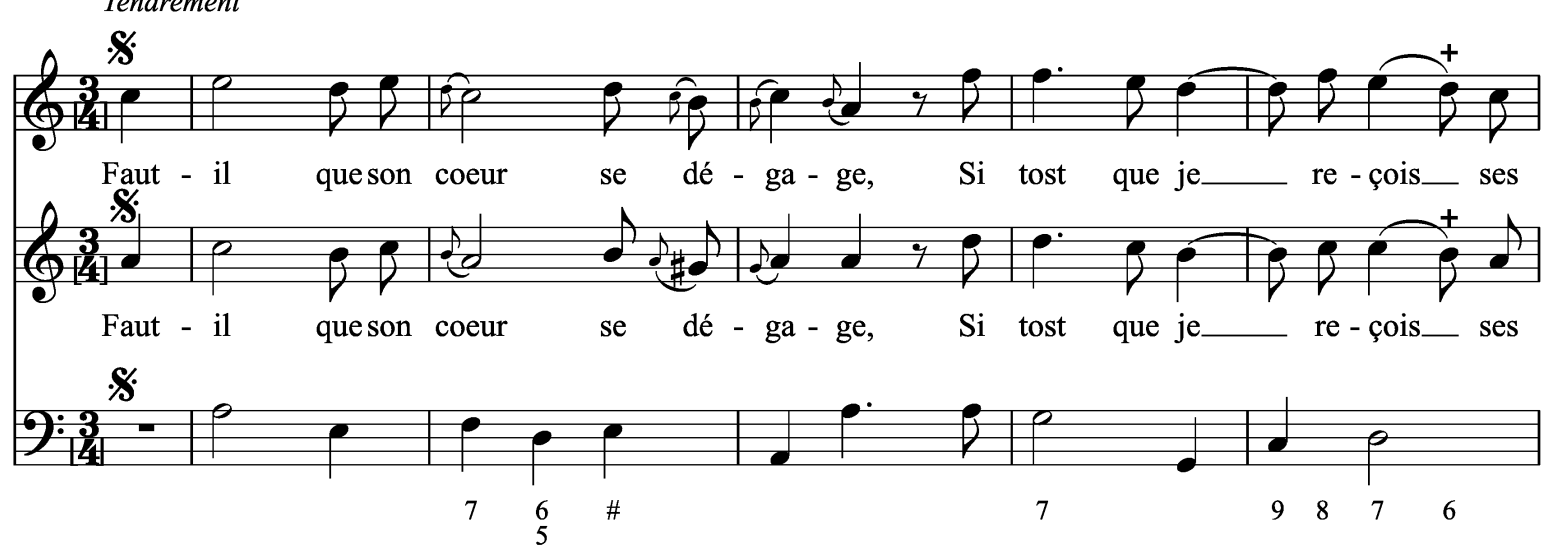



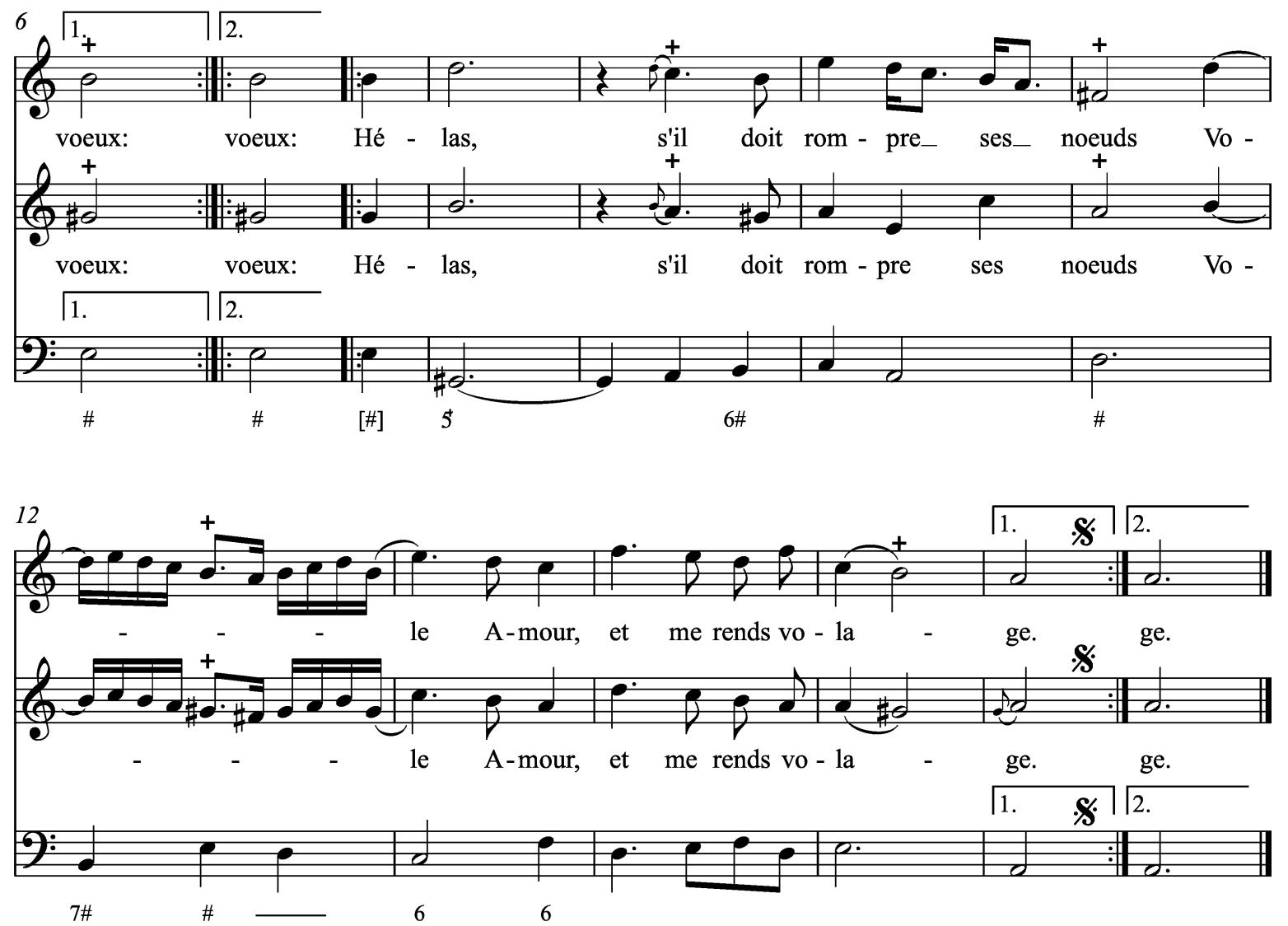

\section{Troisième couplet}
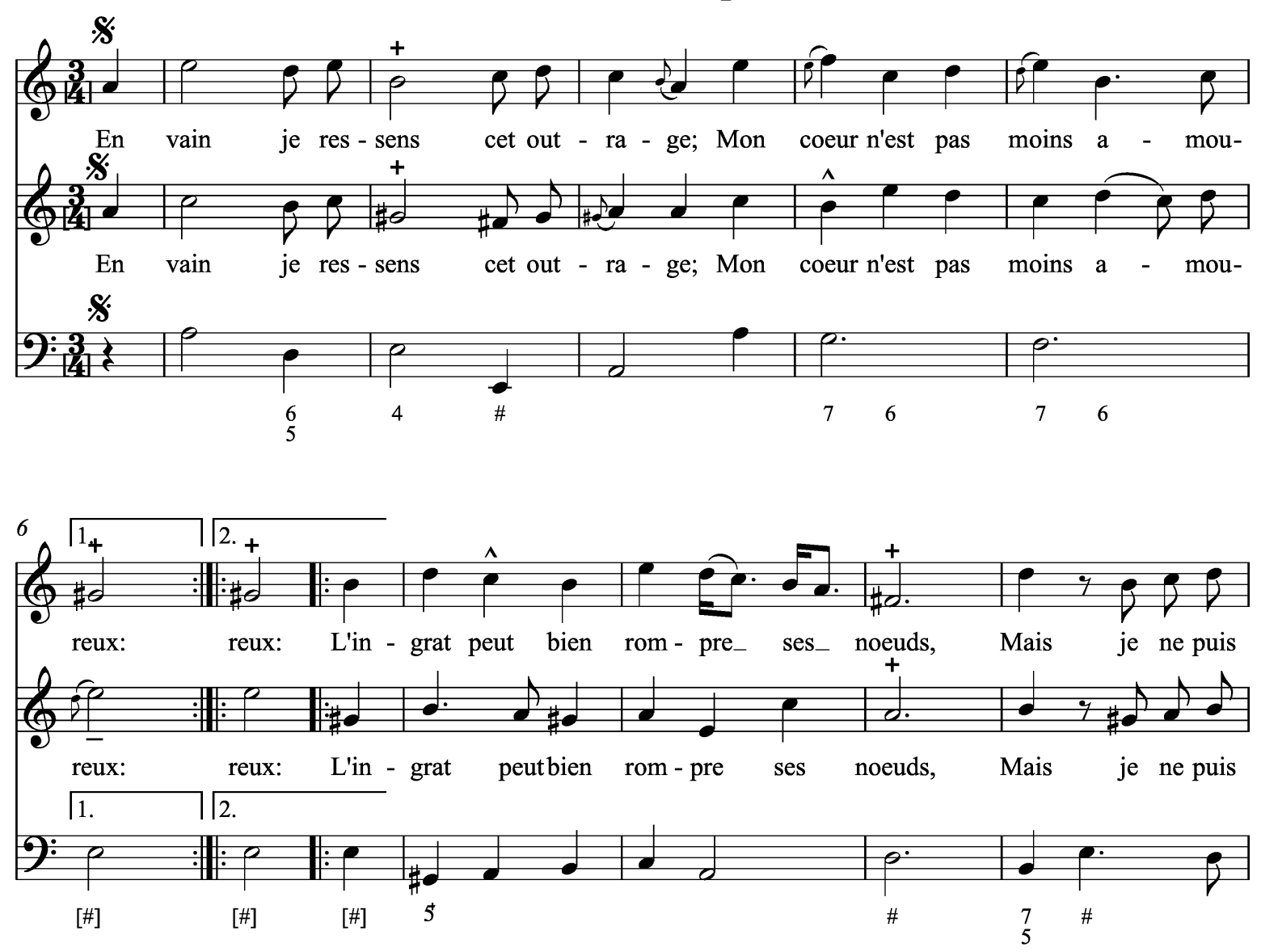


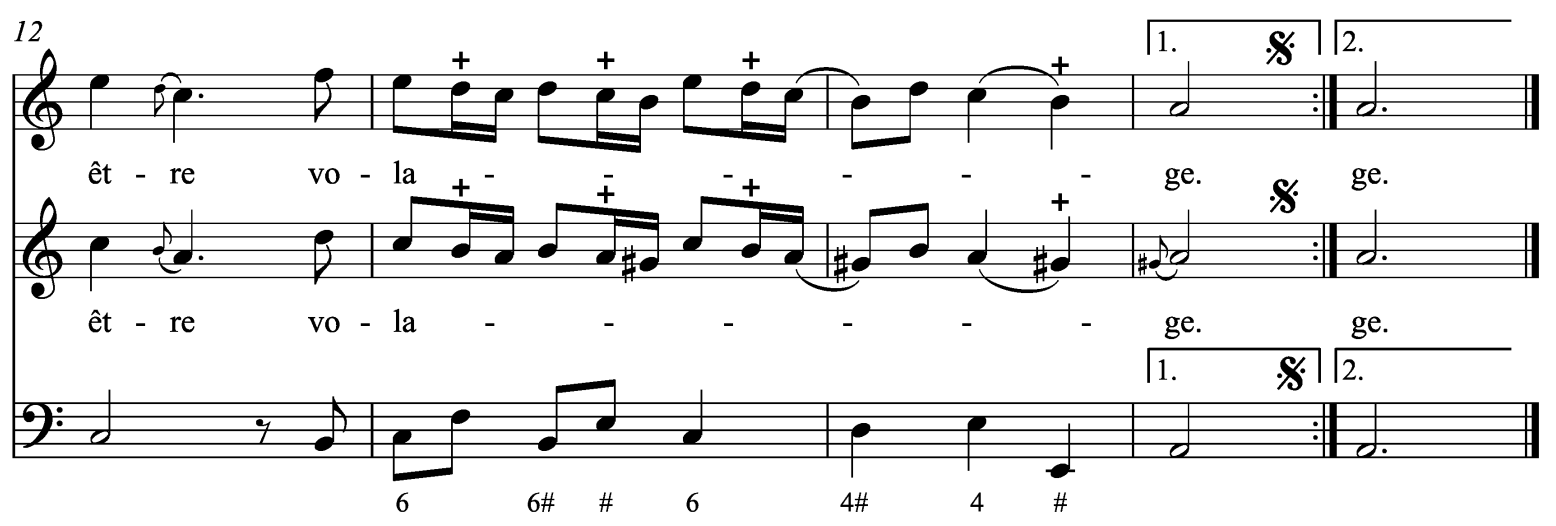




\section{Trop longtems a Bacchus}

Air à boire Duo
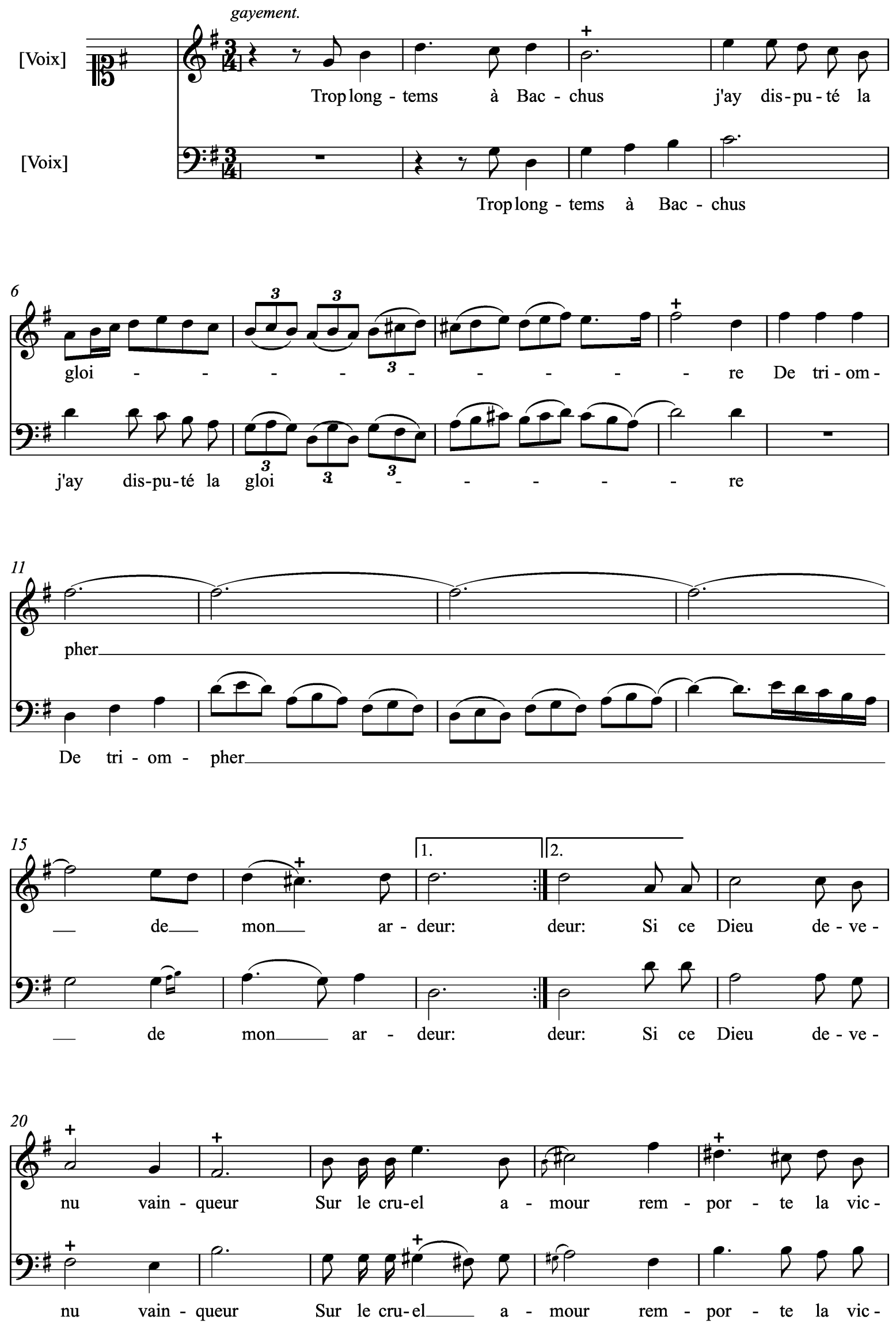

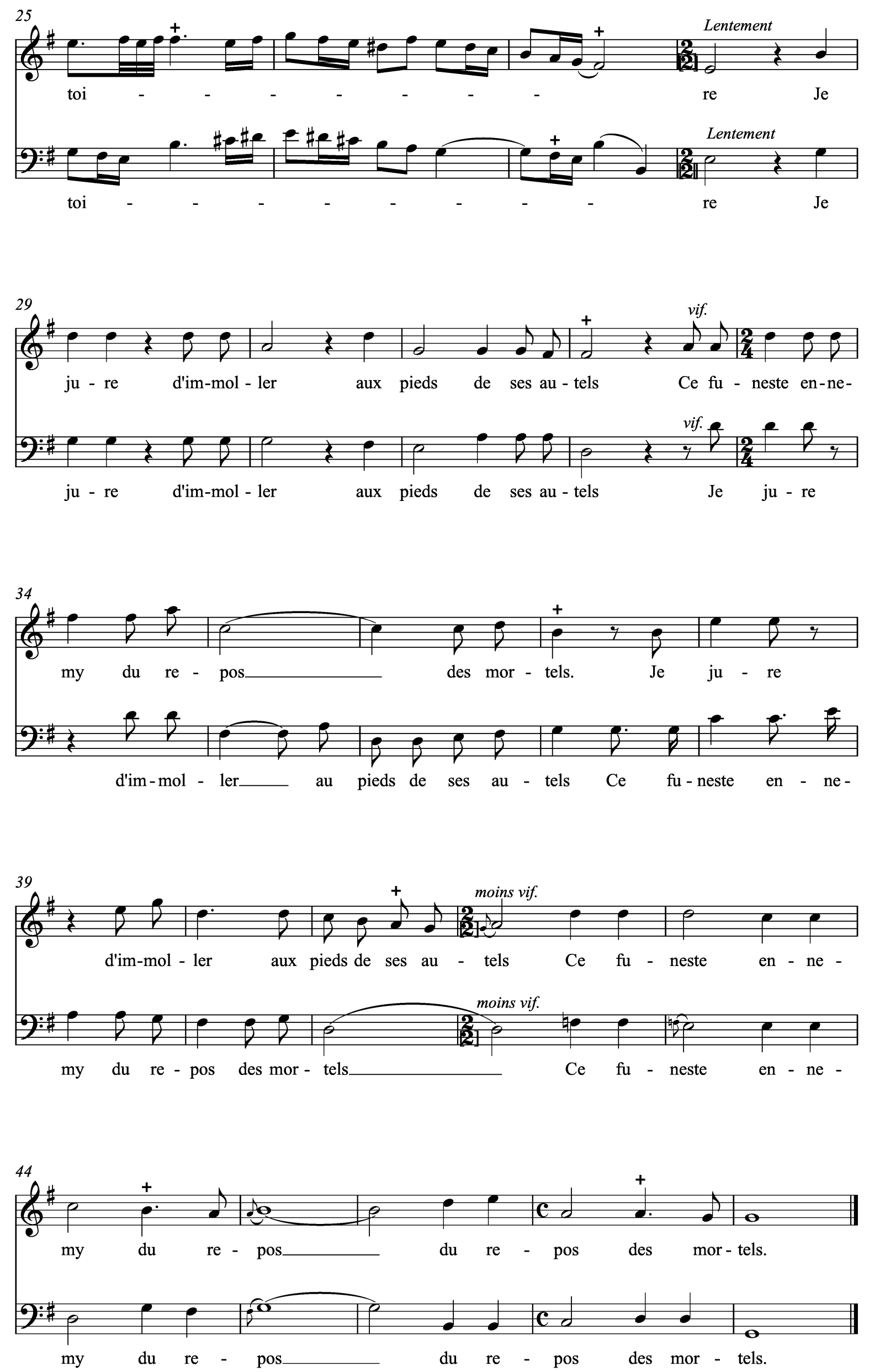


\section{Le Printems}

Cantatille
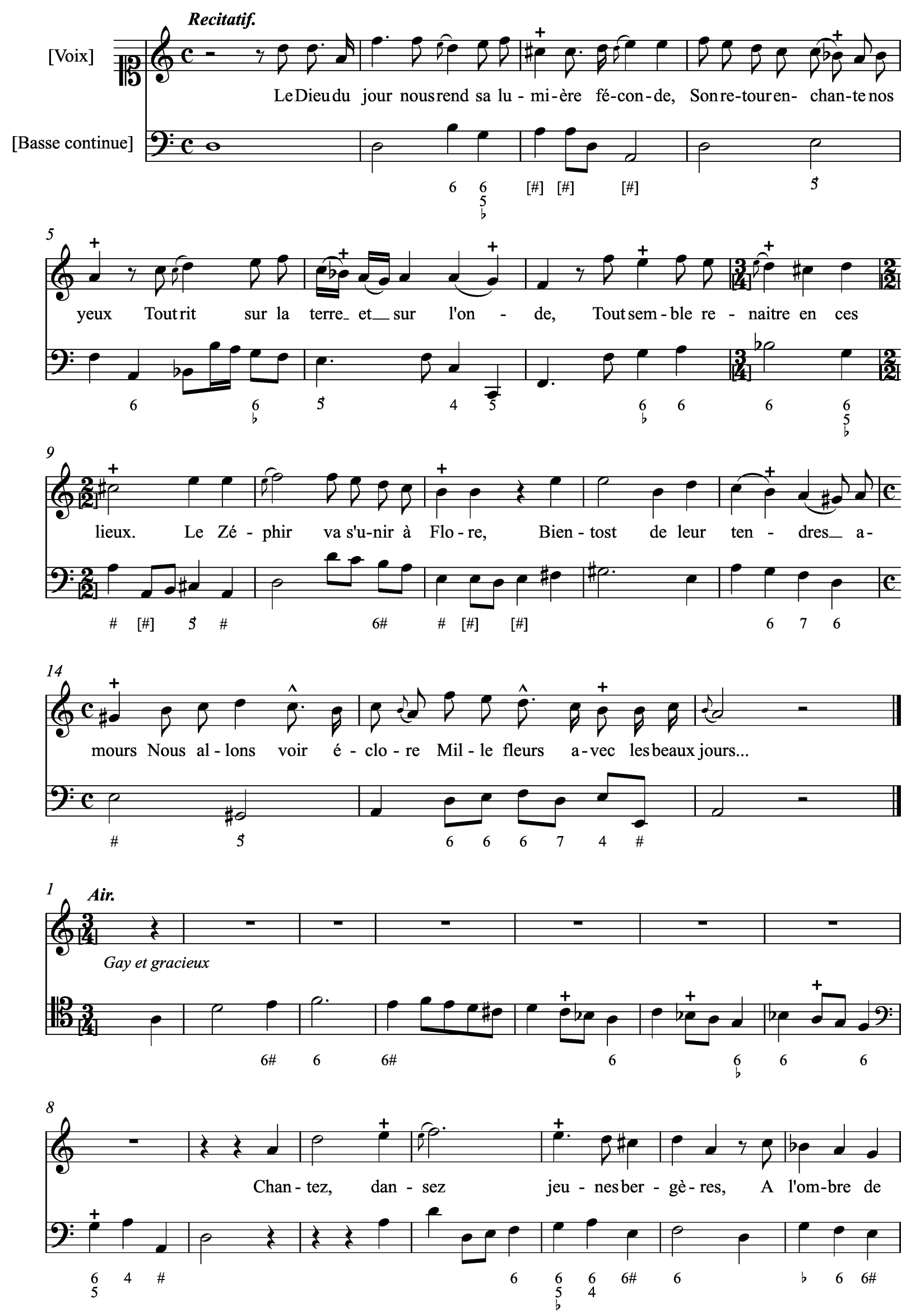

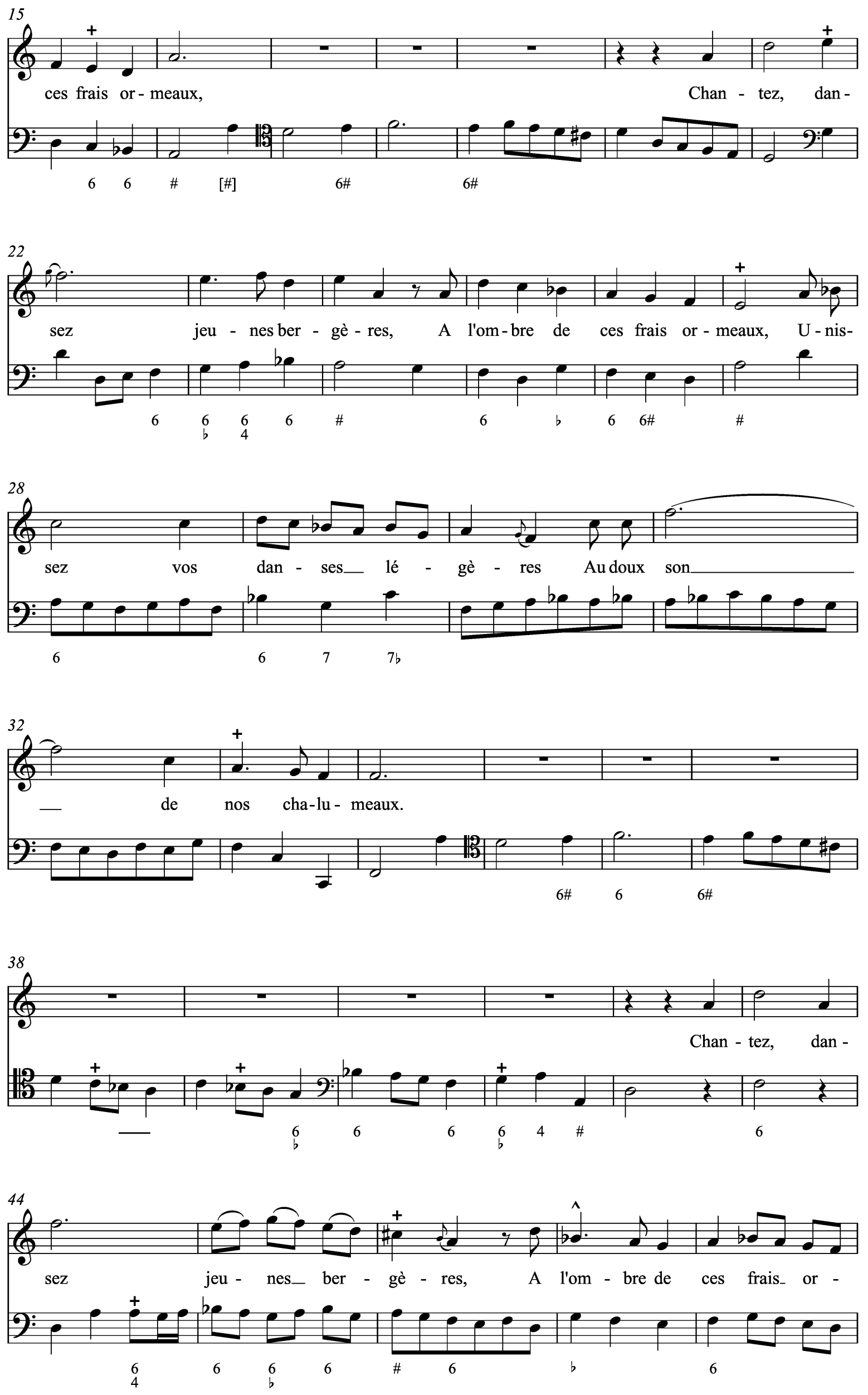

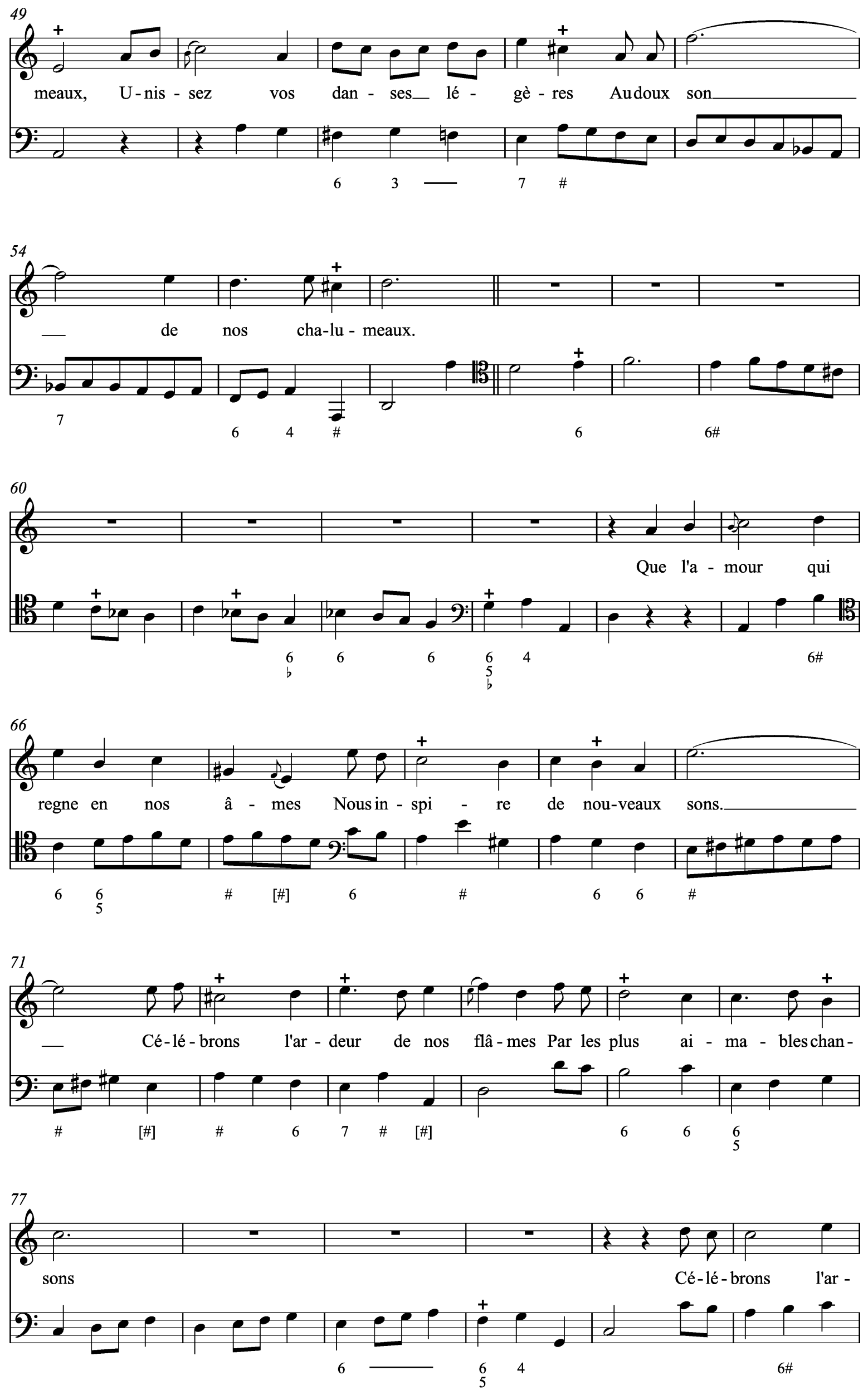

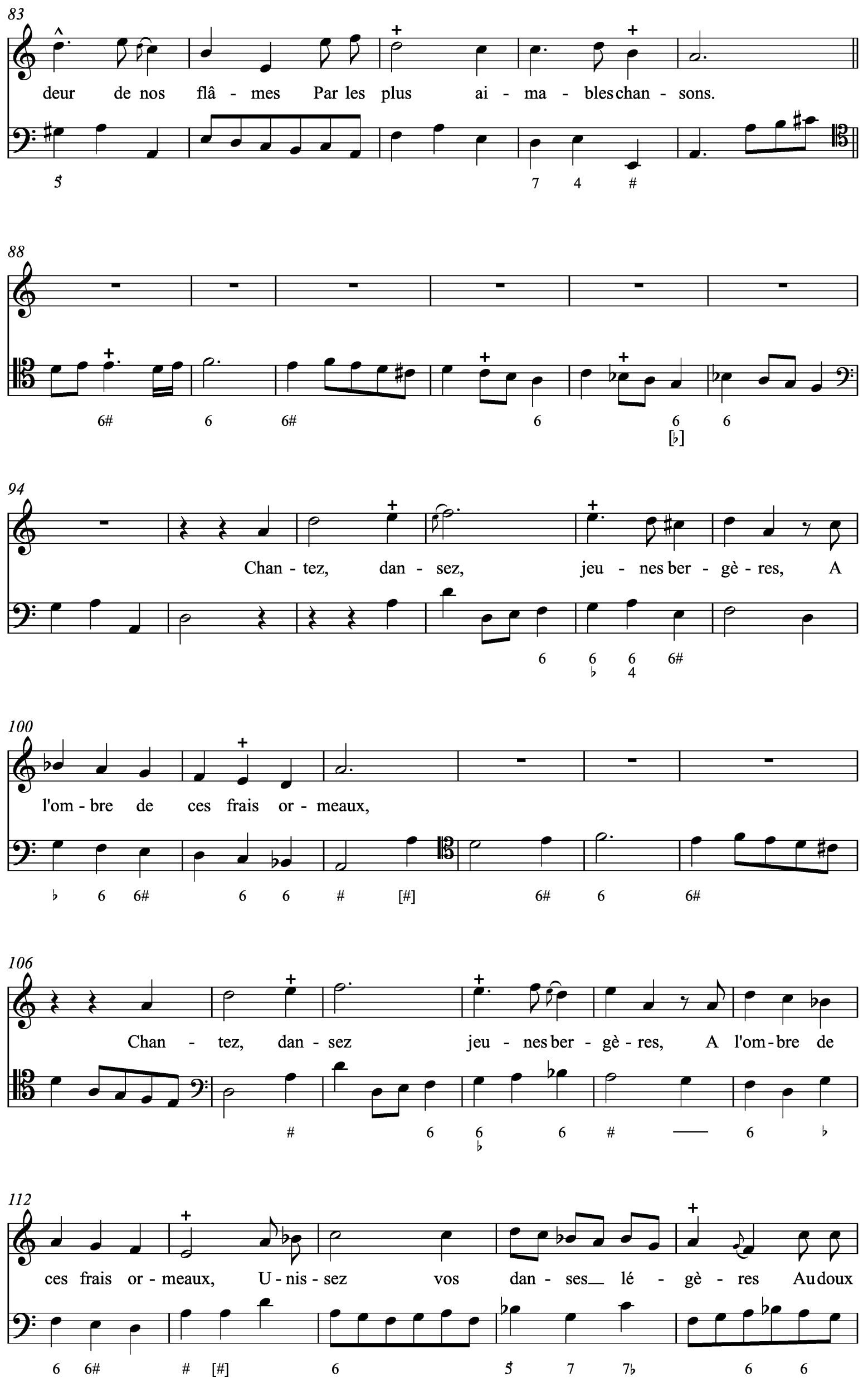

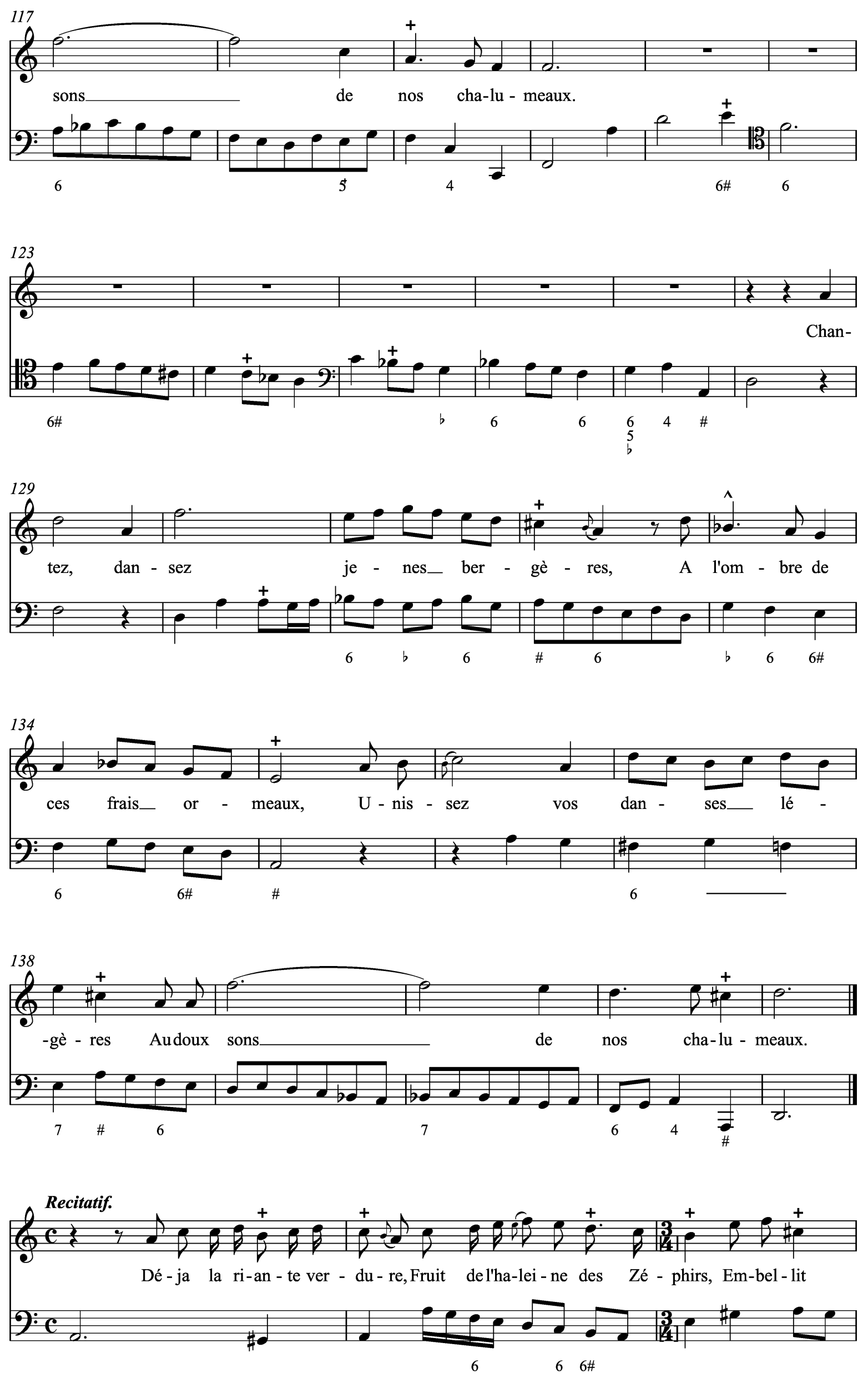


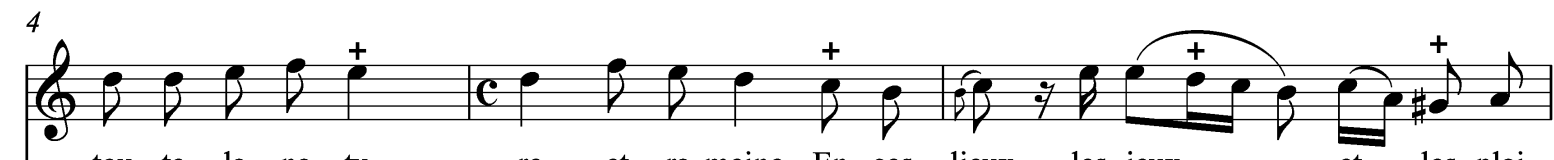
tou - te la na-tu $\quad$ re, et ra-meine En ces lieux les jeux_ les plai-
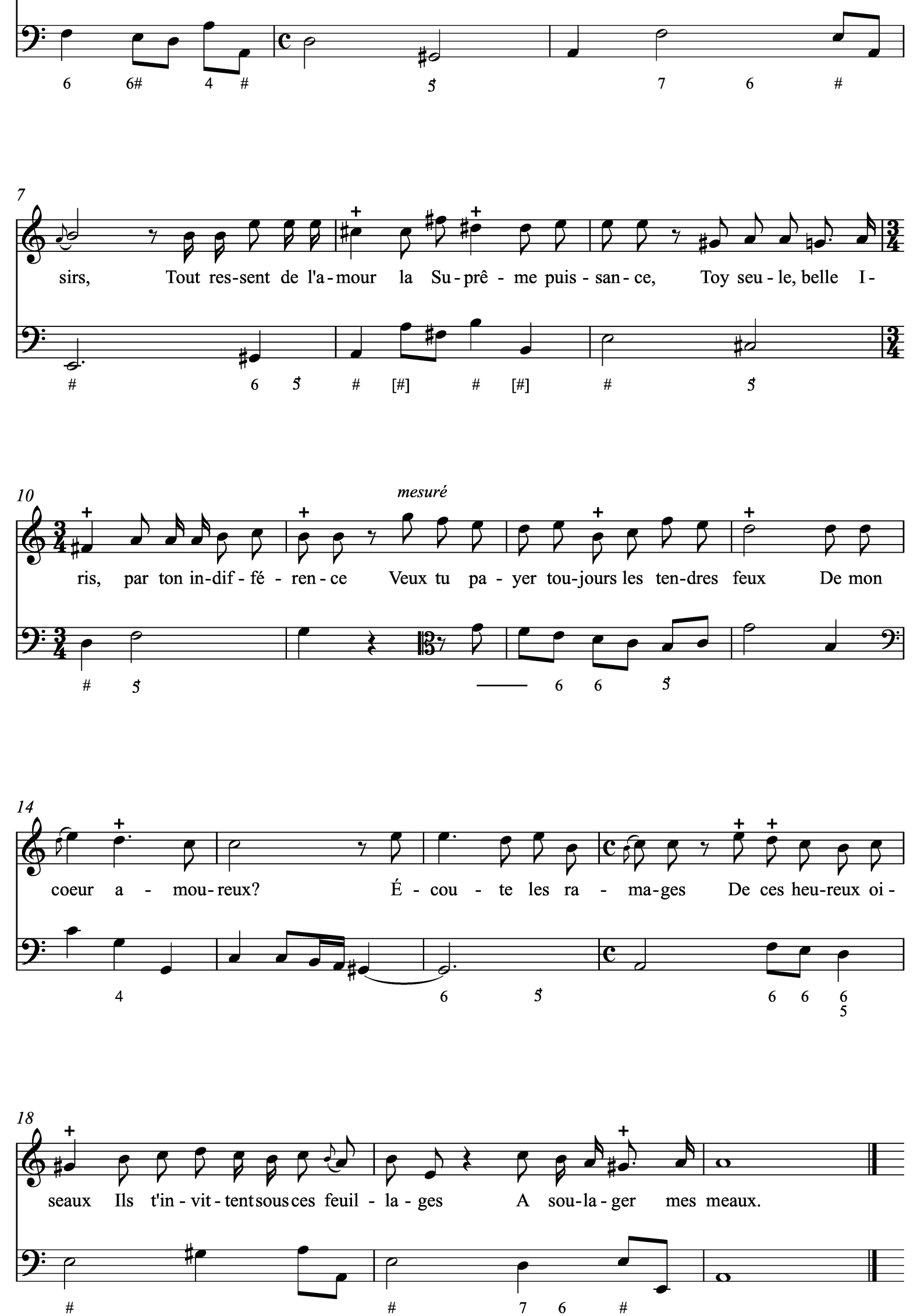

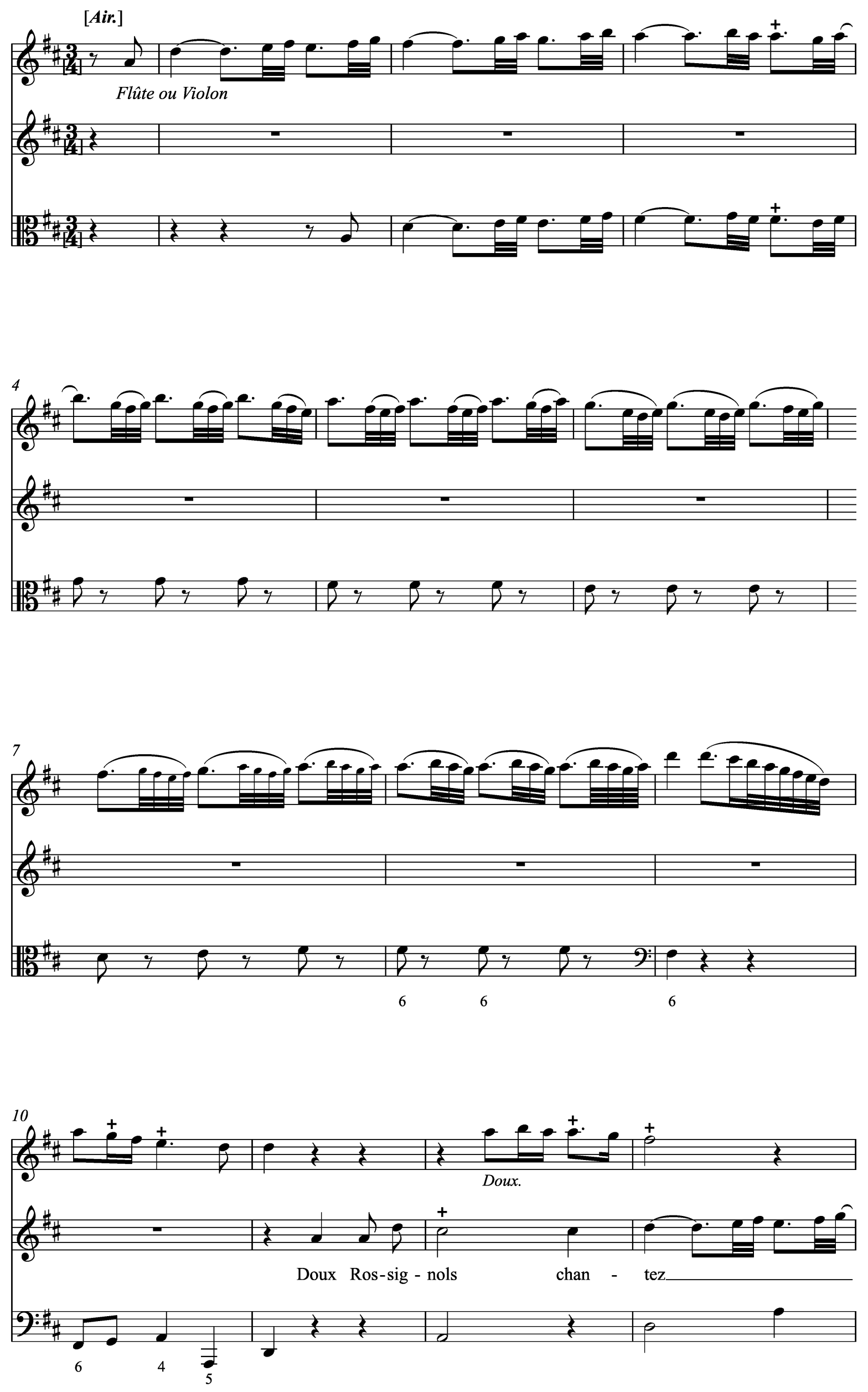

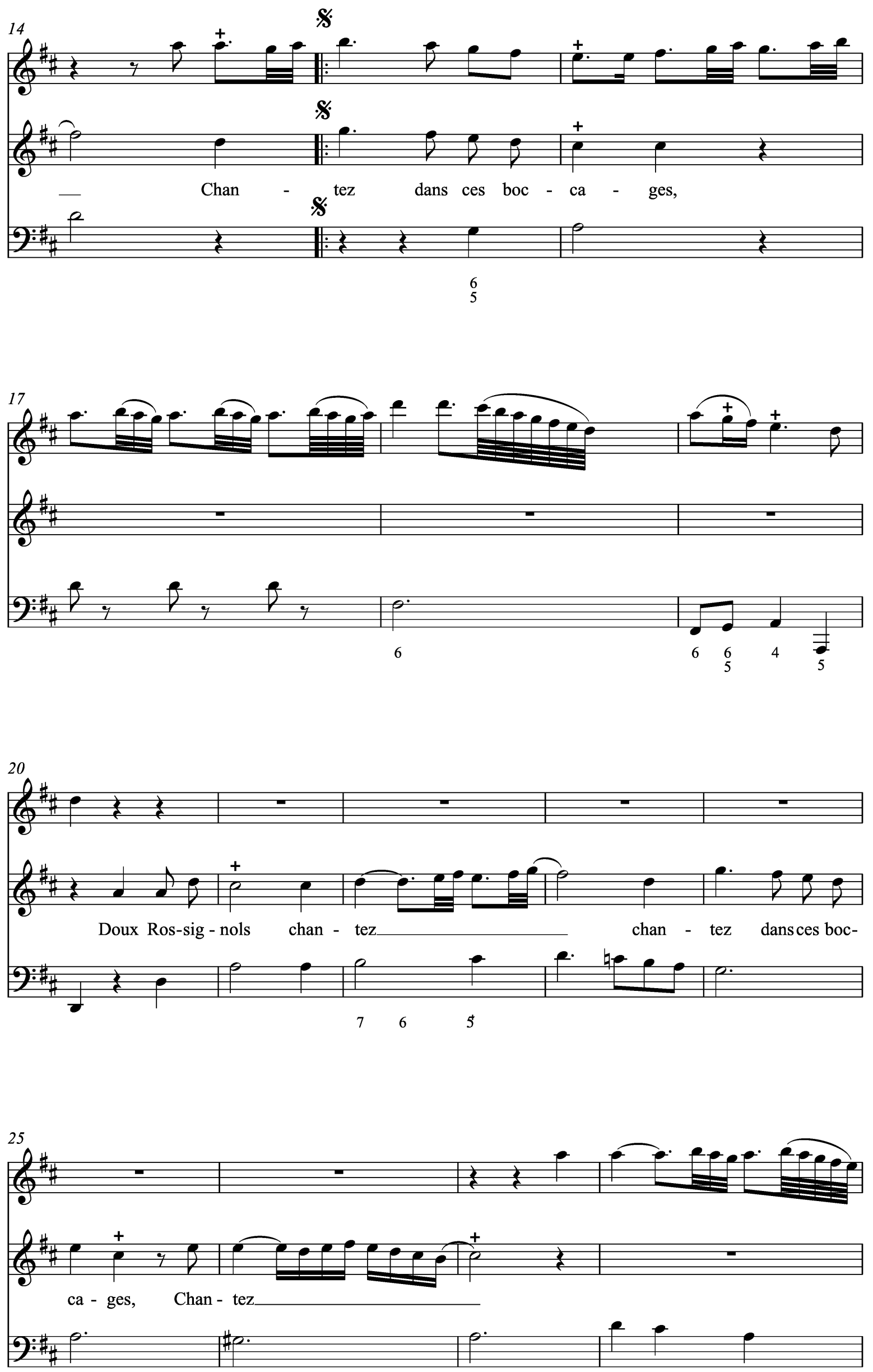

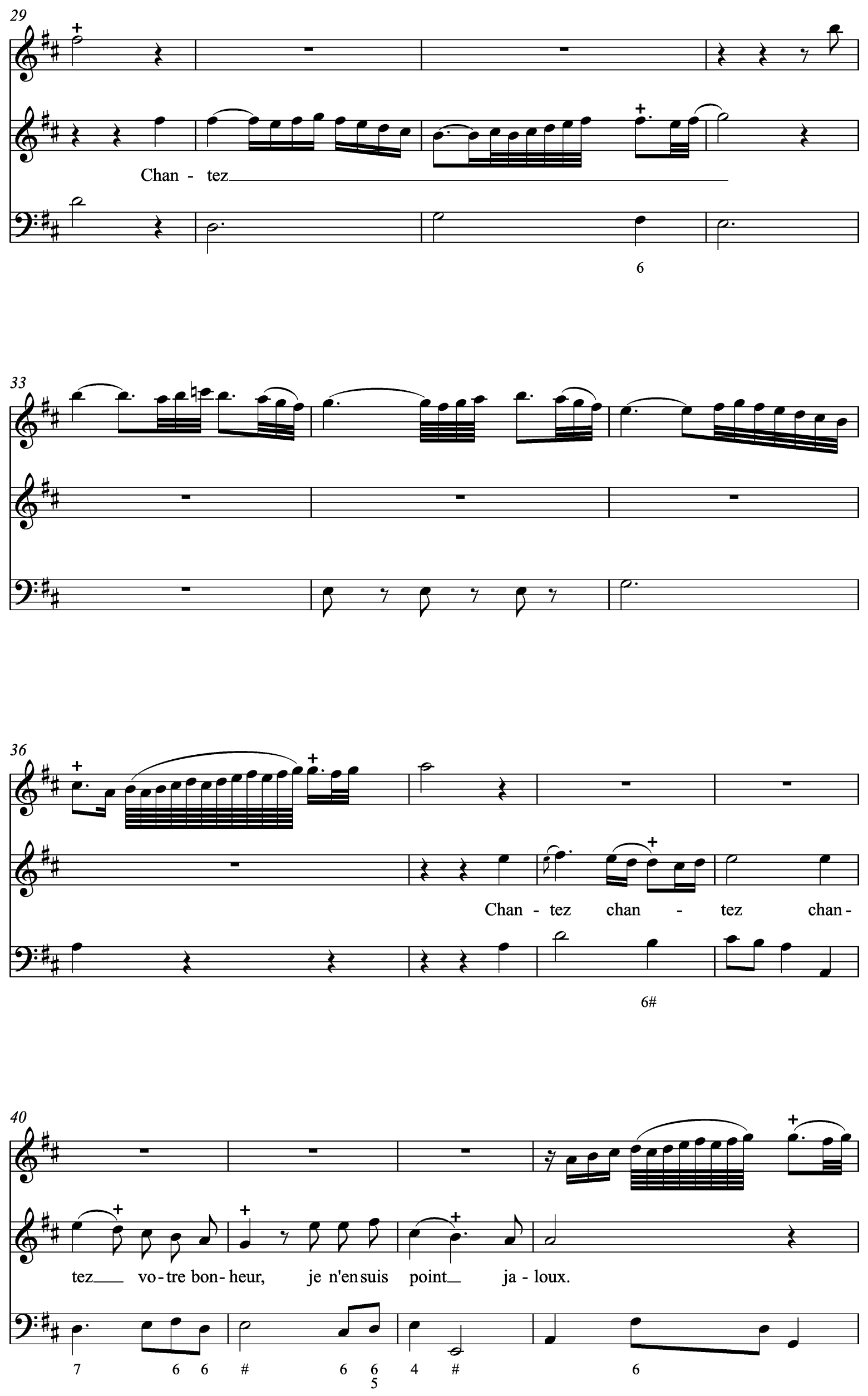

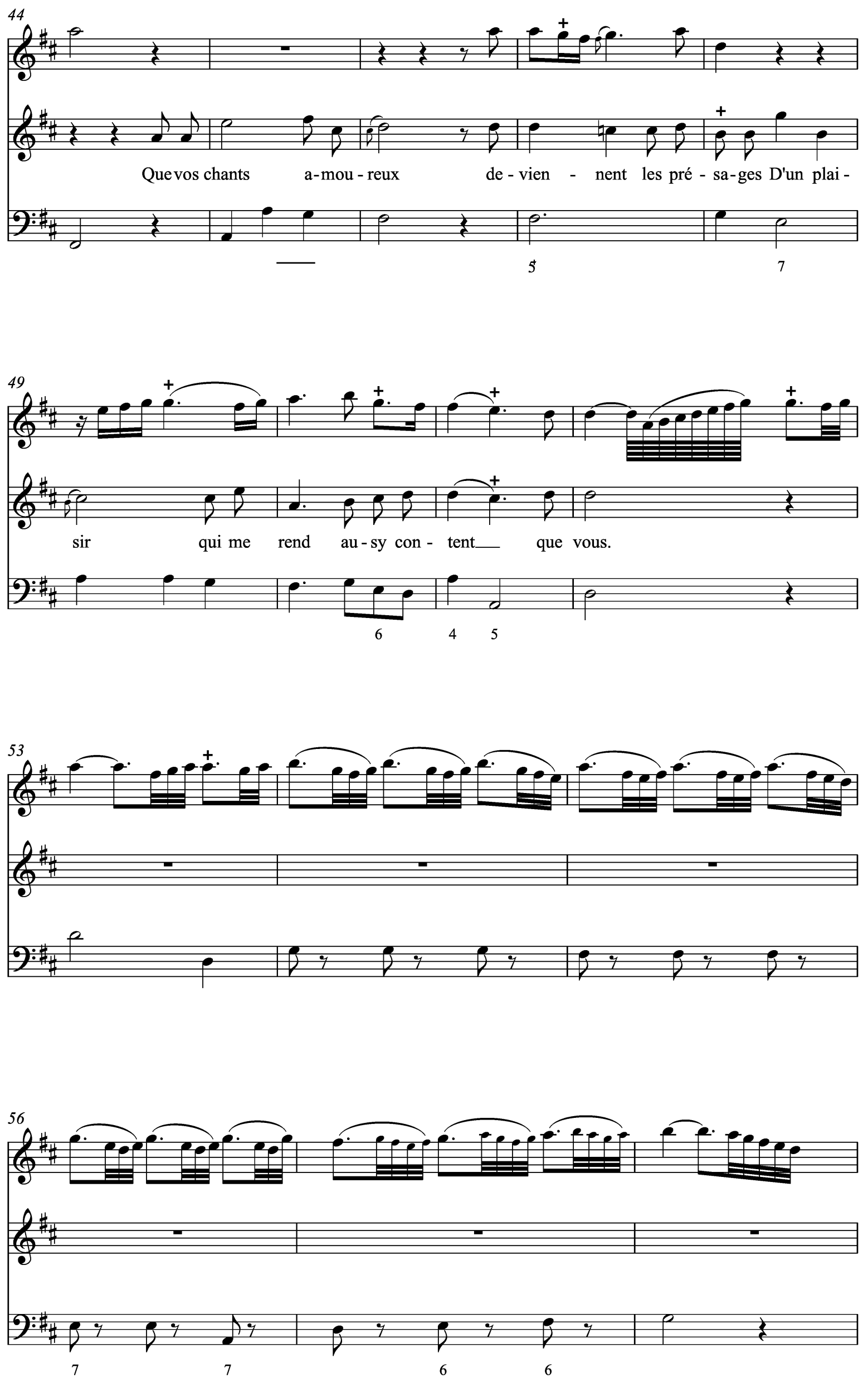

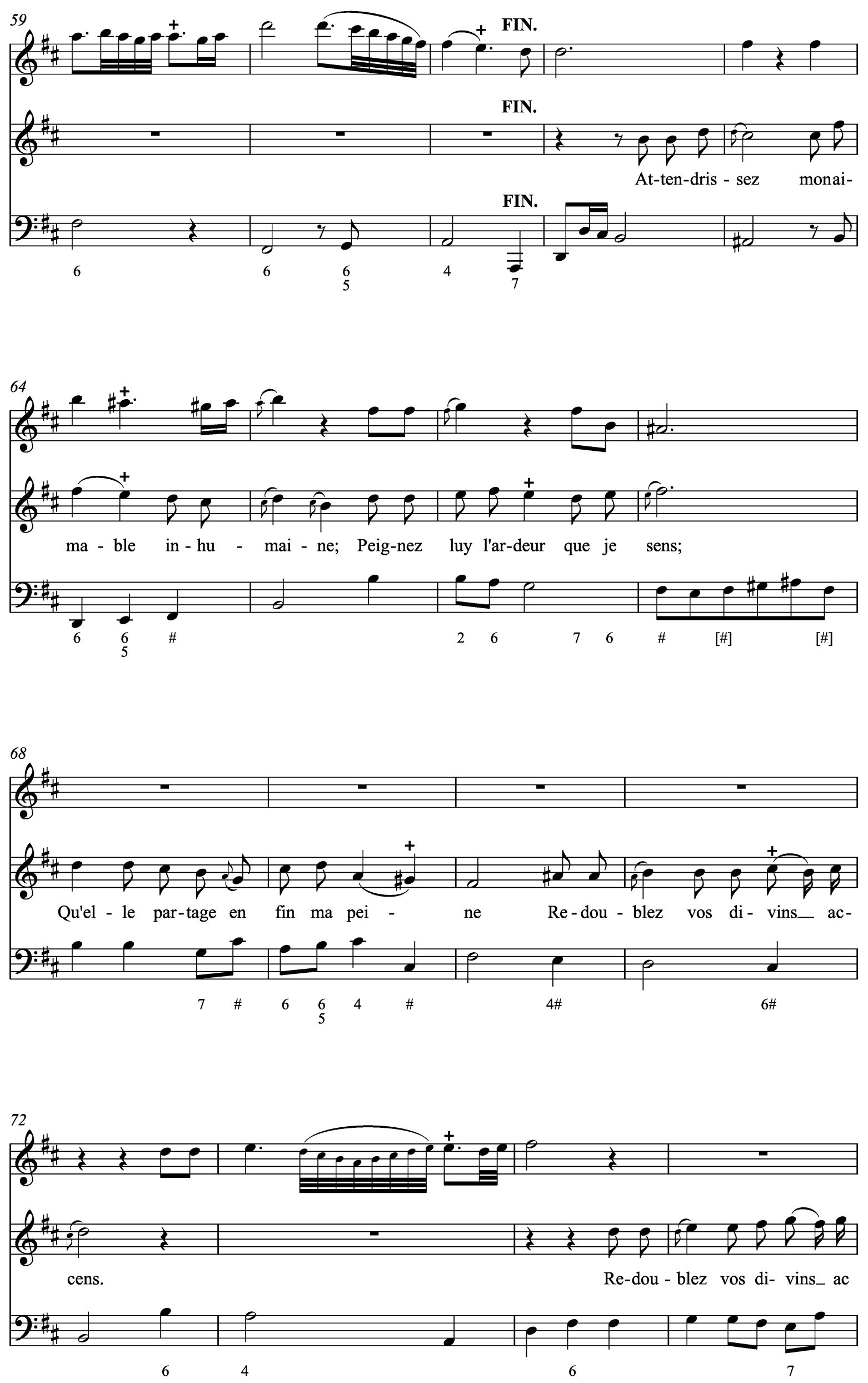

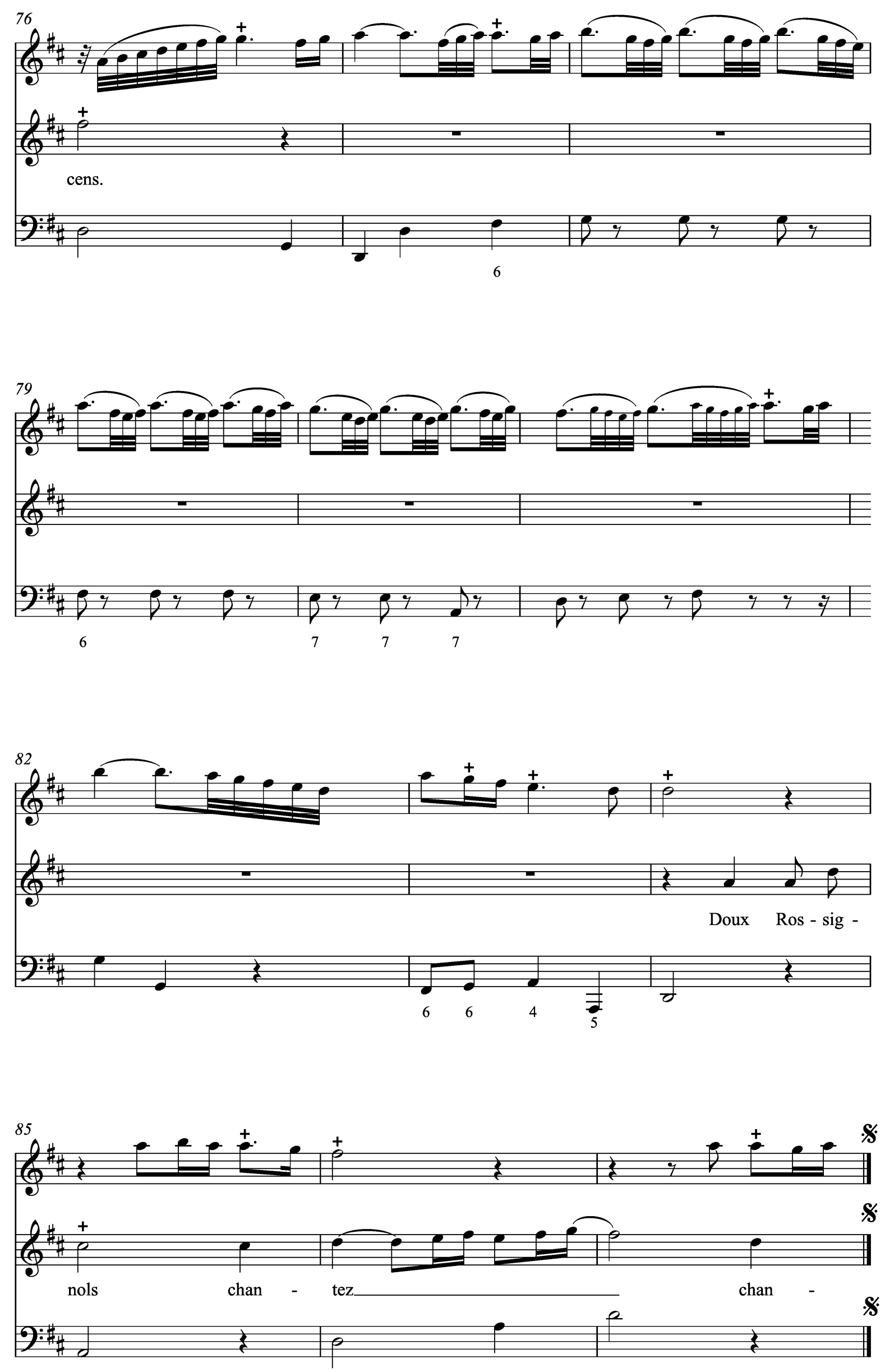


\section{Que les mortels sont misérables}

Récit de basse
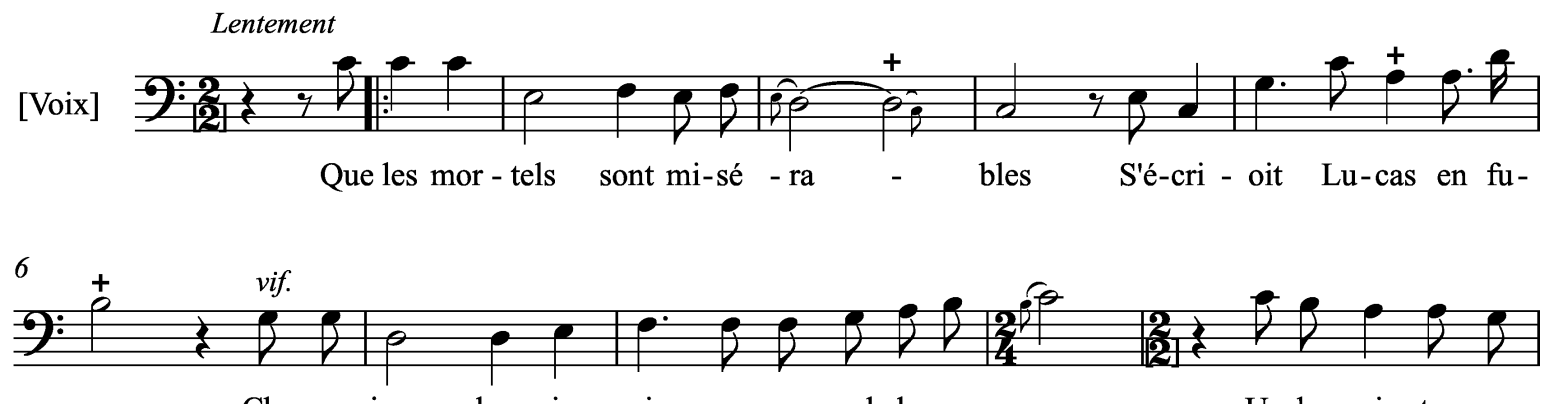

eur, Cha-que jour leur in - spire une nou-vel-le er - reur Undes-sein tra-ver-
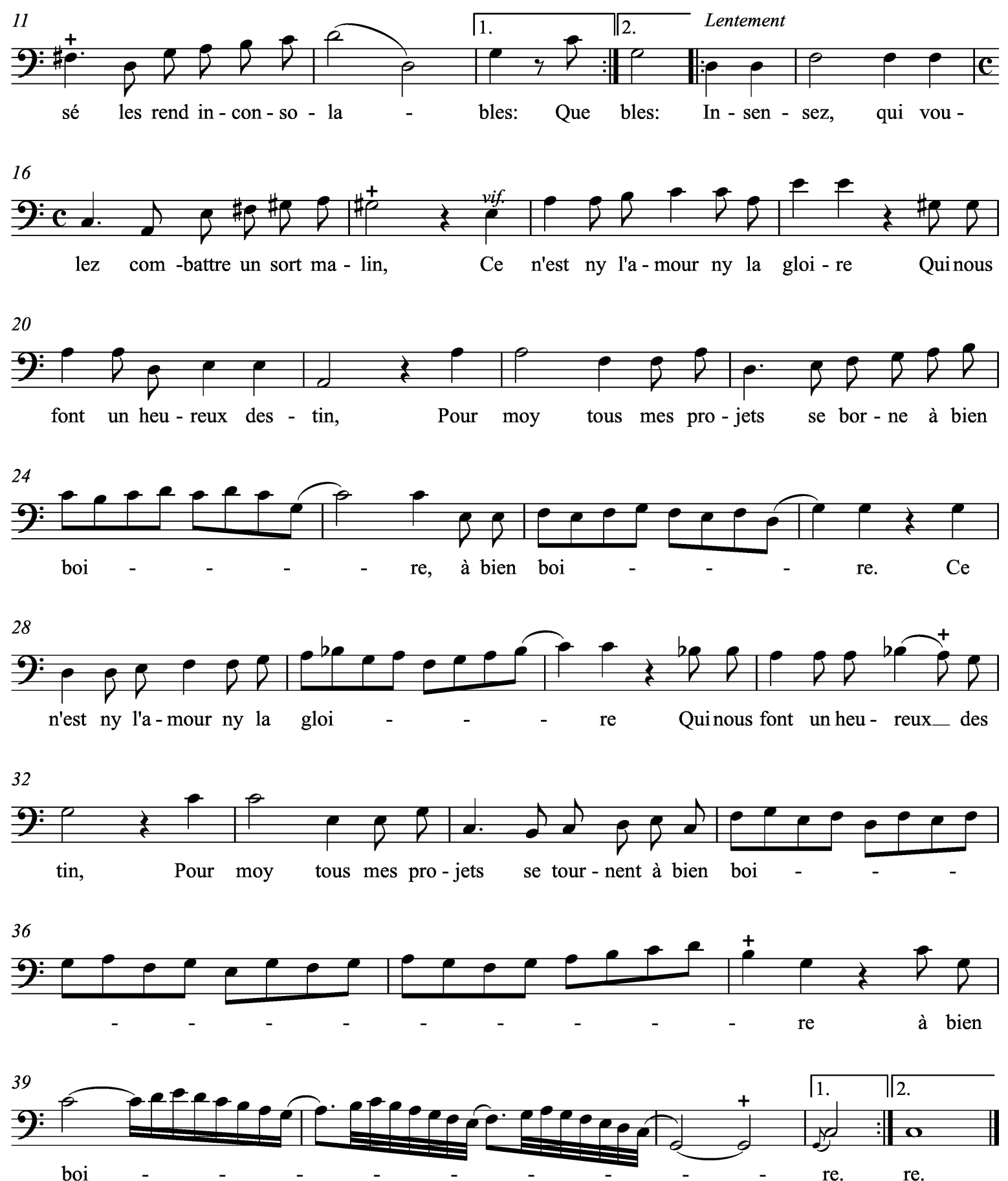


\section{De richésses amy je ne suis point jaloux}

Air sérieux

[Voix]
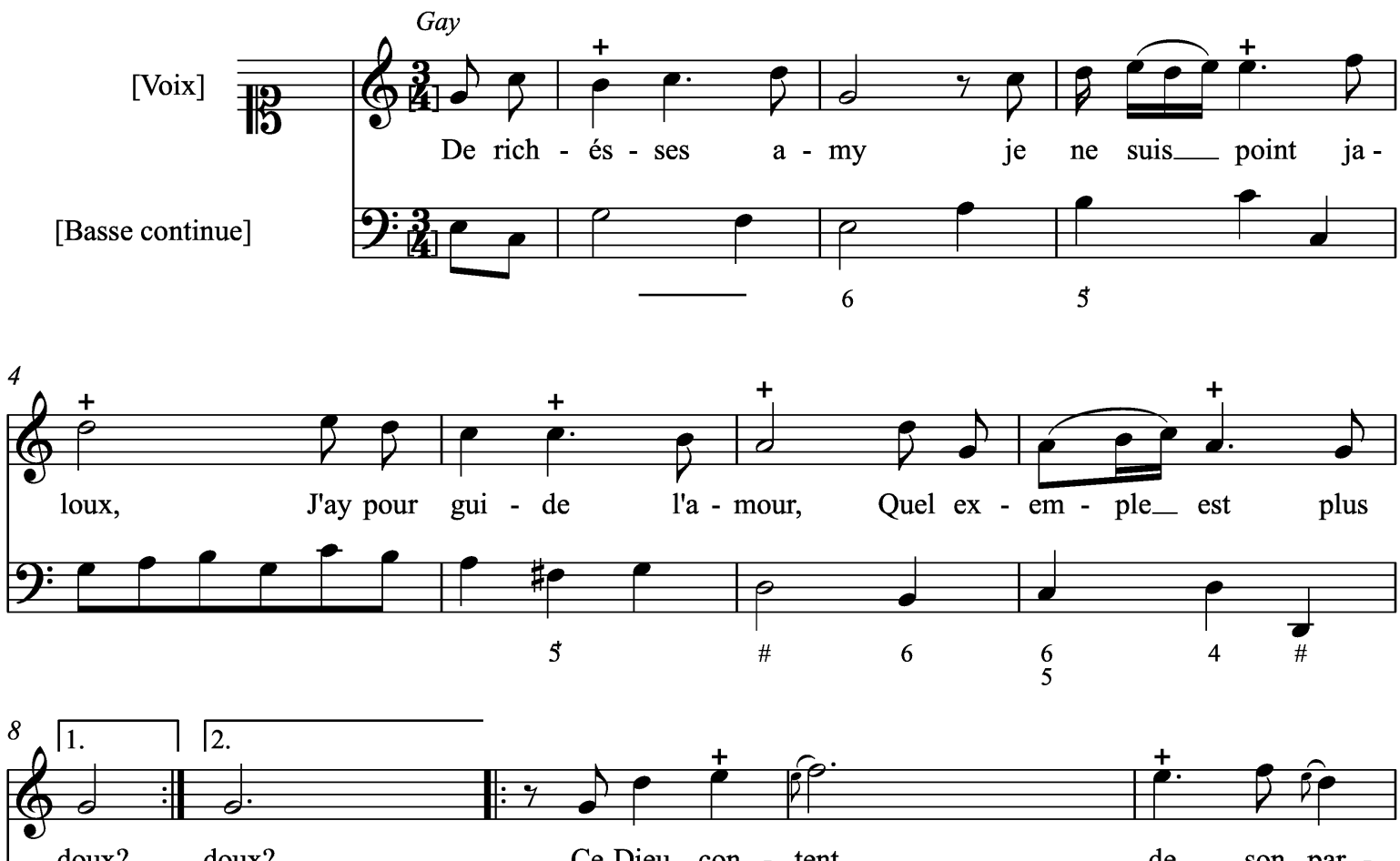
doux?
Ce Dieu, con - tent
de son par -

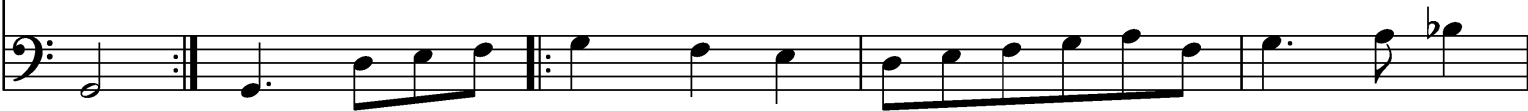

$6 \#$

13

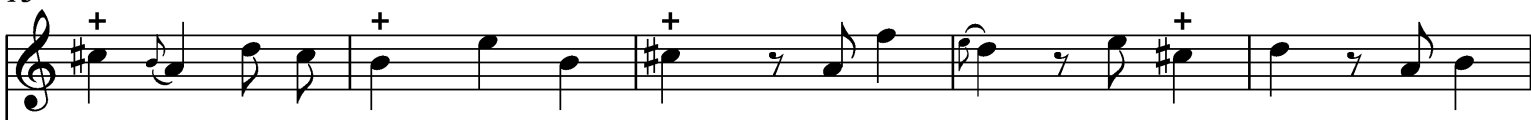

ta - ge, N'apour bien qu'un car - quois, Des fle - ches un flam - beau, Sa - tis -
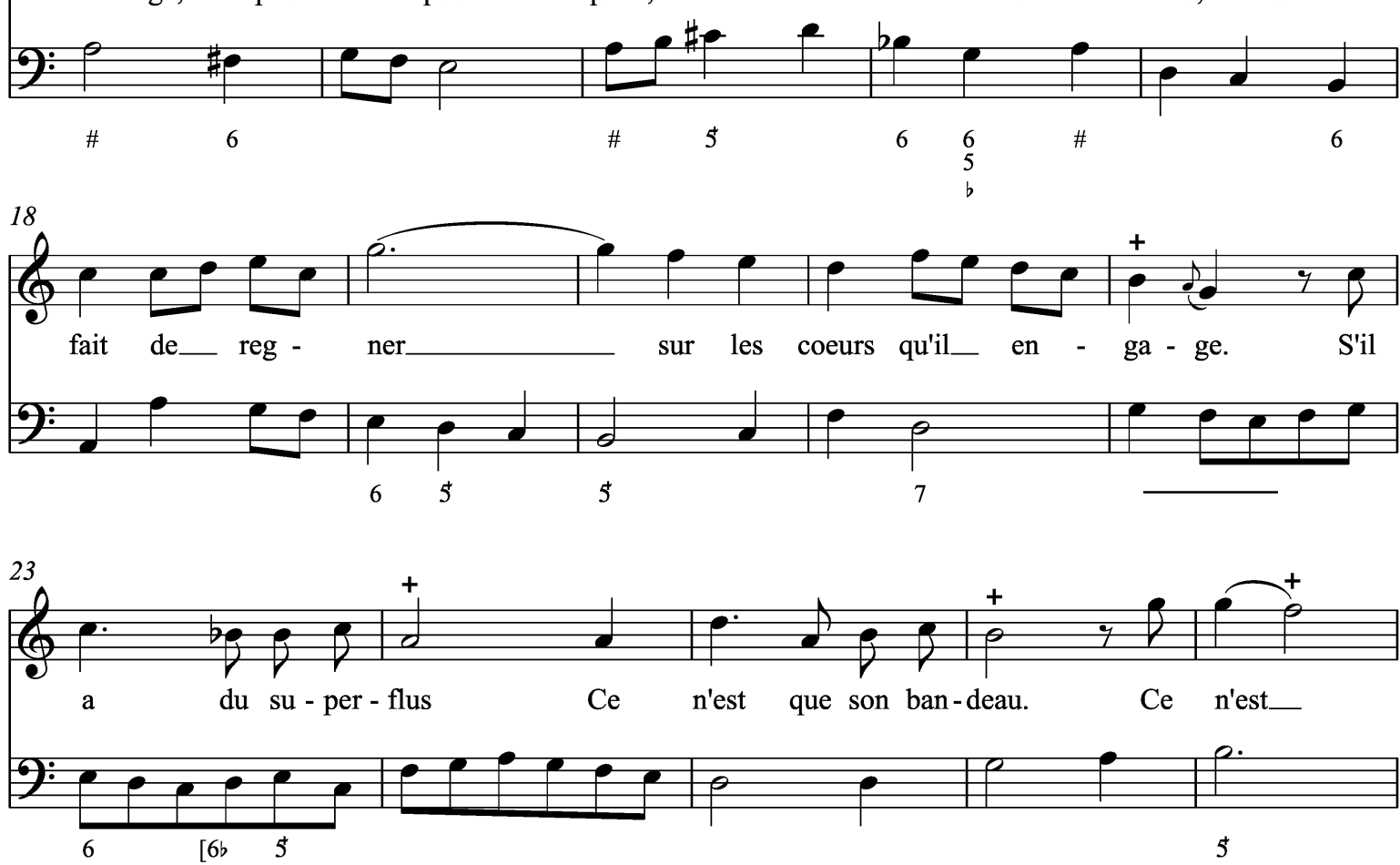


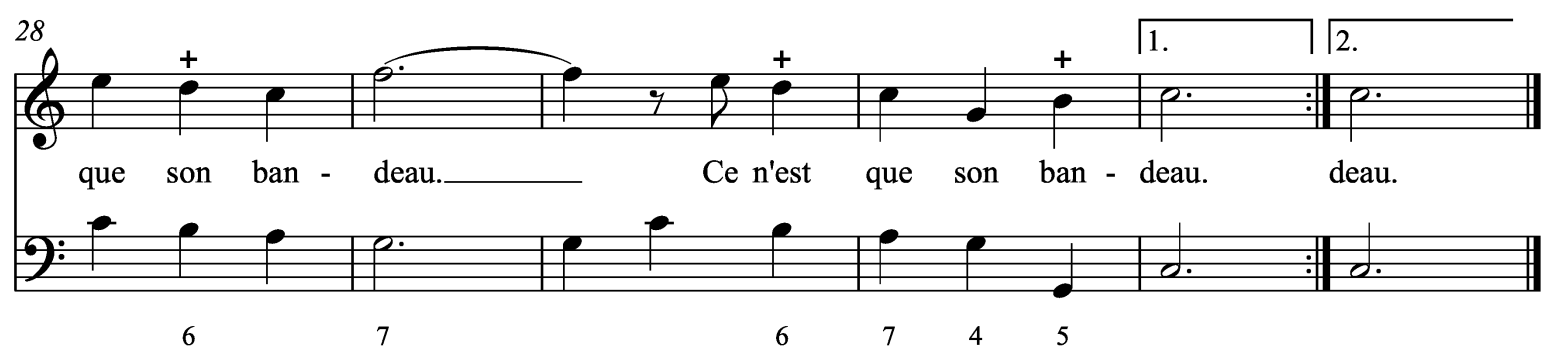




\section{Pour guérir sans retour la plus vive bléssure}

Récit de basse

[Voix]

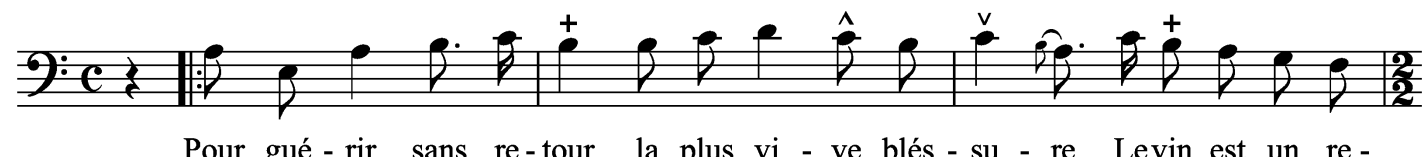

Pour gué - rir sans re-tour la plus vi - ve blés - su - re Levin est un re -
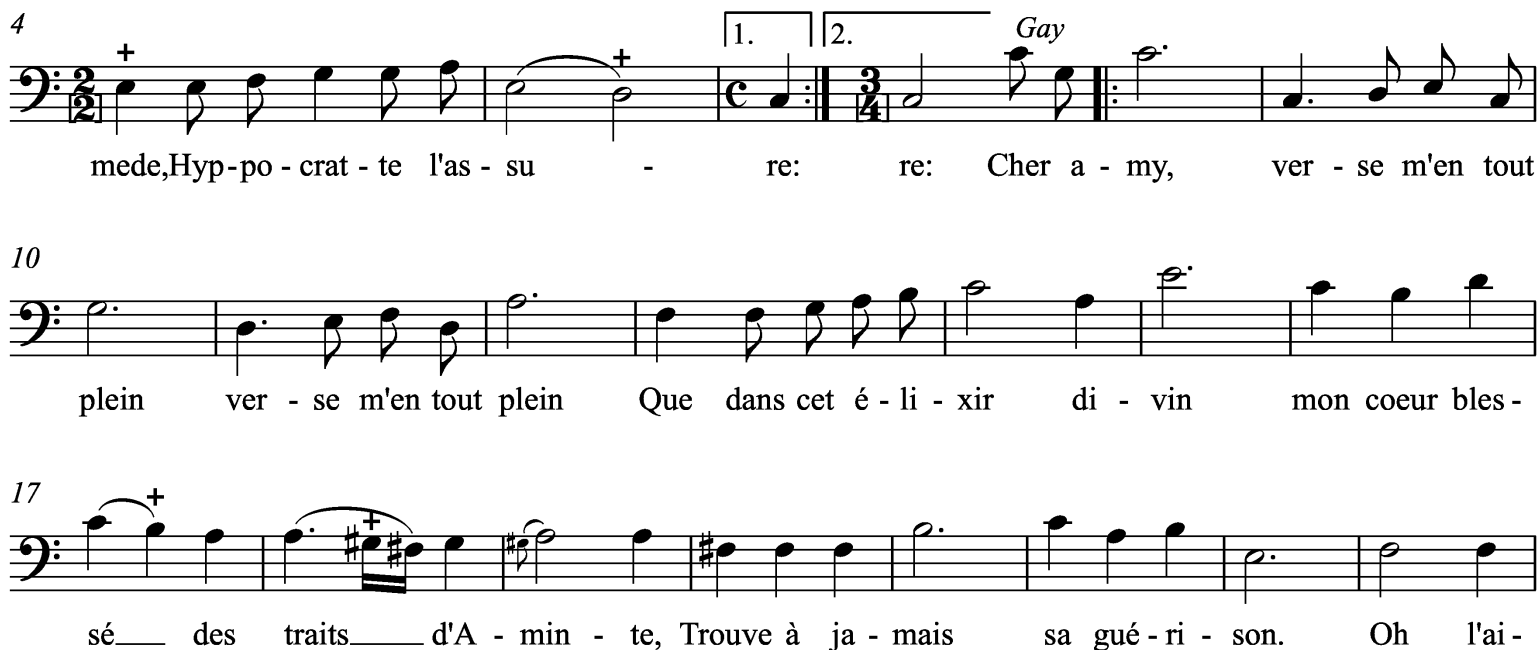

25
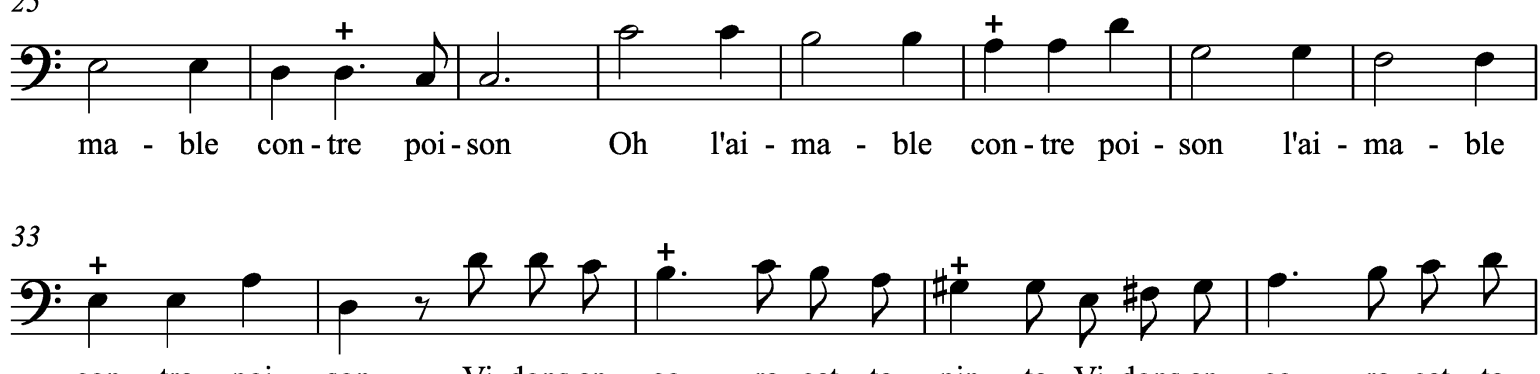

con - tre poi - son, Vi-dons en - co - re cet - te pin - te. Vi-dons en - co - re cet - te

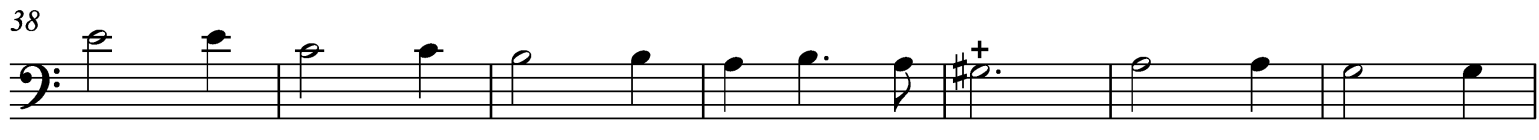

pin - te. Oh l'ai - ma - ble con - tre poi - son, $\quad$ Oh l'ai - ma - ble

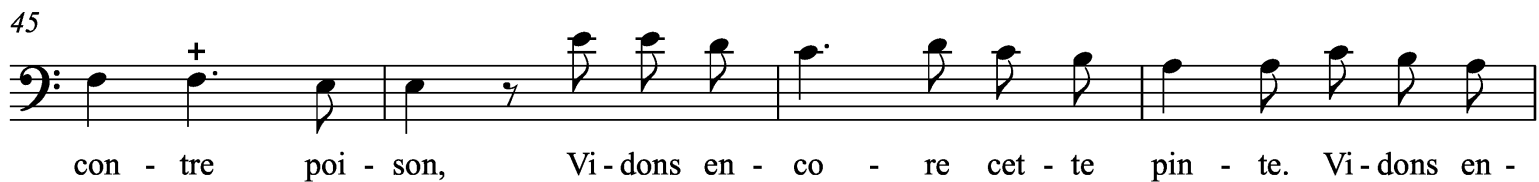

49
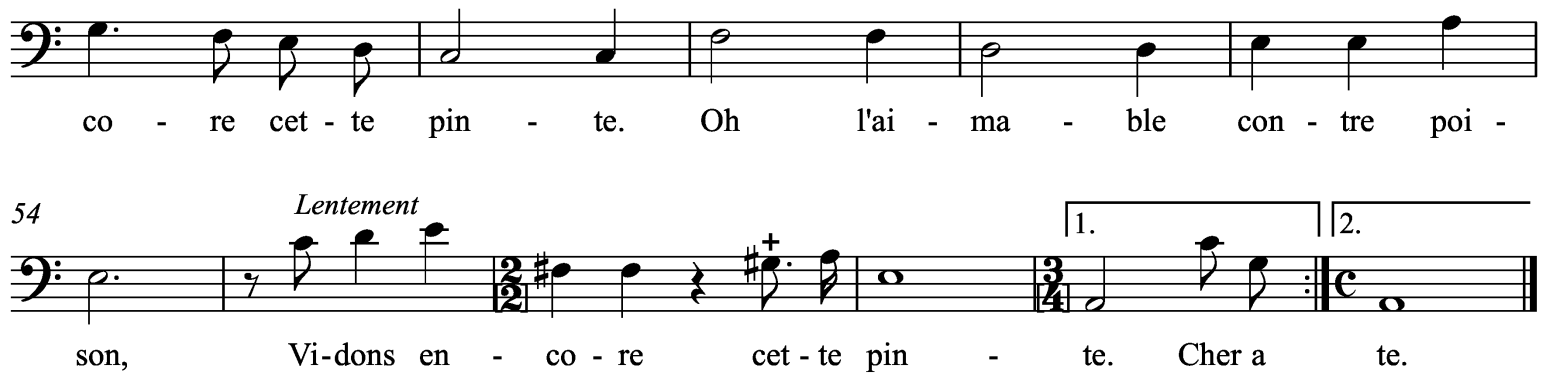


\section{Dieu du vin qu'elle est donc ta fatalle puissance}

Air à boire

[Voix]
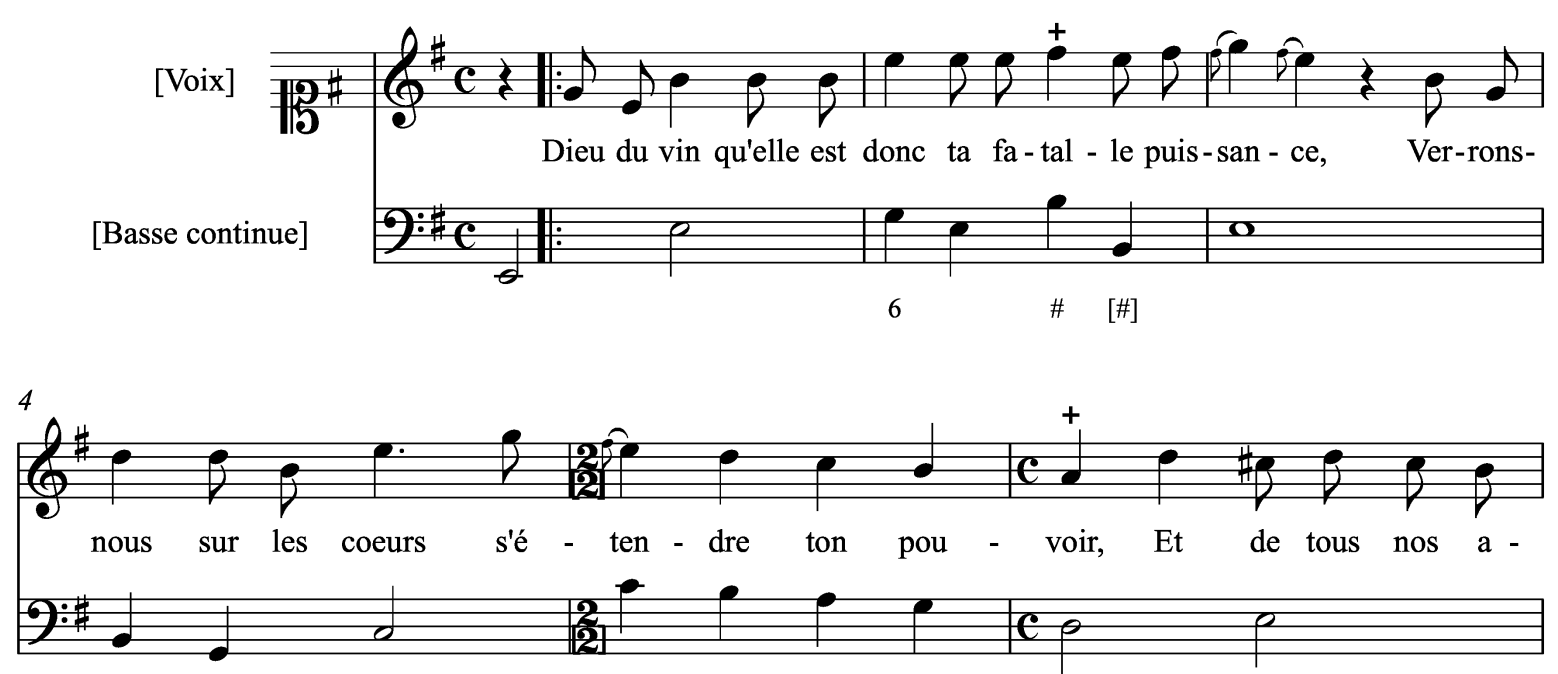

6

$6 \quad 6$

$6 \#$
5
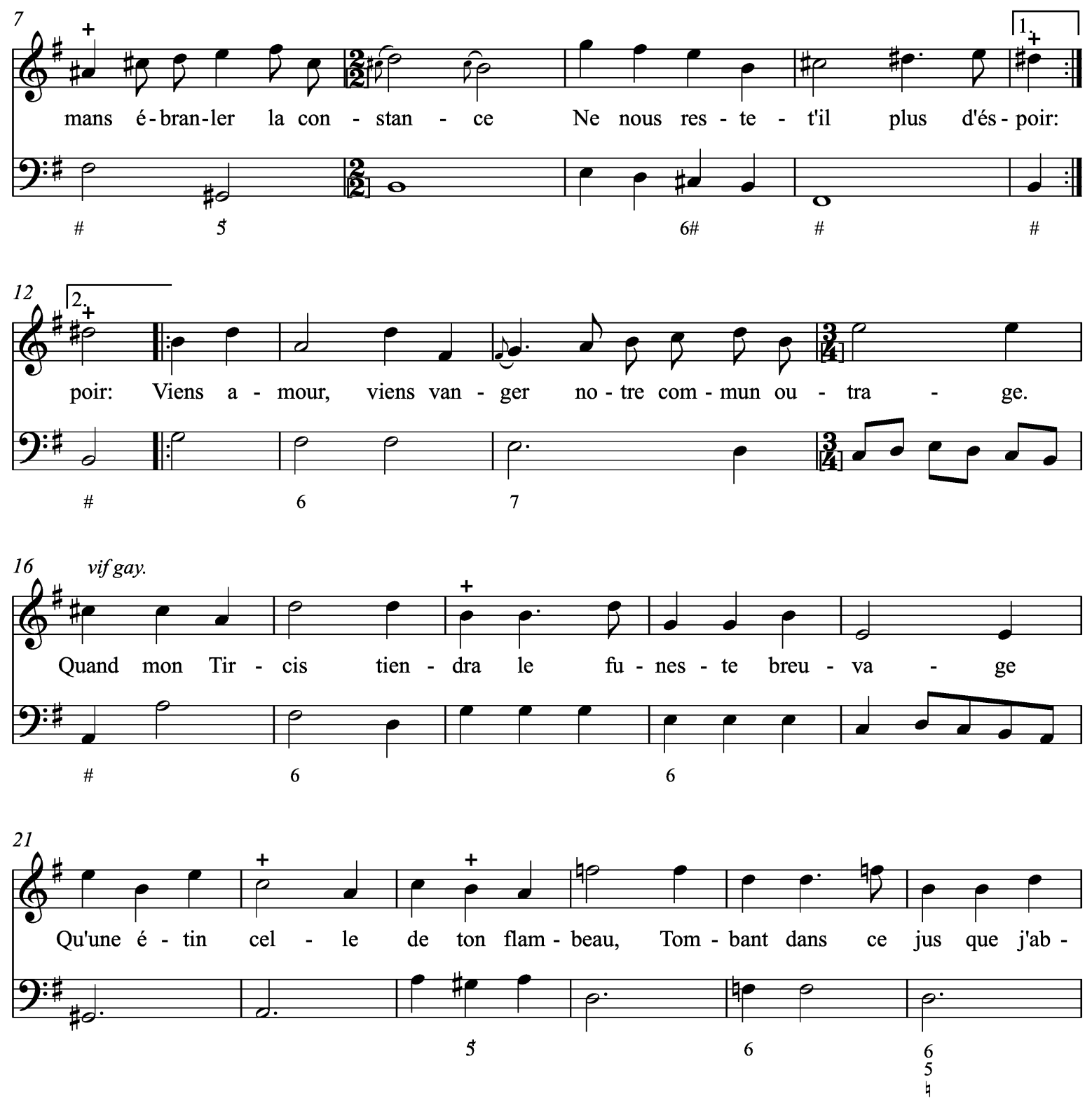

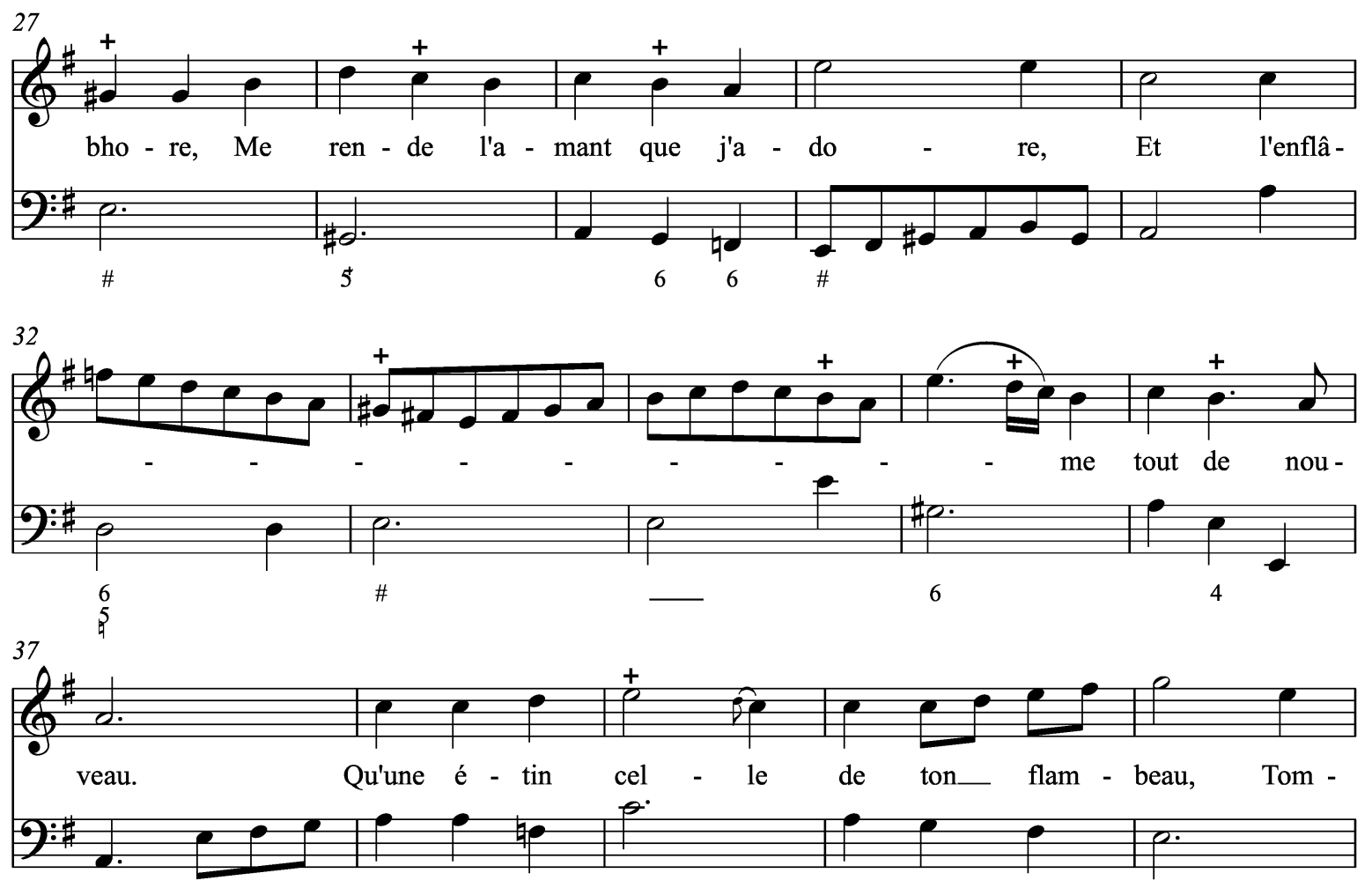

$6 \#$
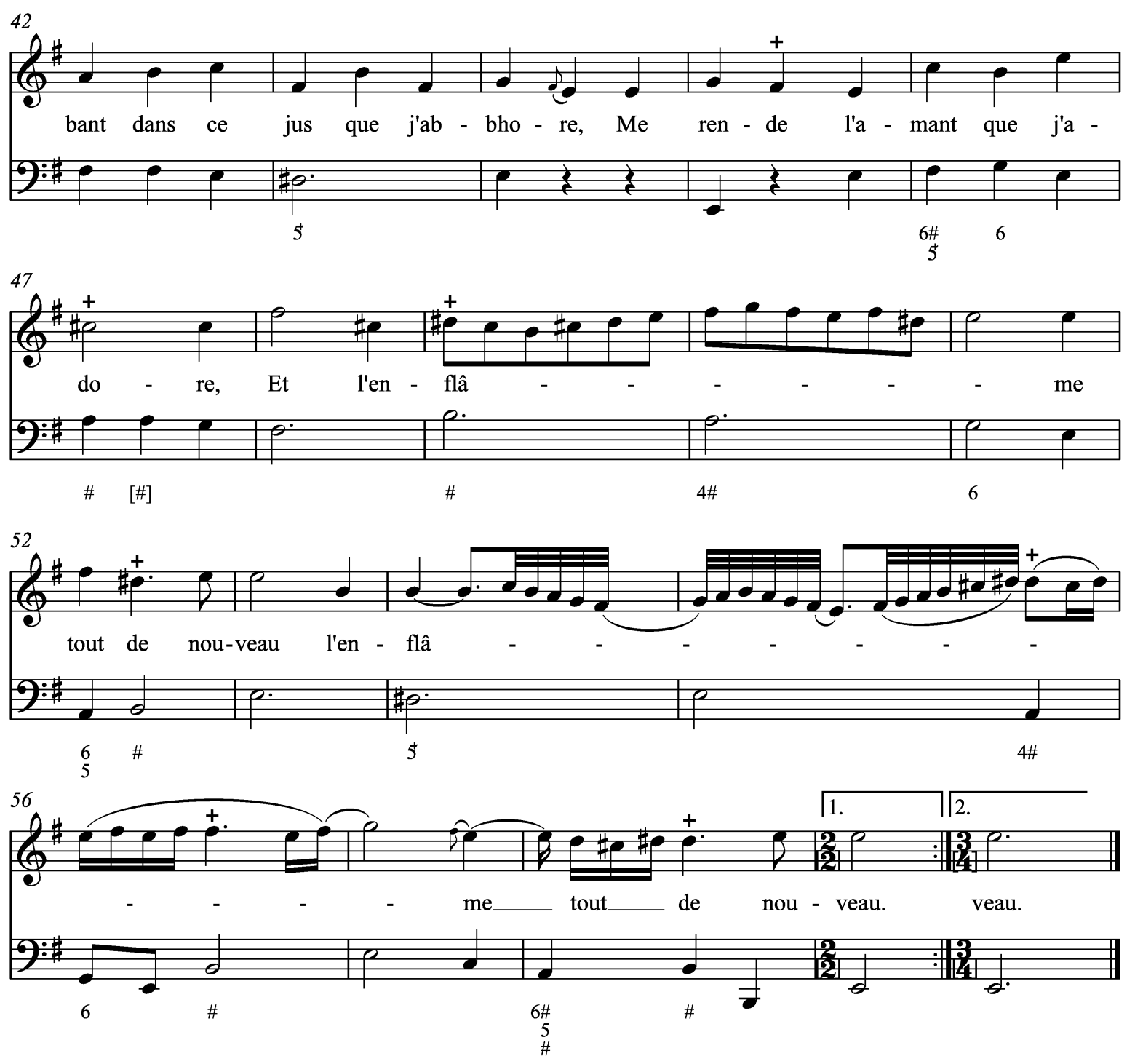


\section{Ah que l'homme est sçavant}

Récit de basse

[Voix]

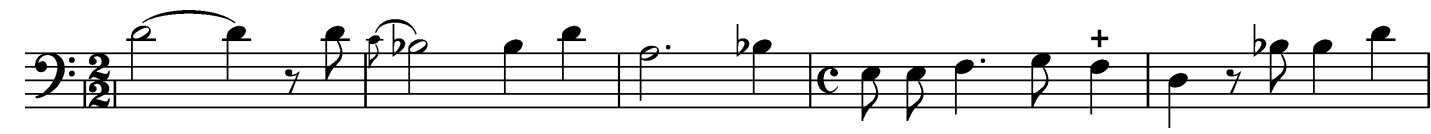

Ah__ quel'homme est sça - vant,

di - soit unjour Gré-goi - re, Et que son

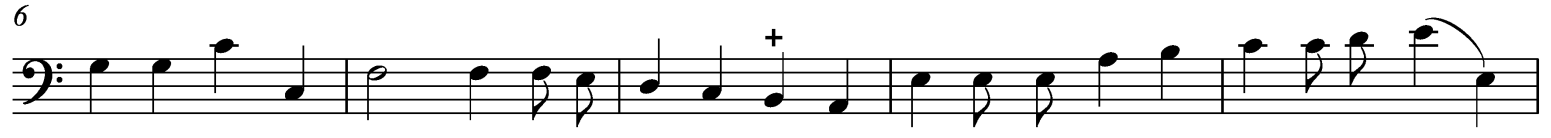

sort me sem-ble beau quand je le vois Sur un-four-neau tra-vail-ler sui - vant un gri- moi -

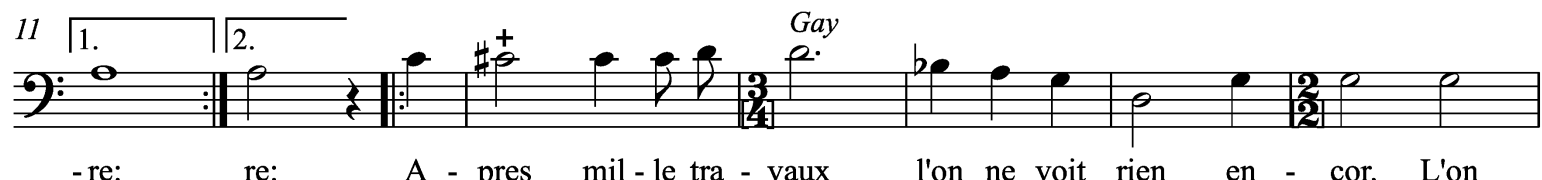

-re: $\quad$ re: $\quad$ A - pres mil - le tra - vaux l'on ne voit rien en - cor. L'on

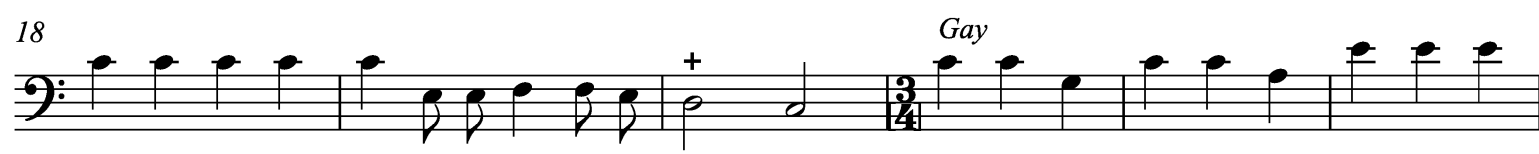

fi - xe le mer-cure, on a beau me le di - re, Dans un creu - set je vois met-tre de

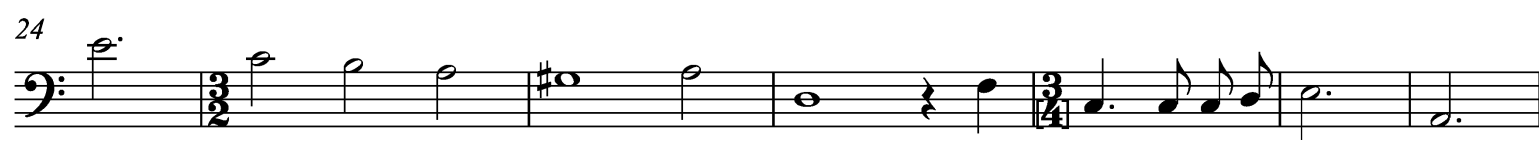

l'or, Et de sou - fleur con - fus ja - mais nel'enre - ti - re
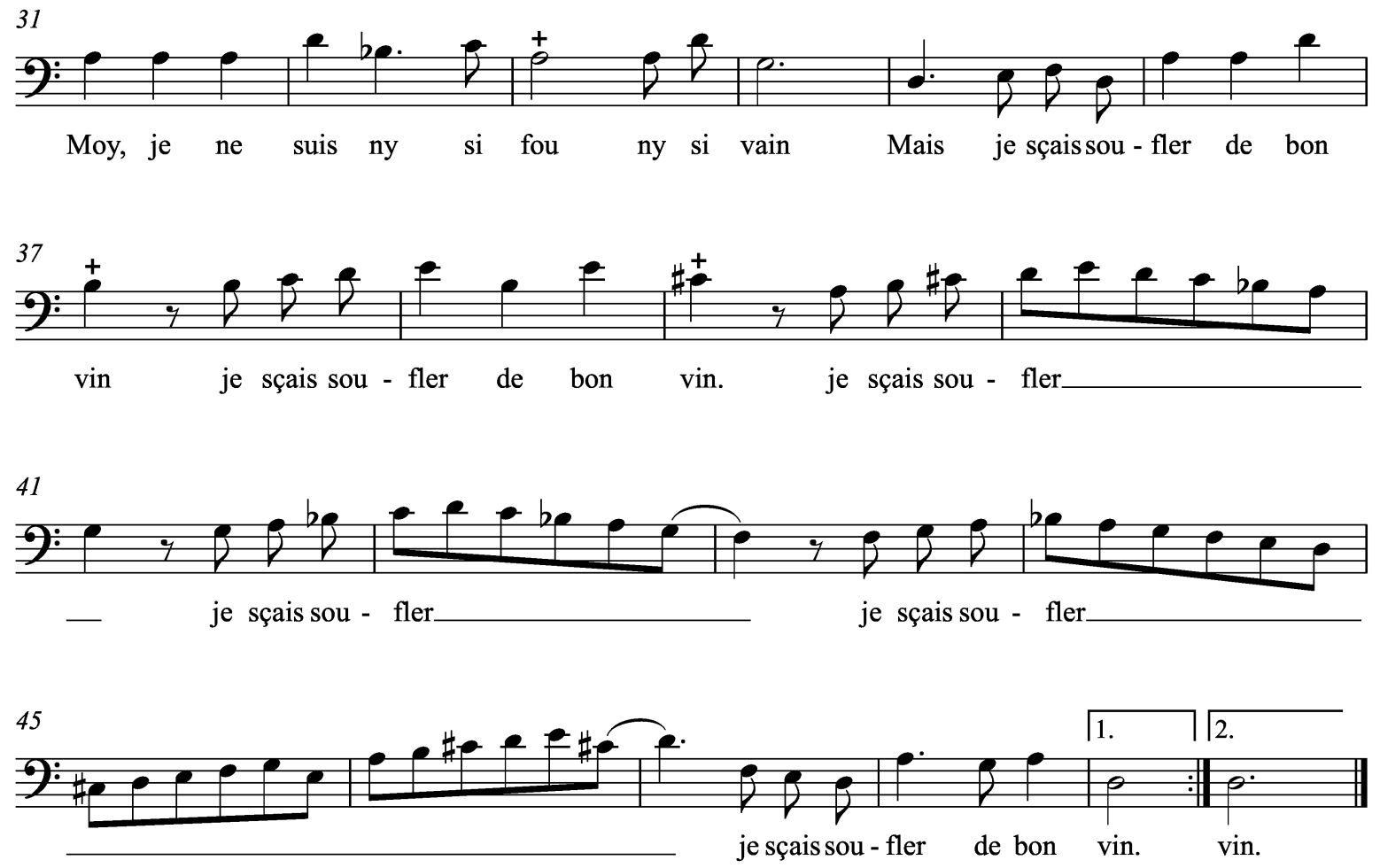


\section{L'autre jour pres d'un bosquet}

\section{Chansonette anacreontique}

Vaudeville: Air à boire
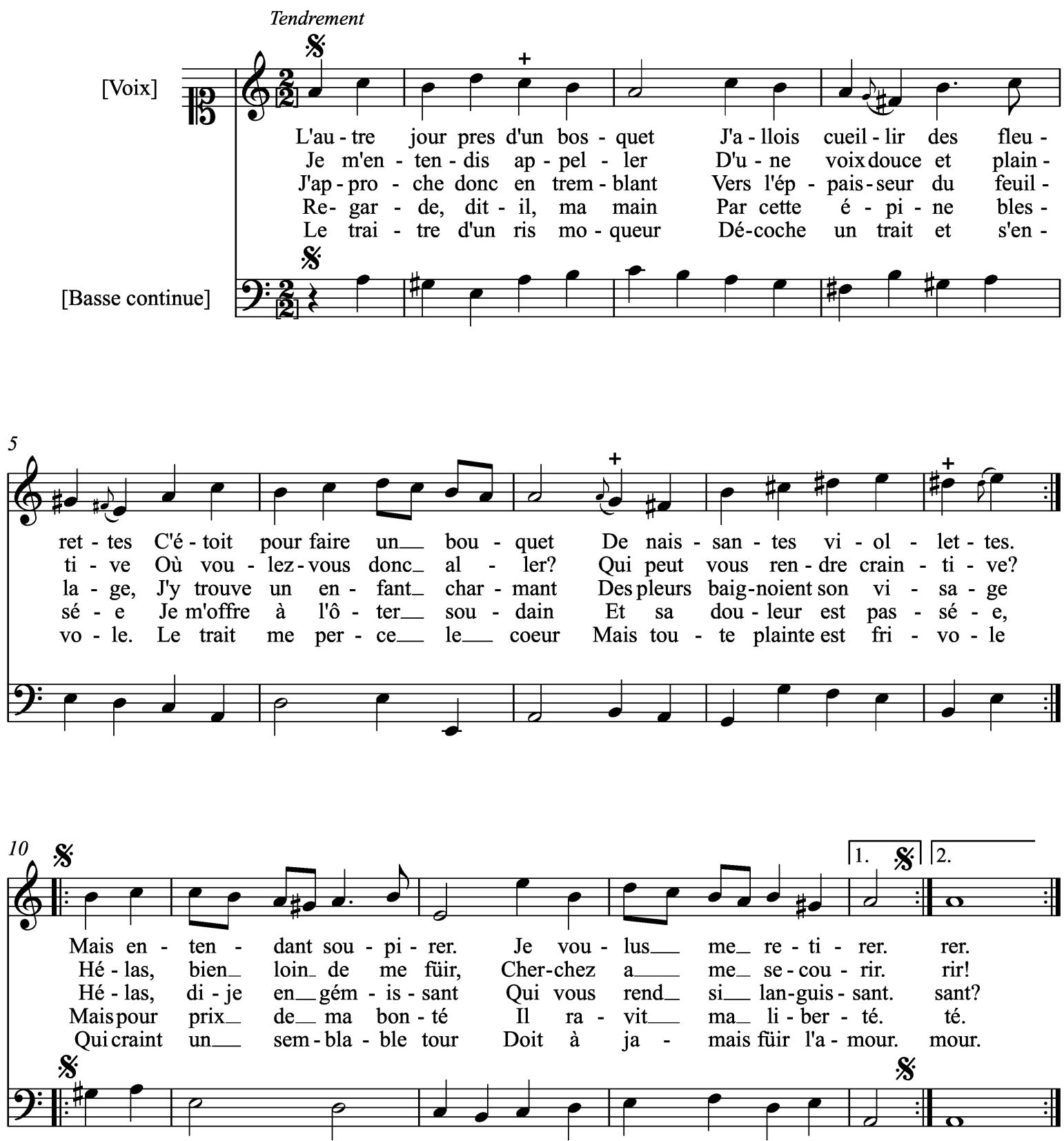